Historic, Archive Document

Do not assume content reflects current scientific knowledge, policies, or practices. 


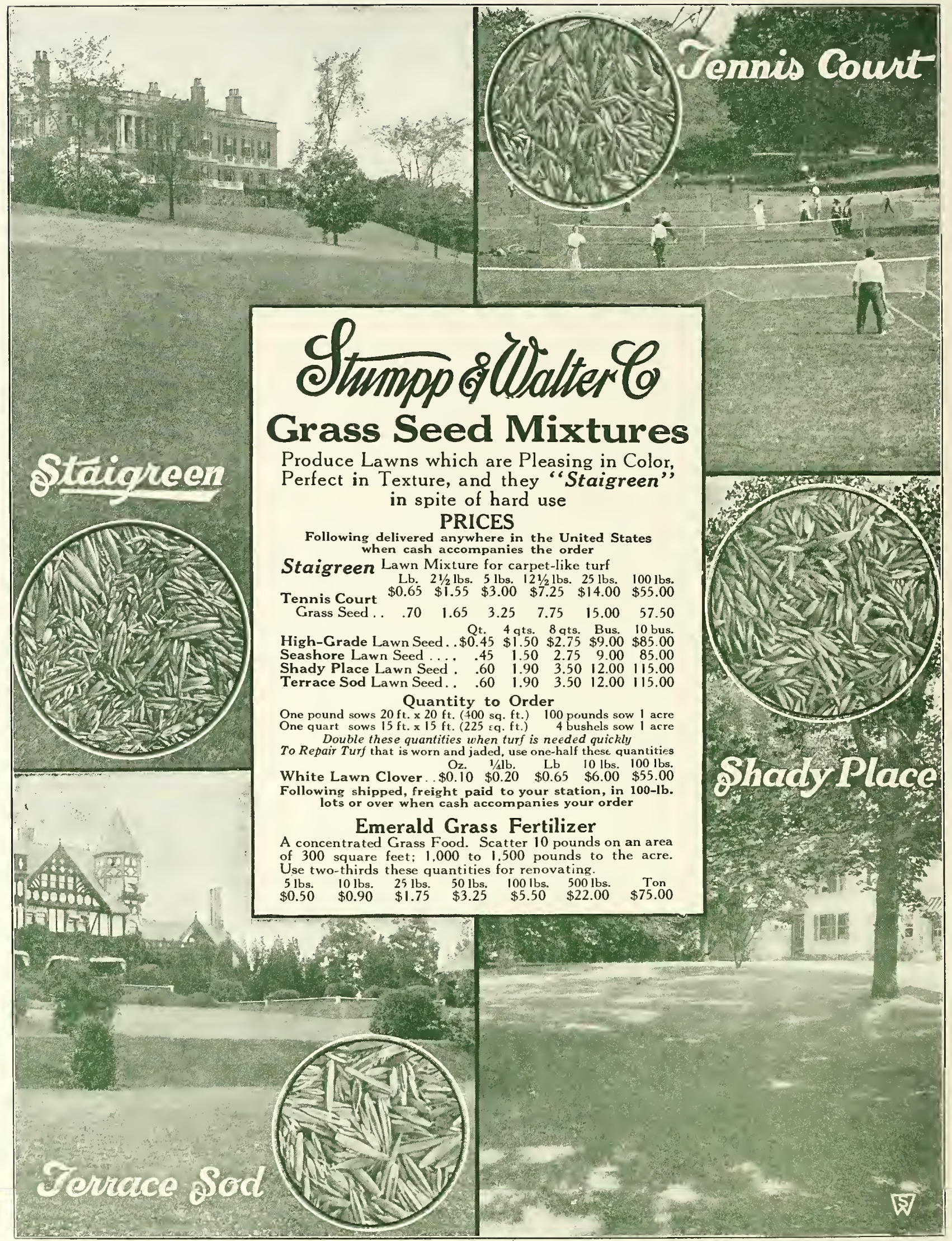




\title{
A PACKAGE OF SEEDS
}

\author{
From the Book, "The Light of Faith"
}

By EDGAR A. GUEST

Copyright I926, The Reilly \& Lee Co.

I paid a dime for a package of seeds

And the clerk tossed them out with a flip.

"We've got 'em assorted for every man's needs,"

He said with a smile on bis lip.

"Pansies and Poppies and Asters and Peas!

Ten cents a package! And pick as you please!"

Now seeds are just dimes to the man in the store,

And the dimes are the things that be needs;

And I've been to buy them in seasons before,

But have thought of them merely as seeds;

But it flashed through my mind as I took them this time,

"You bave purchased a miracle bere for a dime!"

“You've a dime's worth of power which no man can create,

You've a dime's worth of life in your hand!

You've a dime's worth of mystery, destiny, fate,

Which the wisest cannot understand.

In this bright little package, now isn't it odd?

You've a dime's worth of something known only to God!"

These are seeds, but the plants and the blossoms are bere

With their petals of various bues;

In these little pellets, so dry and so queer,

There is power which no chemist can fuse.

Here is one of God's miracles soon to unfold,

Thus for ten cents an ounce is Divinity sold!

Seeds of hundreds of delicious vegetables and beautiful flowers are offered in this catalogue at io cents the package; others, more difficult to produce, cost more.

Irrespective of price, however, all are grown with the most meticulous care, so thoroughly tested that we believe them to be the best procurable.

January $I, 1929$.

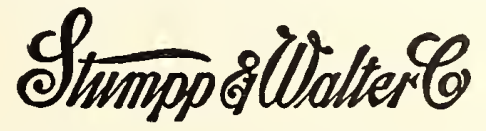




\section{Stumpp \& Walter Co.'s Vegetable Seeds}

It has always been our endeavor to list only such sorts of Vegetable Seeds as, from our tests, we have found to be of superior merit; and, while we have in many instances not listed certain varieties, which have been struck out on account of being out of date, we have in every instance listed a superior sort which we can recommend as being more satisfactory both for the market and the home-garden.

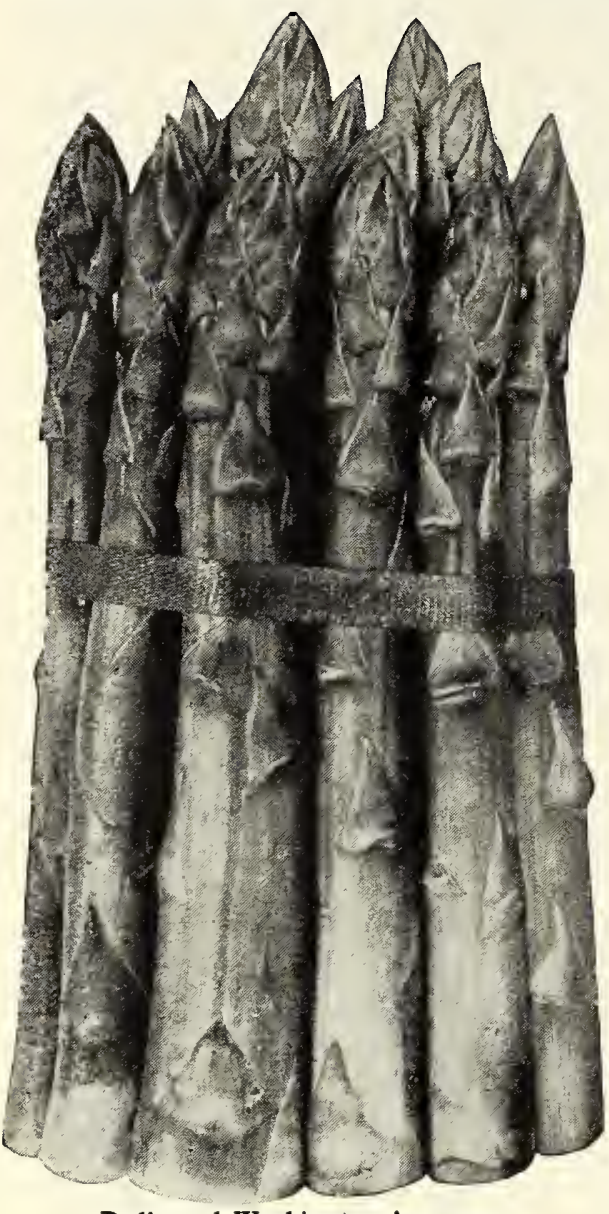

Pedigreed Washington Asparagus

\section{ASPARAGUS ROOTS}

Culture.-Dig a trench, I $1 / 2$ feet deep and $\mathrm{I}$ foot wide, and fill in about 4 inches with wellrotted manure, tread down firmly. On this put about 5 inches of good, rich soil, and then lay the roots in, about I 8 inches apart, taking care to spread well, having the crown in an upright position. Cover to within 4 inches of the top of the trench and, as the plants grow, gradually fill the trench to the surface. For spacing between the rows allow I 8 inches.

PEDIGREED WASHINGTON. Originally developed by the U. S. Department of Agriculture, further selected and improved. It is rust-resistant, particularly vigorous, and of wonderful quality. The shoots are large, straight, dark green in color and with a heavy purple over-tone; the tight, firm tips do not begin to open out until well out of the ground. Pedigreed Washington Asparagus stands ahead of all other varieties as a standard for the home or marketgarden. Extra-choice Roots, $\$ 4.50$, per Ioo, $\$ 40$ per I,00o.

\section{CONOVER'S COLOSSAL.}

Mammoth Roots .............\$3 50 \$30 o0

\section{ASPARAGUS SEED}

One ounce will plant about 50 feet of drill

CONOVER'S COLOSSAL. A mammoth green sort of the largest size and of good quality. The best of the old kinds. Pkt. Io cts., oz. I 5 cts., 1/4lb. $40 \mathrm{cts}$., lb. \$I.

\section{LIMA BEANS}

\begin{tabular}{|c|c|}
\hline & NS \\
\hline $\begin{array}{l}1 / 2 \text { lb. equals about } 1 / 2 \text { pint } \\
1 \text { lb. equals about } 1 \text { pint }\end{array}$ & $\begin{array}{l}2 \text { lbs. equal about } 1 \text { quart } \\
15 \text { lbs. equal about } 1 \text { peck }\end{array}$ \\
\hline
\end{tabular}

\section{DWARF BUSH}

One pound will plant 50 to 100 feet of drill

If ordered alone, add $5 \mathrm{cts}$. per $1 / 2$ pound, $10 \mathrm{cts}$. per pound, and 15 cts. per 2 pounds for mailing.

FORDHOOK. A form of the popular Challenger or Potato Lima, and earlier. Both pods and Beans are almost twice the size of the Kumerle or Dreer's Bush Lima. Pods measure 4 to 5 inches, frequently containing 4 fine Beans of the finest flavor. Pkt. Ioc., $1 / 2$ lb. 3 oc., lb 5oc., 2 lbs. 9 oc., 5 lbs. $\$ 2.10,15$ lbs. $\$ 5.75$.

HENDERSON BUSH LIMA. Both pods and Beans are small, but they are produced in large quantities. The standard Lima for canning. $1 / 2 \mathrm{lb} 25$ cts., lb. $40 \mathrm{cts}$., 2 lbs. $75 \mathrm{cts}$., 5 lbs. $\$$ I. 75 , I 5 lbs. $\$ 4.75$.

NEW IMPROVED BUSH LIMA. Similar to Burpee's Bush Lima except that pods are larger in size and are well filled with larger and thicker Beans. A far greater producer; growth more vigorous; the blossombearing stalks are thrown well out of the foliage, and the Beans are ready for picking a full week earlier. $1 / 2$ lb. 25 cts., lb. 45 cts., 2 lbs. 85 cts., 5 lbs. $\$ 2$, I 5 lbs. $\$ 5.50$.

\section{LIMA BEANS (POLE) $\begin{gathered}\text { One pound will } \\ \text { plant } 50 \text { hills }\end{gathered}$}

CHALLENGER or POTATO. Early and more prolific than the large Lima; a small Bean of decidedly excellent flavor. $1 / 2$ lb. 25 cts., lb. 45 cts., 2 lbs. 85 cts., 5 lbs. $\$ 2,15$ lbs. $\$ 5.50$.

EARLY LEVIATHAN. The earliest variety of Pole Lima; produces pods in clusters. A splendid variety where the season is short. Pkt. Io cts., I/2lb. 25 cts., lb. 45 cts., 2 lbs. 85 cts., 5 lbs. $\$ 2$, I5 Ibs. $\$ 5.50$.

S. \& W. CO.'S GREEN-SEEDED. Very strong, vigorous vine with many large runners or branches, producing very many fine pods closely filled with large, broad Beans, a large proportion containing four. Much nearer to having every Bean perfect than any other Pole Lima. The green tint is a distinctive feature of this Bean, for it retains this tint in the dry state to a greater extent than usual, which indicates the fine qualities which it possesses, being fine-flavored and more tender when cooked than white-seeded Beans. $1 / 2 \mathrm{lb}$. $30 \mathrm{cts}$., lb. 55 cts., 2 lbs. $\$$ I, 5 lbs. $\$ 2.25$, I 5 Ibs. $\$ 6.25$.

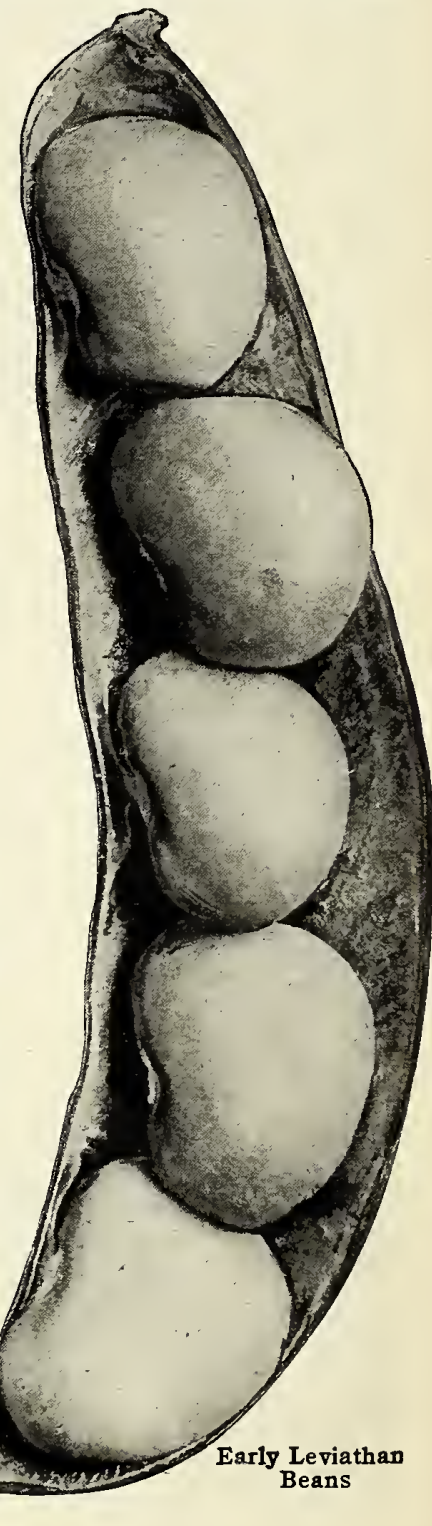




\section{DWARF or BUSH BEANS}

One pound will plant 100 feet of drill

Culture.-Plant as soon as danger of frost is over, placing the seeds 2 to 3 inches apart in drills and about $21 / 2$ inches deep. The rows should be about $21 / 2$ feet apart, and the soil slightly hilled, to insure good drainage and keep the Beans from touching the ground. Most Beans should be picked when about 4 inches long. Frequent pickings insure a more prolonged bearing season. Avoid jerking the plant, as this frequently disturbs young feeding roots. Use the finger-nails to sever the stems. Do not pick when bushes are wet, as this may cause blight and rust. For succession in the home-garden plant 30 feet of row every other week up to August I.

If ordered alone, add for mailing, 5 cts. per $1 / 2 \mathrm{lb}$., $10 \mathrm{cts}$. per $1 \mathrm{~b}$., and $15 \mathrm{cts}$. for $2 \mathrm{lbs}$.

\section{GREEN-PODDED BEANS}

BOUNTIFUL. To this Bean belongs the distinction of being one of the best flat, green-podded Bush Beans; very prolific and a contin uous bearer from early spring to late fall. It is tender and of delicious flavor. Is as entirely stringless as the breeder has leen able to make a flat, green-podded Bean. Its pods contain a little more fiber than Stringless Green-Pod of like age, but they average large and are entir ely stringless until they become longer than 5 inches. One of the earliest Bush Beans. Pkt. I 5 cts., I/2lb. 30 cts., 1 b. 50 cts., 2 lbs. 95 cts., 5 lbs. \$2.25. I 5 lbs. $\$ 6.25$.

STRINGLESS GREEN-POD. This Bean remains among the very best first-early roundpodded Bush Beans. A very free bearer; entirely stringless; averages 5 inches long and is slightly curved. A handsome sort, borne on a healthy plant which stands dry weather well. I $/ 2 \mathrm{lb}$. 25 cts., lb. 45 cts., 2 lbs. 85 cts., 5 lbs. $\$ 2$, I 5 lbs. $\$ 5.50$.

GIANT STRINGLESS GREEN-POD. Pods greatly resemble those of Stringless Green-Pod. Fully an inch longer in size and a trifle earlier. A variety that is largely grown for the market on account of its size and splendid shape. Splendid sort for succession when planted with Stringless Green. Pol. $1 / 2 \mathrm{lb}$. $30 \mathrm{cts}$., $1 \mathrm{~b}$. $50 \mathrm{cts}$., 2 lbs. $95 \mathrm{cts}, 5 \mathrm{lbs}$. $\$ 2.25$, I5 lbs. $\$ 6.25$.

BLACK VALENTINE. A Bean which has been planted extensively in the South on account of its heat-resisting qualities. Matures early, producing long, round, straight pods, which are tender when quite young. Perfects the crop all at once, hence valuable as a market sort. Pkt. Io cts., 1/2lb. 25 cts., lb. 45 cts., 2 lbs. 85 cts., 5 lbs. $\$ 2$, I 5 lbs. $\$ 5.50$.

EARLY RED VALENTINE. This variety is valuable on account of its earliness. Pods very fleshy, round and saddle-backed, with but slight strings. Bushes grow uniformly about I5 inches in height and produce a large crop. $1 / 2 \mathrm{lb}$. 25 cts., $1 \mathrm{~b} .45 \mathrm{cts} ., 2$ lbs. $85 \mathrm{cts}$., 5 lbs. $\$ 2$, I 5 lbs. $\$ 5.50$.

DWARF HORTICULTURAL. Pods are medium in length, slightly curved, and when nearly: developed are splashed with bright red on a yellow skin. The green-shelled Beans are of fair size, tender, and fine flavored. $1 / 2 \mathrm{lb}$. $25 \mathrm{c}$., lb. $45 \mathrm{c}$., 2 lbs. $85 \mathrm{c}$., $5 \mathrm{lbs}$. $\$ 2,15 \mathrm{lbs} \$ 5.5 \mathrm{o}$.

REFUGEE, or 1,000-to-1. One of the latest Beans. The pods are nearly round, light green, 5 inches long, terminating in a slender point; fleshy, brittle, and mild in favor, with but slight strings. Pkt. Io cts., I/2lb. 25 cts., lb. 45 cts., 2 lbs. 85 cts., 5 lbs. $\$ 2$, I 5 lbs. $\$ 5.50$.

\section{DWARF or BUSH WAX-PODDED BEANS}

SURE-CROP STRINGLESS WAX. The plant grows to a large size and, having a strong, thick stem, stands up well even during a long season of stormy weather, thus protecting the pods from dirt and dampness. It is very productive, bearing in great abundance large, handsome, golden yellow pods which are stringless and tender at all stages of development. Being very hardy, the seed may be planted early. Sure-Crop is more rustproof and will stand a longer season of damp, wet weather than any other Stringless Wax Bean. 1/21b. 30 cts., lb. 50 cts., 2 lbs. $90 \mathrm{cts}$., 5 lbs. $\$ 2.10$, I 5 lbs. $\$ 5 \cdot 75$.

HARDY WAX. One of the best round-podded stringless Wax Beans ever evolved. The plants have thick, leathery leaves which resist cold, blight and plant diseases to a marked degree. Within 65 or 70 days of planting,

Hardy Wax bears immense crops of slightly curved deep yellow pods. Remains in bearing for a remarkably long period. $1 / 21 \mathrm{~b}$. 35 cts., lb. 55 cts., 2 lbs. $\$$ I, 5 lbs. $\$ 2.25$, I 5 lbs. $\$ 6$. jo.

IMPROVED GOLDEN WAX. A very early variety with flat, golden pods.

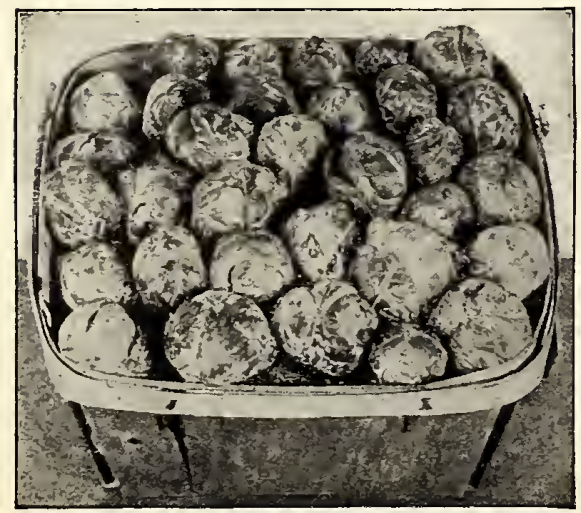

S. \& W. Co.'s Favorite Brussels Sprouts
POLE or RUNNING BEANS One pound will plant OLD HOMESTEAD (Green Kentucky Wonder). An improved sort of this well-known Bean. The pods are entirely stringless and of silvery green color, hanging in large clusters from the top to the bottom of the pole. One of the most prolific. Pkt. Io cts., 1/21b. $25 \mathrm{cts}$., lb. 45 cts., 2 lbs. 85 cts., 5 lbs. $\$ 2$, I 5 lbs. $\$ 5.50$.

GOLDEN CLUSTER WAX. The leading early Wax Pole Bean. Pods are tender and of fine flavor. Few Beans equal this as a "snap sort" while young, or as a dry, pure white shell Bean for winter use. Pkt. Io cts., 1/21b.30 cts., 1b. 50 cts., 2 lbs. 90 cts., 5 lbs. \$2.I0, I 5 lbs. $\$ 5.75$

LAZY WIFE. The best late, green-podded Pole Bean. The pods are of a medium dark green; broad, thick, very fleshy and entirely stringless. I/2lb. 25 cts., lb. 45 cts., 2 lbs. 85 cts., 5 lbs. $\$ 2$, I 5 lbs. $\$ 5.50$.

\section{BRUSSELS SPROUTS One ounce will produce}

CurturE.- - Sow in May, in shallow drills, I inch deep and I 2 inches apart. Transplant in July. When the crown, or top sprout is beginning to head, pinch it out, to admit of the whole strength being thrown into the side shoots. Very hardy. This is a delicious vegetable and should find a place in every garden; greatly improved by first frosts.

S. \& W. CO.'S FAVORITE. New. Semi-dwarf, thickly covered with sprouts by the end of September; excellent. Pkt. 20 cts., oz. \$I, 1/4lb. $\$ 3.50$. 


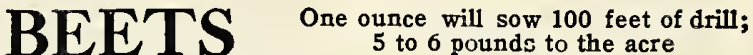

CULTURE.-Seed should be sown the latter part of April. The ground should be spaded well and deep, placing rows about 18 inches apart, and the drills $\mathrm{I}$ inch deep. Cover the seed carefully and firm in the ground by walking over the drills. When seedlings appear about 3 inches above iground, thin out to about 4 inches between the plants so as to give ample room for the proper development of the bulbs. Beets are best for pulling when about 2 inches in size. Successive sowings may be made up to the middle of July.

\section{ROUND TYPES}

CROSBY'S ORIGINAL EG YPTIAN. One of the most widely grown turnip-shaped

Beets in cultivation today. Will produce Beets ready for pulling within two or three days after Eclipse. The smooth, dark red roots are topped with light green foliage, which is prominently speckled with dark red. The flesh is carmine, handsomely marked with white zones, very tender and of uniformly sweet quality. Pkt. Io cts., oz. 20 cts., 1/4lb. 55 cts., 1b. \$r.5o.

EARLY WONDER. A variety which has gained wide popularity among market-gardeners, and one which the amateur may also grow with every confidence. It may be sown early, and it matures very rapidly. It is so uniform in growth that the crop can be lifted practically at one time, yielding the land early and quickly for the second crop. The root is nearly globular in shape, slightly flattened. The leaves are of medium size, and the color of the flesh is deep blood red. Pkt. I5 cts., oz. 35 cts., I/4lb. $\$ 1,1 b . \$ 3$.

DETROIT DARK RED. Extended experience has shown that this Beet comes nearer the ideal than any other, and where but one variety is used this should be the first choice. The round, dark red globe roots are uniformly smooth. The flesh of the very young Beets is almost black-red, turning to dark crimson with dark purple zones as the Beets grow larger. When cooked, the Beets are of an appetizing dark red and very sweet. Pkt. Io cts., oz. 25 cts., $1 / 4 \mathrm{lb}$. 65 cts., 1b. $\$ 1.75$.

S. \& W. CO.'S WINTER KEEPER. A distinct strain of a main-crop, globe-shaped Beet produced by many years of painstaking selection on the part of a grower who takes particular pride in striving after high ideals in seed selection. Two leading characteristics make this Beet worthy of any gardener's time and space: the uniformly excellent flavor of its flesh at all stages of development and the remarkable manner in which this quality is preserved during winter storage. Beets are almost globe-shaped, tapering somewhat toward the root. The flesh is dark red, sweet and tender at all stages of growth regardless of size. They may be stored in a cellar or pit until the spring, and will cook more tender and sweet than ordinary varieties will when taken from the garden. Pkt. $20 \mathrm{cts}$., $02.65 \mathrm{cts}$., $1 / 4 \mathrm{lb}$. $\$ 1.75,1 \mathrm{~b} . \$ 5$.

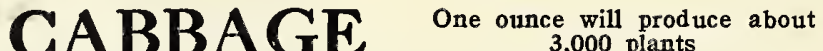

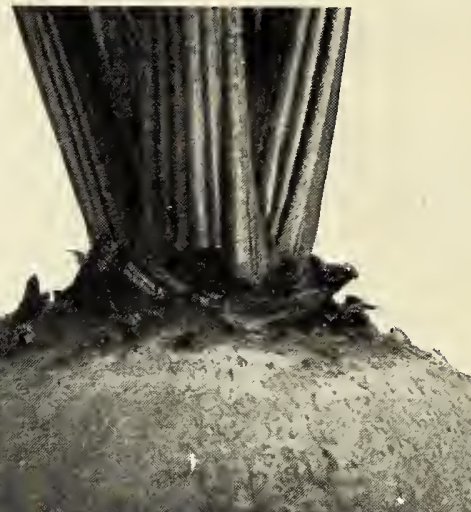

CULTURE.-Sow early kinds in hotbeds in February and March, and in the open ground during April and May. Late varieties for fall and winter use should also be sown in May. Early sorts may be planted in rows 2 feet apart, with 20 inches between plants in the row; late kinds
should stand at least 2 feet each way. To be well grown, Cabbages require a deep, rich,

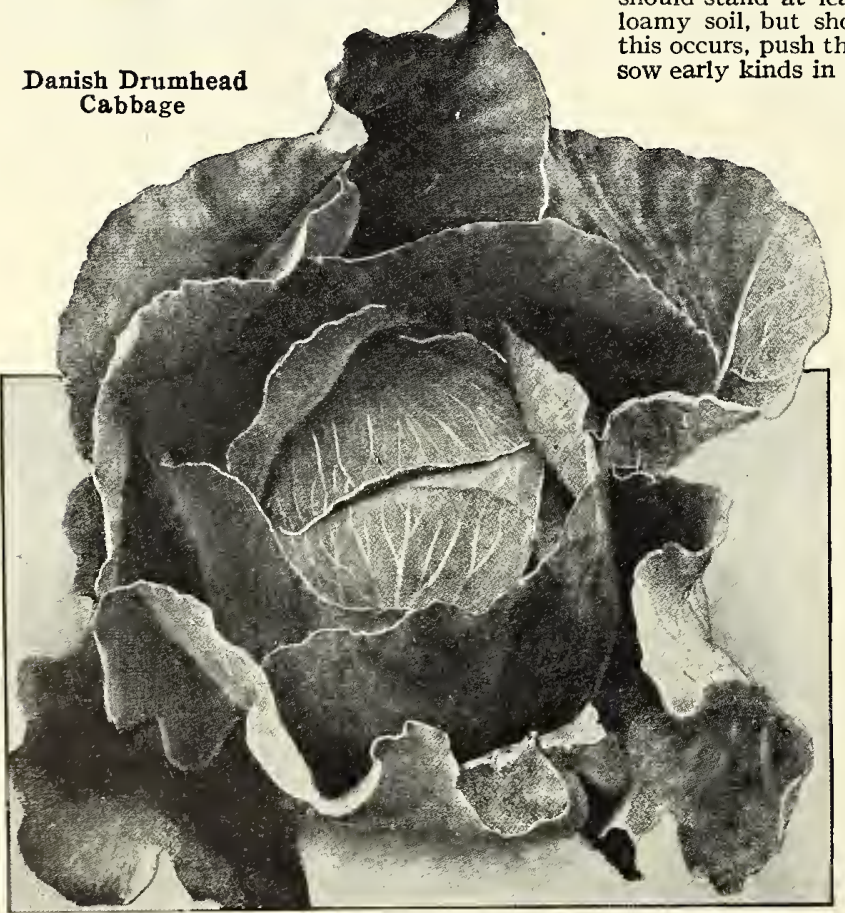

Club Root in Cabbages. As a protection against this conClub Root in Cabbages. dition, we advise steeping $\mathrm{Cab}$ bage seed for twenty minutes in one ounce of formaldehyde diluted with 2 gallons of water. Wash in clear water and spread in the air to dry.

EARLY FLAT DUTCH. Very reliable, and the favorite of many Baltimore growers. The heads are round, flattened, and solid; the stem is short. Matures about ten days later than Copenhagen Market. Pkt. I5 cts., I/20z. 35 cts., oz. 60 cts., I/4lb. $\$ 2$.

COPENHAGEN MARKET. The best of al early Cabbages. Stands longer without bursting than other early sorts. This new extraearly variety, ripening with Charleston Wakefield, also originated in Denmark, and is as good, in its class, as the old favorite Danish Ballhead. The stem is short, the head round and solid. When ready for cutting, Copenhagen Market is the heaviest of the extraearly varieties, and if left until fully mature, frequently weighs 8 to ro pounds. A leader for the home-garden and market. Pkt. I5 cts., 1/40z. 40 cts., $1 / 2 \mathrm{Oz}$. $60 \mathrm{cts}$., oz. $\$ \mathrm{I}, 1 / 4 \mathrm{lb}$. $\$ 3.50$.

IMPROVED EARLY JERSEY WAKEFIELD. While this variety is not quite so early as S. \& W. Co.'s Famous Early Conical, it has been long considered as the best early conical-type Cabbage which we have. The heads are hard and solid with just a few outside leaves, which are unusually thick, enabling them to stand cold weather when wintered in coldframe. Pkt. Io cts., 1/20z. $30 \mathrm{cts}$., oz. 55 cts., 1/4lb. \$I.5O.

DANISH DRUMHEAD. Averages much larger size than the Ballhead; is about two weeks earlier; fine-grained and sweet-flavored; the best Cabbage for winter use. Pkt. I 5 cts., $1 / 4 \mathrm{Oz}$. $40 \mathrm{cts}$., $1 / 2 \mathrm{Oz}$. 60 cts., oz. $\$ \mathrm{I}, \mathrm{I} / 4 \mathrm{lb}$. $\$ 3.50$. 


\section{GABBAGE, continued}

LARGE LATE FLAT DUTCH. One of the most reliable in cultivation for winter use; produces immense heads of the finest quality; splendid keeper. Pkt. Io cts., 1/20z. $30 \mathrm{cts}$., oz. $55 \mathrm{cts}$., 1/41b. $\$ 1.50$.

MAMMOTH ROCK RED. This is by far the best, largest and surest-heading Red Cabbage ever introduced. The plant is handsome, with numerous spreading leaves. The head is large, round, very solid. Pkt. I 5 cts., $1 / 40 z$. 40 cts., $1 / 20 z$. $60 \mathrm{cts}$., Oz. \$I, I/41b. \$3.50.

AMERICAN DRUMHEAD SAVOY. None of the late-growing varieties can begin to equal in flavor this sort for family use; heads large. Pkt. I5 cts., $1 / 20 z$. 60 cts., oz. \$ I, $1 / 41 \mathrm{~b}$. \$2.75.

PE-TSAI, CHINESE or "CELER Y" CABBAGE. Pe-Tsai produces beautiful, crisp, celery-like heads that somewhat resemble Cos lettuce. Pkt. I5 cts., I/20z. $30 \mathrm{cts}$., oz. $55 \mathrm{cts}$., $1 / 4 \mathrm{lb}$. $\$ \mathrm{I} .50$.

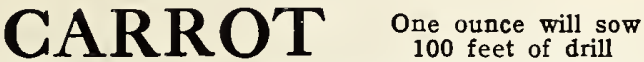

Culture.- To produce the finest crop, the land should be thoroughly manured the previous season; forked roots will result if the seed is sown on freshly manured soil. Sow the early sorts in March and April, in drills $\mathrm{I}$ inch deep and I4 inches apart; thin out to 4 inches. For main crop sow in May or beginning of June. Care should be taken, at all times, to see that soil is firm over the seeds, either by means of the feet, roller, or garden drill.

SELECTED CHANTENAY. A very splendid type of the half-long, stump-rooted Carrot. Averages $5^{1 / 2}$ to 6 inches in length, broad at the neck, narrowing gradually to a blunt end. The flesh is rich orange-red. free from core, tender, fine flavored, and of excellent table quality. Pkt. Io cts., oz. $30 \mathrm{cts}$., 1/4lb. $75 \mathrm{cts}$., lb. $\$ 2$.

EARLY SCARLET HORN. Favorite for early crop but not large. Considered a good general-purpose all-season variety since, sown late in the season, the roots are firm enough for winter storage. Sometimes used for forcing. Pkt. I 5 cts., oz. 35 cts., 1/41b. 90 cts., lb. $\$ 2.50$.

SELECTED DANVERS. A handsome, cylindrical-shaped Carrot of good size and stump-rooted. It is of a rich, dark orange color, grows to large size, is smooth, and has little core. It is a first-class Carrot for all soils, yields a greater weight per acre than any other variety, and is more easily harvested than the old long varieties. This selected stock we are now offering has been specially grown for market-gardeners and is sure to give satisfaction. Pkt. Io cts., oz. $30 \mathrm{cts}$., $1 / 4 \mathrm{lb}$. $75 \mathrm{cts}$., lb. $\$ 2$.

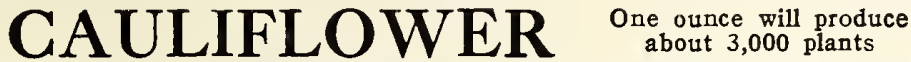

Culture.- Sow the first week in May and prick out on a rich piece of ground; transplant in July. For wintering under glass sow in the second and last weeks in September; transplant thickly into a cold pit or frame; give plenty of air in mild weather, and cover up well when conditions are severe. Again sow in February in a hotbed and transplant in April. For Cauliflower the ground should be well prepared by trenching, incorporating at the same time a good share of rotten manure. Select new ground, if possible, as Cauliflower rarely succeeds on soil which has been cropped year after year with other kinds of vegetables. Plant in rows 20 inches apart and 2 feet between the rows. To be successful with this vegetable, rich soil and abundant moisture at all stages of development are absolutely essential. Cauliflower does not form solid heads in hot, dry climates.

EARLY SNOWBALL. This wonderful, sure-heading variety is of characteristic dwarf habit, the outer leaves being small, hence it is particularly adapted to growing under glass during winter and spring. Snowball is the most popular Cauliflower grown in America today, and the S. \& W. strain is used so largely by commercial growers because of the solidity and purity of its head, its large size, and its uniform reliability. Pkt. 20 cts., $1 / 80 z$. $70 \mathrm{cts}$., $1 / 40 z$. \$1.25, $1 / 20 z$. \$2.25, oz. \$4.

\section{CELERY One ource wiun produce}

Culture.- Sow the seed in a coldframe or dry border as early as the ground can be worked, in drills 8 to Io inches apart, covering the seed $1 / 4$ inch deep. When fairly out of the seed-leaf, they may be transplanted to another bed or thinned out to 5 or 6 inches apart, and allowed to grow until wanted for transplanting out into the beds or trenches. Early in July is the proper time to set out plants in the trenches, or as soon after early July as possible. Rows or double rows should be 3 feet apart and the plants set about 8 inches apart in the row. As the plants grow, they should be earthed up to blanch them, care being taken not to let the earth get into the heart of the plant. For keeping over the winter, they can be banked up with earth and covered over with litter to protect from frost where they have grown, placing boards on top to keep out the rain.

NEW EASY-BLANCHING. The easiest of all Celeries to blanch and as good a keeper as any late sort, though quite an early sort to mature. The flesh is crisp and brittle, the flavor particularly attractive. New Easy-Blanching combines ease of cultivation, early maturity, high quality and good keeping properties. Originator's stock. Pkt. $25 \mathrm{cts}$., 1/40z. $75 \mathrm{cts} ., 1 / 20 z . \$ 1.25,0 z . \$ 2,1 / 41 \mathrm{~b}$. $\$ 6.50$.

PARIS GOLDEN SELF-BLANCHING. (Grown in France by the originator.) This strain of Celery somewhat resembles the White Plume variety, but is much superior. It is entirely free from the green type and does not grow soft or pithy as most strains of Self-Blanching do. Rich golden yellow, solid, and a splendid Celery for family or market-gardeners' use. Pkt. $25 \mathrm{cts}$., $1 / 2 \mathrm{Oz}$. $\$ \mathrm{I}, \mathrm{0z}$. $\$ \mathrm{I} .75,1 / 4 \mathrm{lb}$. $\$ 5$.

IMPROVED WHITE PLUME. One of the most popular, because it is not necessary to bank up as with other Celeries. It is tender and of the very best flavor. Pkt. $20 \mathrm{cts}$., $1 / 20 \mathrm{Oz}$. $60 \mathrm{cts}$., Oz. $\$ \mathrm{I}, 1 / 4 \mathrm{lb} . \$ 2.75$.

CELERIAC, LARGE SMOOTH. A variety of celery with turnip-shaped roots, which are white fleshed, tender and possess the flavor of celery stalks. Pkt. I 5 cts., oz. $55 \mathrm{cts}$., $5 / 4 \mathrm{lb}$. $\$ \mathrm{I} .5 \mathrm{O}, \mathrm{lb} . \$ 4$.

\section{CHICORY}

Chicory is cultivated chiefly for its roots. The leaves, when blanched, make an excellent salad.

LARGE-ROOTED MAGDEBURG. The young leaves are used for salad, and the roots when dried, roasted and ground are used for adulterating coffee. Pkt. $15 \mathrm{cts}$., oz. $45 \mathrm{cts.,}$ 1/4lb. \$r.30, lb. \$3.50.

WITLOOF. Known in restaurants as "French Endive." Valuable as a salad as well as a vegetable. Pkt. I5 cts., oz. $45 \mathrm{cts} ., 1 / 4 \mathrm{lb}$. $\$$ I.30, lb. $\$ 3.50$.

\section{CORN SALAD One ounce will plant} LARGE-SEEDED, LARGE-LEAVED. A delicious salad for late fall, winter, and early spring use. The leaves are also used for garnishing meat dishes. Sow the seed, during July, August, and September, in rich soil in shallow drills, and cover with $1 / 4$ inch of soil. Matures in sixty to sixty-five days. The frost makes leaves tender; they can be cut and used any time during the winter and early spring. Serve with a French dressing. Pkt. Io cts., oz. $30 \mathrm{cts.}$., 1/4lb. 75 cts., lb. $\$ 2$. 


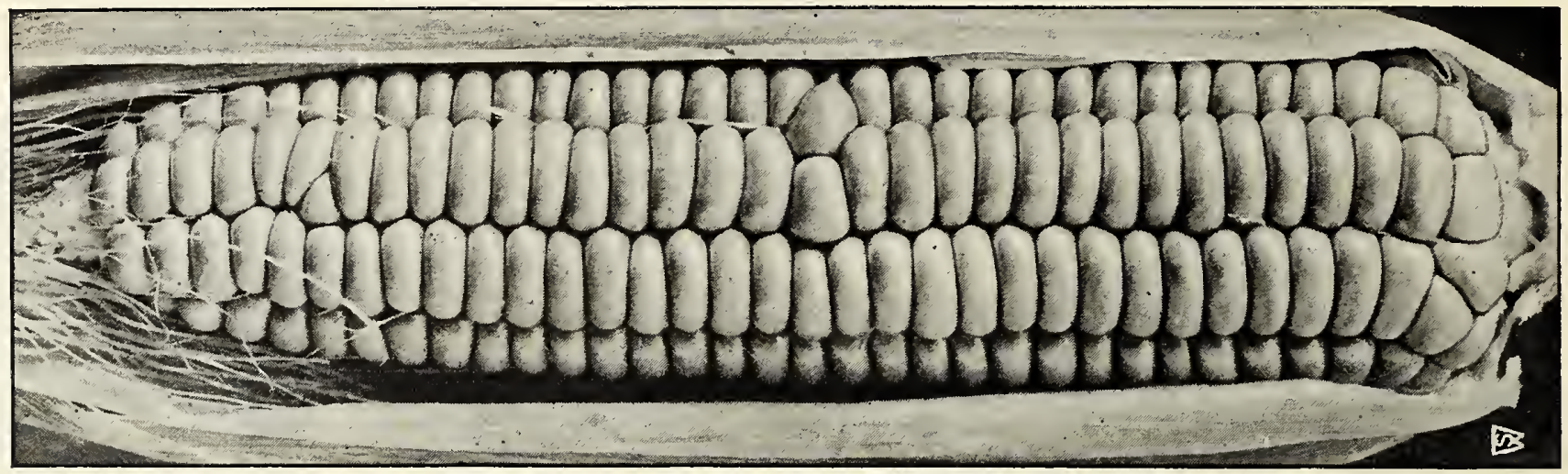

Golden Bantam. The standard for quality by which others are judged

\section{SUGAR GOR N}

One pound will plant 200 feet of drill or 200 to 300 hills
NOTE.-The American Seed Trade generally has adopted the cental system of pricing Corn, Beans, and Peas. We therefore offer by weight instead of measure. One pound of Corn is equal to about $1 \frac{1 / 2}{2}$ pints; 2 pounds to about $1 \frac{1 / 2}{2}$ quarts; the average weight of a bushel of Sweet Corn is 45 pounds.

CulturE.-Plant for succession of crops every three weeks, from April to July, in hills 3 feet apart each way, and six seeds in a hill: cover about half an inch; thin out to three plants. If ordered alone, add for mailing, $5 \mathrm{cts}$. per $1 / 2 \mathrm{lb}$., $10 \mathrm{cts}$. per lb., $15 \mathrm{cts}$. per $2 \mathrm{lbs}$.

GOLDEN BANTAM. Perhaps the sweetest Corn grown; the standard for quality by which others are judged. Plant attains a height of only 3 to 4 feet, usually bearing two or more ears to the stalk. The ears are compactly filled with kernels which when ready for the table are cream-yellow. Golden Bantam is one of the hardiest varieties of Corn grown, therefore it can be planted with safety earlier than other varieties. This characteristic also adapts it to localities having cool summer weather, a continuous supply being maintained by successive plantings. (See illustration of a typical ear.) Pkt. Ioc., 1/2lb. 25 c., lb. 45 c., 2 lbs. 85 c., 5 lbs. $\$ 2$, I 5 lbs. $\$ 5.5^{\circ}$.

METROPOLITAN. Combines the three essentials of a good Sugar Corn, namely, earliness, productiveness, and unusually superior flavor. The Io-rowed ears are 8 to 9 inches long and they are crowded with tender, melting grains. In our opinion the best early white Corn. 1/2lb. 25 cts., lb. 45 cts., 2 lbs. 85 cts., 5 lbs. $\$ 2$, I5 lbs. $\$ 5 \cdot 50$.
COUNTRY GENTLEMAN. Retains its delicate flavor and tenderness even when a little old, as the ears are encased in a heavy husk, which tends to keep the ear "in the milk" for several days longer than other varieties. The cob is unusually small and the pearly white kernels of great depth. Pkt. I0 cts., $1 / 2 \mathrm{lb} .25 \mathrm{cts}$., lb. $40 \mathrm{cts}$., 2 lbs. 75 cts., 5 lbs. $\$ 1.75$, I 5 lbs. $\$ 4.75$.

STOWELL'S EVERGREEN. Now recognized everywhere as a standard variety, both for home use and market, and is the general favorite. The ears are of large size. grains deep, exceptionally tender and sugary, and have the advantage of remaining longer in the green state than any other. Our stock has been carefully grown and selected to avoid the tendency to a shorter grain and deterioration in the evergreen character of this best of all late sorts. Pkt. Io cts., $1 / 2 \mathrm{lb}$. 25 cts., lb. 40 cts., 2 lbs. 75 cts., 5 lbs. $\$ 1.75$, 15 lbs. $\$ 4.75$.

BLACK MEXICAN. Very sweet; grains black. $1 / 2 \mathrm{lb} .25 \mathrm{cts} ., \mathrm{lb}$. 40 cts., 2 lbs. 75 cts., 5 lbs. \$I. 75 , I5 lbs. $\$ 4.75$.

\begin{abstract}
GOLDEN WEDDING CORN. A fine new sort, yielding two, and sometimes three, ears to each plant. It is a
yellow variety, like Golden Bantam, but the ears are much larger and have I2 or more rows instead of the 8
rows of Golden Bantam. For sweetness and general refinement of flavor we consider it superior to the old
Golden Bantam, and it is being served by many feading New York hotels. Pkt. 20 cts., I/2lb. $35 \mathrm{cts}$., lb. 60 cts., 2 lbs. $\$$ I. Io, 5 lbs. $\$ 2.50$.
\end{abstract}

\section{CHERVIL, MOSS GURLED One ounce will sow 150 feet of row}

Cultivation same as parsley. The young, aromatic leaves are used in soups and salads. Leaves are slight, bright green, crisp, curled, and very much divided. Pkt. I5 cts., oz. 35 cts., I $/ 4$ lb. 90 cts., lb. $\$ 2.50$.

\section{CRESS (Pepper Grass)}

One ounce will sow 100 feet of drill

Culture.-Sow early in the spring. The leaves are crisp, tender, and pungent in flavor. Sow at short intervals for succession, as it soon runs to seed.

CURLED or PEPPER GRASS. Pkt. Io cts., oz. $20 \mathrm{cts}$., $1 / 4 \mathrm{lb} .55 \mathrm{cts}$., $1 \mathrm{~b} . \$ 1.50$.

TRUE ERFURT WATER CRESS. Pkt. I5 cts., $1 / 20 z$. $40 \mathrm{cts} ., 0 z .65 \mathrm{cts}$., $1 / 4 \mathrm{lb} . \$ \mathrm{r} .75,1 \mathrm{~b} . \$ 5$.

\section{EGGPLANT One ounce will produce}

Culture.-One of the most delicious vegetables grown, yet it is not cultivated to the extent it would be if its superior table qualities were better known. Sow during March, in a warm hotbed in light rich soil, or fill a shallow box with a similar mixture and after sowing place in the full light of a warm window. Transplant or thin so that the young plants stand 3 inches each way or, better still, put out individually into small pots. Always keep the young plants warm and do not plant out until settled fine weather has arrived. They need to stand 2 feet apart each way when put outside where they are intended to fruit.

NEW YORK IMPROVED SPINELESS. This variety is grown more than any other and is a favorite for both market and family use. The fruit is large, round, of a rich deep purple-black. In spite of their size they are produced freely and continuously. The stems and calyx of this variety are entirely free from spines. Pkt. I5 cts., $1 / 20 z$. $50 \mathrm{cts}$., oz. $85 \mathrm{cts}$., $1 / 4 \mathrm{lb}$. $\$ 2.50$.

BLACK BEAUTY. Is very much on the style of New York, but it is darker in color and has a higher polish. It is also broader and thicker. Pkt. $20 \mathrm{cts}$., $1 / 20 z$. $60 \mathrm{cts}$., oz. $\$ \mathrm{I}, 1 / 4 \mathrm{lb} . \$ 2.75$. 

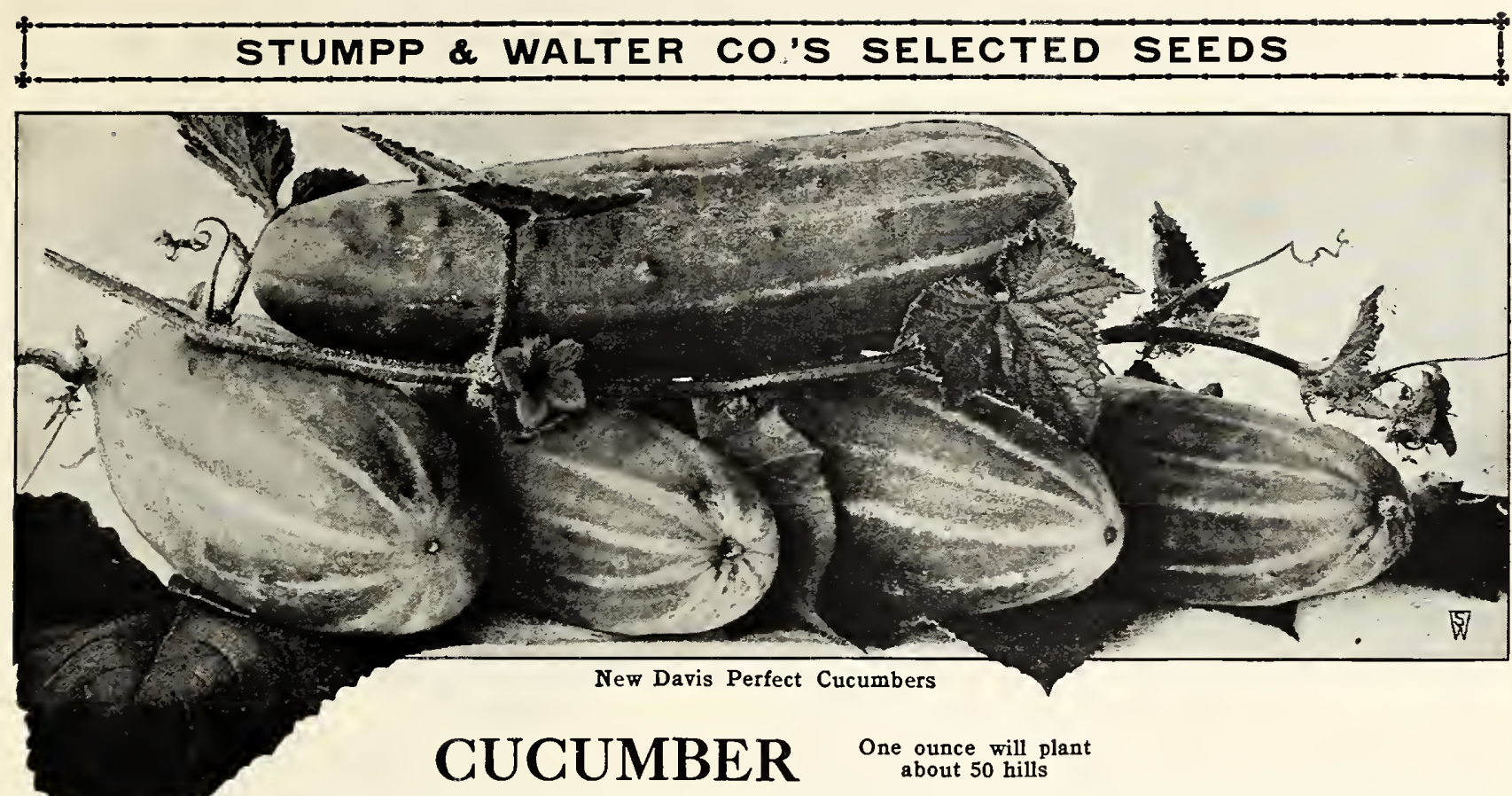

CULTURE.-The first planting should be made early in May, on partly spent hotbeds; inverted sods form an excellent medium for both planting on and carrying the young plants to their permanent location, or small paper pots can be used. Such plants are usually ready for transplanting to the open ground in from three to four weeks, and are seldom troubled with the striped bug. Transplanting, when practicable, should be done in the evening, into hills 4 feet a part each way. Thin out to about four plants to a hill when established. The seed may be planted in hills late in May, thus giving a succession. For pickles, plant during the last two weeks of June. Bug Death, or an infusion of hellebore powder in water, will destroy the striped bug.

IMPROVED EARLY WHITE SPINE. The fruits are nearly cylindrical in form, slightly pointed at the ends, perfectly smooth and of deep, rich coloring marked with distinct white lines at the blossom end. Is splendid as a table Cucumber. Pkt. Io cts., oz. 25 cts., $1 / 4$ lb. 65 cts., 1 b. $\$$ I. 75 .

EXTRA-LONG GREEN. A well-known standard variety about I foot in length, of most excellent quality, and when young makes the best of pickles. When ripe it is the best of any for sweet pickles. Vines vigorous and very productive. Our strain of this valuable sort is unsurpassed by any, being carefully selected from the best fruits. Pkt. Io cts., oz. 25 cts., I/4lb. 65 cts., lb. \$I.75.
NEW DAVIS PERFECT. In color, a dark, glossy green; shape slim and symmetrical, with an average length of Io to 12 inches. (See illustration.) Quality fine, as the seeds are very soft when fit for table use. Flesh tender and brittle, and of good flavor. Pkt. Io cts., oz. 30 cts., 1/4lb. 75 cts., lb. $\$ 2$.

FORDHOOK PICKLING. One of the best and most prolific varieties for producing pickles of medium size for both home or market use. Vines are very vigorous, yielding a large number of fruits; remaining in strong, healthy growing condition longer than any other known variety. The skin is very tender and remains so when pickled. Pkt. Io cts.. oz. $30 \mathrm{cts}$., I/4lb. $75 \mathrm{cts}$., lb. $\$ 2$.

\section{DANDELION One ounce will sow about}

Culture.- Sow early in the year in drills I foot apart, covering the seed no more than $1 / 4$ inch. Thin the plants to stand 4 inches apart. Dandelion may be blanched like endive, for salad purposes, or it may be sown later in the season, plants covered lightly with salt hay, and the following spring they will be fit for use as early greens. FRENCH GARDEN. Pkt. Io cts., 1/20z. 35 cts., oz. $60 \mathrm{cts}$., 1/4lb. \$1.75.

\section{ENDIVE One ounce will sow}

CULtURE.-One of the most attractive of all autumn and winter salads. It is commonly known in restaurants as Chicorée, and is especially refreshing when served as lettuce with plain French dressing. Sow seed from middle of June till last of August. When the plants are fully grown, tie all the outside leaves together over the heart, to blanch the inner leaves, which will take about a week. Do not tie up when the leaves are wet, as they will then decay.

BROAD-LEAVED BATAVIAN (Escarolle). The leaves are broad and thick, more or less twisted and waved, with round ends and are of a bright deep green with a nearly white midrib. They are much larger in size, thicker and more fleshy than those of the preceding sorts. The inner leaves form a fair head which blanches a creamy white. In its natural state Escarolle forms an excellent salad with an appetizing piquancy. It may be gathered fresh from the ground well into winter, thus furnishing salad at a season of the year when it is most welcome. Escarolle is also frequently served as spinach, when its flavor and health-giving properties render it of high value. Pkt. Io cts., oz. $30 \mathrm{cts}$., 1/4lb. $75 \mathrm{cts}$., lb. $\$ 2$.

GREEN CURLED. The hardiest and most vigorous variety. The leaves are bright green, finely cut and wrinkled, giving the plant a handsome appearance. Blanches easily a creamy white. Pkt. Ioc., oz. 30 cts., 1/4lb. 75 cts., lb. $\$ 2$.

\section{KALE}

One ounce will produce about 300 plants

Culture.-Sow in May in shallow drills; when large enough. transplant singly into rows, allowing 24 inches between the plants. The cooking quality of Kale is improved by frost.

DWARF GREEN CURLED SCOTCH. This withstands frost better than cabbage. In fact, it is not at its best until cold weather has set in. The leaves are curled like fine parsley. As boiled "greens," Scotch Kale is tender and of remarkably fine flavor. Pkt. Io cts., oz. 30 cts., 1/4lb. 75 cts., 1b. $\$ 2$.

SIBERIAN KALE OR SPROUTS. Is not so densely curled as the Scotch, but is also hardy and yields a heavy bulk of produce. Widely known as "German greens." Pkt. Io cts., oz. 30 cts., I/4lb. 75 cts., lb. $\$ 2$.

\section{KOHLRABI}

One ounce will sow about 200 feet of drill

CULTURE-This is a very delicious vegetable, and is increasing in popularity rapidly; combines the good qualities of the turnip and cabbage, but excels both in nutritive and productive qualities. Cooked the same as turnips, they are very tender and palatable. Sow in spring in rows 18 inches apart, and thin away the plants to 6 inches.

EARLY WHITE VIENNA. The earliest and best for either market or family use. Pkt. Io cts., oz. $35 \mathrm{cts}$., $1 / 4 \mathrm{lb}$. \$I, lb. $\$ 3$.

EARLY PURPLE VIENNA. Similar to the preceding, except in color, which is of a bluish purple. Pkt. I5 cts., oz. $35 \mathrm{cts.,} 1 / 4 \mathrm{lb}$. $\$$ r, lb. $\$ 3$. 


\section{STUMPP \& WALTER CO., 204-206 N. EUTAW ST., BALTIMORE, MD.}

\section{LETTUCE One ounce will sow}

Because the number of good sorts of Lettuce is so great as to prove bewildering to the majority of home-gardeners, we have selected for them the following, which, in our many years of experience, have never disappointed where the cultural directions were followed.

CULTURE.--About the middle of March sow either Big Boston or May King, in the hotbed. When seedlings are about 2 inches tall, transplant them 4 inches apart each way in a coldframe. By May I, after properly hardening them, set out in the garden, I foot apart in the row, with a 2 -foot path between the rows. These plants should give you firmly folded, well-developed heads by Decoration Day. As soon as the ground can be worked outdoors, plant seeds of any of the early sorts in rows, $1 / 4$ inch deep. As soon as seedlings are 3 to 4 inches tall, thin them to stand 4 inches apart in the row. Later on remove every other one and do this again until the plants finally stand 16 inches apart in the row. Then hoe between the plants as well, in order to secure good heads. After the middle of May, do not sow seeds of early kinds, but select sorts like New York and Iceberg instead. Make repeated sowings of short rows to have a crisp product available constantly.

BIG BOSTON. A splendid head Lettuce, perhaps the most generally and favorably known of the ten mentioned here. Forced in frames to great extent in the spring and is also planted in August for late crop. Does not do well for midsummer use, but as a fall or early spring Lettuce is one of the best. Large heads; center crisp and of fine flavor. Pkt. IO cts., oz. 30 cts., I/4lb. 75 cts., 1b. $\$ 2$.

EARLY CURLED SIMPSON. A splendid curly-leaved sort. Seed sown in the coldframe about the middle of March and transplanted about the middle of April will supply the table from May until the middle of June. Pkt. Io cts., oz. 30 cts., I/4lb. 80 cts., 1b. \$2.25.

MAY KING. Unquestionably one of the best all-round, early, outdoor Lettuces. Does remarkably well in cold or wet weather, forming solid heads of bright green, the edges of the center leaves tinged reddish brown; the heart is clear yellow and of ideal flavor. If sown the same times as Wayahead, May King will be ready about four to five days later. This variety is sown in August for fall use. Pkt. Io cts., oz. 35c. $1 / 4$ lb. $\$ \mathrm{I}, \mathrm{lb} . \$ 3$.

PARIS WHITE COS, or ROMAINE. A splendid sort for summer use; leaves quite erect. Pkt. Io cts., oz. $35 \mathrm{cts}$., I/4lb. $\$$ I, $1 \mathrm{~b}$. $\$ 3$.

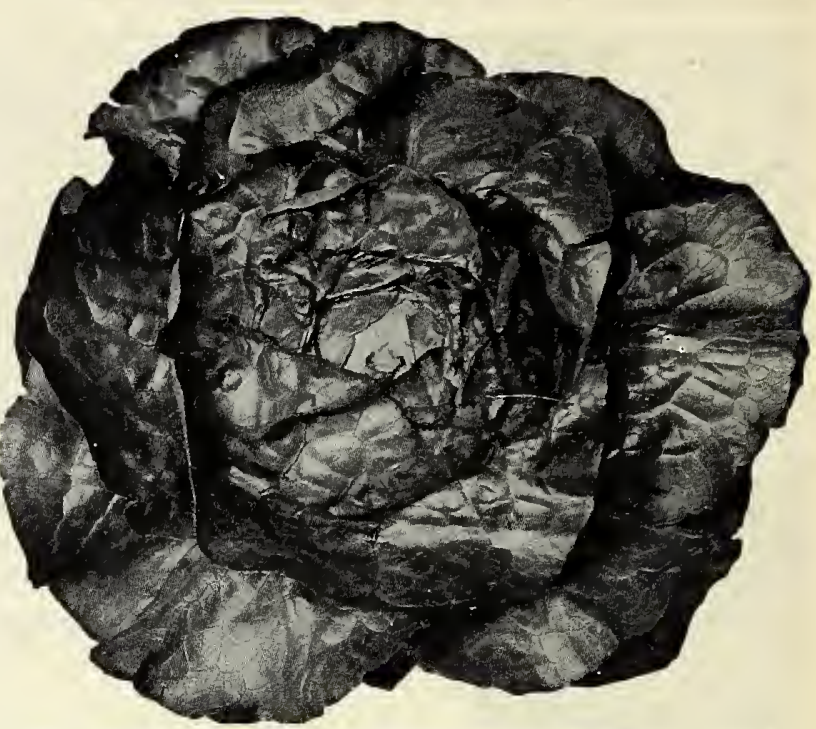

Big Boston. Everybody's Favorite for outdoor use and forcing

ICEBERG. (California Simpson.) A splendid, crisp-head sort. Few Lettuces resist the heat better. Has strong center ribs which bend toward the heart of the plant, keeping it thoroughly blanched. Repeated sowing from early May, of this sort and New York or Wonderful, at intervals of three weeks, should supply the table well up to September I. Pkt. Io cts., oz. $30 \mathrm{cts.}$ I/4lb. 75 cts., Ib. $\$ 2$.

NEW YORK, or WONDERFUL. This variety grows considerably larger than Iceberg and matures about ten days later. The outer foliage is a distinct, dark green as compared with the yellowish green of Iceberg. Pkt. I5 cts., oz. $50 \mathrm{cts}$., $1 / 4 \mathrm{lb}$. \$I.40, Ib. \$4.

\section{LEEK One ounce will sow about}

CuLTURE.- Sow the seed very early in a seedbed in a sheltered place, if possible When plants are about 6 inches long transplant them to trenches 6 inches deep, with very rich soil at the bottom. Fill up the trenches as the plants grow, and later draw soil up to them. As a result you will have fine, large Leeks blanched half a foot long, which may be kept all winter if dug up with the roots on and stored in moist sant

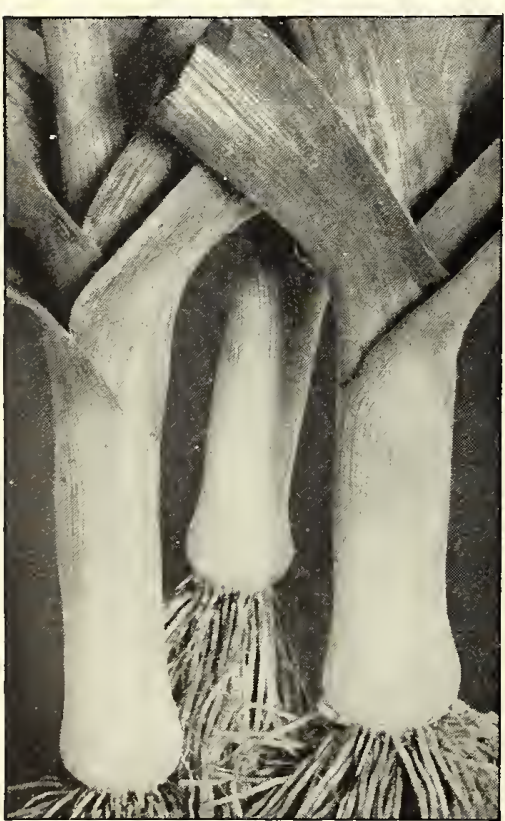

American Flag Leek. The standard variety for general use

\section{in the cellar.}

LARGE AMERICAN FLAG. A large-growing type, desirable in every way. On account of its dependability and ease of culture, is the most widely used variety for both family and market use. Pkt. I5 cts., oz. 35 cts., I/41b. $\$$ I, 1 b. $\$ 3$.

\section{MUSTARD $\begin{gathered}\text { One ounce will sow } \\ 75 \text { feet of drill }\end{gathered}$}

CulruRE.-Sow frequently through the spring, in drills from 8 to I2 inches apart.

GIANT SOUTHERN CURLED. The plant grows 3 feet tall, and the broad succulent leaves are cut and frilled. The variety makes excellent boiled "greens." Pkt. Io cts., oz. 20 cts., I/4lb. 55 cts., lb. \$I.50.

WHITE LONDON. The best variety for sandwich material and for salads, when it is used in the seedling stage but a few days after sowing. Pkt. Io cts., oz. $20 \mathrm{cts}$., I/4lb. $55 \mathrm{cts}$., 1b. \$I.50.

\section{MUSHROOM SPAWN}

Ten bricks will spawn 10 feet square

AMERICAN PURE CULTURE SPAWN. This type produces larger Mushrooms than the English, coming into bearing somewhat earlier, and continuing to crop for a long time. This spawn is produced by selecting spores from individual specimen Mushrooms, and is propagated and transferred to the bricks of manure, which, when planted, produce Mushrooms all of one type. Ten pounds will spawn Io feet square. Per Brick (about $13 / 2$ lbs.) 35 cts., Io Bricks $\$ 3.25$, 25 Bricks $\$ 7$, 100 Bricks $\$ 25$.

\section{BOTTLE SPAWN. A New Process}

\section{One quart will spawn 35 square feet}

In this new method the spores are propagated in sterile glass bottles, the Spawn removed, dried, and packed in cartons. Excluded from the Spawn are the spores of other fungous growths, many of which are highly poisonous; no insect eggs, flies, or weed seeds. Pieces the size of a nut are planted in the usual way. In white, light brown, and cream colors. Qt. \$1.25, 6 qts. $\$ 6.50$, I2 qts. \$I 2 . 


\section{MUSKMELON}

One ounce will sow about 80 hills

Culture.- - Sow the seed in April under hand glasses, and in the open air in May in hills 6 feet apart each way. Plant in each hill from 8 to Io seeds, covering half an inch deep. When the plants have produced their rough leaves, thin out to three plants. The hills should be prepared by trenching in rotten manure and sand. As soon as the plants make their appearance above ground, dust them with soot, charcoal dust or Bug Death, to prevent the ravages of the bug.

\section{Green-Fleshed Kinds}

S. \& W. CO.'S SELECTED STOCK, ROCKY FORD. This famous variety is the finest early green-fleshed melon in cultivation. The fruits are remarkably uniform in size, weighing from $I \frac{1}{4}$ to $I^{I} / 2$ pounds each. They are quite thick meated, with very thin rinds; skin light green, regularly ribbed and heavily netted, turning to a golden yellow as the melon ripens. Flesh light green in color, firm but melting and of uniformly fine flavor. Pkt. Io cts., oz. $30 \mathrm{cts}$., 1/4Ib. 75 cts., Ib. \$2.

HONEY DEW. This variety, with its clear light yellow skin, is becoming quite familiar in the best markets. No other melon is quite so sweet as this, and it is not surprising that it should become so popular. The flesh is green, very thick, and unlike some Melons it ripens uniformly to the rind. Pkt. I5 cts., oz. $35 \mathrm{cts} ., 1 / 4 \mathrm{lb}$. $\$ \mathrm{I}$, lb. $\$ 3$.

\section{Orange-Fleshed Kinds}

SELECTED EMERALD GEM. The skin is a rich deep green, and smooth; flesh salmon color and of delicious flavor. A very early and prolific variety and one that is very extensively grown for family use. Pkt. Io cts., oz. $30 \mathrm{cts}$, 1/41b. $75 \mathrm{cts}$., Ib. $\$ 2$.

SUPREME. Well grown fruits weigh as much as $\mathrm{I}_{5}$ pounds each. The delicate salmon-tinted flesh is of exquisite flavor. Pkt. 25 cts., 5 for $\$ \mathrm{I}$.

\section{WATERMELON}

One ounce will plant about 50 hills

CulruRE.-Tr eat the same as muskmelon, except that they should be planted 8 to ro feet apart, according to variety.

COLE'S EARLY. A most delicious and productive variety for the family garden, succeeding in northern states, where melons were never matured before. The flesh is of a beautiful bright red color, crisp and extremely delicate in texture-that granulated, cool, sparkling appearance that is so captivating to the eye; in flavor it is lusciously sweet and refreshing, no pithiness or stringiness. Pkt. Io cts., oz. 30 cts.,

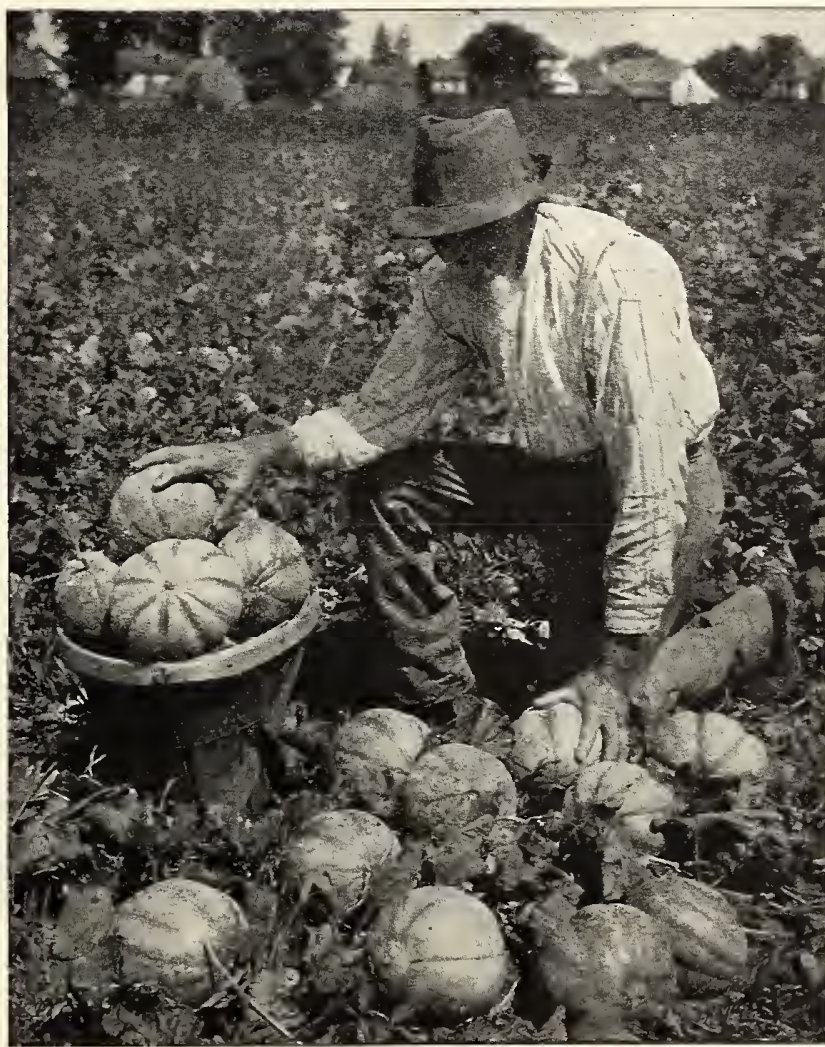

S. \& W. Co.'s Selected Stock, Rocky Ford. The most popular green-fleshed Muskmelon

KLECKLEY SWEETS. The sweetest of all the Watermelons. Fine-flavored and grained, tender meat. Fruits are large size; rind very thin and green, very brittle; flesh scarlet and firm; and a variety everyone should grow. Pkt. Io cts., oz. 30 cts., 1/4 Ib. $75 \mathrm{c}$., lb. $\$ 2$.

TOM WATSON. A large, long melon, with a tough rind. The vines are vigorous and productive, while the flesh is rich red, sweet, and tender. A variety to be recommended. Pkt. Io cts., oz. $20 \mathrm{cts}$., I/4lb. 55 cts., lb. \$I.5O.

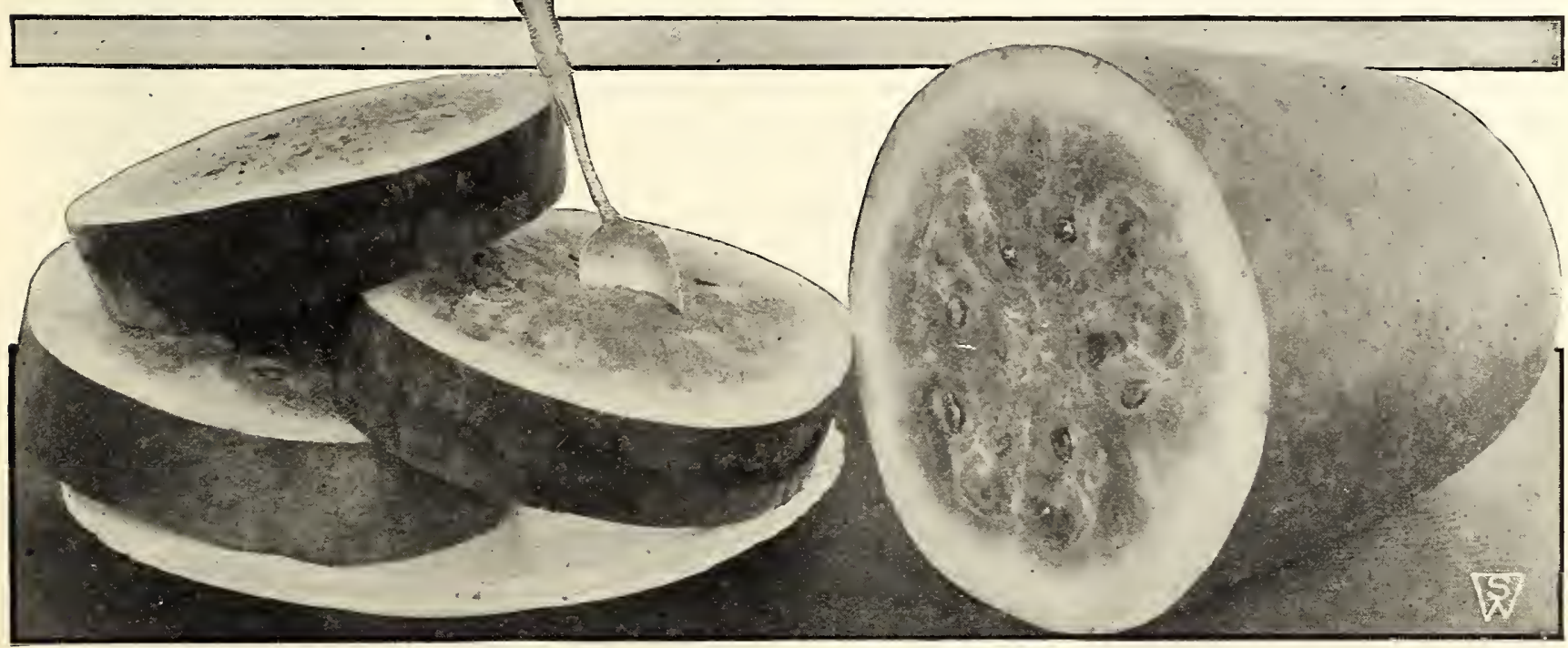

Kleckley Sweets. The sweetest of all Watermelons 


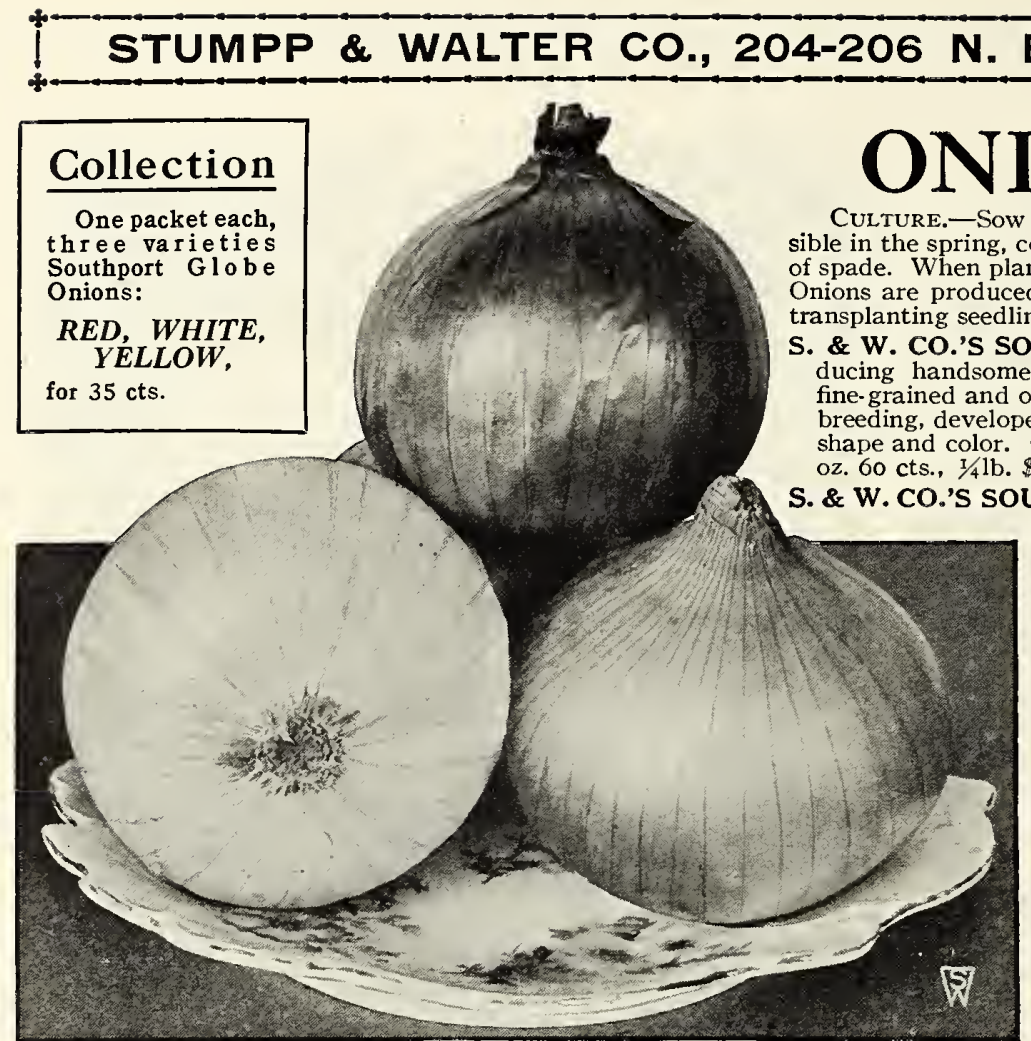

S. \& W. Co.'s Southport Globe Onions

Culture.-Sow in rich, sandy soil, in drills I foot apart, as early as possible in the spring, cover with fine soil and firm well, either with roller or back of spade. When plants are strong enough, thin out to 3 or 4 inches. The finest Onions are produced by sowing the seed in a hotbed early in February and 政

$\&$ W. CO.'S SOUTHPORT WHITE GLOBE. Yields abundantly, pro-
ducing handsome and uniformly globe-shaped bulbs. The flesh is firm, fine-grained and of mild flavor. We have, by years of careful selection and

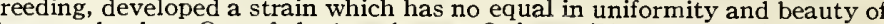
shape and color. One of the best known Onions. Pkt. I 5 cts., $1 / 2 \mathrm{oz} .35 \mathrm{cts}$., oz. 60 cts., 1/4lb. $\$$ I. 60 , lb. $\$ 4.50$. in color, having a deep red skin, but differing in shape, Deing almost a perfect globe. Size large, flesh finegrained, mild and tender. Pkt. I 5 cts., $1 / 2 \mathrm{Oz} .30 \mathrm{cts}$., oz. 55 cts., $I / 4$ lb. $\$ 1.50,1 \mathrm{~b}$. $\$ 4$.

S. \& W. CO.'S SOUTHPORT YELLOW GLOBE. We can ccnfidently claim superiority for our strain of seed; it produces large and uniformly spherical bulbs with very small necks. The largest diameter is below the center of the bulb. The color is a rich orange-yellow. Keeps splendidly. Pkt. Io cts., $1 / 2 \mathrm{Oz}$. 25 cts., oz. 45 cts., 1/4lb. \$1.30, lb. \$3.50.

YELLOW GLOBE DANVERS. Of more globular shape than the Southport; a splendid keeper, producing well-rounded bulbs about $2 \frac{1}{2}$ inches in diameter. Pkt. Io cts., $1 / 20 z$. 25 cts., oz. 45 cts.. $1 / 4 \mathrm{lb}$. $\$ 1.30,1 \mathrm{~b} . \$ 3.50$.

WHITE PICKLING. When matured, the tops die down, leaving beautiful and perfect little bulbs. The color is pure white, flavor mild and delicate, perfectly adapted for pickling and table use. Pkt. I 5 c., I/2Oz. 3Oc., Oz. 50c., I/4lb. $\$$ I.35, lb. $\$ 3.75$.

PRIZETAKER. Grows uniform in shape; is of immense size, measuring from I 2 to $\mathrm{I} 6$ inches in circumference, while under special cultivation specimen bulbs have been raised to weigh from 2 to 3 pounds each; its pure white flesh is fine.grained, mild, and delicate in flavor. Pkt. I5 cts., $1 / 20 z .30 \mathrm{cts}$., oz. $55 \mathrm{cts}$., $1 / 4 \mathrm{lb}$. $\$ \mathrm{I} .5 \mathrm{O}, \mathrm{lb}$. $\$ 4$.

\section{ONION SETS The Reason for Planting Onion Sets}

Our Globe Onion Sets will produce Onions much earlier than by sowing the seeds, which frequently permit the planter to sow another crop on the land the same year. For green or bunch Onions, sets will produce a crop in half the time it takes to raise them from seed. Plant Onion Sets and Tops near the surface in drills 12 inches apart and 4 inches in the rows.

White Onion Sets.

Yellow Onion Sets.

Red Onion Sets.

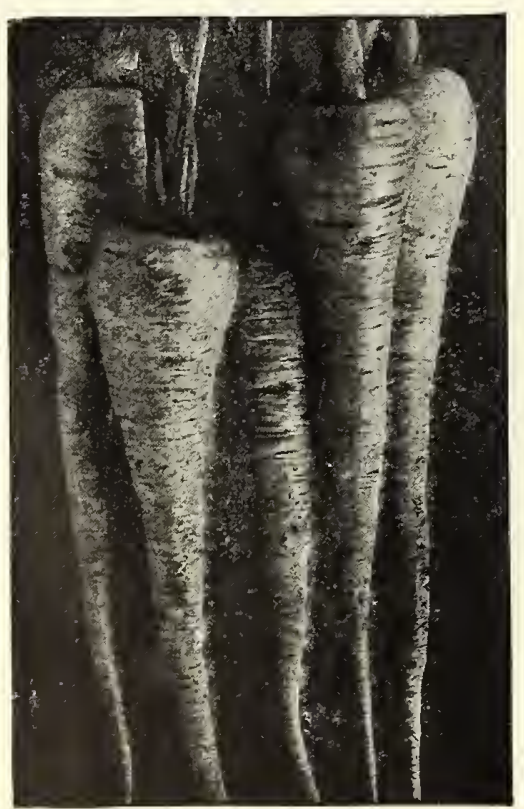

Hollow-Crown Parsnips \$ot. 45 \$1 I 60 pk $\$$ \$3

$\begin{array}{llllll}40 & \text { I } & 50 & 2 & 75\end{array}$

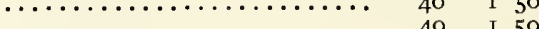

\section{OKRA, or GUMBO}

One ounce will sow about 100 feet of drill

Culture.-Sow when the weather is warm and settled, in drills I inch deep and 4 feet apart; thin out to $I 2$ inches apart in the drills. Okra requires 9 to Io weeks from seed to maturity. Usual sowing period for New York, May 25 to June Io. LONG GREEN. Long ribbed pods; very productive. Pkt. Io cts., oz. I5 cts., I/4lb. 40 cts., lb. \$I.

WHITE VELVET. Very distinct in appearance; pods are perfectly round, smooth and of a white velvety appearance and of superior flavor. Pkt. Ioc., oz. $20 c$., $1 / 4 \mathrm{lb} .55 \mathrm{c}$., Ib. $\$ \mathrm{I} .5 \mathrm{O}$.

\section{PARSNIP}

One ounce will sow about 200 feet of drill; 5 to $6 \mathrm{lbs}$. for an acre

CULTURE-Sow as early in spring as the ground can be worked, in drills I 8 inches apart, covering with fine soil to the depth of $1 / 2$ inch. The soil should be rich and deeply dug. The quality of the roots is much improved after a severe frost; in fact, they may be allowed to remain in the ground throughout the winter, as they are perfectly hardy.

S. \& W. CO'S IMPROVED HOLLOW-CROWN. A great improvement over the present Hollow-Crown variety; clean, well shaped and smooth. Smoothness in the root of a Parsnip is a matter of importance, as every housewife preparing it for the table will acknowledge. Excellent for table or exhibition. Pkt. Io cts., 0z. 25 cts., 1/4lb. 65 cts., lb. $\$$ I.75.

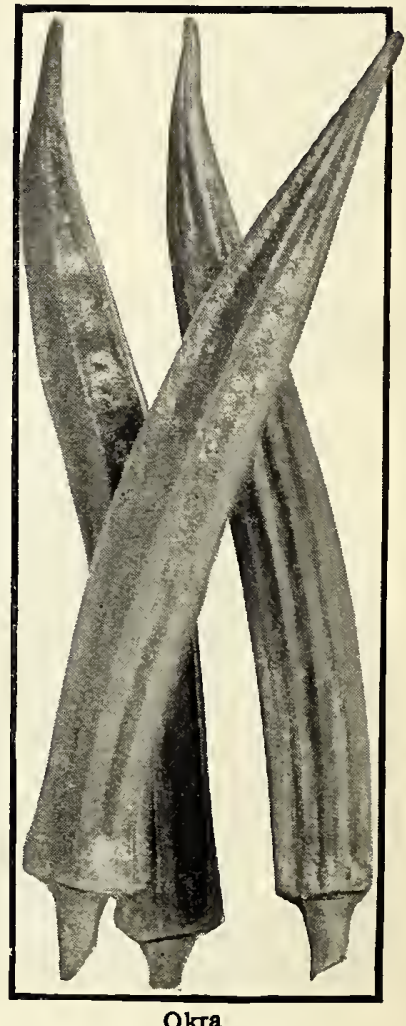

Okra 


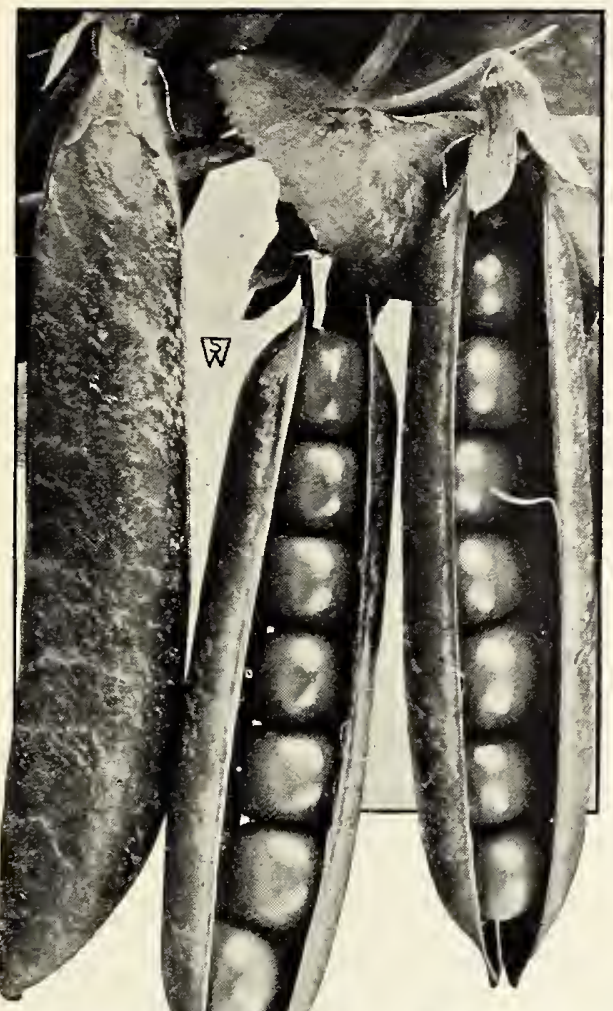

\section{One pound will plant D $\mathrm{D} \mathrm{S}$ NORTHERN- 100 feet of drill}

If wanted by mail, add 5c. per $1 / 2 \mathrm{lb}$, $10 \mathrm{cts}$. per $1 \mathrm{~b} ., 15 \mathrm{cts}$ per $2 \mathrm{lbs}$., to the prices listed CULTURE.-For early crops sow as early in spring as practicable, and again every two or three weeks for a succession throughout the season up to the Ist of August. Plant in single or double rows, 4 feet apart and 2 inches deep. In dry weather soak the Peas over night before planting. In the vicinity of New York the extra-early Peas, if planted from the I 5 th to the last of August, will produce a medium crop for late picking when they will be found most acceptable.

Varieties marked * are wrinkled Marrows, and should be sown more thickly than the round Peas, and not until the ground has become warm, as they are more liable to rot. All wrinkled sorts are much superior in flavor to the round Peas.

\section{EARLY SMOOTH-SEEDED SORTS}

FIRST OF ALL or PEDIGREE EXTRA-EARLY. Extremely hardy and early. The first planting of Peas should be with First of All. It is a smooth-seeded variety. a splendid cropper; Peas very tender, of good flavor and carried in long, tightly filled pods. Height $21 / 2$ feet. $1 / 2$ lb. 25 cts., lb. 40 cts., 2 lbs. 75 cts., 5 lbs. $\$$ I. 75 , I 5 lbs. $\$ 4.75$.

EARLY BIRD. A Pea which combines the hardiness of the round-seeded types with the quality of the later wrinkled Marrowfats. The plant grows 4 to $4 \frac{1}{2}$ feet high, and therefore requires the support of brush, wire, or strings. $1 / 2 \mathrm{lb} .25 \mathrm{cts}$., lb. $45 \mathrm{cts}$., 2 lbs. 85 cts., 5 lbs. $\$ 2$, I 5 lbs. $\$ 5.50$.

MARKET SURPRISE. On vines 3 feet tall, Market Surprise bears $3^{1 / 2}$-inch pods in great quantities, within 60 days from date of sowing. It is thus but four days later than the best extra early, while the pods contain on an average two more Peas, and the Peas are larger. They are of truly remarkable sweetness. Pkt. $15 \mathrm{cts}$., $1 / 2 \mathrm{lb} .30 \mathrm{cts}$., lb. 55 cts., 2 lbs. $\$$ I, 5 lbs. $\$ 2.25,15$ lbs. $\$ 6.25$.

\section{EARLIEST WRINKLED SORTS}

*GRADUS, or PROSPERITY. Undoubtedly one of the most valuable sorts introduced up to the present time. The vine has heavy stems, with large, light green leaves and grows about 3 feet high. It produces uniformly large pods, measuring from 4 to $4 \frac{1}{2}$ inches in length, nearly round and well filled with very large, handsome Peas of the finest flavor; very early. 3 feet. Pkt. Io cts., 1/2lb. 25 cts., lb. 45 cts., 2 lbs. 85 cts., 5 lbs. $\$ 2$, I 5 lbs. $\$ 5.50$.

*LAXTONIAN. A very fine dwarf early Pea. Unusually large pods, borne on long-

Laxtonian Peas growing, sturdy vines. Unlike many of its class, the large pods are filled with large, luscious Peas. It is ready for use about a week later than the very early sorts. The plants grow about $1 \mathrm{~s} / 2$ feet high, and are of a rich dark green color, which proves it to be of vigorous constitution, and this enables it to resist the extreme conditions to which Peas are subjected in many sections of the United States. (See photograph.) 1/21b. $30 \mathrm{cts}$., lb. 50 cts., 2 lbs. 90 cts., 5 lbs. $\$ 2.10$, I 5 lbs. $\$ 5.75$.

*THOMAS LAXTON. A remarkably fine, early, wrinkled Pea, and we think destined to supersede Gradus. In many characteristics it resembles that excellent sort, but the pods differ in shape, and are certainly more numerous. The Peas are of extra-fine quality, tender, and of a flavor not excelled by any other. It grows about 3 feet in height, but does not need brushing. Height 3 feet. $1 / 2 \mathrm{lb}$. $25 \mathrm{cts}$., $1 \mathrm{~b}$. $45 \mathrm{cts}$., 2 lbs. 85 cts., 5 lbs. $\$ 2, I_{5}$ lbs. $\$ 5.50$.

*SUTTON'S EXCELSIOR. A variety that calls for highest commendation; equal to Gradus in quality and more productive. Ready for picking just after Gradus and Little Marvel. Height I8 inches. I/21b. 25 cts., 1b. 45 cts., 2 lbs. 85 cts., 51 bs. $\$ 2$, I5 lbs. $\$ 5.50$.

\section{MIDSEASON AND MAIN-CROP SORTS}

*ALDERMAN. A distinctly different Pea in habit from those described in the Early list. On generous soils it grows to a height of 5 to 6 feet. and should be supported with brush or trellises. The pods contain seven large, elongated, dark green Peas of the highest quality. Height 5 feet. $1 / 2$ lb. 25 cts., lb. 45 cts., 2 lbs. 85 cts., 5 lbs. $\$ 2$, I5 lbs. $\$ 5.50$.

*BOSTON UNRIVALED, or TELEPHONE. This variety is much like Alderman, with vines fully as tall, pods slightly smaller, and bears right up to the season of the very late sorts. The Peas are every bit as tender, but darker green in color and sweet. Height 5 feet. Pkt. IOc., 1/2lb. 25 c., lb. $45 \mathrm{c}$, 2 lbs. 85 c., 5 lbs. $\$ 2$, I 5 lbs. $\$ 5.50$.

CHAMPION OF ENGLAND. Vines grow 4 to 5 feet high. Peas of excellent quality and delicious flavor. $1 / 2 \mathrm{lb} .25 \mathrm{cts} ., \mathrm{lb} .45 \mathrm{cts}$. 2 lbs. 85 cts., 5 lbs. $\$ 2$, I 5 lbs. $\$ 5.50$.

*POTLACH. Really an improved Stratagem and, without a doubt, the best dwarf, extremely late Pea. Height 2 feet. Pkt. Io cts., I $/ 2$ lb. 25 cts., lb. 45 cts., 2 lbs. 85 cts., 5 lbs. $\$ 2$, I5 lbs. $\$ 5.50$.

\section{PARSLEY One ounce will sow about}

Culture.-Parsley requires a rich, mellow and deep soil. Sow early in the spring in drills I foot apart and $1 / 2$ inch deep. Thin out the young plants to 4 inches.

S. \& W. CO.'S EXHIBITION CURLED. This Parsley is remarkable for its fine leaves and close habit. In flavor it is superior to that of any known variety, and it is very tender. The seed offered has been saved from exhibition plants only. Pkt. $25 \mathrm{cts}$., 5 pkts. $\$ \mathrm{I}$.

CHAMPION MOSS CURLED. A bed of this has the appearance of fine moss. Pkt. Io cts., oz. 20 cts., $1 / 4$ lb. 55 cts., lb. $\$$ I. 50.

PLAIN. Known widely as Italian Parsley. Used for flavoring. (See illustration.) Pkt. Io cts., oz, $20 \mathrm{cts.,}$ 1/4lb. $55 \mathrm{cts}$., lb. \$I.50.

HAMBURG or ROOTED. The roots of this type resemble parsnips. They are served similarly or used for flavoring soups. Pkt. Io cts., oz. 25 cts., $1 / 4$ lb. 65 cts., lb. $\$$ I. 75 .

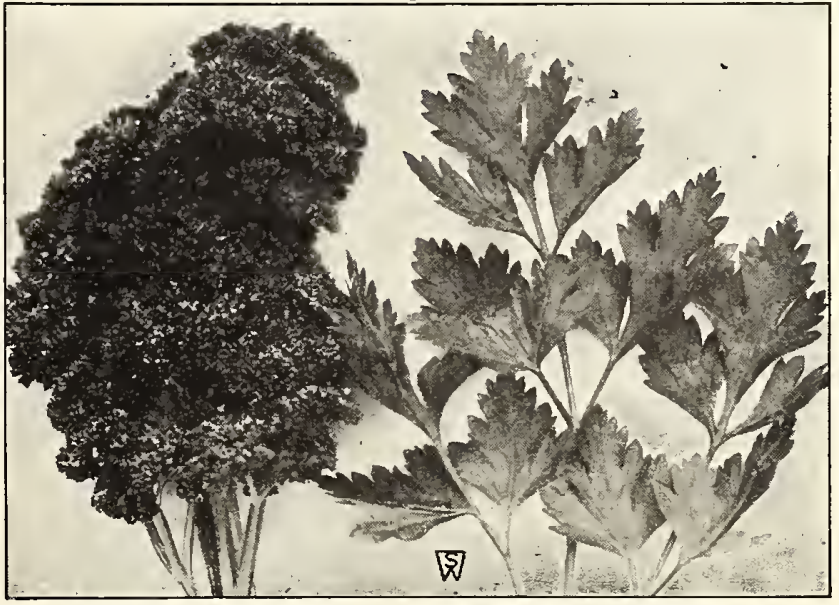

Champion Moss Curled and Plain Parsley compared 


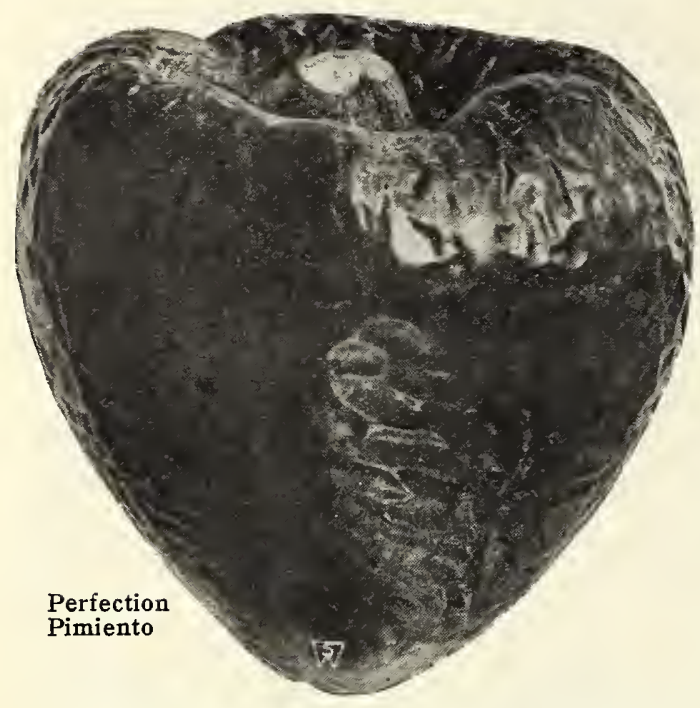

\section{PEPPERS}

One ounce will produce about 1,000 plants

CULTURE.-Peppers are more sensitive to frost than most vegetables, and they should not be planted out until settled warm weather has arrived. The seed should be sown in a hotbed, coldframe, or if no better convenience is available, a box in a window; transplant later into rows 20 inches apart each way, and keep the soil clean and well stirred.

PERFECTION PIMIENTO. One of the best for the home-garden, both green and ripe. It is so smooth and uniform in shape that the skins can be easily slipped off after heating over a hot fire a few seconds or by boiling a few minutes in hot water. It can also be pared like an apple by using a sharp knife. The green Peppers can be pared best in this way. The hull or meat is from 2 to 3 times as thick as that of the Bell types, and yields about a half more edible product to the same measurement. The quality is very sweet and delicious and entirely free from pungency. In color, when ripe, it is a beautiful scarlet-red. It is very productive, yielding heavy crops until cut off by frost. This Pepper will be much sought and grown by canners for pimientos, pickles and pulp. Pkt. I5 cts., $1 / 2 \mathrm{Oz}$. $50 \mathrm{cts}$., $0 z .85 \mathrm{cts}$., $1 / 4 \mathrm{lb}$. $\$ 2.5 \mathrm{O}$.

RUBY KING. The handsome fruits are $4 \frac{\mathrm{I}}{2}$ to 6 inches long, 4 inches thick, and bright red. Ruby King is used very largely for pickles, and it is equally suited for slicing. The flavor of the fruits is mild and pleasant, with just a slight suspicion of piquancy, making them very tempting when served like cucumbers or tomatoes. Pkt. Io cts., $\mathrm{I} / 2 \mathrm{Oz}$. $45 \mathrm{cts}$., oz. $75 \mathrm{cts}$., $\mathrm{I} / 4 \mathrm{lb}$. $\$ 2.25$.

LARGE BELL, or BULL NOSE. A large, early variety of pleasant flavor, though mild. This is the variety for green stuffed Peppers. Ripens into a bright red. Pkt. Io cts., $1 / 2$ oz. $45 \mathrm{cts}$., oz. $75 \mathrm{cts}$., $1 / 4 \mathrm{lb}$. $\$ 2.25$.

LONG RED CAYENNE. Fruits about 4 inches long and $\mathrm{I}$ inch thick, bright red in color; very prolific; very hot. Used for pickling, both when green and when ripe. Pkt. I5c., $1 / 20 z$. 6oc., oz. $\$ I, 1 / 4 \mathrm{lb} . \$ 2.75$.

\section{POTATOES FOR SEED}

CUlTURE.-Any good, well-drained, fibrous loam will produce Potatoes under right climatic conditions. For early Potatoes, which mature in eight to ten weeks from planting, the soil must be particularly rich. A rich clover sod, manured and broken the year before and planted to corn, beans, peas, oats, etc., is in best shape for giving a good yield of nice, clean Potatoes. Stable manure had better be applied to the land the year before. S. \& W. Co.'s Potato Manure, at the rate of up to I, ooo pounds to the acre if applied broadcast, or 400 to 600 pounds if applied mostly in the rows, may be used directly for the Potato crop. Open furrows 3 feet apart and 3 to 4 inches deep. Apply the fertilizer and run the furrower or small plow again in the furrow to mix the fertilizer with the soil and leave a mellow seed-bed. Then plant good-sized pieces, each containing not less than two or three eyes, I5 inches apart in the furrows for early Potatoes, and I8 inches apart for late ones. Return the soil with a coverer, small plow or other suitable tool.

IRISH COBBLER. A variety that is more largely used as an early variety than any other. The flesh is white and of fine quality. $1 / 2 \mathrm{pk} .75 \mathrm{cts}$., pk. $\$$ I.20, $1 / 2$ bus. $\$ 2$, bus. $\$ 3.50$, bbl. $\$ 7.50$.

EARLY ROSE. (Selected.) A variety which has been grown extensively in some sections. A Potato of good size and fine quality. $2 / 2 \mathrm{pk} .75 \mathrm{cts}$., pk. $\$$ I.25, I/2 bus. $\$ 2.25$, bus. $\$ 3.75$, bbl. $\$ 8$.

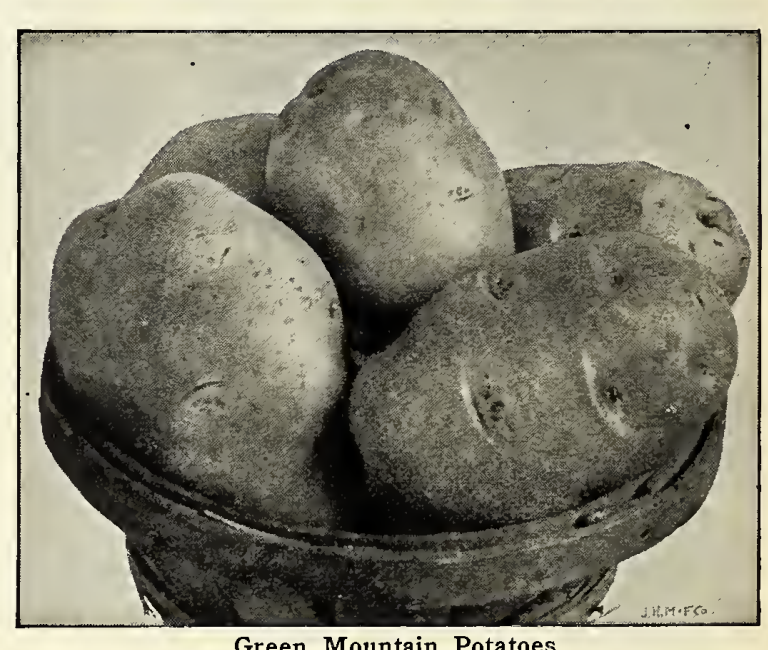

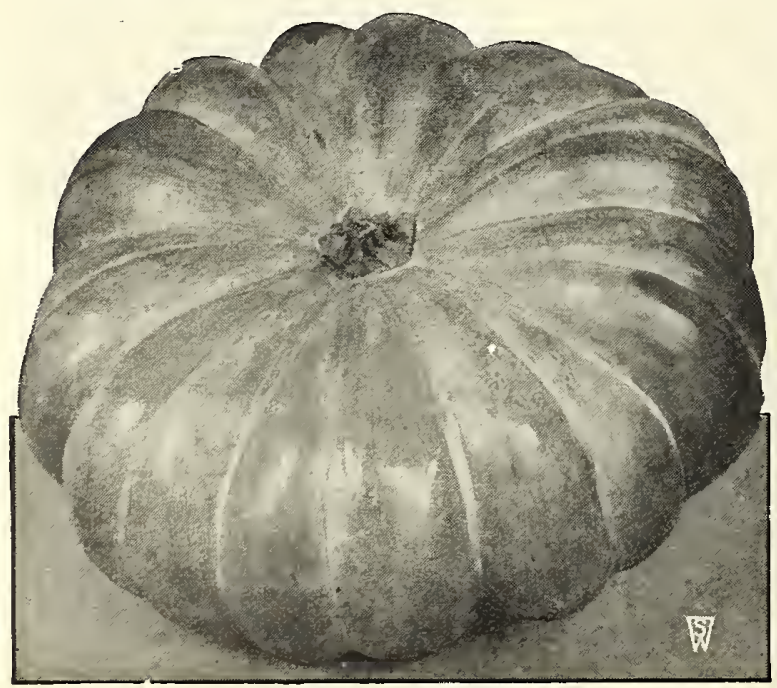

Large Cheese Pumpkin
GREEN MOUNTAIN. (Selected Stock.) A late, heavy cropper of excellent quality; skin smooth and white; shape roundish flat; eyes few and shallow; a good keeper. $1 / 2$ pk. 75 cts., pk. $\$ 1.20,1 / 2$ bus. $\$ 2$, bus. $\$ 3.50$, bbl. $\$ 7.50$.

\section{PUMPKINS \\ One ounce will plant 50 hills}

Culture.-Plant in April or May, among corn, or in the garden, in hills 8 to ro feet apart, and otherwise treat in the same manner as melons.

LARGE CHEESE. A most popular variety. Fruit flattened, the diameter being two or three times more than the length; skin mottled light green and yellow, changing to rich cream-color as it matures; flesh tender and of excellent quality. Pkt. Io cts., oz. 25 cts., I/4lb. 65 cts., lb. \$I.75.

SWEET, or SUGAR (New England Pie). The fruits are medium to small in size, of a bright orange color, and in shape are round, flattened at the ends. The flesh is of remarkably good cooking quality, very thick, and deep yellow in color. Pkt. Io cts., oz. 25 cts., 1/4lb. 65 cts., lb. $\$$ I. 75 .

KING OF THE MAMMOTHS. Recommended where size is the chief consideration-200 pounds or more being not an unusual weight for a single specimen. The fruit is flat-round; the skin is yellow, as also is the thick flesh. Pkt. Io cts., oz. 35 cts., I/4lb. $\$$ I, 1b. $\$ 2.75$.

WINTER LUXURY. This we recommend as one of the best pie Pumpkins; an excellent keeper and enormously productive. It is very finely netted and in color it is a golden russet. Pkt. Io cts., 02. 35 cts., 1/41b. 90 cts., lb. $\$ 2.50$. 


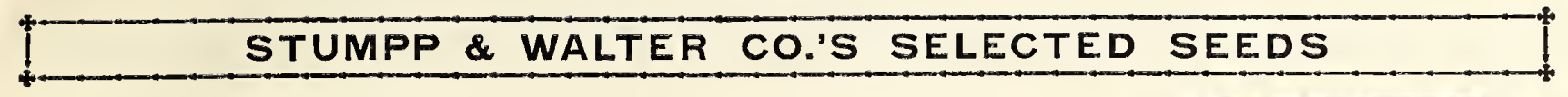

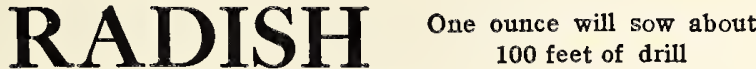

As early in the spring as the soil can be worked, sow any of the early round or olive-shaped varieties in rows, $1 / 2$ inch deep, with a foot to 18 inches between the rows. Sow thinly. If seedlings appear closer than I inch apart, they should be "thinned out." Hoe frequently to encourage rapid growth which insures high quality. The early spring sorts serve the purpose until June I5, when Icicle and Cincinnati Market are at their best. The summer sorts are good until frost from repeated planting. The winter varieties should be pulled after light frosts and stored like beets. Both summer and winter Radishes should be "thinned" to stand from 4 to 6 inches apart in the row. After the middle of May, do not sow the flat, round, and olive-shaped spring sorts. Sow White Icicle, Cincinnati Market, and Chartier. These resist hot weather well. About July I, sow the winter varieties.

EARLY SCARLET TURNIP. Within 25 days from date of sowing it perfects handsome, flat roots, $3 / 4$ inch in diameter by $1 / 2$ inch deep through. Pkt. Io cts., oz. 20 cts., $1 / 41 \mathrm{~b} .45 \mathrm{cts} ., 1 \mathrm{~b}$. $\$ 1.25$.

SPARKLER. Of rich carmine-scarlet color, with a very pronounced tip of the purest white. The roots, even when fully developed, are solid, crisp and sweet, and remain fit for use as

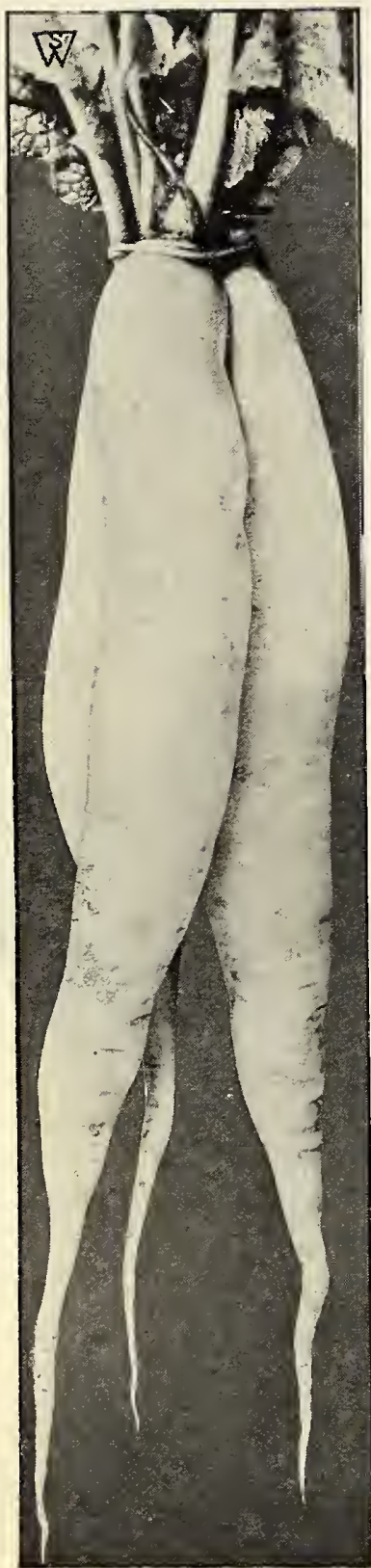

White Icicle Radishes long as the coarser kinds. It is equally well adapted for forcing in frames or growing in the open ground. While the leaves are small, they are sufficiently large for bunching. Pkt. Io cts., oz. 25 cts., $1 / 4 \mathrm{lb} .65 \mathrm{cts}$., $1 \mathrm{~b}$. $\$ \mathrm{I} .75$.

EARLY SCARLET GLOBE. The best general-purpose variety in this class, perfecting handsome roots, as illustrated alongside. in from 28 to 35 days after sowing. Of distinct shape, brilliant color, short-leaved, crisp and white; an excellent variety for forcing. Pkt. Io cts., Oz. 25 cts., $1 / 4$ lb. 65 cts., Ib. $\$$ I. 75 .

FRENCH BREAKFAST. The olive-shaped counterpart of Cooper's Sparkler among the early round sorts, as described above. A favorite sort; mild and crisp. Pkt. Io cts., oz. 20 cts., I $/ 4$ lb. 45 cts., lb. $\$ 1.25$.

WHITE ICICLE. The "best all-round" Radish for all purposes in the home-garden; also fine for market and splendid for growing under glass. Within 30 days from sowing seeds, the roots attain a length of 4 to 5 inches, by $3 / 4$ inch in diameter at the thickest part. The skin is thin, the flesh crisp and mild. It remains in fine table condition longer than any other early sort, regardless of shape. (See illustration.) Pkt. Io cts., oz. 20 cts., $1 / 4$ lb. 55 cts., lb. $\$$ I.5O.

LONG SCARLET CHARTIER, or SHEPHERD. This might be considered "the connecting link" between the foregoing sorts and the very much later kinds that follow. Long Scarlet Chartier is ready in about 45 days after sowing. The 列 pink about the middle, and from thence downward is a pure white. Pkt. Io cts., oz. 20 cts., 1/4lb. 55 cts., lb. $\$$ I. 50 .

CALIFORNIA MAMMO'TH WHITE WINTER. A white-fleshed Radish of excellent quaiity. Pkt. Io cts., oz. $35 \mathrm{cts}$., $1 / 4 \mathrm{lb}$. $90 \mathrm{cts}$., $1 \mathrm{~b}$. $\$ 2.50$.

LONG BLACK SPANISH. The popular winter sort. Pkt. IOc. oz. 25 cts., $1 / 4$ lb. 65 cts., lb. $\$ 1.75$.

\section{RHUBARB SEED}

\section{One ounce will produce about 1,000 plants}

Culture.-Sow early in spring, in drills I inch deep and a foot apart; thin out; transplant the following season 4 feet apart each way.

VICTORIA. Very large, of the finest quality. Pkt. Io cts., oz. 35 cts., $1 / 4$ lb. $\$ I, 1 b . \$ 3$.

\section{RHUBARB ROOTS}

The roots we offer are of the Giant Crimson Winter variety. They may be planted in any good garden soil in the early spring. Divided roots, I 5 cts. each, \$I.5O per doz.; extra.strong clumps, $25 \mathrm{cts}$. each, $\$ 2.50$ per doz.

\section{SCORZONERA}

\section{Black Salsify}

One ounce will sow about 50 feet of drill

Curture-Cultivate the same as salsify. The roots should not be scraped, but simply washed, boiled tender, then peeled and served like asparagus.

IMPROVED. Pkt. I 5 cts., oz. 65 cts., I $/ 4$ lb. $\$$ I. 75,1 b. $\$ 5$.

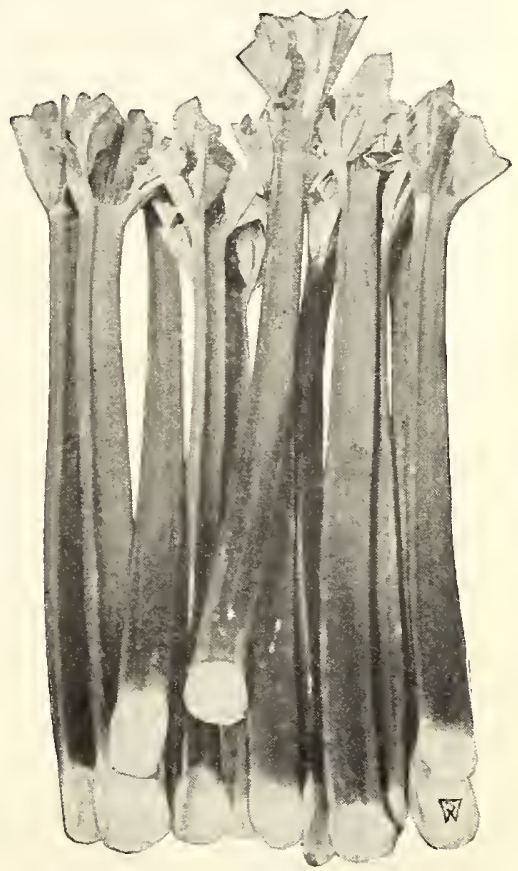

Victoria Rhubarb 


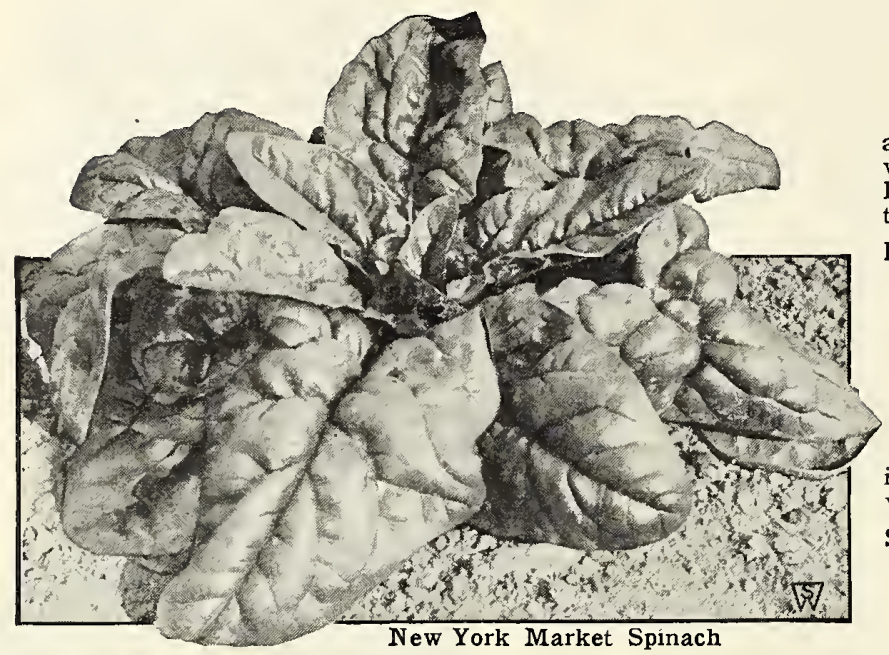

\section{SALSIFY (Vegetable Oyster)}

One ounce will sow about 50 feet of drill

CULTURE.-Sow the seed early in spring, in drills 2 inches apart and $I$ inch deep, thinning out the young plants to 6 inches. The roots will be ready in October, when a supply should be taken up and stored like carrots. Those remaining will suffer no injury by being left in the ground until spring.

MAMMOTH SANDWICH ISLAND. Tender and delicious. Superior to all other sorts. Pkt. Io cts., oz. 35 cts., I/4lb. $\$ \mathrm{I}, 1 \mathrm{~b} . \$ 3$.

\section{SPINACH}

\section{One ounce will sow about 100 feet of drill}

CULture.-Sow in March or April in drills an inch deep and I4 inches apart; again in August or September. Spinach delights in very rich soil-in fact, it is of no use sowing in a poor one.

S. \& W. CO.'S NEW YORK MARKET. (Long Island grown.) This Spinach grows rapidly and produces unusually large, thick, crumpled leaves of beautiful green. Properly cultivated and manured, the plants very often measure 2 feet across, and stand the winter better than any other sort of Spinach. Pkt. Io cts., oz. 20 cts., $1 / 41$ b. 55 cts., lb. $\$$ I.5o.

S. \& W. CO.'S SAVOY-LEAVED. A variety highly valued alike by market-growers and home-gardeners. The leaves are wrinkled and crumpled, resembling, to an extent, the Savoy cabbage. The variety is profitable on account of the heavy yield of produce, and it is particularly hardy. Pkt. Io cts., oz. I 5 cts., 1/4lb. 30 cts., 1 b. 75 cts.

VICTORIA LONG-STANDING. A variety suitable alike for spring and fall seeding. It is of low, compact habit; leaves shining dark green and heavily crumpled, forming a dense, flat rosette with very short petioles. Victoria is a great favorite with the market grower on account of the slowness with which it shoots to seed. Pkt. Io cts., oz. I5 cts., 1/41b. $30 \mathrm{cts}$.,

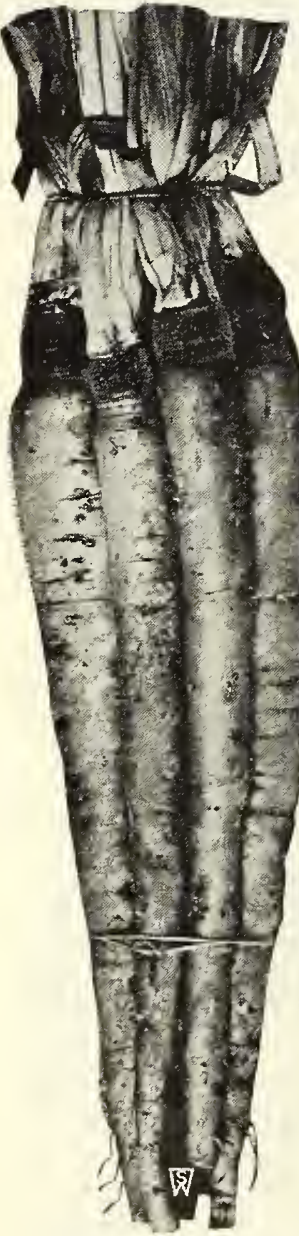

Mammoth Sandwich Island Salsify

\section{NEW ZEALAND SPINACH}

(Tetragonia expansa)

A half-hardy annual cultivated for its young leaves which form an excellent substitute for Spinach. The plants grow very vigorously, do not run to seed, and withstand drought much better than Spinach. New Zealand Spinach should therefore find a place in every garden, to furnish a summer supply of green boiled vegetables. It is recommended for use, also, on soils too poor to carry Spinach of the true type, as it grows naturally on dry upland situations.

CUlture.- Sow during May, in drills which should be at least 2 feet apart, as the plants spread rapidly. Thin to 9 inches between the plants in the row. Keep the surrounding soil well stirred and pinch off the young leaves and shoots freely as required, when others will be produced quickly in their place right through the summer. One seeding will suffice for a whole season, as the plants produce continuously until frost. IMPORTED SEED of high vitality and best quality. Pkt. Io cts., oz. 20 cts., $1 / 4$ lb. 55 cts., 1b. $\$$ I. 5 o.

\section{SWISS CHARD Spinach Beet}

One ounce will sow about 100 feet of drill

The plants are cultivated for the leaves which are used for "greens," the same as spinach or beettops; they are equal in quality and easier to prepare than spinach, and far superior to beets. Sow as early in spring as the ground can be worked, in rows I 2 inches apart, and thin out to 5 inches apart in the rows. As it grows, thin out for use. It can be used all summer when spinach is not available.

GIANT LUCULLUS. Plants of this variety grow to a height of 2 to $2 \frac{1}{2}$ feet. The stalks are quite thick, $I \frac{\pi}{2}$ inches broad. heavily ribbed and from Io to $\mathrm{I} 2$ inches long below the leaf. The extra-large leaves are sharply pointed at the top, while in texture they are heavily crumpled. The leafy portion of the foliage is cooked and served in the same manner as spinach. The leaves and stalks, served as separate vegetables, afford two distinct dishes from the same plant at one time. Pkt. Ioc. oz. 30 cts., $1 / 4$ lb. 75 cts., lb. $\$ 2$.

GREEN LYON. A vigorous-growing, stocky type with smooth, deep green leaves and broad, thick stalks. A very popular variety. Pkt. Io cts., oz. 25 cts., 1/4lb. 65 cts., lb. \$I.75.

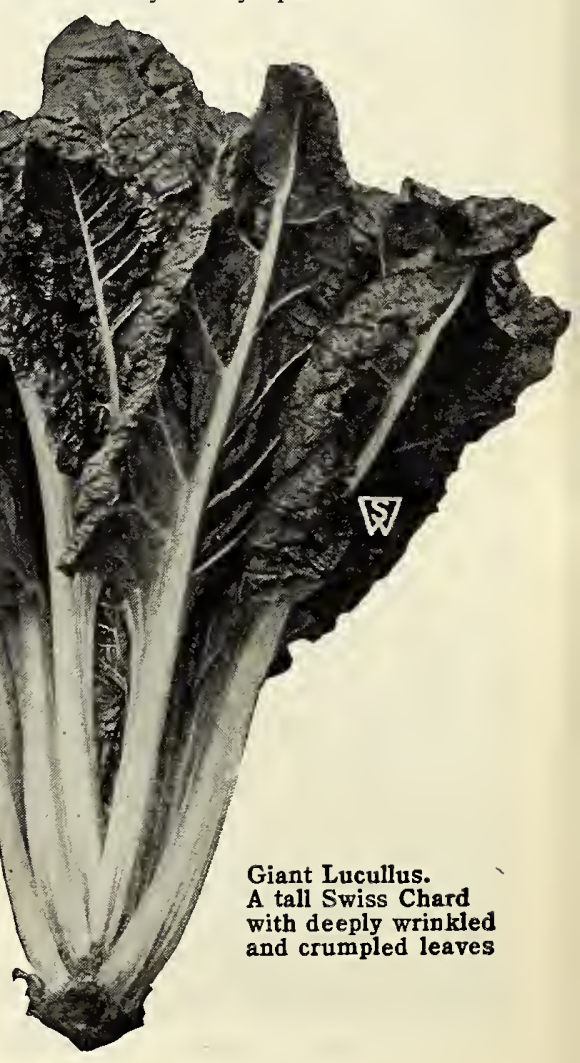




\section{TOMATO}

CUlTuRE.-The seed should be sown in a hotbed about the first week in March, in drills 5 inches apart and half an inch deep. When the plants are about 2 inches high, they should be transplanted into another hotbed and planted 4 inches apart, or planted in 4-inch pots, allowing a single plant to a pot. About the I5th of May the plants may be set out in the open ground 3 feet apart. Water freely at the time of transplanting. Sufficient plants for a small garden may be started by sowing a few seeds in a shallow box or flower-pot, and placing it in a sunny window of the room or kitchen. The fruit is greatly improved in quality if the vines are tied to a trellis or to stakes.

CHALK'S EARLY JEWEL. About a week later than Earliana. It is of uniformly large size; of brightest red, deep fruited and solid. Bears splendid large-sized Tomatoes throughout the season, and for quantity and quality of fruit it is easily without a rival among the best extra-earlies. Pkt. Io cts., $1 / 2$ Oz. 40 cts., oz. 65 cts., $1 / 4$ lb. $\$$ I. 75,1 b. $\$ 5$.

JOHN BAER. An early, bright red Tomato of wonderful quality. But little later than Earliana, it far surpasses that variety in size and quality; it is, further, one of the heaviest-yielding sorts we know. The flesh is solid, possessing a fine flavor, free from acid. The fruits contain remarkably few seeds, and in this connection it is interesting to note that for seed purposes we find it requires over seven bushels of hand-selected, perfect fruits to produce one pound of seed. This fact was somewhat of a surprise to us when harvesting our 1920 crop, and our supplies of this variety are short. The limited quantity which we have to offer is of a private stock and has been grown under our personal supervision. Pkt. I5 cts., $1 / 20 z$. $50 \mathrm{cts}$., oz. 90 cts., $1 / 4 \mathrm{lb}$. $\$ 2.75$, lb. $\$ 8$.

MATCHLESS. The color is rich cardinal-red. The skin is so tough that it is a splendid keeper and shipper, and is less liable to crack in wet weather than any other large Tomato. Unsurpassed for market or for table. The plant is a strong grower, and is very productive, bearing with undiminished vigor until frost. The fruit is free from core, and the seed-spaces are comparatively small. In flavor among the best. Pkt. Io cts., $1 / 2 \mathrm{Oz} .40 \mathrm{cts} ., \mathrm{oz} .65 \mathrm{c}$. $1 / 41$ b. \$I.75, 1b. \$5.

SELECTED STONE. By far one of the best of the main-crop red Tomatoes. It is smooth with very little core, and is not equaled by any other main-crop sort in its large yield of uniform-sized Tomatoes. Pkt. I 5 cts., oz. 65 cts., I/41b. $\$ 1.75,1 \mathrm{~b} . \$ 5$.

DWARF STONE. The fruits are produced in clusters of three to five, and, as the growth is close-jointed, each plant produces a large number. The Tomatoes average 4 inches in diameter and $2 \frac{1}{2}$ inches in depth. Its dwarf, compact habit suggests its use to all amateurs. Pkt. I 5 cts., 1/20z. $40 \mathrm{cts}$., oz. 65 cts., 1/4lb. $\$ 1.75,1$ b. $\$ 5$.

BONNY BEST. Considered among the best of the early sorts. The fruits are bright red in color, of medium size, and are produced in large quantities. Pkt. Io cts., 1/20z. 40 cts., oz. 65 cts., 1/41b. \$1.75, 1b. $\$ 5$.

PONDEROSA. Few Tomatoes equal this one in size and, while slightly ribbed, it is very solid and luscious for the family garden. The fruit is deep purple, oblong in form, generally ridged or ribbed with small seed-cells and frequently weighs one pound. Pkt. I5 cts., 1/20z. 60 cts., oz. $\$ 1,1 / 41 \mathrm{~b}$. $\$ 3.25,1 \mathrm{~b}$. \$IO.

\section{THE BEST YELLOW TOMATO}

GOLDEN PONDEROSA. The best large golden yellow Tomato. Smooth in appearance, of excellent quality, enormous size and ripens early. In shape very much like the Scarlet Ponderosa, but of a bright yellow color. Golden Ponderosa, served sliced and accompanied by a high-class scarlet variety, similarly sliced, presents an appetizing combination difficult to resist. Pkt. I5 cts., 1/20z. 60 cts., OZ. $\$$ I, I/4lb. $\$ 3,1$ b. $\$$ IO.

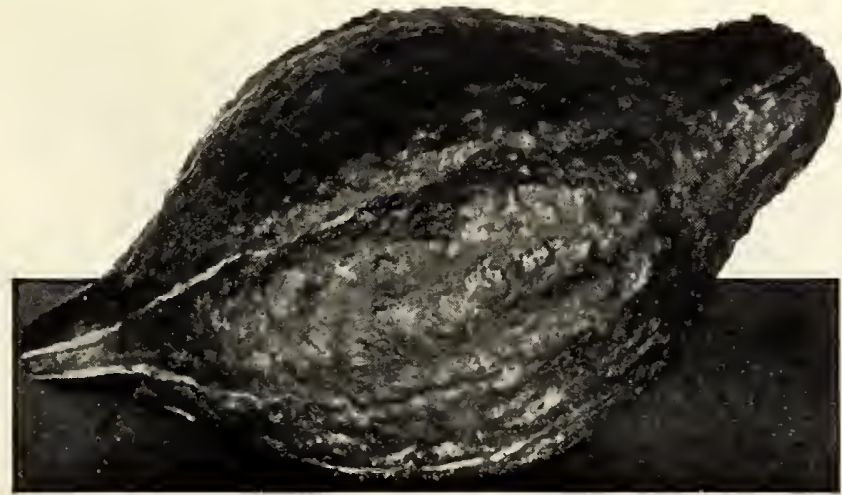

Hubbard Squash

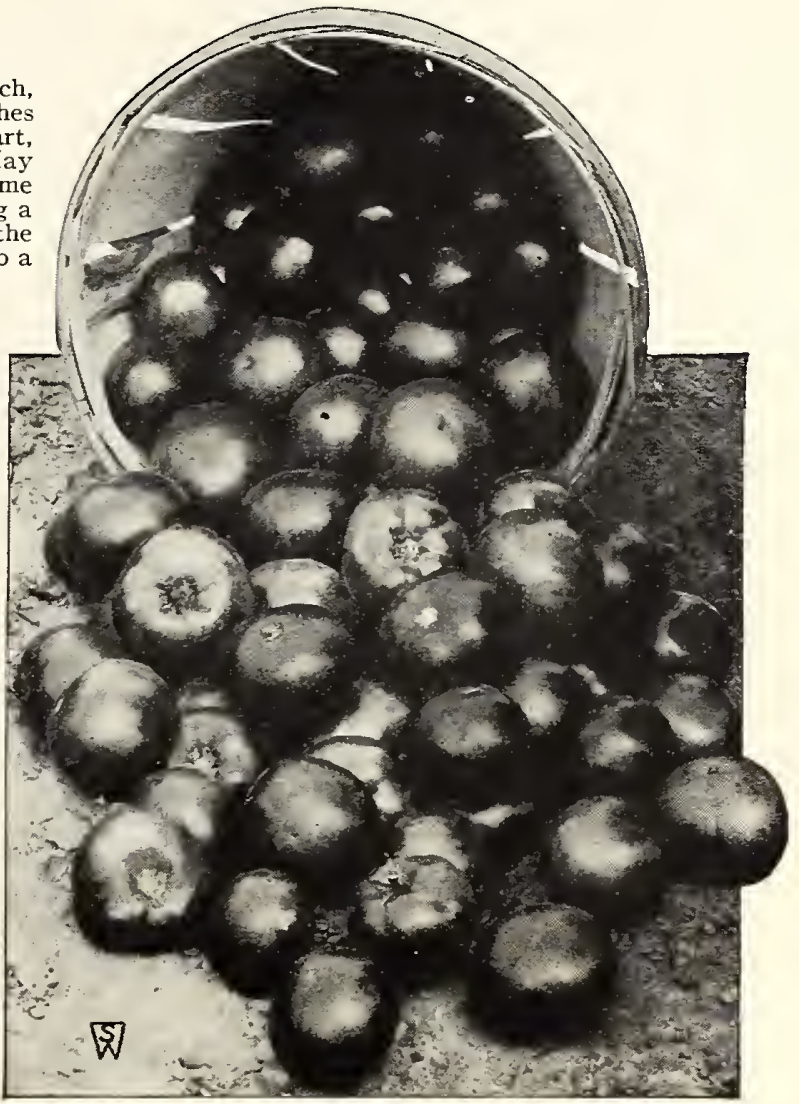

Chalk's Early Jewel Tomato

\section{SMALL-FRUITING TOMATOES}

The fruits of these are largely used for making fancy pickles, preserves, etc., while their size, shape, color, and flavor make them desirable additions to salads. The plants are extremely productive.

$\begin{array}{lll}\text { Yellow Cherry } & \text { Red Pear-shaped } & \text { Red Plum } \\ \text { Red Cherry } & \text { Yellow Pear } & \text { Yellow Plum } \\ \text { Red Currant } & \text { Peach } & \end{array}$

Above eight varieties: Pkt. $10 \mathrm{cts} ., 1 / 20 z .35 \mathrm{cts} ., 0 z, 60 \mathrm{cts}$. $1 / 4 \mathrm{lb} . \$ 1.75$

\section{SOUASH $\begin{gathered}\text { One ounce of Early Squash } \\ \text { will plant about } 25 \text { hills }\end{gathered}$}

Culture.-The Squash succeeds best in good rich soil. It is not advisable to plant before May I5. Sow in hills in the same manner as cucumbers and melons.

LONG ISLAND WHITE BUSH. A selection of the old

White Bush Scalloped, and a vast improvement upon it, having less prominent ridges and being much deeper, so that a single Squash actually contains nearly twice as much weight for the same cubic measurement as the old sort. In addition to this, it is of finer quality and very prolific. We can strongly recommend this variety. Pkt. Io cts. oz. 30 cts., $1 / 4$ Ib. 75 cts., 1 b. $\$ 2$.

GIANT BUSH SUMMER CROOKNECK. The Crookneck class of Squash surpasses in quality any of the summer varieties, and in the Giant Bush we have the delicious buttery flavor of the original sort, but of just double the size. Pkt. Io cts., oz. 25 cts., 1/4lb. 65 cts., lb. \$1.75.

HUBBARD. Bluish green color, occasionally marked with brownish orange. Will keep from September to May. Pkt. Io cts., oz. $30 \mathrm{cts}$., 1/4lb. 75 cts., lb. $\$ 2$.

BOSTON MARROW. A very popular Squash for fall or winter use. Bright orange color, flesh yellow; oval in form. A splendid keeper and excellent for pies. Pkt. Io cts. oz. 30 cts., I $/ 4$ lb. 75 cts., Ib. $\$ 2$. 


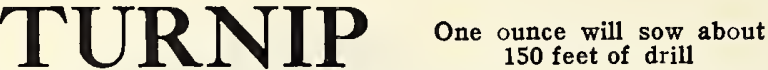

Culture.-For early Turnips, sow as soon as the ground opens in spring. Rutabagas should be sown from any time in July to first of August; but the other kinds, for winter use, may be sown from the middle of July to the end of August. Turnips are generally sown broadcast, but much larger crops are obtained (particularly of the Rutabagas) by cultivating in drills 18 inches apart, and thinning to 6 inches in the drill. Sow in drills, one pound to the acre; broadcast, two to three pounds to the acre. EARLY WHITE MILAN. As early as the Early Purple-Top Milan and possessing all of its good qualities. The entire "bulb," inside and out, is clear ivory-white in color; the outer surface is perfectly smooth. It grows so quickly that even the outer surface of the "bulb" is quite tender. Its table qualities are unequaled, being of the most delicate flavor and tempting appearance. Pkt. Io cts., oz. 30 cts., $1 / 4$ lb. 75 cts., lb. $\$ 2$.

PURPLE-TOP WHITE GLOBE. This variety may be grown to quite a large size, without developing signs of coarseness. It is of spherical shape, the skin white with the upper one-third colored reddish purple. The flesh is pure white, firm, fine-grained, and of superior flavor. A haudsome looking bulb, rapidly taking the lead of all other varieties of early Turnips for market and home-gardening purposes. It is one of the best sorts to store for winter, and, in addition to its fine table qualities, it is excellent and economical for stock-feeding. Pkt. Io cts., oz. 20 cts., I $/ 41$ b. 45 cts., lb. $\$ I .25$.

SNOWBALL. An excellent first-early, globe-shaped root; smooth, clean, and free from all coarseness. A variety that is recommended particularly to the homegardener on account of its splendid table qualities. Pkt. Io cts., oz. $20 \mathrm{cts}$., $1 / 4 \mathrm{lb}$. 55 cts., 1b. \$I.50.

RED-TOP STRAP-LEAF. A very popular type, maturing in about two months from sowing. The roots are flat, marked with reddish purple on the upper portion; the flesh is pure white and of fine quality. Pkt. IOc., Oz. 2Oc., 1/4lb. 45C., Ib. \$I.25.

GOLDEN BALL, or ORANGE JELLY. This is the most distinct yellow Turnip we know. The flesh is of a very fine texture, making it one of the best table varieties. Its beaut:ful color and fine flesh have earned for it the synonym of "Orange Jelly," which well describes its appearance when ready for the table. The bulb is of medium size, with small taproot, and is early in maturing. Pkt. Io cts., oz. 20 cts., $1 / 4$ lb. 55 cts., lb. \$I.50.

\section{MANGEL-WURZEL}

Culture.-Sow in drills during May or June, about 2 feet apart; thin out to 9 to 12 inches in the rows. Six to 8 pounds are required for one acre.

MAMMOTH LONG RED. The roots are of enormous size, very regular and clean, with but small top-growth. The skin is bright, rich red, and the roots, which frequently exceed 2 feet in length, grow from one-half to two-thirds above the ground. Oz. I 5 cts., 1/4lb. 30 cts., 1 b. 85 cts., Io lbs. $\$ 8$.

GOLDEN TANKARD. Smooth, yellow flesh; small, yellow-stemmed top; length I I inches, diameter 4 inches, shape cylindrical. Usually grows half out of the ground. Easily pulled, good yielder; very hardy and nutritious. $1 / 41 \mathrm{lb}$. 40 cts., lb. $\$$ I, Io lbs. $\$ 9$.

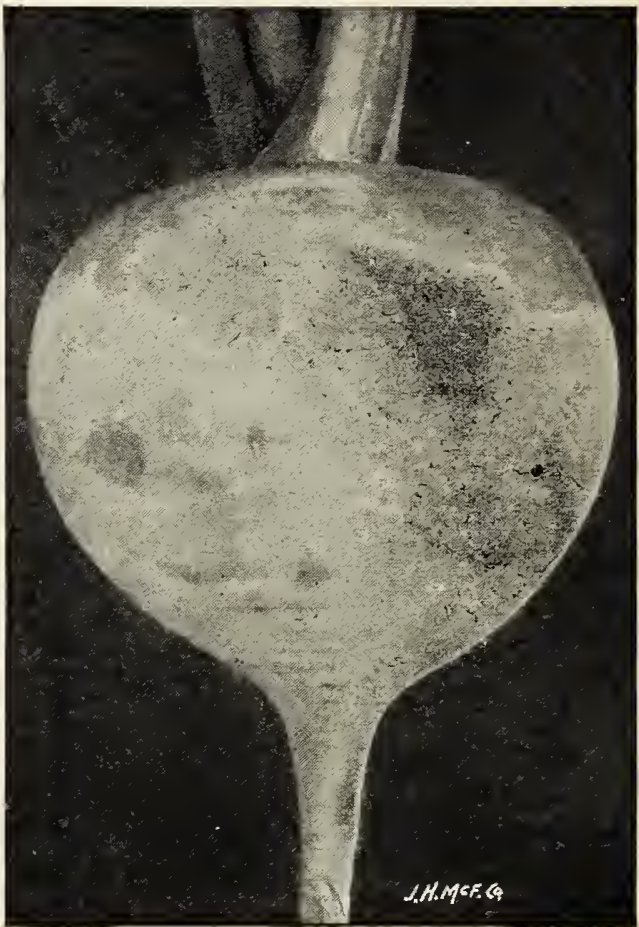

Purple-Top White Globe Turnip

\section{RUTABAGA ( $\left.\begin{array}{c}\text { Russian or } \\ \text { swedish Turnip }\end{array}\right)$}

S. \& W. CO.'S LONG ISLAND IMPROVED. This special strain of Rutabaga is grown on Long Island by a very careful grower. It is of a remarkably uniform shape and fine quality, and is also a splendid keeper. It grows to a large size, the skin is smooth, and flesh is beautiful yellow and finegrained. Pkt. Io cts., Oz. 20 cts., I/4lb. 45 cts., lb. $\$ 1.25$.

\section{Aromatic, Medicinal and Pot Herbs}

\section{Arnica (Arnica montana). Valuable medicinal quali-}

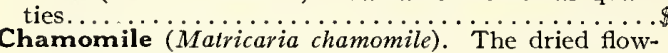

ers possess medicinal qualities. Prescribed as an emetic and vermifuge.

Dill (A nethum graveolens). Seed used for flavoring vinegar....................... $\ldots \ldots \ldots$ ldb. 65c..

Lavender (Lavandula vera). True. For oil and distilled water.

\section{Pkt. Oz.}

Marjoram

(Origanum Majorana). Sweet. Used in

Rosemary (Rosmarinus officinalis). Yields an aromatic oil and water................................. also used in medicine. Com

Savory (Satureia hortensis). Summer. Used as a culinary herb.......................................

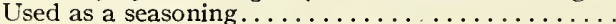

Pkt.

I5 \$O 50

I5 50

I5 50

I 540

I5 75

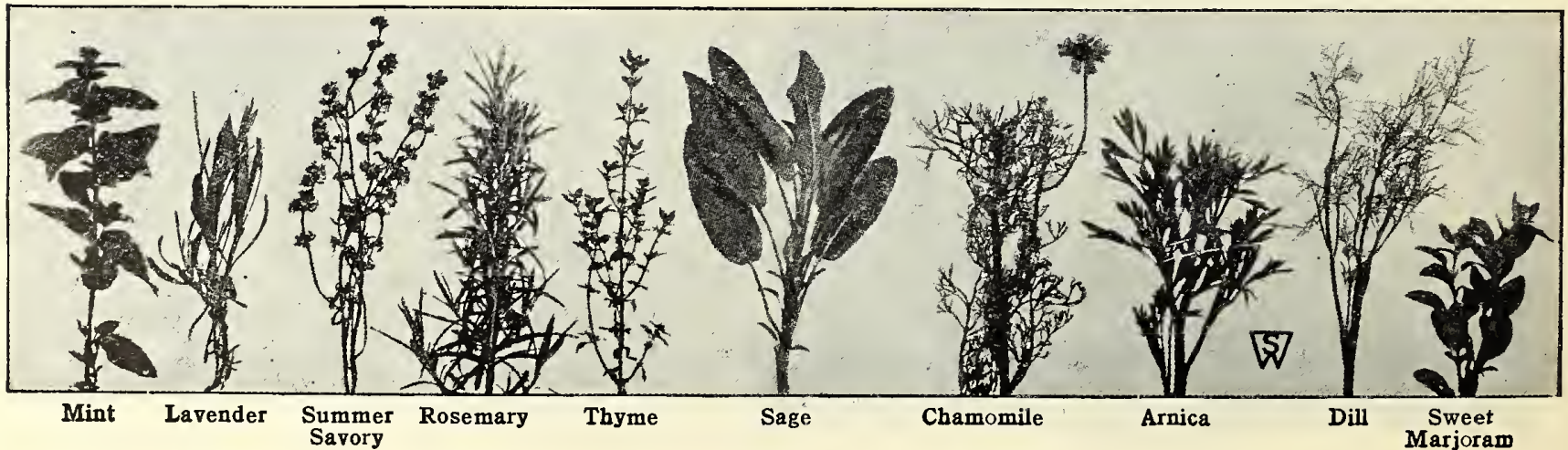



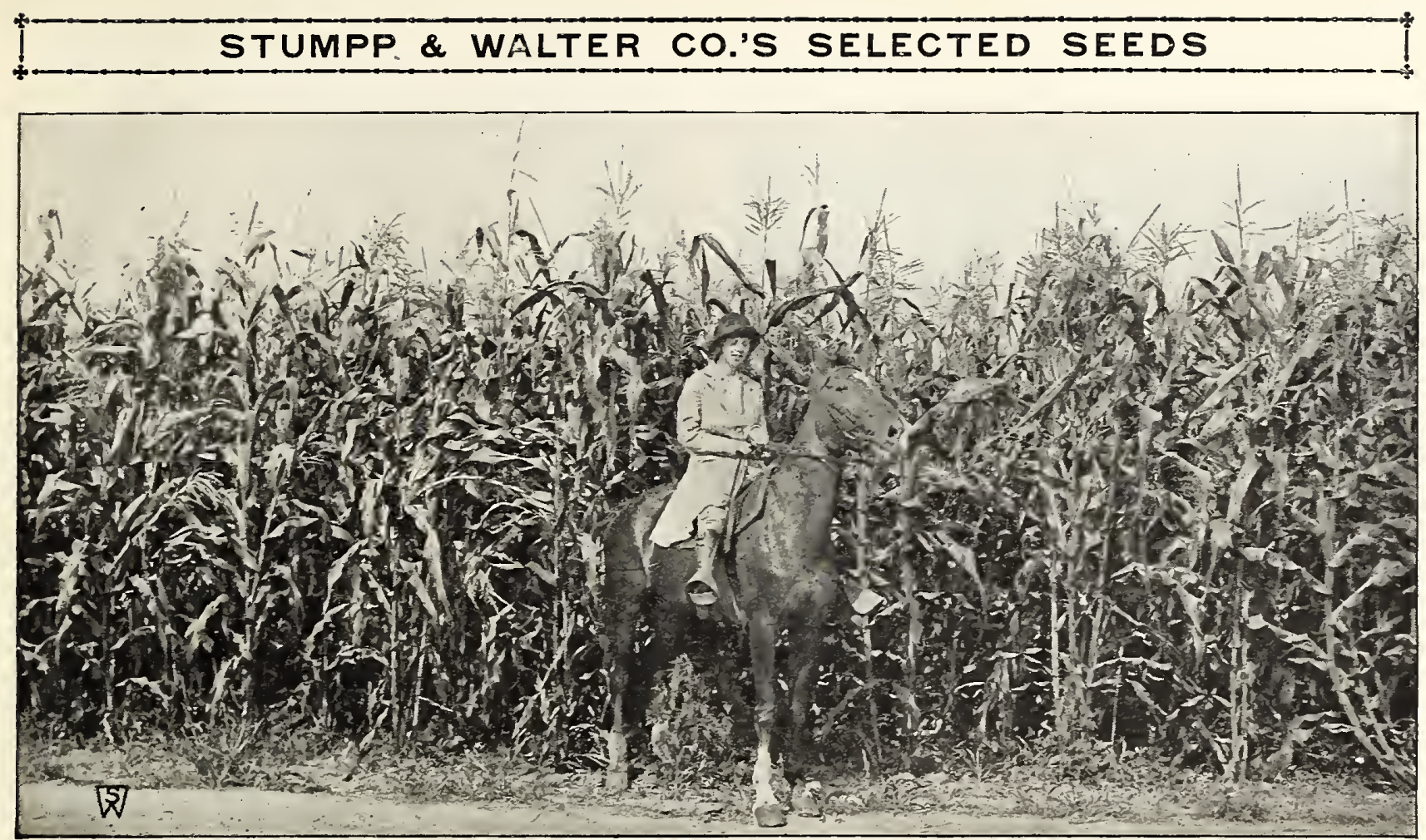

A Field of S. \& W. Co.'s New Golden Eureka Yellow Dent Corn (Improved Leaming), showing vigorous growth

\section{S. \&W.CO.'S SELECTED STRAIN OF FIELD CORN}

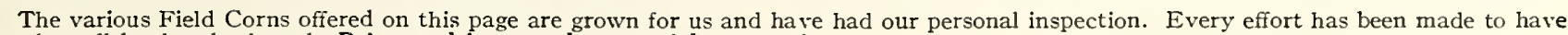
stocks well bred and selected. Prices subject to change without notice.

\section{New Golden Eureka Dent Corn (IMPROVED LEAMING)}

This magnificent Field Corn is a decided improvement on the popular variety, Eureka, being fully ten days earlier. It is a tremendous yielder. We have had reports of yields of over I 50 bushels of shelled Corn to the acre. The plants grow from I2 to I5 feet high, a great proportion of them bearing two ears to the stalk, the ears averaging I 2 to 15 inches long, with I 8 to 22 rows of deep rich yellow grains and small cob. Seventy pounds of ears frequently yield 60 pounds of shelled Corn. While not so quick to mature as a Flint Corn, where Ioo days of "Corn weather" are assured, it is the best Corn to grow. A very fine variety for ensilage, and frequently produces 25 tons of good Corn silage per acre. Qt. 25 cts., postpaid $40 \mathrm{cts}$.; pk. \$I.5o, bus. $\$ 5$, Io-bus. lots, $\$ 4.50$ per bus.

\section{Jumbo Silage Corn}

A first-class ensilage variety. Grows I2 to I5 feet high, with mammoth stems in proportion, and an enormous growth of leaves. Under favorable conditions it will produce ears a foot or more long yielding two of them to a plant. Jumbo Silage Corn is recommended for rich, low lands, when an enormous bulk of fodder may be expected. Qt. 3Oc., postpaid 45 c.; pk. $\$$ I.5O, bus. $\$ 5.25$, Io-bus. lots, $\$ 4.75$ per bus.

\section{Early Smoky Dent}

The earliest Dent Corn in cultivation. Many growers claim that it has every variety of Corn surpassed for early maturity, large size of ears and splendid quality; ears are 8 to Io inches long and have I 2 to I6 rows of kernels on the cob. Stalks average, on good ground, 8 feet or more, and it matures generally in about 80 days from date of planting. It is thus a splendid dual-purpose Corn, valuable both for crib and silo purposes. Qt. $25 \mathrm{cts}$., postpaid $40 \mathrm{cts}$; pk. $\$ \mathrm{I}_{5} \mathrm{O}_{\text {, }}$ bus. $\$ 4.50$, Io-bus. lots, $\$ 4.25$ per bus.

\section{Evergreen Fodder}

A variety of the Sweet Corn especially valuable as green fodder Sow broadcast, 2 bushels to the acre; in drills 3 feet apart, I bushel per acre. Qt. 35 cts., postpaid $50 \mathrm{cts}$; pk. $\$ 1.75$, bus. $\$ 6$, Io-bus. lots, $\$ 5.50$ per bus.

\section{Improved Early Horsetooth}

Same as Southern Horsetooth, but better selected and earlier. Small stalks; large quantity of foliage. Qt. $25 \mathrm{cts} .$, postpaid $40 \mathrm{cts}$; pk. $\$$ I.35, bus. $\$ 4$, Io-bus. lots, $\$ 3.50$ per bus.

\section{SOY BEANS}

Especially valuable for mixing with corn for silage, for the production of hay, and for use as pasture, especially for hogs. The growth is erect, and they are therefore easily harvested. They are also valuable as a crop for plowing under for green manure, to add humus and nitrogen to the soil. They can also be planted with cowpeas, and on account of their erect growth they support the vines of the cowpeas.

Mammoth Yellow Soy Beans. Qt. $30 \mathrm{cts}$. postpaid $40 \mathrm{cts}$; $\mathrm{pk}$. \$I.35, bus. $\$ 4$; I0bus. lots, $\$ 3.85$ per bus.

\section{COWPEAS}

Used for improvement of soils by plowing under; also makes valuable hay, when sown alone or with soy beans, during May, June, or July, at the rate of two bushels to acre or one bushel of soy beans and one of Cowpeas, broadcast or in a wheat-drill.

Whippoorwill. An early, bunch-growing Pea; has brown-speckled seed. Qt. 30 cts., postpaid 40 cts.; pk. $\$$ I. 65 , bus. $\$ 5$.

New Era. Not quite so large as Whippoorwill, but earlier. Qt. $30 \mathrm{cts}$., postpaid 40c.; pk. $\$ 1.65$, bus. $\$ 5$.
CANADA FIELD PEAS

"Peas could be made to bring more nitrogen to the soils of this country every year than is now purchased annually by the farmers at the cost of millions of dollars." learbook of the U. S. Department of Agriculture.

Peas are a paying crop and can be profitably planted in many ways. Qt. $35 \mathrm{cts}$., postpaid 45 cts.; pk. $\$$ I.75, bus. $\$ 5.50$, IObus. lots, $\$ 5.25$ per bus. On orders of 1 oo bus. or over, prices on application.

When sown alone about three bushels are required to the acre. 


\section{STUMPP \& WALTER CO., 204-206 N. EUTAW ST, BALTIMORE, MD.}

TR PRICES ON GRASS AND CLOVER SEED ARE SUBJECT TO CHANGE

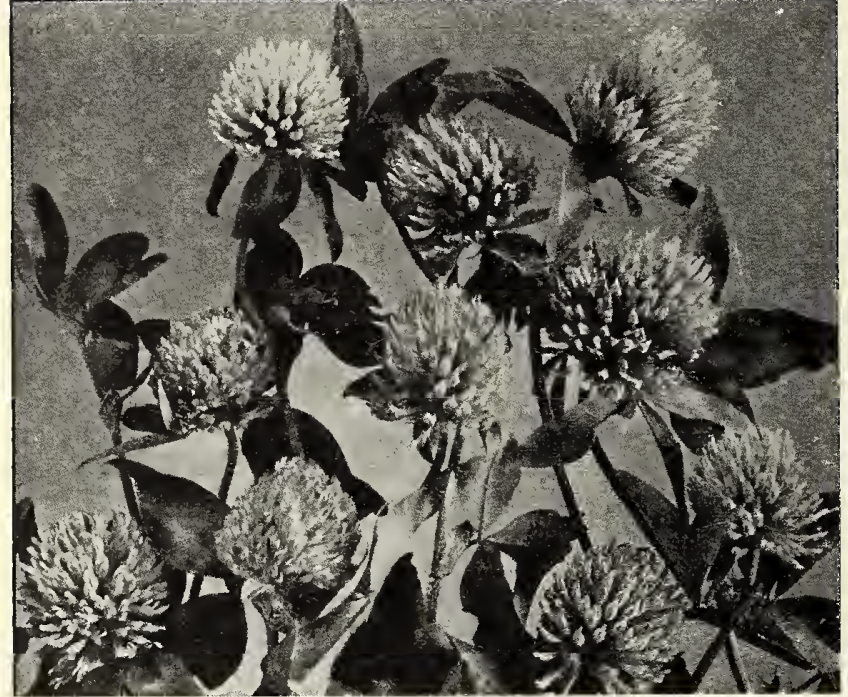

Medium Red Clover

\section{Medium Red Clover}

\section{Trifolium pratense}

This is regarded as the most valuable of the Clover family. It makes two crops each year. The first is usually cut when it is in blossom for hay; the last crop may be harvested for seed, cut for hay or plowed under to add fertility to the soil. It may be sown either in the spring or fall, and if no other grasses are used, at the rate of from ten to fifteen pounds to the acre, according to quality of seed used and condition of the soil. Clover adds greatly to the fertility of the land on which it is grown. It does not exhaust the soil, but enriches it. It pays always to buy the best grade of Clover seed which can be obtained. Lb. $65 \mathrm{cts}$., postpaid $75 \mathrm{cts}$; I I lbs. $\$ 5.50$, Ioo lbs. $\$ 45$.

\section{White Bokhara, or Sweet Clover Melilotus alba}

Farmers are sowing this Clover to quite a considerable extent on light, sandy land, where other Clovers do not take well. They hope, by sowing this Bokhara Clover, to get a good growth to turn under to improve the land and also to inoculate the soil so that it will produce good crops of Crimson Clover and Alfalfa from seedlings of these to follow the Bokhara. For feed or forage it should be cut when young, for when it gets old, cattle do not relish it, and it is not of very high nutritive value. It is also largely used for sowing for bees. Lb. 30 cts., postpaid $40 \mathrm{cts}$; ; Io lbs. $\$ 2.50$, Ioo lbs. $\$ 20$.

\section{Hungarian Millet}

For good low grounds on rich soil, this makes even a more valuable crop than German Millet. Sow from the first of May to the end of July at the rate of I bushel per acre. Bushel weighs 48 pounds. Lb. 20 cts., postpaid $30 \mathrm{cts}$; Io $1 \mathrm{bs}$. \$I.10, roo 1bs. \$9.

\section{Seed Oats}

For grain, $2 \frac{1}{2}$ bushels to the acre; for forage, 3 bushels, or, with Canada Peas, 1 to $1 \frac{1}{2}$ bushels

Sold at the standard weight of 32 pounds to the bushel. Often the variety offered below will weigh up to 40 pounds to the measured bushel, but all Oats are purchased and sold at the standard weight of 32 pounds to the bushel.

Welcome Oats. One of the heaviest, handsomest, and most productive white varieties grown: It stools heavily, with extra-strong. straight straw, standing well. Succeeds well in a wide range of climate, and under a great variety of soils and methods of culture. Pk. 65 cts., bus. ( 32 lbs.) $\$ 1.80$, to bus. $\$ I 7$, I0o bus. $\$ 1.55$ per bus.

\section{Alfalfa or Lucerne}

Alfalfa possesses a wonderful root-system, deep and strong; consequently it is a great drought-resister. The plant increases soilfertility by transforming the free nitrogen of the air into soluble nitrates; and as a plow-in crop it is excellent, adding materialiy to the humus in the soil. Our seed is obtained from those sections where Alfalfa has endured the extreme cold of winter in high altitudes. Lb. $50 \mathrm{cts} .$, postpaid $60 \mathrm{cts}$; ; Io lbs. $\$ 4.50$, I00 lbs. $\$ 35$.

\section{Grimm Alfalfa}

There is some disagreement among investigators as to how Grimm Alfalfa obtained its hardiness, but there is no difference of opinion that it is hardy. From the appearance of the seed, this Alfalfa cannot be distinguished from other varieties; the root-system, however, is more branched. Because of this root-system, we believe it will grow well over a hardpan soil, and is adapted to a wetter soil than the other Alfalfa. We recommend I5 pounds of the seed, sown broadcast, to the acre, as its stooling habit requires less seed to be sown than other Alfalfa offered. The quantity of seed of this variety obtainable is limited and we offer it subject to being unsold. Lb. 80 cts., postpaid 90 cts.; Io lbs. $\$ 7.50$, 100 lbs, $\$ 65$.

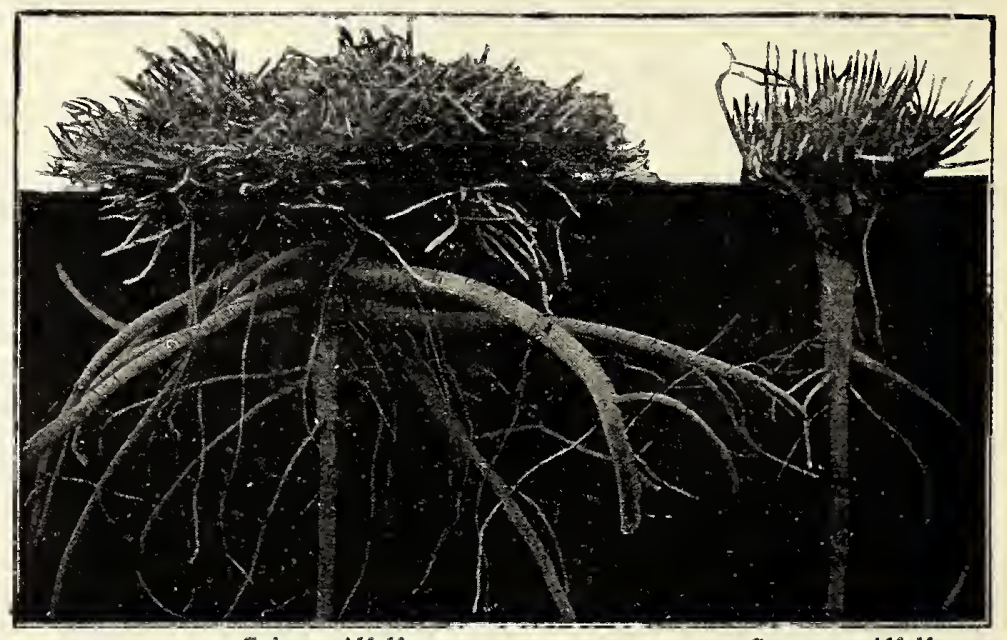

Grimm Alfalfa

The Griman in comparison with common Alfalfa. This photograph was furnished by Prof. Philo K. Blinn, Alfalfa Specialist of the Experiment Station at Fort Collins, Colorado, showing typical Alfalfa plants grown under exactly the same conditions.

\section{Natural Grasses}

Bermuda Grass. Superfine quality ........ $\begin{aligned} & \text { Lb. } 60 \\ & \$ 45\end{aligned}$ Carpet Grass......................... $55 \quad 4000$

South German Bent, Genuine Imported. Fine. I 50 II 00

Italian Rye Grass................... 30 20 00

Kentucky Blue Grass, Fine Recleaned..................... 655 50 00

Orchard Grass....

Special quotations furnished on quantity lots

Pacey's English Perennial Rye Grass....... Lo 35 Ioolbs.

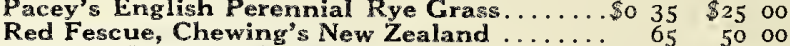
Redtop, Fancy Recleaned................... $45 \quad 3250$

Rough-stalked Meadow Grass.................. 80 . 65 oo

Sudan Grass ........................ 20 10

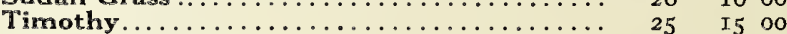

These prices of Field Seeds subject to change without notice. All orders in large quantities subject to confirmation of Bouse 

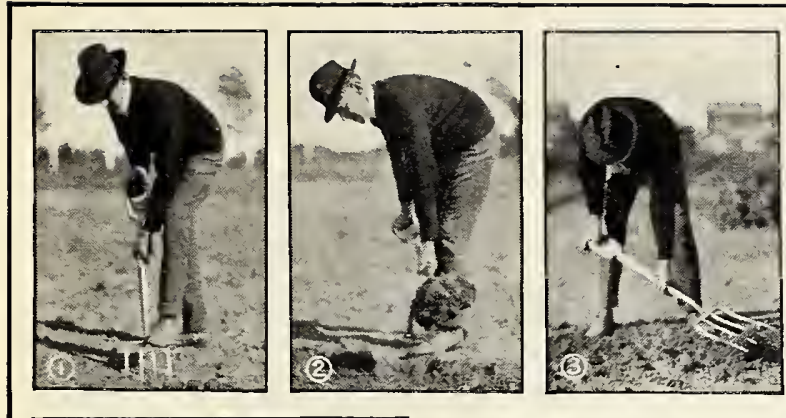

\section{How to Make a Lawn}

\section{With"Staigreen" Grass Seeds}

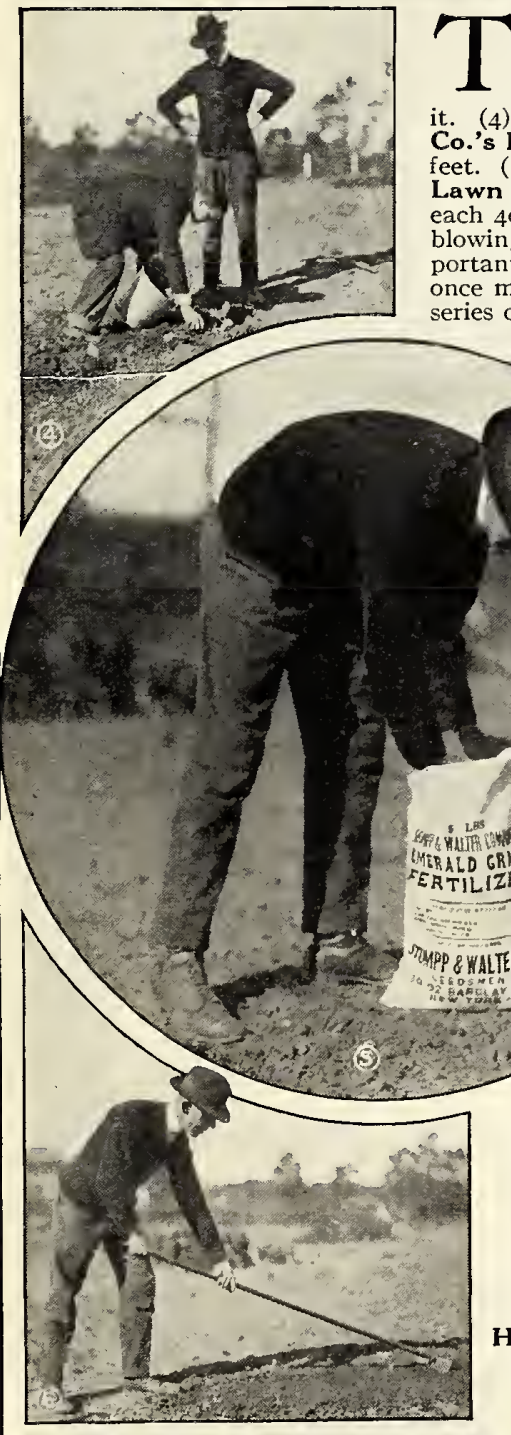

HE production of a good lawn is not at all difficult. The method is as follows: (I) Dig the soil about 6 inches deep, but only when it is dry; if rain has fallen recently allow a few days of fine
weather to elapse before commencing work. (2) As you dig, lift each clod high enough to enable you to turn it completely over. (3) Strike the inverted clod with the back of the fork to break it. (4) As the work proceeds, remove all stones, sticks, and rubbish. (5) Scatter Stumpp \& Walter Co.'s Emerald Grass Fertilizer on the dug earth; use I ton per acre or I pound to each 25 square feet. (6) Draw a rake back and forth until the soil is smooth and in fine condition. (7) Sow Staigreen Weed at the minimum rate of Ioo pounds per acre ( 4 bushels) or I pound (nearly 2 quarts) to each 400 square feet. Double the quantity when turf is needed quickly. Select a day when no wind is blowing; divide the seed into two portions and sow the land twice to insure its even covering; it is imto stir the contents of the bag now and again. When you have sown the seed, rake the land once more, but very lightly. Do not work the rake back and forth-merely draw it toward you in a
series of light strokes, raking only once in the same place. The idea is to bury most of the grass seeds no more than $1 / 8$ inch deep. (8) Roll the seeded area, but should rain fall before the work is completed, defer the rolling until the land has dried. How long will the Lawn be
growing? This varies with the time of year, quality of soil, favorable conditions the y o ung seedlings s how through in less than ten days and the whole area looks green in a further two weeks; wait four weeks more before walking on the grass except to mow and roll it.

When is the best time to make a Lawn? Early spring and late summer are the best, but seed will grow quite well if sown except during July.

Will the above directions hold on poor or sandy land? Before commencing work on poor soil, spread rotted horse-manure or cow-manure over the land at the rate of 20 tons to the acre or I pound per square foot. Then proceed exactly as directed. If manure cannot be procured, use Pulverized Sheep Manure at the rate of 2 tons to the acre or I pound to each Io square feet. Do not attempt to grow a lawn on excavated soil, subsoil, or "fill" without first applying manure, digging, then adding at least an inch of topsoil, two or three if possible. Apply Emerald Grass Fertilizer, and proceed as suggested.

How about moist, sour soil? Spread hydrated lime at the rate of 2 tons per acre or I pound to each Io square feet; then follow directions. In bad cases it will be necessary first to drain the land by digging ditches and laying tile.

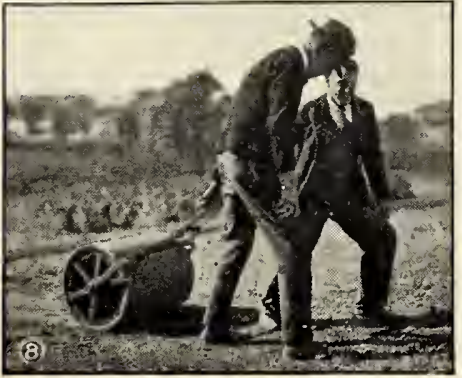

What after-care is needed? As soon as the young grass is 2 inches high, begin cutting it and keep it regularly mown; roll it at least once a week, and water during dry weather.

How about Weeds? Stumpp \& Walter Co.'s seeds are as free from weeds as care and modern machinery can make them. All soils. however, contain seeds of weeds-some more than others - and many of these start to grow along with the grass. Close cutting will kill most of them, but the few that remain must be taken out, and the holes filled with good soil in which you have mixed some grass seeds.

How about White Clover? We include Clover only in our lowest-priced mixture, which we call "High Grade Lawn Seed," because Clover is generally omitted nowadays in the finest lawns. For the convenience of our customers who wish it, we offer Superfine White Clover. Oz. Ioc., $\$ / 4 \mathrm{lb}$. 20c., $1 \mathrm{~b}$. $65 \mathrm{c}$., Io lbs. $\$ 6$, bus. (6o lbs.) $\$ 33$, Ioo lbs. $\$ 55$. Mixed with grass seeds, usual allowance of clover is 5 per cent. Is "Staigreen" the best seed to use? No seeds are purer and no seeds grow more vigorously than the grass seeds in Staigreen, which is a mixture of five distinct varieties, and for the finest lawns around the residence Staigreen cannot be surpassed. For shade and special conditions use the mixtures described on the following pages. Staigreen Lawn Mixture, packed in I-lb. sifter-top container, 65 cts., $21 / 2$ lbs. $\$ 1.55,5$ 1bs. $\$ 3,121 / 2$ lbs. $\$ 7.25,25$ lbs. $\$$ I 4 , IOo lbs. $\$ 55$.

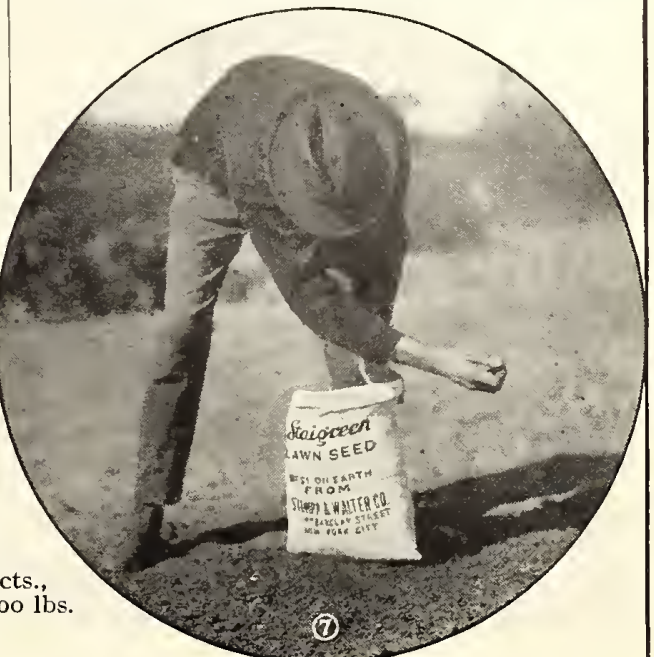




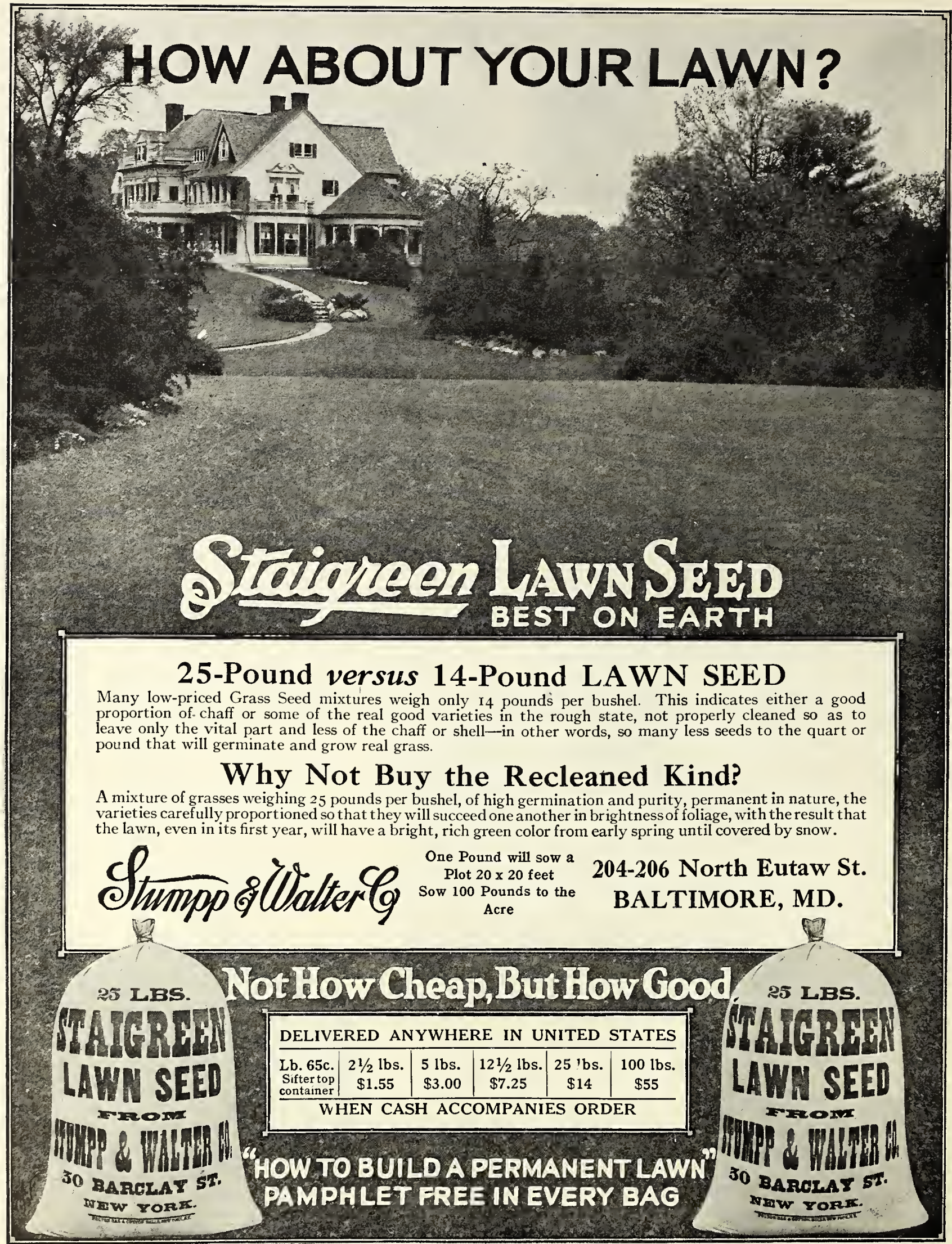




\section{SHADY PLACE LAWN SEED}

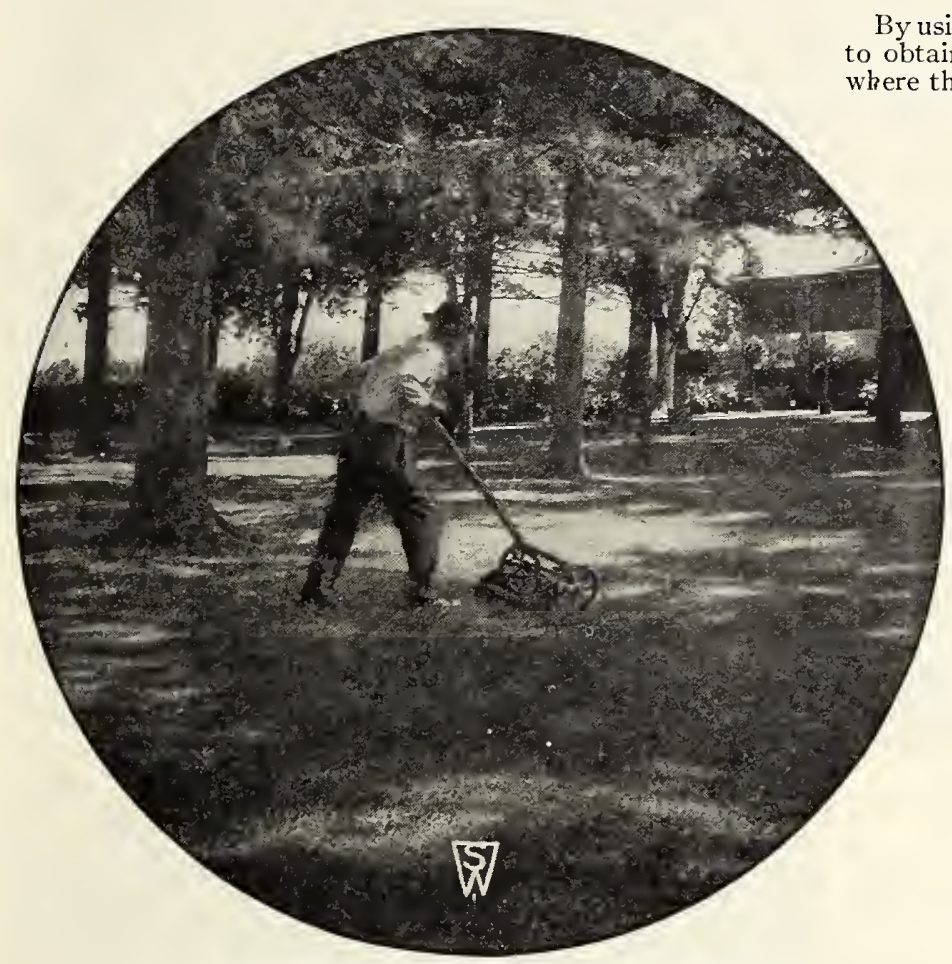

S. \& W. Co.'s Shady Place Lawn Grass

By using the correct seed varieties it is generally not at all difficult o obtain a good turf under trees. In particularly stubborn cases, where the shade is very dense, it is desirable to add lime every fall, dig lightly every spring, apply Pulverized Sheep Manure, rake and sow Shady Place Lawn Seed. A lawn under trees is the most beautiful of all. S. \& W. Co.'s Shady Place Lawn Seed will produce it. Use as a minimum allowance one quart for each I 5 by I $_{5}$ feet or 4 bushels per acre; sow at half these rates when renovating a lawn.

Qt. 60c., 4 qts. $\$ 1.90,8$ qts. $\$ 3.50,1 / 2$ bus. $\$ 6.25$, bus. $\$ 12,10$ bus. $\$ 115$. Charges prepaid when cash accompanies order. Weight 20 lbs. per bushel.

\section{The Best Two Lawn Dressings}

For use when preparing land for grass or feeding established turf.

EMERALD GRASS FERTILIZEP. 5 lbs. $50 \mathrm{cts}$.,

Io lbs. 90 cts., 25 lbs. \$I .75 50 lbs. $\$ 3.25$, Ioo lbs.

$\$ 5.50,500$ lbs. $\$ 22$, ton $\$ 75$.

PULVERIZED SHEEP MANURE. $5 \mathrm{lbs}$. $40 \mathrm{cts.}$

Io lbs. 60 cts., 25 lbs. $\$ 1.25,50 \mathrm{lbs}$. $\$ 2$, I00 lbs. $\$ 3.50,500$ lbs. $\$ 15$, ton $\$ 50$.

Apply Emerald Grass Fertilizer, which is a mixture of chemicals, either spring, summer, or early fall; on new land use one ton per acre or one pound to each 25 square feet. Use Pulverized Sheep Manure, in addition, on land which is sandy, poor, and deficient in humus, at the rate of two tons per acre or two pounds to each 25 square feet-you may with safety dig in sheep manure in larger quantities. For nourishing established lawns, one-half the above allowances may be used.

\section{SOUTHERN LAWN SEED}

From central Virginia south the ordinary northern grasses will not thrive permanently, and good results are not likely to follow the use of the customary mixtures. As a result of an intimate knowledge of southern conditions we offer a special formula which we find is highly satisfactory. We advise that two seedings be made, one in spring and one in fall, allowing at each seeding one quart to each 15 by 15 feet or 4 bushels to the acre. Give a seeding each subsequent spring and fall of one-third the above proportions.

Qt. 45 cts., 4 qts. $\$ 1.50,8$ qts. $\$ 2.75$, $1 / 2$ bus. $\$ 4.75$, bus. $\$ 9,10$ bus. $\$ 85$. Charges prepaid when cash accompanies order. Weighs 20 pounds per bushel.

"Golf Turf" contains pages of on the difficulties of producing turf under trees; also regarding the growing of grass in the Southern States. It is free, and we suggest that you write for a copy.

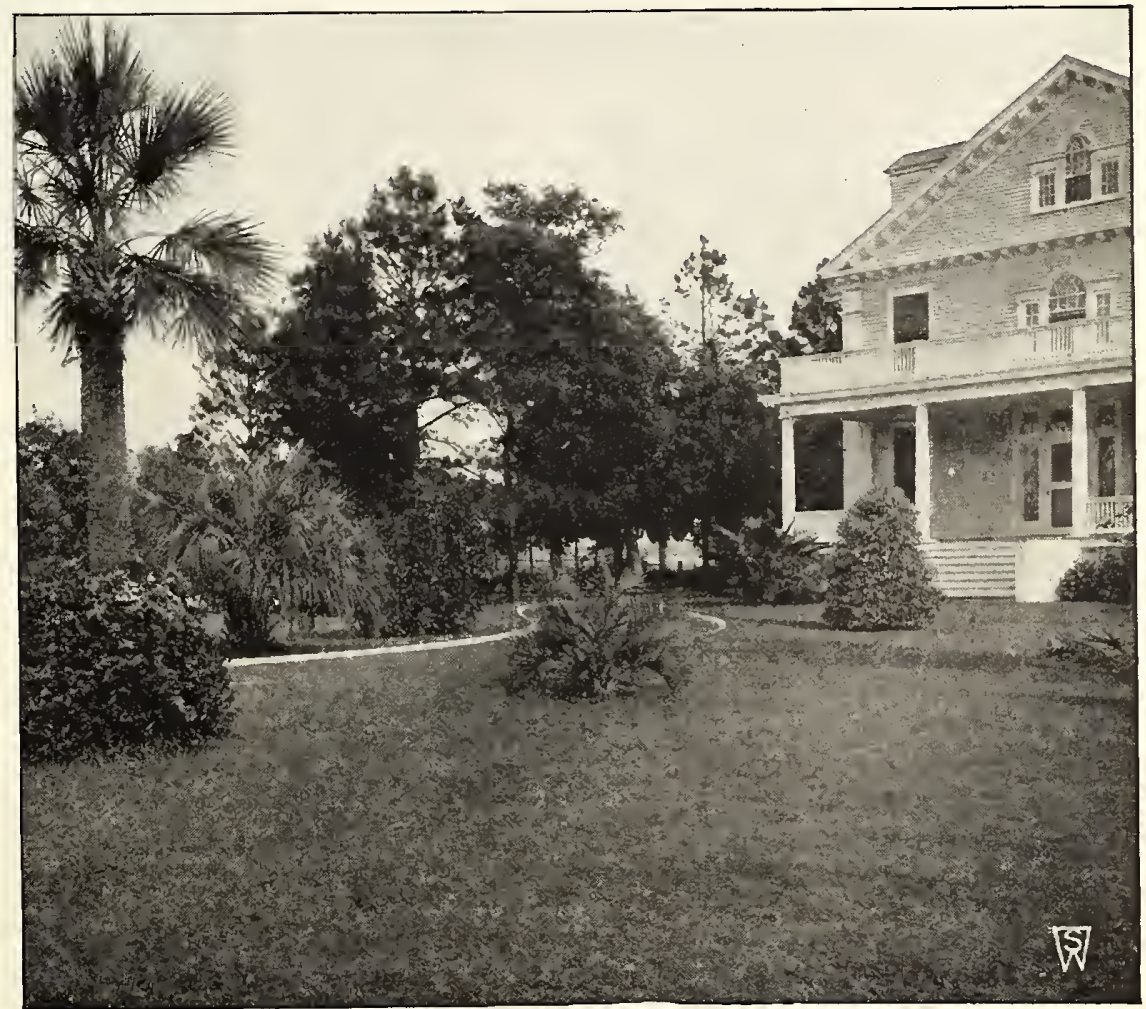

S. \& W. Co.'s Southern Lawn Grass 


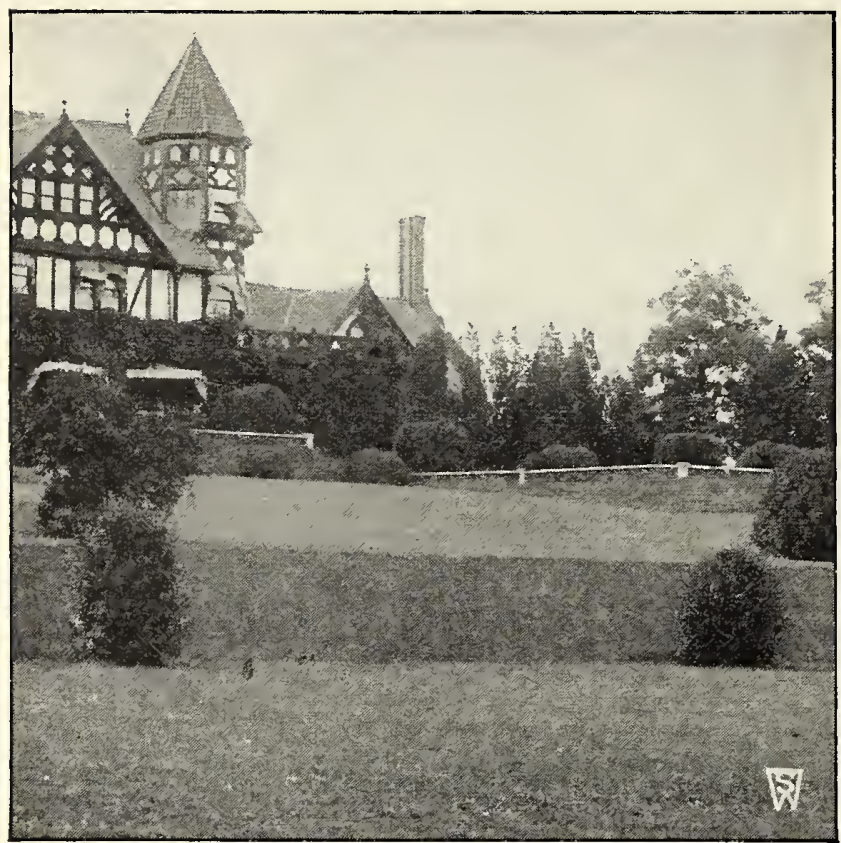

Stumpp \& Walter Co.'s Terrace Sod Lawn Grass

\section{SEASHORE LAWN SEED}

The varieties of which this mixture is compounded are selected for their deep rooting qualities, resistance to salt spray, and high winds. It is recommended for those situations on the ocean front where difficulty has been experienced in getting a lawn with the usual grass seeds. The soil in the neighborhood of the sea is frequently very poor, and a very good preparation for seed is to apply Pulverized Sheep Manure at the rate of $1 / 2$ to I pound per square yard; rake after applying this manure and then sow seed.

One or more quarts of Seashore Lawn Seed should be sown on an area 15 by 15 feet, or four bushels to the acre. Qt. 45 cts., 4 qts. $\$ 1.50,8$ qts. $\$ 2.75,1 / 2$ bus. $\$ 4.75$, bus. $\$ 9,10$ bus. $\$ 85$. Charges prepaid when cash accompanies order. Weight, 22 pounds per bushel.

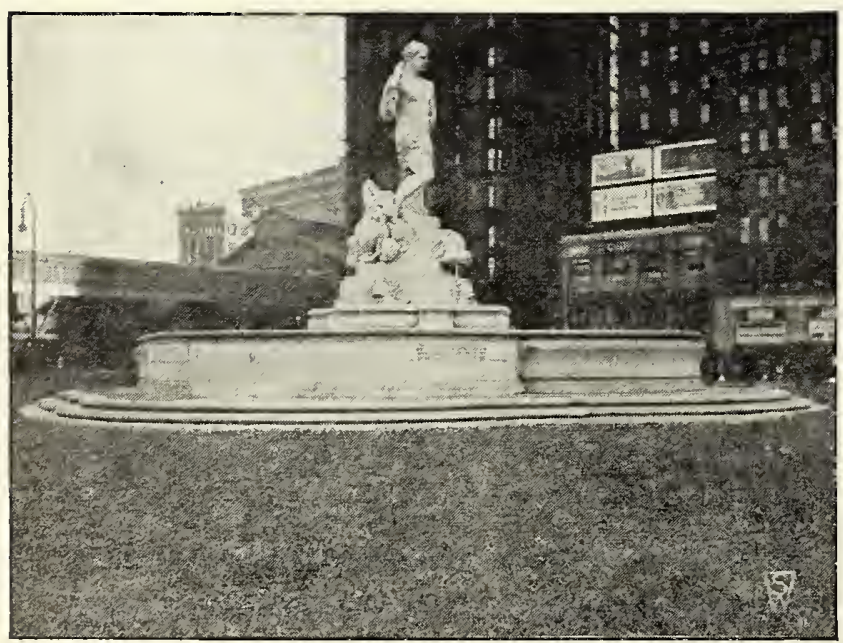

"Civic Virtue," the much-discussed statue in City Hall Park, New York City. A good turf resulted in a few weeks from seed sown around the base, fall, I922.

Stumpp \& Walter Co.'s High-Grade Lawn Seeds supplied to the New York Parks Department.

\section{TERRACE SOD LAWN SEED}

\section{FOR TERRACES, HILLSIDES AND EMBANKMENTS}

To Grass a Bank or Terrace. For each square rod take two quarts of lawn grass seed and mix it thoroughly with 6 cubic feet of good, dry garden loam. Place it in a tub, and add liquid manure, diluted with about two-thirds of water, so as to bring the whole to the consistency of mortar. The slope must be made perfectly smooth, and then well watered, after which the paste should be applied, and made as even and thin as possible.

A special mixture of grasses best suited for sowing on terraces and side-hills-grasses that produce strong, spreading roots, thus preventing heavy rains from washing them out, that will withstand drought and exposure, thrive on shallow soils, and at the same time produce a rich, green turf throughout the season. Qt. 60 cts., 4 qts. $\$ 1.90,8$ qts. $\$ 3.50,1 / 2$ bus. $\$ 6.25$, bus. $\$ 12$, 10 bus. \$115. Charges prepaid when cash accompanies order. Weight, 20 pounds per bushel.

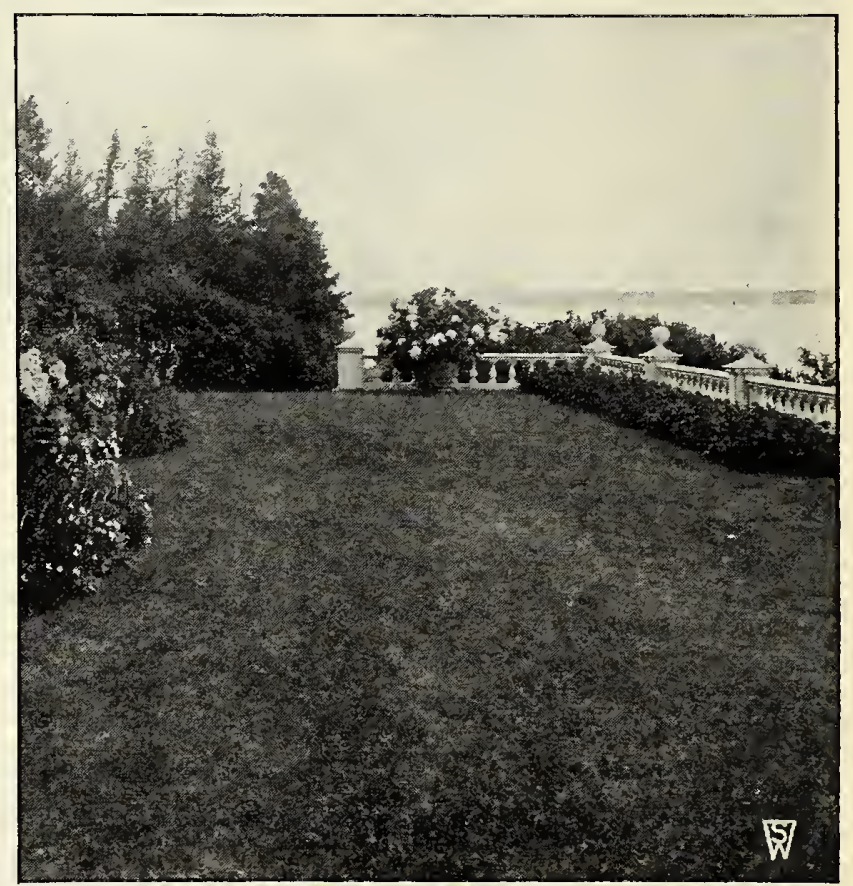

Stumpp \& Walter Co.'s Seashore Lawn Grass

\section{HIGH-GRADE LAWN SEED}

\section{FOR PARKS AND OTHER LARGE AREAS}

Our High-Grade Grass Seed is composed of fine, recleaned grasses, care being taken to include varieties of high purity and vitality. They are carefully proportioned so that they will succeed one another and give the lawn that much-desired green, velvety appearance through the summer. One quart will sow I 5 by. I 5 feet or four bushels to the acre; use one-half these quantities for renovating old lawns.

Our best grass seed mixture is "Staigreen," which will produce the finest possible turf. Our second quality mixture is "High Grade," and we advise its use on large areas or on lawns when low cost of materials is more important than extreme fineness of turf. Qt. 45 cts., 4 qts. $\$ 1.50,8$ qts. $\$ 2.75,1 / 2$ bus. \$4.75, bus. $\$ 9,10$ bus. $\$ 85$. Charges prepaid when cash accompanies order. Weight, 22 pounds per bushel.

\section{White Dutch Clover}

The best variety for lawns, as it forms a close herbage and remains green throughout the season. Lb. 65 cts., postpaid 75 cts.; 10 lbs. $\$ 6,100$ lbs. $\$ 55$. 

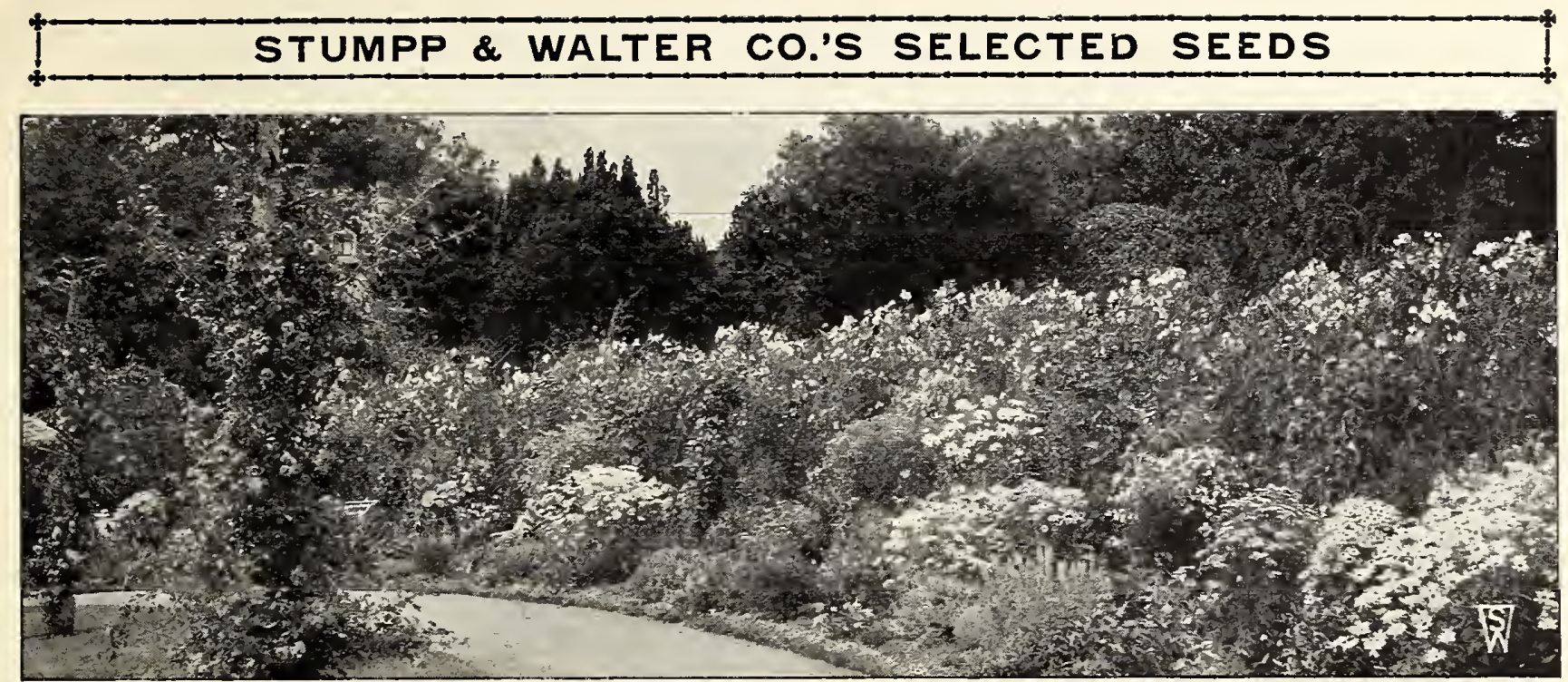

\section{ANNUAL FLOWER SEEDS \\ A list of Hardy Perennia!s will be found on page 42}

In presenting this list of Flower Seeds for your attention, every care has been taken to secure seeds from sources of supply known to us, and from our experiences and from our tests at our trial grounds, to be of the highest possible merit. Our Flower Seeds are selected with an idea of superiority of strain and we handle only the highest possible types in each respective class.

We mail all Flower Seeds FREE OF COST to any post office in the United States

\section{AGERATUM (Floss Flower)}

One of the very best bedding plants, being literally a sheet of bloom from early summer till frost. Easily raised from seed, which is usually started in a hotbed or window and transferred to the open ground in May.

Blue Perfection. Large heads of deep blue flowers produced in abundance. Fine for cutting. Pkt. Io cts., 1/40z. $50 \mathrm{cts}$.

Little Dorrit, Blue. This variety grows about 6 inches high; flowers bright blue. Pkt. Io cts., 1/40z. 50 cts.

Little Blue Star. A very dwarf variety used largely for edging, growing about 4 to 5 inches high; bright blue flowers. Pkt. $25 \mathrm{cts}$., 5 pkts. \$I.

\section{ALYSSUM}

This most popular hardy annual needs little introduction. Used extensively as a border for the flower-garden, but equally valuable as a cut-flower, owing to its delightful fragrance.

Little Gem ( $A$. maritimum). Plants grow only 3 to 4 inches high and each plant completely covers a circular space of 12 to 20 inches. Pkt. Io cts., oz. 75 cts.

Sweet Alyssum (A. Benthami). The well-known fragrant white variety. Pkt. Io cts., oz. $50 \mathrm{cts}$.

\section{ANTIRRHINUM (Snapdragon)}

This is considered one of the finest perennials which may be flowered from seed the first year. Plant-breeders in Europe and America vie with each other in introducing new strains each year. They are very valuable both as a cut-flower for home decoration or for bedding. We offer below six choice varieties of the Half-High type and six varie. ties of the Tall type. The Tall varieties are best seen to advantage in long borders in flower-gardens, making splendid subjects for backgrounds, while the Half-High type have now superseded the others in popularity on account of their suitability for bedding. Seed may be sown in the open ground early in May and be had in bloom in July, but it is best to start the plants indoors in pots or flats or in a frame in March and transplant the seedlings out-of-doors as soon as weather will permit.

\section{Giant-Flowered Tall Varieties}

\section{Height about 3 feet}

We offer a selection of the best six colors:

Garnet. Garnet.

Delicate. Rose-pink.

Queen Victoria. White.

Rose. Beautiful rose-pink.

Scarlet. Bright scarlet.

Yellow. Rich golden yellow.

NAMED VARIETIES, each, pkt. 15c., 1/40z. 75c.; Mixed, pkt. 10c., 1/40z. 60c. COLLECTION: One pkt, each of above 6 distinct colors, 75 cts.

\section{ARCTOTIS GRANDIS}

\section{African Daisy}

A remarkably handsome annual from southwestern Africa. It forms much-branched bushes 2 to 3 feet high; its flowers are large and showy, being pure white on the upper surface. There are few annual flowers grown in the garden more valuable for cut-flower work than the Arctotis. 1t is easily grown from seed, and may be started in hotbed, in the house or in the open ground, the seed germinating in about five days. The plants may be expected to come into bloom early in June and continue until quite hard frost. It delights in a sunny situation. As a cut-flower it is especially valuable, the blooms lasting a week or ten days in water, and if undeveloped buds are cut and placed in a sunny window. every one will open and produce as fine flowers as though left on the plant. Pkt. I5 cts., 1/40z. 75 cts.

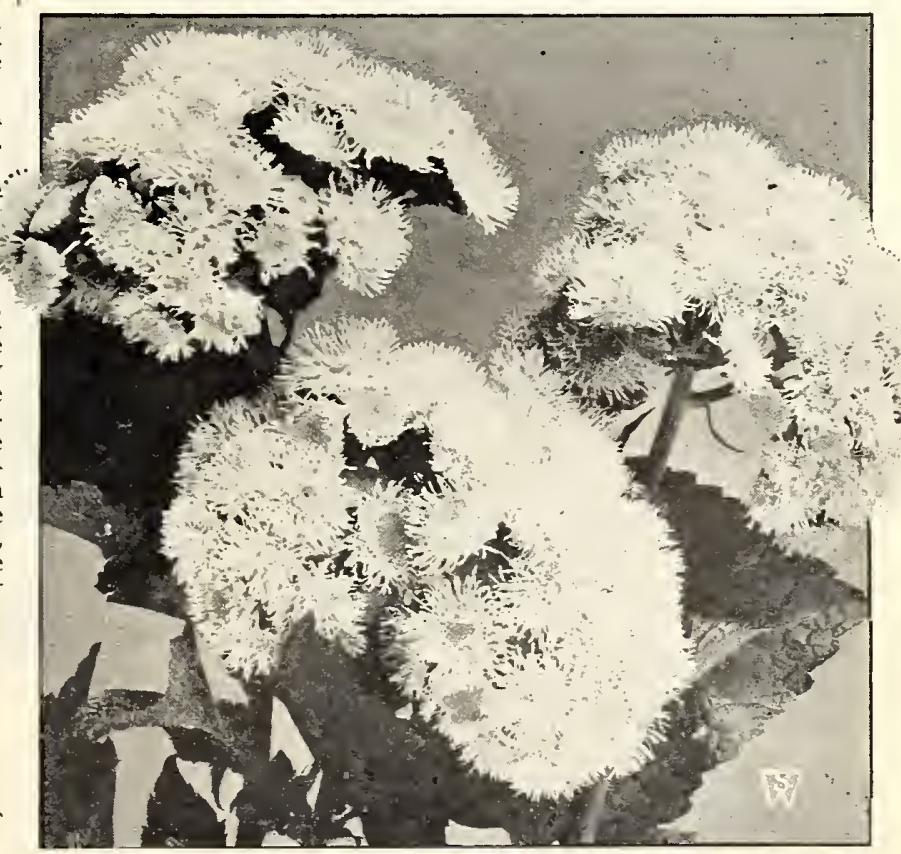

Ageratum 


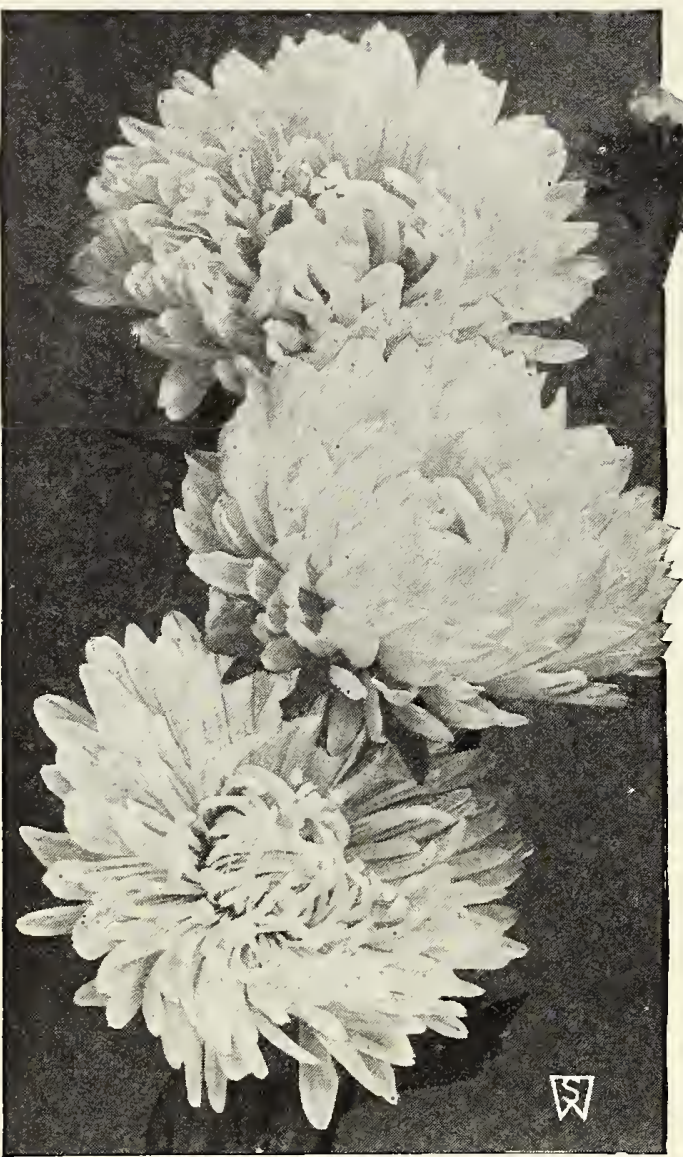

S. \& W. Co.'s Queen of the Market Strain Asters

\section{S.\&W.Co.'s Late Branching Asters}

This exceptionally fine Aster is without a rival. It is as well known in Europe as in America. The flowers are of extraordinary size and stand erect on long, graceful stems, well above the folíage; flower-stems I5 to 20 inches long. Grand for cutting. Plants extra large and of strong growth. Pure White Purple Lavender Mixed Rose-Pink
Any of the above colors, pkt. $10 \mathrm{cts} ., 1 / 40 \mathrm{oz} .50 \mathrm{cts}$. COLLECTION: One pkt. each of above 6 colors, $50 \mathrm{cts}$.

\section{Beauty}

This is a recently developed late-flowering strain, coming into bloom late in September and being at their best through October. The plants grow nearly 3 feet high and bear their very large, densely covered flowers on long, strong stems. Very desirable on account of their lateblooming character and excellence for cutting. $\begin{array}{lll}\text { Light Blue } & \text { Carmine-Rose } & \text { Purple } \\ \text { Light Pink } & \text { White } & \text { Mixed }\end{array}$

Any of the above colors or mixed, pkt. $15 \mathrm{cts} ., 1 / 4 \mathrm{oz} . \$ 1$ COLLECTION: One pkt. each of above 5 colors, $60 \mathrm{cts}$.

\section{Improved Crego or Ostrich- Feathered}

This is considered the finest of the Comet Asters. The flowers are large and fluffy, and their long stems make them excellent for cutting.

$\begin{array}{llll}\text { White } & \text { Purple } & \text { Lavender } & \text { Crimson } \\ \text { Azure-Blue } & \text { Pink } & \text { Deep Rose } & \text { Mixed }\end{array}$ Azure-Blue Pink Deep Rose Mixed COLLECTION: One pkt. each of above 7 distinct colors $75 \mathrm{cts}$.
S. \& W CO.'S
ASTERS

Asters will thrive in any good soil, prepared in the same way as you would for a crop of vegetables, but it is well to remember that any extra care taken in the preparation of the soil is repaid by finer plants, larger blooms, with longer stems and more profuse flowering. They should have an open, sunny position, and prefer a good, heavy, loamy soil enriched with a liberal quantity of Bone Dust No. 2, and an addition of air-slaked lime, and we do not advise growing them on the same ground two years in succession; it is better to change each season. For early flowering, seeds should be started in a sunny window, hotbed or coldframe in April and transferred to their place in the garden as soon as danger of frost has gone by. For August (midseason) and September (late) sow seeds outside in finely prepared ground in May, thinning out to I foot in the rows and 2 feet between. With the above prescribed treat ment and frequent cultivation of plants to insure a steady growth until flowering, excellent large blooms with long stems can be obtained.

White
$\begin{aligned} & \text { Qrimson } \\ & \text { Queen of the Market } \\ & \text { Fose } \\ & \text { Flesh-Pink }\end{aligned} \quad \begin{gathered}\text { Aight Blue } \\ \text { Dark Blue }\end{gathered}$
(EARLY)

Each, pkt. 10 cts., 1/40z. 50 cts.; 1 pkt. each of above 6 varieties, $50 \mathrm{cts}$.

\section{S. \& W. Co.'s Midseason Giants}

Since offering the Beauty type of Asters, we have frequently received inquiries for a Crego with the robust habit of growth and length of stems that characterize that class. Our grower, after several seasons of hybridizing and selecting, is now able to offer a type characterized by the Beauty's growth and the Crego or Ostrichfeather type of flowers-a true non-lateral Aster. The flowers are much larger and more substantial than the Improved Crego, measuring 5 to 6 inches in diameter and standing up well when shipped as cut-flowers. Their immense size and long, sturdy stems, make them very attractive as a cut-flower.

$\begin{array}{lll}\text { Peach Blossom } & \text { Deep Rose } & \text { Light Blue }\end{array}$

Añy of the above colors, each, pkt. 25 cts., $1 / 40 z . \$ 1.50$

COLLECTION: One pkt. each of above 6 colors, $\$ 1$

\section{King Asters}

A distinct type; plants are of strong, sturdy habit, fully I 8 inches high; the flowers are of large size and good substance, and with long narrow petals, which are more or less quilled, forming a very attractive flower.

$\begin{array}{lll}\text { Crimson King } & \text { Pink King } & \text { Violet King } \\ \text { Lavender King } & \text { Rose King } & \text { White King }\end{array}$

Mixed

Each, pkt. 15 cts., 1/40z. $\$ 1.25 ; 1$ p.kt. each of above 6 King Asters, 75 cts.

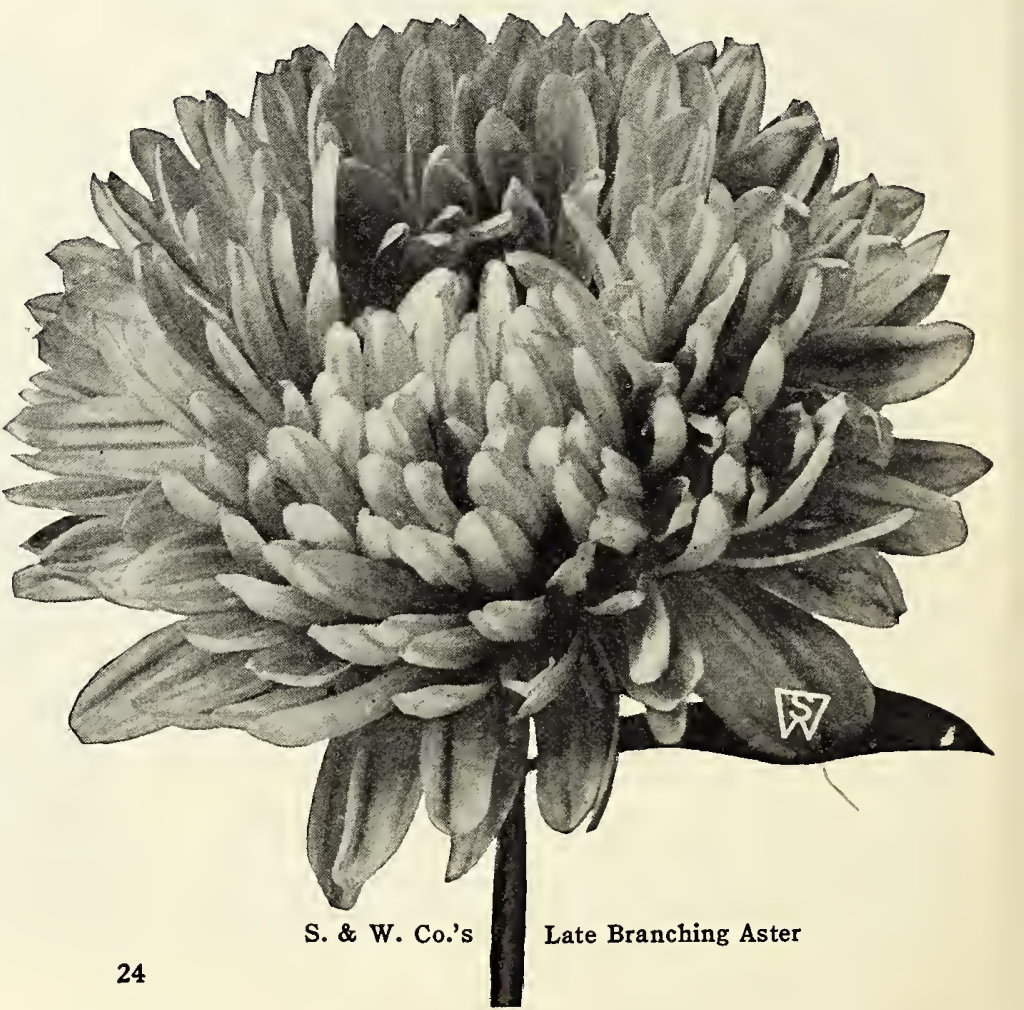




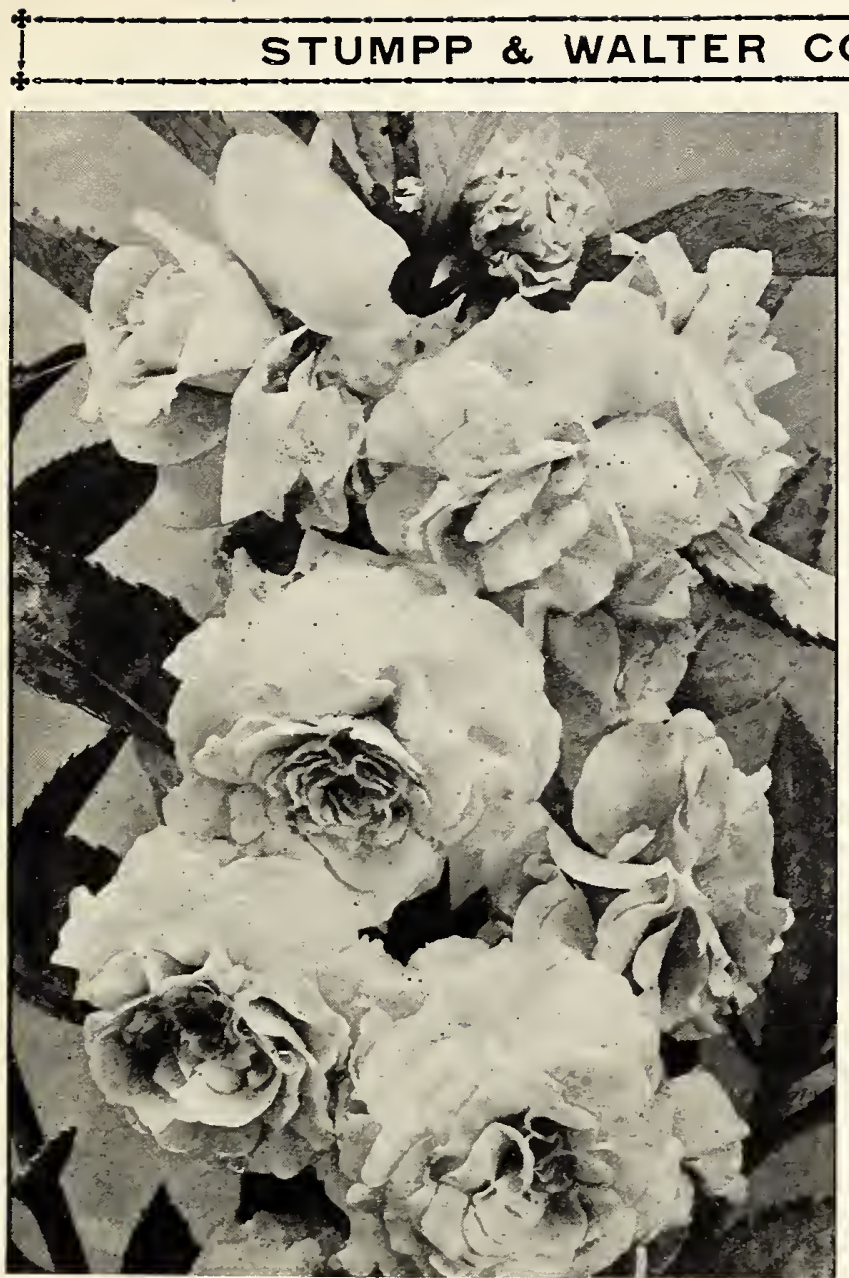

co.'s

SELECTED SEEDS

\section{DOUBLE CAMELLIA- FLOWERED BALSAM}

\section{Lady's Slipper}

An old and favorite garden flower, producing its gorgeous masses of beautiful, brilliant-colored, double flowers in the greatest profusion of easiest culture; succeeds in a good, rich soil. Tender annuals. 2 feet. Start the seed indoors in April, or sow out-of-doors in May. When specimens are wanted, plant at least I 8 inches apart; splendid when grown in pots.

S. \& W. Co.'s Double Mixed. A mixture of selected self-colors as well as beautiful, spotted, blotched and striped varieties. Pkt. Io cts., oz. \$I.5O.

\section{BRACHY COME $\underset{\substack{\text { Swan River } \\ \text { Daisy }}}{\text { B }}$}

Free-flowering, dwarf-growing annuals, covered during the greater part of the summer with a profusion of pretty blue or white flowers, suitable for edgings, small beds or pot culture. Height, 9 inches. Blue Star Red Star White Star

Each, pkt. 15 cts., $1 / 40 z .75$ cts.

\section{CALLIOPSIS}

Showy and beautiful, free-flowering annuals and perennials, of the easiest culture, doing well in any sunny position, blooming all summer, and excellent for cutting and massing. It is best to sow them where they are to bloom; thin out to stand 6 inches to I 2 inches apart. By keeping the old flowers cut off, the flowering season can be lengthened until late autumn.

\section{Annual \\ Varieties}

Golden Wave.

Rich golden yel-

low, chestnut-

brown center.

Height I foot.

Choice Mixed.

Each, pkt. 10 cts.,

$1 / 4$ oz. $50 \mathrm{cts}$., oz.

Double Camellia-Flowered Balsam

$\$ 1.50$.

\section{CALENDULA (Pot Marigold)}

This is one of the best and showiest, free-flowering, hardy annuals, growing in any good garden soil, and producing a fine effect in beds or mixed borders.

Golden King. Rich golden yellow................... Pkt. $1 / 40 z$.

Lemon King. Rich lemon-yellow.

Orange King. Deepest orange.

Choice Double Mixed.

$\begin{array}{rr}\text { So } 25 & \$ 050 \\ 25 & 50 \\ 25 & 50\end{array}$

\section{CARNATIONS}

Carnations are general favorites for their delicious fragrance and richness of colors. They are indispensable, both for greenhouse culture in winter and for the garden in summer. The Marguerite type is one of the best for summer flowering.

\section{Giant Marguerite Carnations}

These are deservedly the most popular Carnations with the amateur, as they begin flowering in July or August if sown early in the spring. The strain offered is of extra-fine quality, producing on long, strong stems an abundance of large, double, beautifully fringed, highly scented flowers; with slight protection they will survive an ordinary winter and bloom freely the following spring.

\section{Giant Pink \\ Giant Crimson \\ Giant Scarlet Giant White \\ Each, pkt. 15 cts., 1/40z. $\$ 1$, oz. $\$ 3$ \\ COLLECTION: One pkt. each of above 5 colors, 50 cts. \\ CARDINAL CLIMBER \\ Ipomoea Quamoclit hybrida}

Giant Yellow Giant Mixed

A rapid grower, often attaining the height of 30 feet or more. The deeply laciniated, fern-like foliage and fiery cardinal-red flowers are borne in profusion from July to frost. The flowers are about $1 / 2$ inches in diameter and are borne in clusters of five to seven blooms. Seed may be sown indoors during April, or outdoors in May. Soaking seeds in warm water before planting hastens germination. Pkt. I 5 cts., 2 pkts. 25 cts.

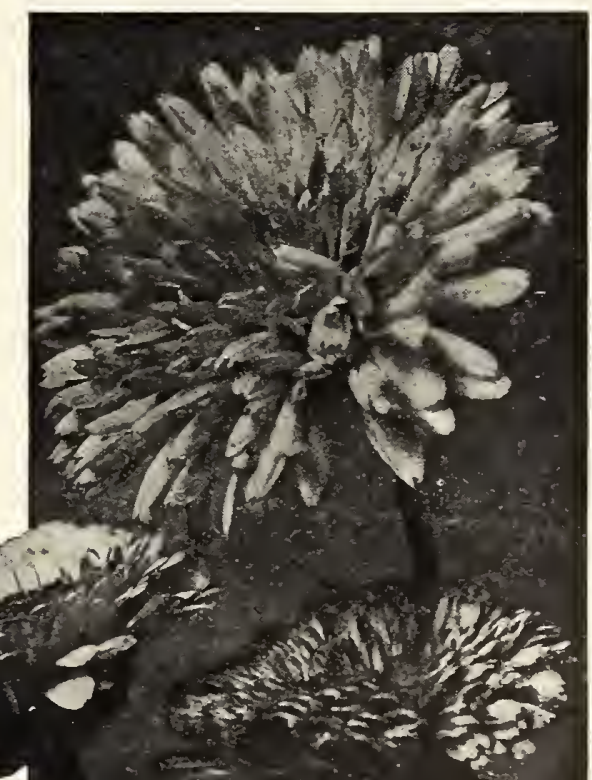




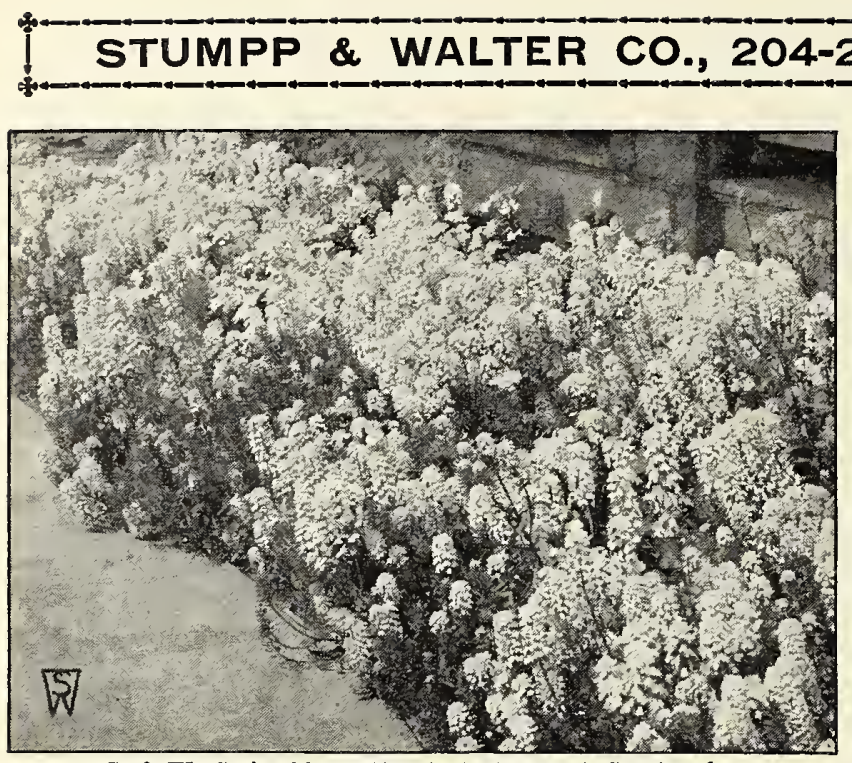

S. \& W. Co.'s Giant Hyacinth-flowered Candytuft

\section{CELOSIAS}

\section{Celosia cristata (Cockscomb)}

Free-blooming annuals, growing best in rather light soil, not too rich; make grand border plants and are attractive for pots. Seed can be sown under cover in early spring and planted out in May, or may be sown outdoors in May. If dwarf growth is desired, do not crowd.

Empress. Rich crimson. I foot. Pkt. I5 cts., I/40z. $\$$ I.

Glasgow Prize. Dark crimson. I foot. Pkt. I5 cts., I/40z. $\$ \mathrm{I}$.

Dwarf Mixed. I foot. Pkt. Io cts., $1 / 40 z .75$ cts.

\section{Celosia plumosa (Feathered Cockscomb)}

Make fine plants for large beds or groups, and the plumes or flowers can be cut and dried for winter bouquets. Should be treated same as Cockscomb described above.

Ostrich-plumed, Crimson. Pkt. Io cts., 1/40z. $50 \mathrm{cts}$.

Ostrich-plumed, Yellow. Pkt. I o cts., $1 / 402.50 \mathrm{cts}$.

Ostrich-plumed, Mixed. Pkt. Io cts., $1 / 40 z$. $50 \mathrm{cts}$.

\section{Chinese Woolflower (Celosia Childsi)}

This is a unique form of the feathered Cockscomb, growing 2 to 3 feet high and about the same size in diameter. Each branch is terminated with a large head of rich crimson flowers that look as if made out of some silky wool material. A very effective annual for beds and borders. May be used to excellent advantage as a cut-flower as well.

We offer in two separate colors, namely: Crimson and Pink. Each, per pkt. I 5 cts., 2 pkts. 25 cts., $1 / 4 \mathrm{Oz}$. \$I.

\section{COLEUS}

Tender perennial. Showy bedding plants which are grown for their brilliant foliage. The leaves range from light to dark red in color and are very finely marbled and spotted. Used extensively in ribbon beds and as foliage plants. Choice mixed. Pkt. $25 \mathrm{cts}$.

\section{GONVOLVULUS Morning-Glory}

Dwarf Bedding Varieties. Mixed. Pkt. Io cts., oz. $30 \mathrm{cts}$. Tall or Climbing Varieties. Mixed. Pkt. Io cts., oz. 30 cts.

Mixed Imperial Japanese (Emperor Morning-Glory). These are beyond question the handsomest of all Morning-Glories. Pkt. Io cts., oz. 5o cts.

\section{GLARKIA ELEGANS}

A mighty handsome annual, which should be far more widely known. It is of easy cultivation, graceful in habit of growth, and lends itself as well to bedding as for cutting. Pkt. Io cts., $1 / 40 z .25 \mathrm{cts}$.

\section{CANDYTUFT (Iberis)}

The Candytuft is almost as fragrant as the sweet alyssum and very popular. Very useful as a bedding plant or for border work. Sow outdoors in April, where it is to bloom, and thin well when the plants grow about I inch. Sow also in July for fall blooming. Where grown in rows, best results for cut-flowers can be obtained only by giving the plants at least a foot apart in the rows and I $I / 2$ feet between the rows.

S. \& W. Co.'s Giant Hyacinth-flowered. We con- Pkt. Oz.

sider this the finest white variety, which, through

selection, has been greatly improved. The flowers are

of large size, borne in large trusses well above the

foliage. Finest for cutting or for the border........ \$o I5 $\$ 2$ oo

S. \& W. Co.'s Mammoth-flowered Candytuft. Hardy Annuals. Large-flowered but uniformly dwarf types, suitable for edging, bedding, and for growth in the annual border.

Carmine Rose-Cardinal Lavender Crimson Flesh-Pink White. Each, pkt. 15 cts., $1 / 40 z .50$ cts., oz. $\$ 1.50$

COLLECTION: One pkt. each of above 6 colors, $75 \mathrm{cts}$.

Mixed Mammoth. Pkt. Io cts., 1/40z. $30 \mathrm{cts.,}$ oz. $\$ \mathrm{I}$.

\section{CASTOR-OIL PLANT}

\section{Ricinus}

The Ricinus are tall, stately growing plants of tropical appearnnce; their luxuriant foliage renders them exceedingly ornamental. Halfhardy annuals.

Communis (Castor-Oil Plant). Green foliage. 6 feet....... \$o Io Duchess of Edinburgh. Dark red foliage. 6 feet......... Io Zanzibariensis. New Giant Castor-Oil Plant from Africa ... Io Mixed ........................... $\$ 2,0 z .25$ cts... I0

\section{GYPRESS VINE}

\section{Ipomvea Quamoclit}

One of the most popular of annual climbing plants with very delicate fernlike foliage, and masses of beautiful, small, star-shaped flowers. It is advisable to soak seed in water for a few hours before planting out in order to hasten the germination. Frequently attains a height of I 5 feet; sow outdoors in May. We offer it in three colors, also in a mixture.

Crimson White Pink Mixed

Each, pkt. 10 cts., 1/40z. 25 cts.

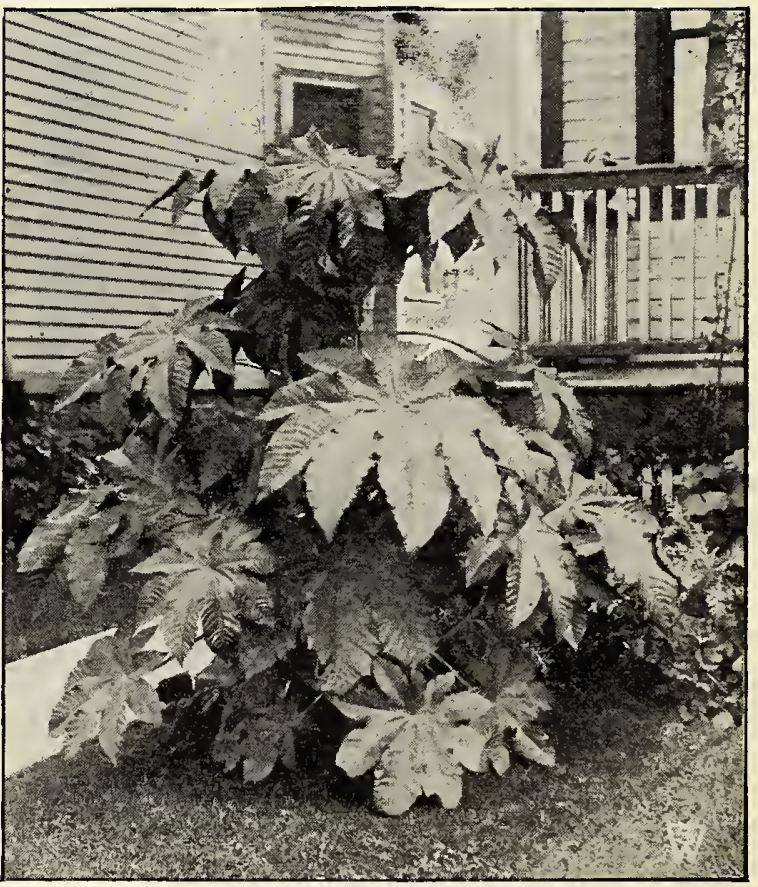

Castor-Oil Plant 


\section{GENTAUREAS}

There is, perhaps, no more popular annual than the Centaurea. Will grow well anywhere and as a cut-flower is much in demand.

\section{Double Cornflowers Centaurea Cyanus}

These are also known as Blue Bottle, Bachelor's Buttons, Ragged Sailor, Bluet, and sometimes referred to as Ragged Robin. As Ragged Robin is also a name given to Lychnis, we suggest patrons ordering by botanical name to avoid confusion. We offer a much improved strain of this beautiful flower in a better range of colors, with larger flowers. The seed may be sown outdoors in April, and several sowings will give a succession of bloom. For best results, thin out plants to stand 8 inches apart.
Blue
Rose-Pink
White
Maroon
Mauve
Rosy Red

Any of the above colors, pkt. $10 \mathrm{cts}, 1 / 402.30 \mathrm{cts}$., $02.75 \mathrm{cts}$. COLLECTION: One pkt. each of above 6 colors, $50 \mathrm{cts}$.

Double Mixed. A mixture of all the above colors. So Io $\begin{aligned} & \mathrm{T} / 40 z \\ & \text { So } 25\end{aligned}$

\section{Giant Sweet Sultans Centaurea imperialis}

This beautiful class is undoubtedly the finest of all the Sweet Sultans for cutting purposes. Beautiful, deliciously sweetscented flowers are borne on long, strong stems and are particularly striking, lasting several days after cutting. We recommend sowing in succession every two weeks from May until July, thereby giving a continuous bloom from summer to fall.

Imperialis, White. Large and exquisitely sweet-scented. Imperialis, Pink. Pink, with tinge in center. Imperialis, Red. New. Deep amaranth-red. Imperialis, Purple. Brilliant rosy purple. Imperialis, Lilac. Beautiful lilac.

Imperialis, Yellow (Suaveolens). Bright yellow.

Imperialis, Mixed. A select mixture of above colors.

Pkt. of any of the above, $15 \mathrm{cts}$., $1 / 40 \mathrm{z} .50 \mathrm{cts}$.

COLLECTION: One pkt. each of the 6 colors, $60 \mathrm{cts}$.

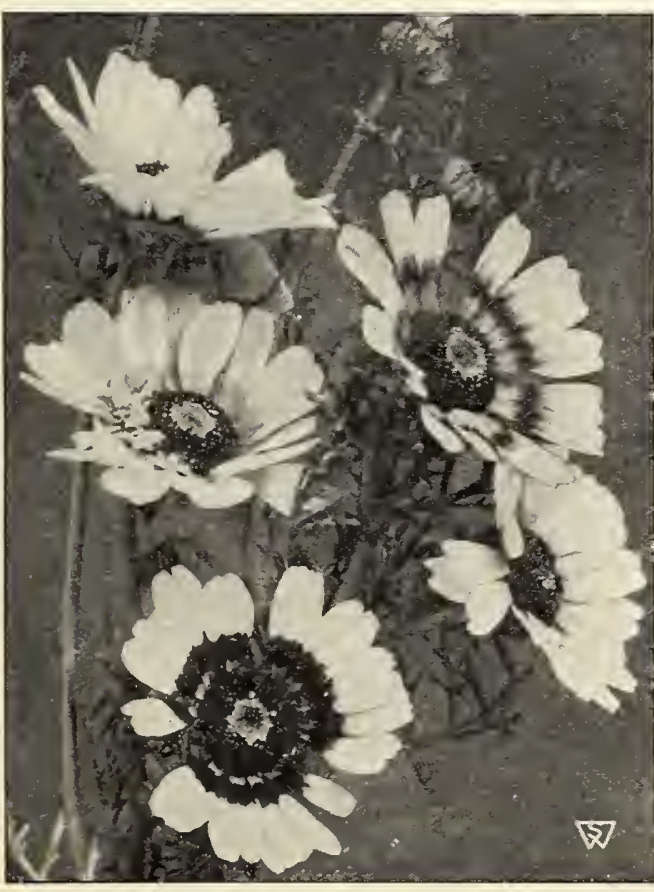

Annual Chrysanthemums

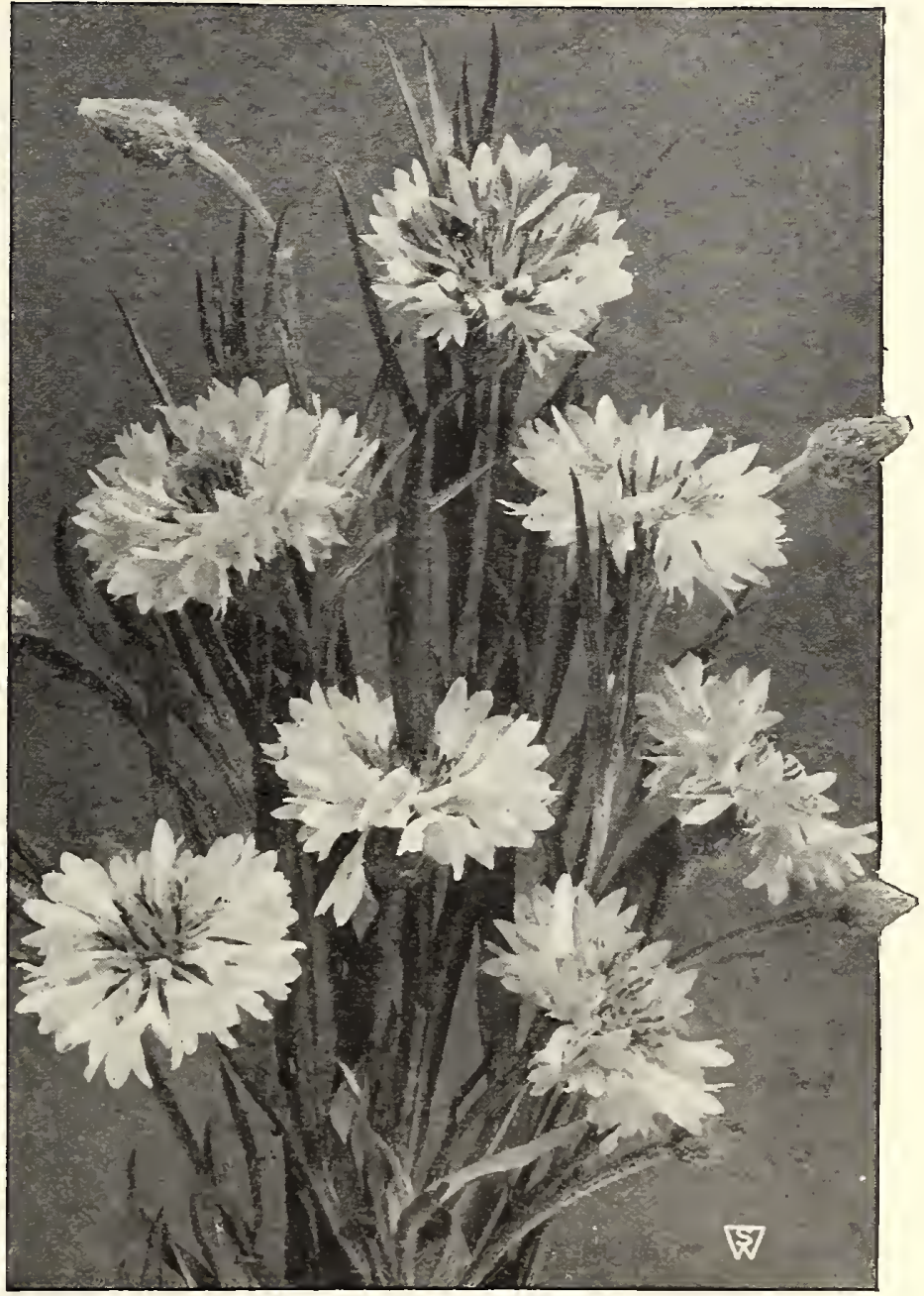

Centaurea Cyanus (Cornflower)

\section{GHRYSANTHEMUMS}

\section{ANNUAL VARIETIES}

We offer a choice selection of the best varieties of this showy hardy annual. They are splendid subjects for the border or for cutting. The plants average 2 feet in height, and bear their daisy-like flowers in great profusion on strong stems.

Burridgeanum. White, with a pink center....

Morning Star. Petals canary-yellow, with a halo of deeper yellow,

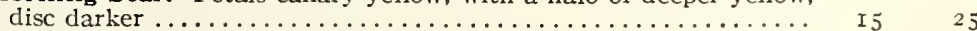

The Sultan. Rich wallflower-red with a narrow yellow zone around

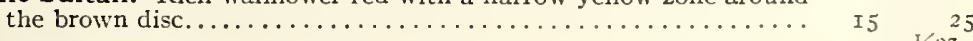

Golden Queen. Double; golden yellow................. I5 \$o 50

White Queen. Double; pure white................... I5 50

Single Annual Varieties Mixed. A choice mixture of Single-flowering varieties.

Double Annual Varieties Mixed. Mixture of double varieties....

\section{Cobæa (Cup-and-Saucer Vine)}

A climber of rapid growth, attaining a height of 30 to 50 feet during the season, valuable for covering trellises, arbors, trunks of trees, etc.; will cling to any rough surface. In sowing, place seeds edgewise and merely cover lightly with soil; to get early results, start the seed indoors in March or April; can also be sown outof-doors in May.

Scandens. Large bell-shaped purple flowers. Pkt. Io cts., 1/40z. 50 cts.

Scandens alba. Pure white. Pkt. I5 cts., $1 / 4 \mathrm{oz} .75$ cts. 


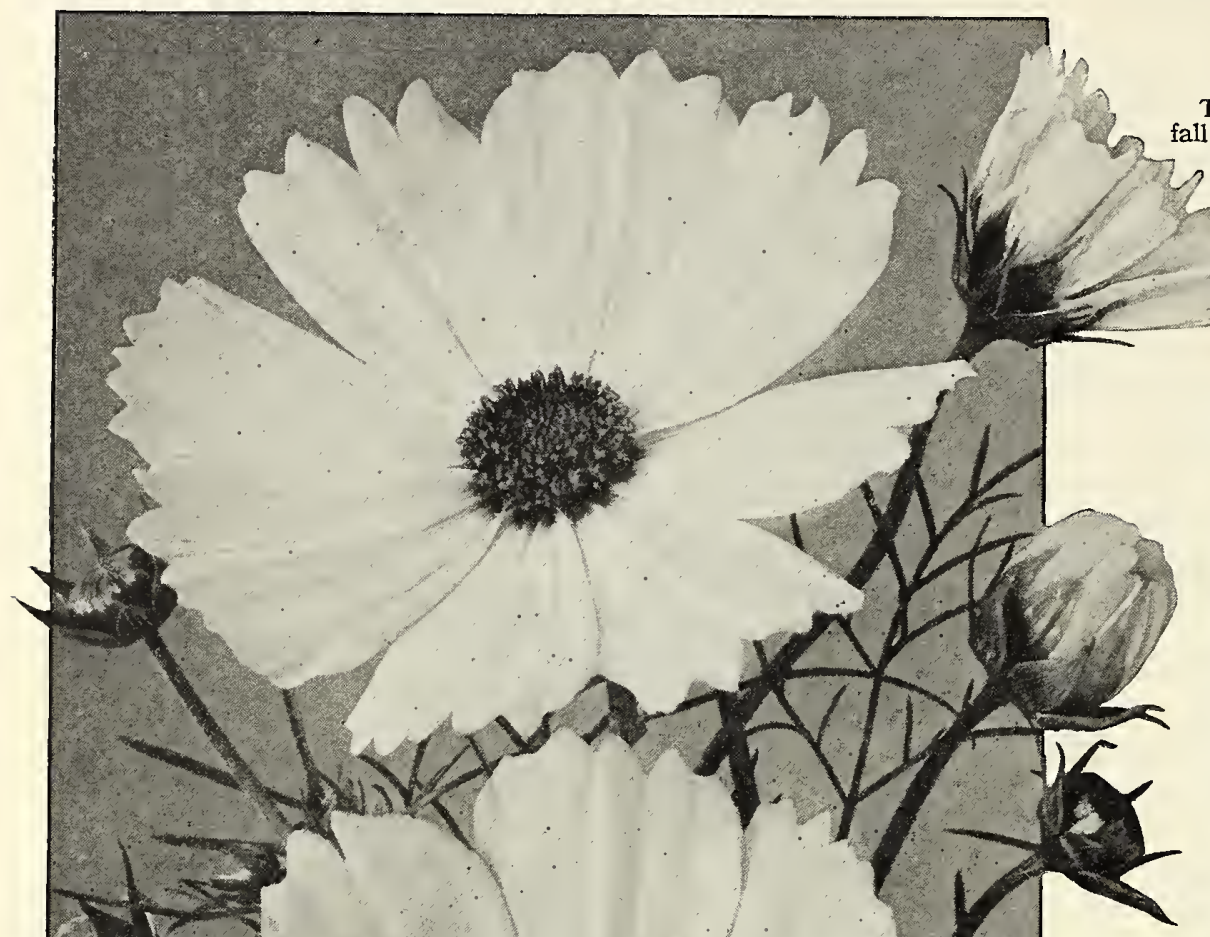

\section{COSMOS}

This is one of the most notable summer and fall flowers, the specialists' skill having added much to its beauty.

We recommend the sowing of Cosmos about the first of May, outdoors in rows, covering the seed about $1 / 4$ inch, and when the plants are about 3 inches high, thin out or transplant to not less than 2 feet apart. Any garden soil will grow Cosmos to perfection; frequent cultivation around the base of the plants will greatly benefit them.

\section{Early Single Dwarf Cosmos,} Summer-Flowering Type

Frequently the amateur finds that the Cosmos of the Late-flowering Tall type, selected by him for growing in borders or beds with other annual flowers, is unsuitable because of it flowering late in the summer, and also growing to the height of 6 to 8 feet. We, therefore, take pleasure in offering this new Early-flowering Dwart Cosmos, which, if sown outdoors about the first of May, will give an abundance of cutflowers for the table or home decoration from July until cut down by frost.

This type of Cosmos grows about 4 feet high, and while the flowers are not quite so large as the Late Mammoth-flowering type offered on this page, they are admirably adapted to the use of the suburbanite whose garden-space is small.
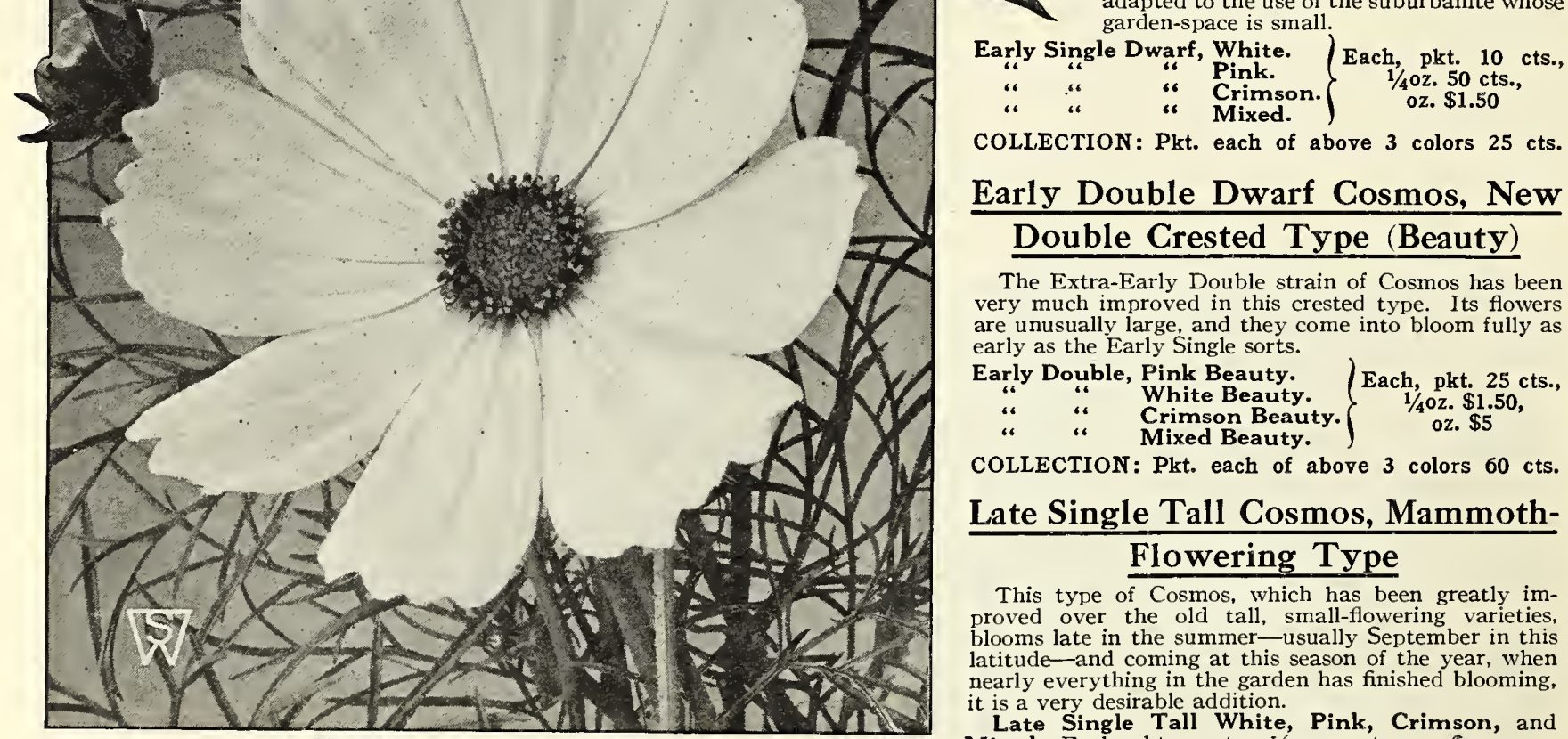

COLIECTION: Pkt. each of above 3 colors $25 \mathrm{cts}$.

Early Double Dwarf Cosmos, New

Double Grested Type (Beauty)

The Extra-Early Double strain of Cosmos has been very much improved in this crested type. Its flowers are unusually large, and they come into bloom fully as early as the Early Single sorts.

Early Double, Pink Beauty. TEach, pkt. $25 \mathrm{cts}$., “" “ White Beauty. $\quad 1 / 40 z . \$ 1.50$,

“ " $\quad \begin{aligned} & \text { Crimson Beauty. } \\ & \text { Mixed Beauty. }\end{aligned}$

COLLECTION: Pkt. each of above 3 colors $60 \mathrm{cts}$.

\section{Late Single Tall Cosmos, Mammoth- Flowering Type}

This type of Cosmos, which has been greatly improved over the old tall, small-flowering varieties, blooms late in the summer-usually September in this latitude-and coming at this season of the year, when nearly everything in the garden has finished blooming, it is a very desirable addition.

Late Single Tall White, Pink, Crimson, and Mixed. Each, pkt. Io cts., $1 / 4 \mathrm{Oz} .30 \mathrm{cts}$., oz. $\$ \mathrm{I}$.

COLLECTION: Pkt. each of above 3 colors 25 cts. Lady Lenox. This is the very latest development of this popular autumn flower, bearing gigantic flowers, the petals having a wide Lad overlapping character and of splendid substance; its beautiful, deep rosy pink color and splendid form make this Cosmos one of the most widely grown. Pkt. Io cts., $1 / 40 z$. $50 \mathrm{cts}$., oz. $\$ 1.50$.

Lady Lenox, White. Similar to above, but white. Pkt. Io cts., 1/40z. 50 cts., oz. \$1.50.

\section{Late Double Tall Cosmos, Crested Type}

Some years ago, when we first offered this splendid new form of Cosmos, which was of Australian origin, we considered it a notable addition to this beautiful family of easily grown annuals for cutting. We are pleased to announce, however, that due to the painstaking effort on the part of an American grower, this strain has been further improved upon, in size of flower, greater degree of doubleness, and general vigor of the plant. Late Double Tall, Pink. Beautiful rose-pink. White. Pure glistening white.

Each, pkt. 25 cts., $1 / 40 z .75$ cts., oz. $\$ 2.50$ Crimson. Rich rose-crimson.

COLLECTION: Pkt. each of above 3 colors $30 \mathrm{cts}$. 


\section{STUMPP \& WALTER CO.'S SELECTED SEEDS}

\section{DIANTHUS (Pinks)}

In this large and greatly varied genus are some of our most beautiful and best-loved flowers, unsurpassed for color and fragrance. They are hardy biennials that bloom finely the first season, remaining green all winter and blooming the next year also, if lightly protected. Old plants flower the earliest, but as young ones give the largest, finest flowers, sowings are made every year. Seed may be sown in the open in early spring when the danger of frost is past and if the situation is open and the ground is well prepared, they will flower luxuriantly in a few weeks' time and continue until hard frost. For best results seedlings should be thinned out to have plants stand 6 inches apart. They average $I$ foot in height and are splendid for borders and for cutting. The double-flowering varieties are quite as fine as carnations for cutting.

\section{Double Annual Varieties}

Chinensis fl.-pl. (China, or Indian Pink). Flowers Pkt. are borne in clusters, very double and in a large range of bright colors...

Heddewigii fl.-pl. (Double Japan Pink). Double mixed, colors varying from richest crimson to most

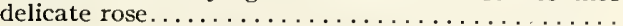

Fireball. New. Extra double brilliant dark scarlet, very beautiful. .

Laciniatus f.-pl. (Double Fringed Pink). Large double flowers with fringed edges. Various colors.

Salmon King. Brilliant salmon-rose. .

Snowball. Large; double; white; excellent for border

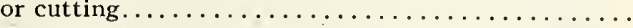

Violet Queen. A rich violet-rather unusual shade...

So Io \$o 50

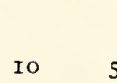

I5 75

I5 75

$15 \quad 75$

I5 50

I5 75

S. \& W. Co.'s Special Mixture of Annual Sorts. A grand collection of these ever-popular garden, or China Pinks. All largeflowering varieties, unrivaled for brilliancy and rich variety of color, and bloom in perfect succession during the whole summer and autumn in such numbers as fairly to crowd each other for room. Mixed colors. Pkt. ro cts., 1/40z. $50 \mathrm{cts}$.

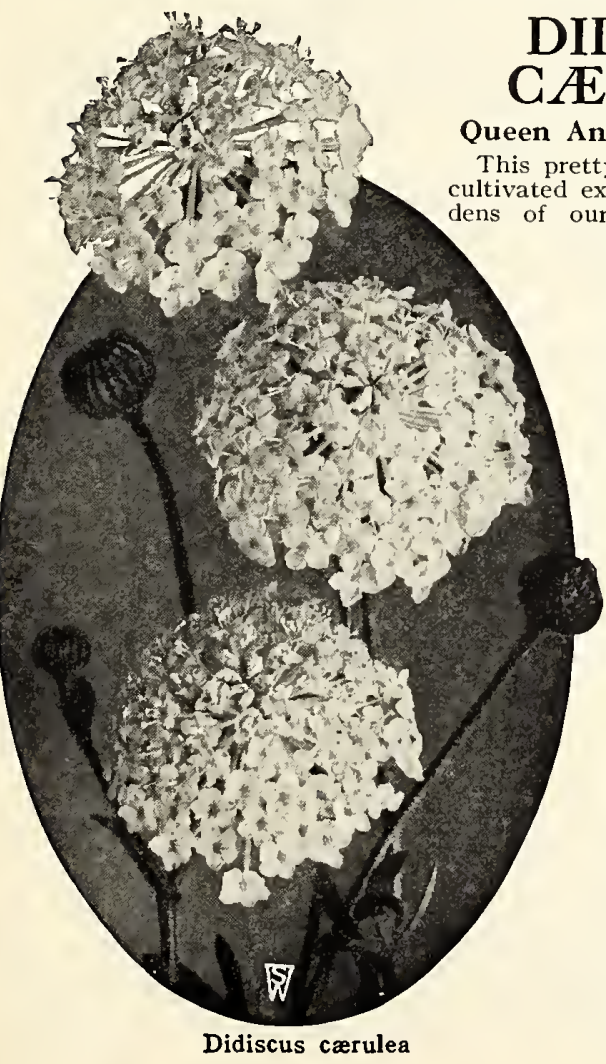

\section{ISGUS}

Queen Anne's Lace Flower

This pretty annual, which was cultivated extensively in the gargrandparents, has
been brought to prom

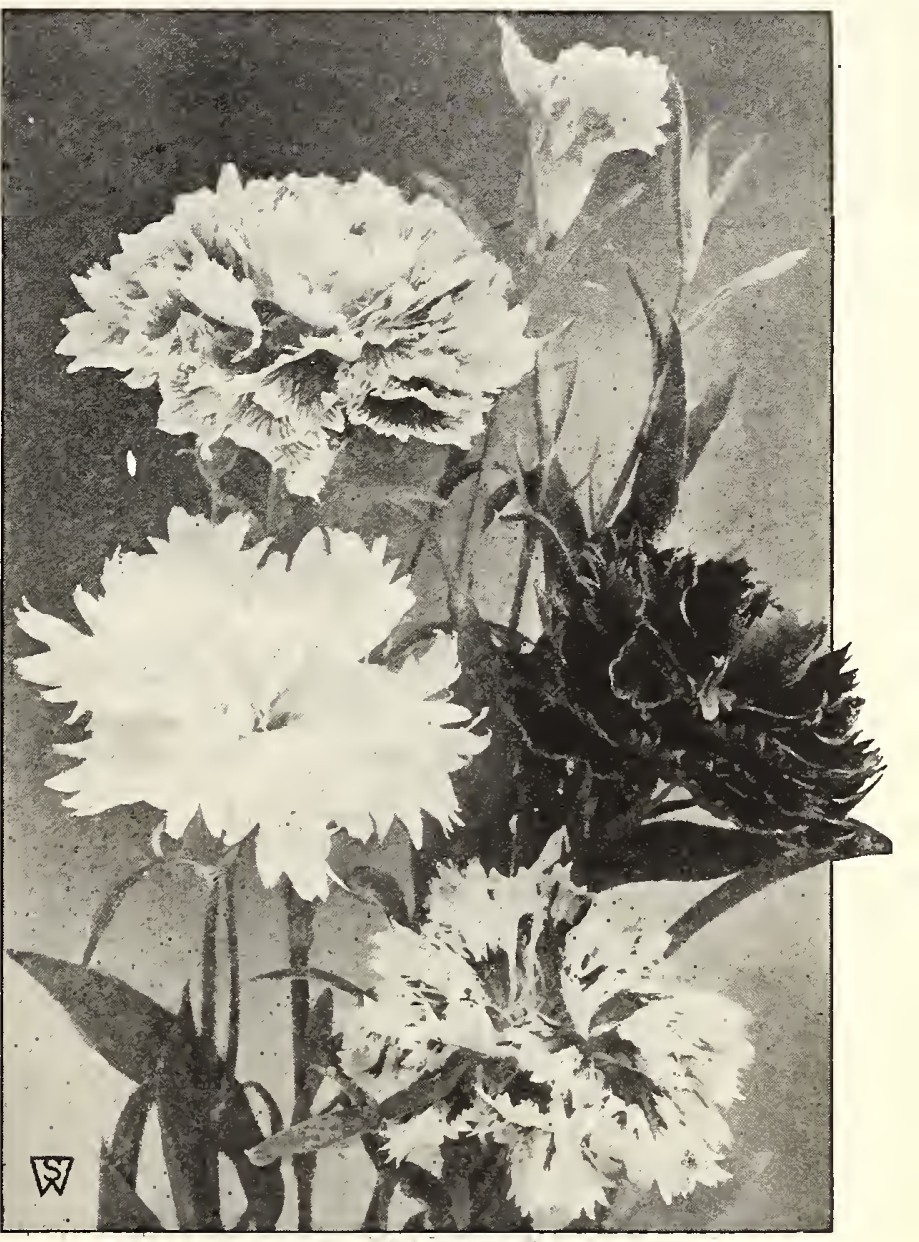

Double Annual Pinks (ho country now display appearance and color makc an instant apfeal. Few flowers are as plant about 2 feet high. Each branch ends in an umbel of sky-blue fowers which spread out in an umbrella-like fashion, crowning each shoot with a beautiful and delicate head of flowers. Each individual bloom in the umbel is carried on a thin and long tube, giving the flower-heads a distinct and refined appearance. The name Queen Anne's Lace Flower is most appropriately applied to the flowers, since the graceful form of the umbels of bloom resemble in their quaint and artistic arrangement the most delicate and dainty lace. It is easily grown and a splendid cut-flower, lasting unusually long in water. Seed may be sown outdoors in a well-prepared seed-bed when trees are out in leaf; water copiously during hot weather. Pkt. $25 \mathrm{cts} ., 1 / 4 \mathrm{Oz}$. $\$$.

\section{DIMORPHOTHECA (African Golden Daisy)}

An easily cultivated annual that will give a magnificent display all the summer.

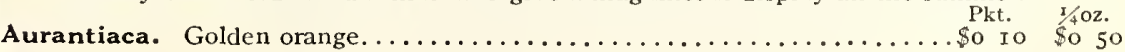

\section{DOLICHOS (Hyacinth Bean)}

A rapid-growing annual climber, flowering freely in erect racemes, followed by ornamental seed-pods. Fine for covering arbors, trellises, etc. Sow the seed in the garden in beds where it is to remain. Height ro feet.

Daylight. This grand Hyacinth Bean comes from Japan. In our trial-grounds, Pkt. $\mathrm{O}$.

plants from seed sown late in May had, by the middle of July, attained a height of over Io feet, and were covercd with spikes of snow-iwhite, pea-shaped blossoms from then until late fall. The heart-shaped foliage is bright green

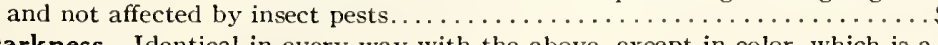

Darkness. Identical in every way with the above, except in

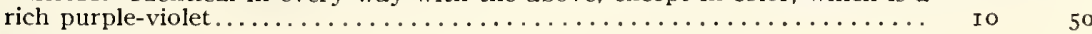
Lablab, Mixed....................................... Io 


\section{ESGHSCHOLTZIA (California Poppy)}

Profuse-blooming annuals, for beds, edging or masses. Bloom from early summer to frost. We offer below a choice list of what we consider the finest varieties in commerce.

Golden West. Bright yellow, dark orange at the base of the Pkt. $1 / 40 z$. petais........................................ 10 \$o 5o

Lovely. A lovely tone of bright rose-pink suffused with salmon. The blooms have a satiny appearance which adds very much to the effect ..............................................

Vesuvius. Rich coppery red which glistens in the sunlight...
S. \& W. Co.'s Choice Mixture. We have prepared a mixture of named sorts covering all the beautiful colors in this

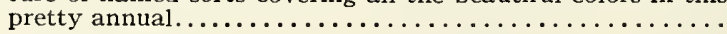

\section{EUPHORBIA}

Strong-growing annuals, suitable for beds of tall-growing plants or mixed borders. The flowers are inconspicuous; the foliage, however, is exceedingly ornamental. Variegata (Snow-on-the-Mountain). Attractive foliage, veined and margined with white. 2 feet. Pkt. Io cts., $1 / 40 z .25$ cts.

\section{FOUR O'CLOCK}

\section{Mirabilis}

Well-known, free-flowering plants. Called Four o'Clock because they open their blossoms at that hour in the afternoon; also called IMarvel of Peru. Hardy annuals. 2 feet.

Fine Mixed. All colors. Pkt. Io cts., oz. 5o cts.

\section{GAILLARDIA (Blanket Flower)}

\section{ANNUAL VARIETIES}

Very showy annuals of easy culture. The flowers are borne freely and are brilliant in tone. Excellent for borders and do best if sown in May. Flower in great profusion from July to November.

Amblyodon. Rich blood-red, 2 feet .................... \$o Io \$o 50

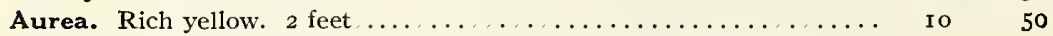

Picta Lorenziana. A mixture of various colors. The flowers are double

and excellent in form.

\section{GODETIA}

This beautiful hardy annual deserves more extensive cultivation. The plants bloom profusely and are splendid for bedding. We also recommend that those with greenhouse facilities try growing these as a pot-plant for winter decoration. We offer the single-flowering sorts, which grow about I foot high, and the double varieties, which attain the height of 2 feet.

Choice Double Mixed. Pkt. 25 cts.

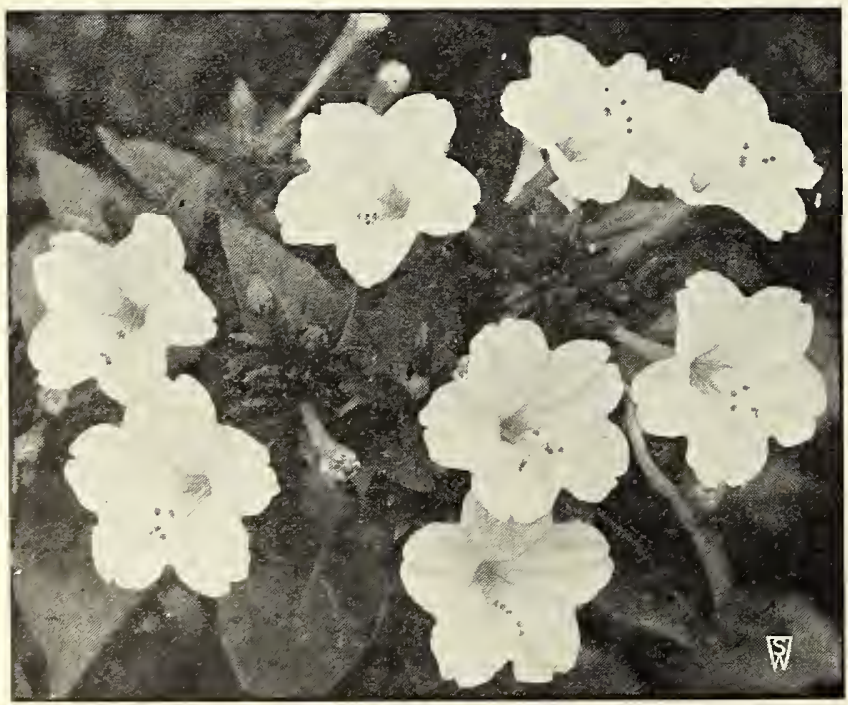

Four o'Clocks

\section{GLOBE AMARANTH}

\section{Gomphrena}

Popularly known as "Bachelor's Button." A first-rate bedding plant. The flowers resemble clover heads and can be dried and used in winter bouquets. Cornflowers and a number of other flowers are also known as Bachelor's Buttons, and in ordering it is well to order by name to prevent errors. We offer them in separate colors and in a mixture as well.

White Rose Purple Mixed

Each, pkt. 10 cts., oz. 75 cts.

\section{GYPSOPHILA}

\section{Baby's Breath}

Pretty, free-flowering, elegant plants, succeeding in any garden soil. Their misty white panicles of bloom are largely used for mixing with other cut-flowers.

Elegans grandiflora alba. This is an improved, large- Pkt. Oz.

flowering, pure white form of the annual Baby's

Breath; of free, easy growth. Several sowings should

be made during the season to keep up a supply..... \$o Io so 50

Elegans grandiflora rosea. Delicate rose........ Io 50 


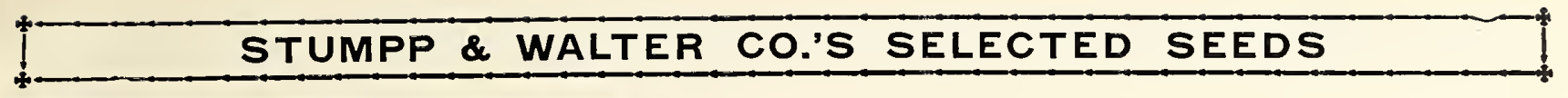

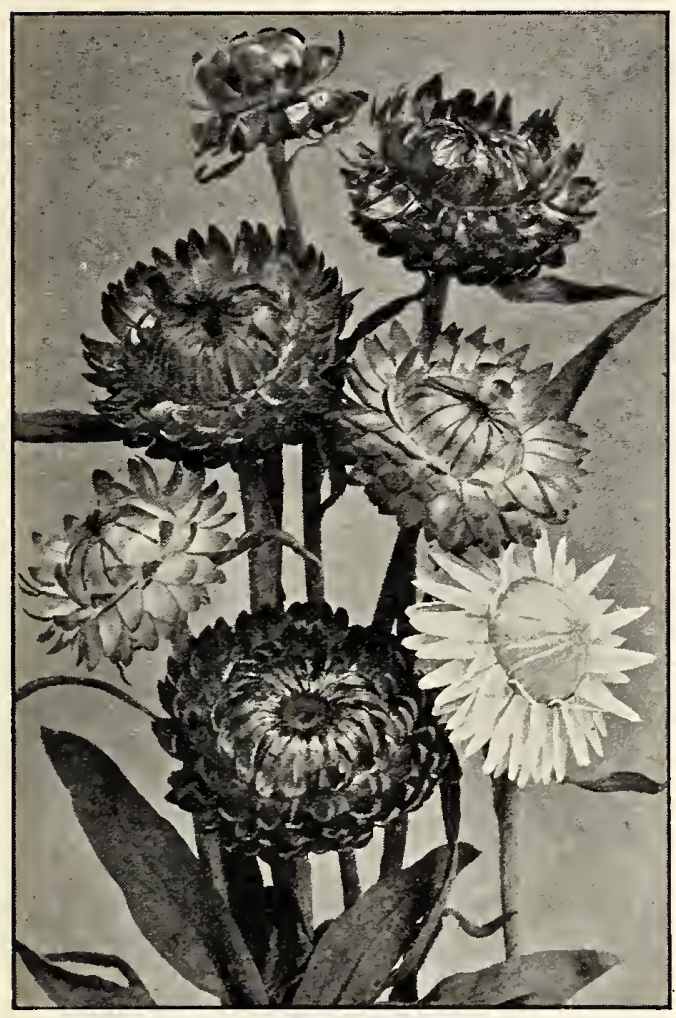

Helichrysums

\section{HELIANTHUS}

Sunflower

Much-prized annuals and perennials for cutting; the tall sorts are largely used in the perennial border; the dwarf sorts make good edgings to the tall.

\section{Annual Sunflowers}

The annual sorts of Sunflowers are indispensable for cutting. Sown in a sunny location in April or early May, they come to bloom early in the summer and flower continuously until cut down by frost.

Cut-and-Come-Again, Mixed. A mixture of the tall- Pkt. $1 / 40 z$. growing, large-flowering types for cutting.......... So Io So 50

Cucumerifolius (Miniature Sunflower). Small, single, rich yellow flowers; an abundant bloomer. 4 feet...

Globosus fistulosus (Globe or Dahlia Sunflower). Flowers large, double and of a rich saffron. 6 feet....

Gigantic Russian. The large-flowering Russian variety. Oz. Io cts., I/ $/ 4 \mathrm{lb} .25 \mathrm{cts} ., 1 / 2 \mathrm{lb} .40 \mathrm{cts} ., 1 \mathrm{~b} .75 \mathrm{cts}$.

\section{HELIOTROPE}

A half-hardy perennial, flowering during the whole season. Its delightful perfume makes it a most desirable bouquet flower. A splendid bedding plant, or can be trained as a greenhouse climber. Seed started indoors in the spring will make fine plants for summer blooming. Can also be sown outdoors in May.

Queen Marguerite. Large; dark blue.............. \$o I5 \$I 50

\section{HUMULUS}

\section{Japan Hop}

A rapid summer climber which attains a height of 20 to 30 feet, resembling the common Hop, but, being an annual, attains full perfection the first season. The foliage is luxuriant, making a dense covering. It is one of the best plants for covering verandas, trellises, etc., producing grateful shade and being very ornamental. Heat, drought and insects do not trouble it. Pkt. 1/40z. 1/20z. Oz. Japonicus..................... \$o Io \$o 30 \$o 50 \$o 75

\section{HELICHRYSUM (Straw Flower)}

This is, undoubtedly, the most popular of the Everlasting Flowers. Their The newer and improved decorations. Plants grow readily from seed sown in the open ground when

\section{Other Everlasting Flowers of Interest Include:}

pe Amaranth. Described on

(Sea Laven-

ious colors. Pkt.

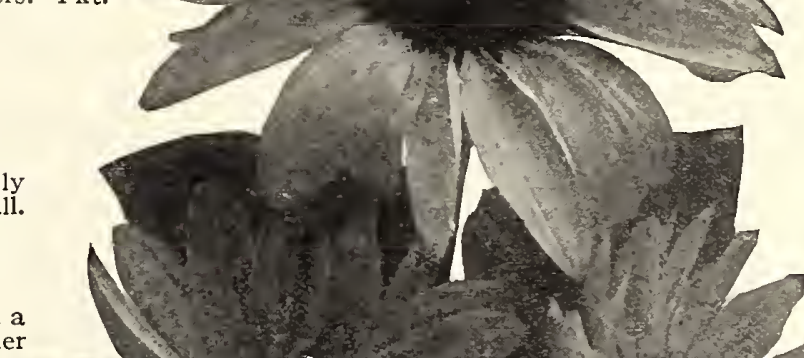

above 6 fine varieties, $50 \mathrm{cts} ., 1 / 4 \mathrm{oz}$. eacin of above 6 fine varieties, $\$ 2.50$

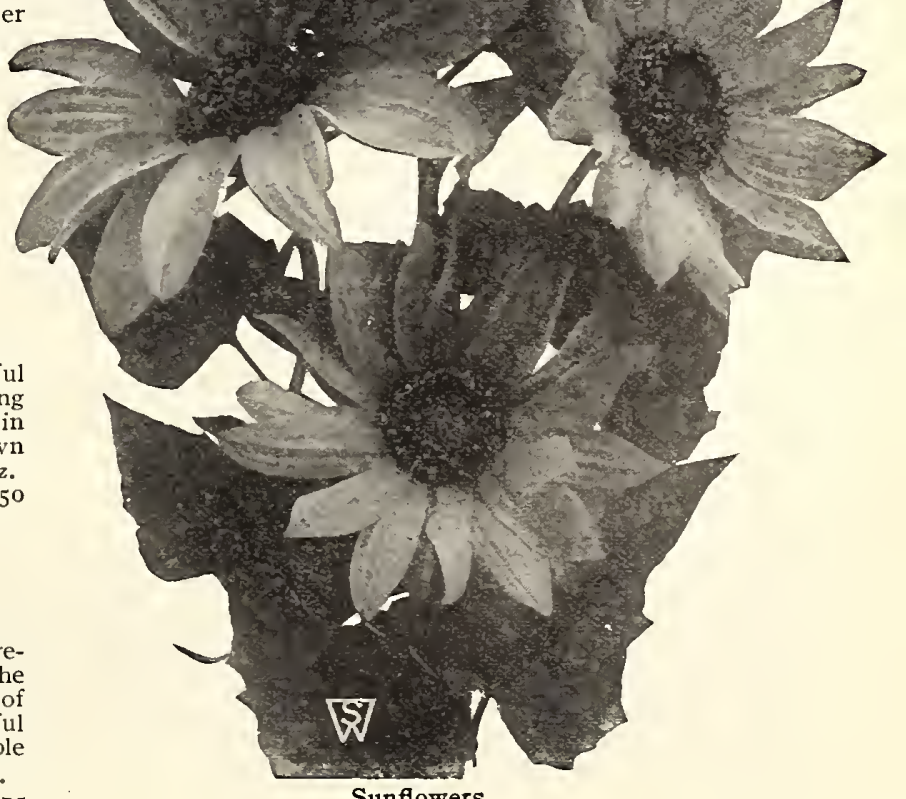

Sunflowers 
STUMPP \& WALTER CO., 204-206 N. EUTAW ST., BALTIMORE, MD.

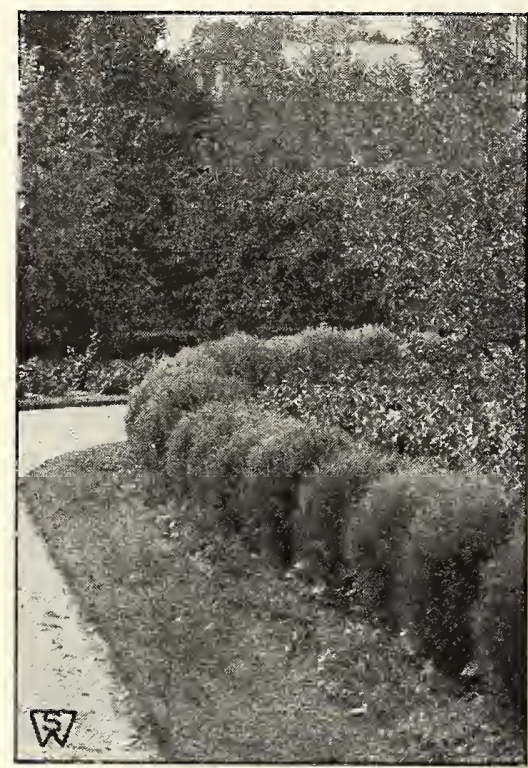

Kochia tricophylla

\section{HUNNEMANNIA}

\section{Giant Yellow Tulip Poppy; Bush Eschscholtzia}

Fumarizefolia. This is by far the best of the Poppy family for cutting, remaining in good condition for several days. Seed sown early in May will, by the middle of July, produce plants covered with their large, buttercup-yellow, poppy-like blossoms, and never out of flower until hard frost. The plants grow about 2 feet high, are quite bushy, with beautiful, feathery, glaucous foliage. Pkt. xo cts., $1 / 4 \mathrm{Oz} .50 \mathrm{cts}$., oz. $\$ \mathrm{I} .50$.

\section{IPOMOEA}

Climbers of rapid growth, with beautiful and varied flowers. For covering walls, trellises arbors, or stumps of trees they are invaiuable. It is well to soak the seed in warm water over night to assist in germination.

Bona-nox (Evening-Glory). Rosy lilac flowers, expanding in the evening; of very rapid growth. Pkt. Io cts., $0 z .75 \mathrm{cts}$.

Grandiflora mexicana alba (Moonflower). At night and during dull days the plants are covered with an abundance of large, pure white, fragrant flowers, 5 to 6 inches in diameter. It grows rapidly and wili cover a large surface. Pkt. Io cts., oz. $75 \mathrm{cts}$.

Rubra carulea (Heavenly Blue). Immense flowers of bright sky blue, very beautiful. Pkt. I5 cts., 2 pkts. $25 \mathrm{C}$

Mixed Imperial Japanese (Emperor Morning-Glory). The handsomest of all Morning-Glories, and of the easiest culture. Great variety of shades, and some of the flowers are spotted. marbled, and striped. Pkt. ro cts. oz. $50 \mathrm{cts}$.

KOCHIA (Summer Cypress; Mexican Firebush)

Trichophylla. A pretty haif-hardy annual, 2 to 3 feet in height, which grows into a perfect pyramidal-shaped cypress bush, with small, feathery, light green foliage, deepening as the season advances until it becomes a lovely crimson hue about September. Excellent for edging or hedging. Pkt. Io cts., 1/40z. $25 \mathrm{cts}$.

\section{ANNUAL LARKSPURS}

These are among the best-known garden flowers, and in recent years a vast improvement has been effected by careful selection in size and color of the blossoms and the general habit of the plant. Seeds sown in the open ground before the close of April will produce flowering plants by the beginning of July, and give a continuous succession of fowers from then until frost, a record that is not surpassed by any other annual. They make handsome beds or lines, and their free, graceful habit and bright colors are very effective when interspersed in the old-fashioned flower or shrubbery border. They stand well when cut, and a vase of one or mixed colors is indeed charming.

\section{Double Stock-Flowered}

This is the finest variety of this very popular annual, with beautiful double flowers. Height $2 \frac{1}{2}$ to 3 feet.

Snowstorm. Pure white. Stella. Sky-blue. Loveliness. Shell-pink. Attraction. Bright rose. King of the Blues. Dark blue. Tricolor. Variegated. Defiance. A decided improvement over the Newport Scarlet. This Larkspur is of the same habit as our Double Stock-flowered.

Each, pkt. 15 cts., $1 / 4 \mathrm{oz} .50$ cts., oz. $\$ 1.50$

Tall Stock-flowered, Mixed. A select mixture of our famous Stock-flowered strain. Pkt. Io cts., oz. $\$$ I.

Dwarf Stock-flowered, Mixed. Finest double flowers. Mixed. I $1 / 2$ to 2 feet. Pkt. Io cts., OZ. \$I.

\section{LANTANA}

One of the most desirable half-hardy greenhouse or bedding plants, which bloom constantly. The flowers are borne in verbena-like heads of orange, white, rose, etc Mixed colors, pkt. Io cts., $1 / 40 z$. $50 \mathrm{cts}$.

\section{LOBELIA}

These bloom very quickly from seed and flower all through the season. For beds, edgings, baskets, and pots there is nothing prettier. Sow outdoors in early spring, where the plants are to grow, and thin moderately; or transplant several inches apart in rich, open soil. Some stimulant given when they are in bloom greatly improves the flowers. Almost all are also good winter conservatory plants of trailing habit. The perennial or tall varieties are handsome, showy plants and will be found quite effective for backgrounds and grouping.

Crystal Palace Compacta. Rich deep blue; dark foliage. The finest Pkt. 1/4oz.

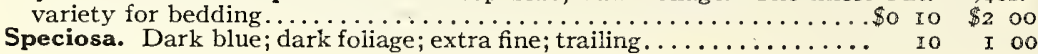

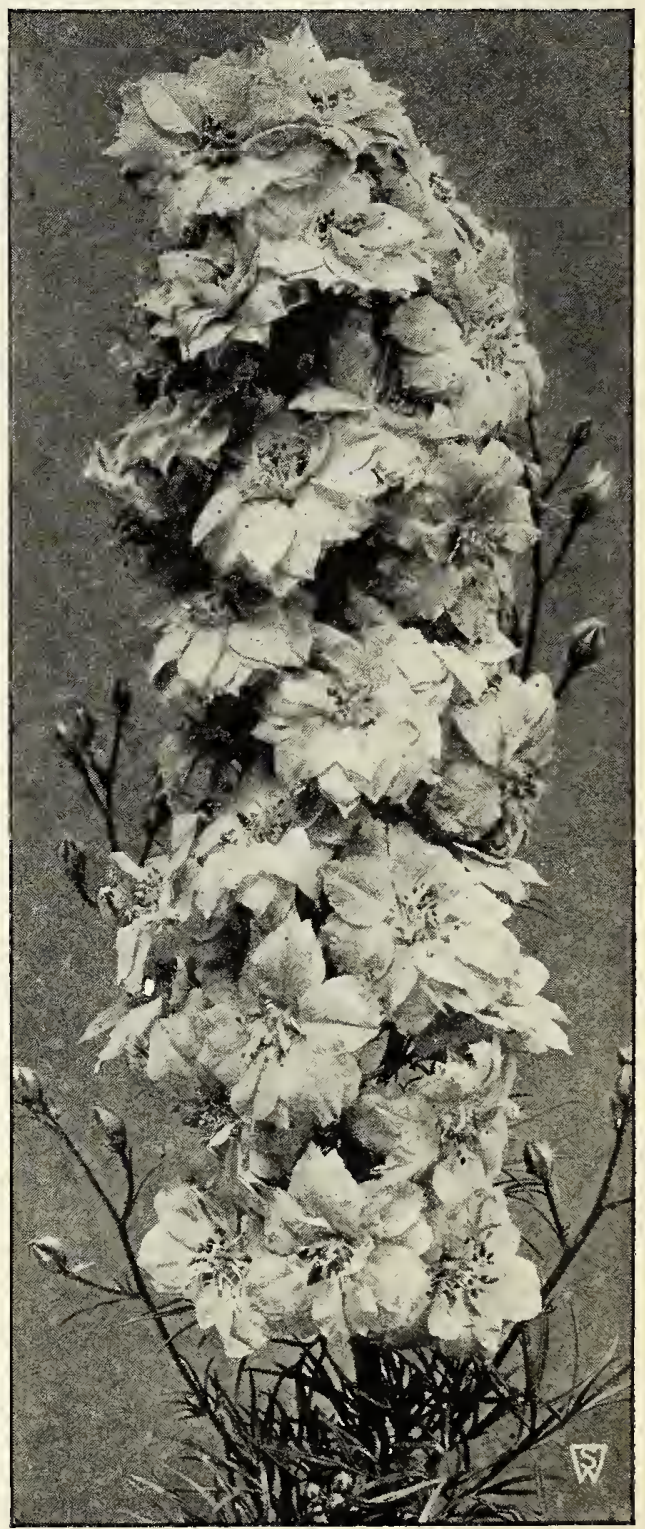

Larkspur, Double Stock-flowered 


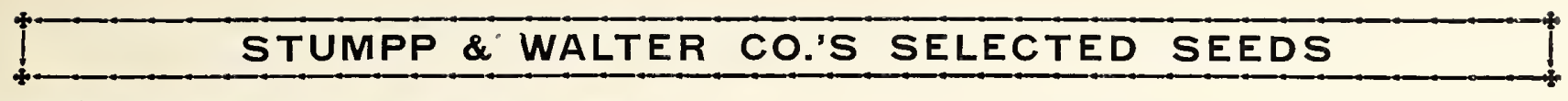

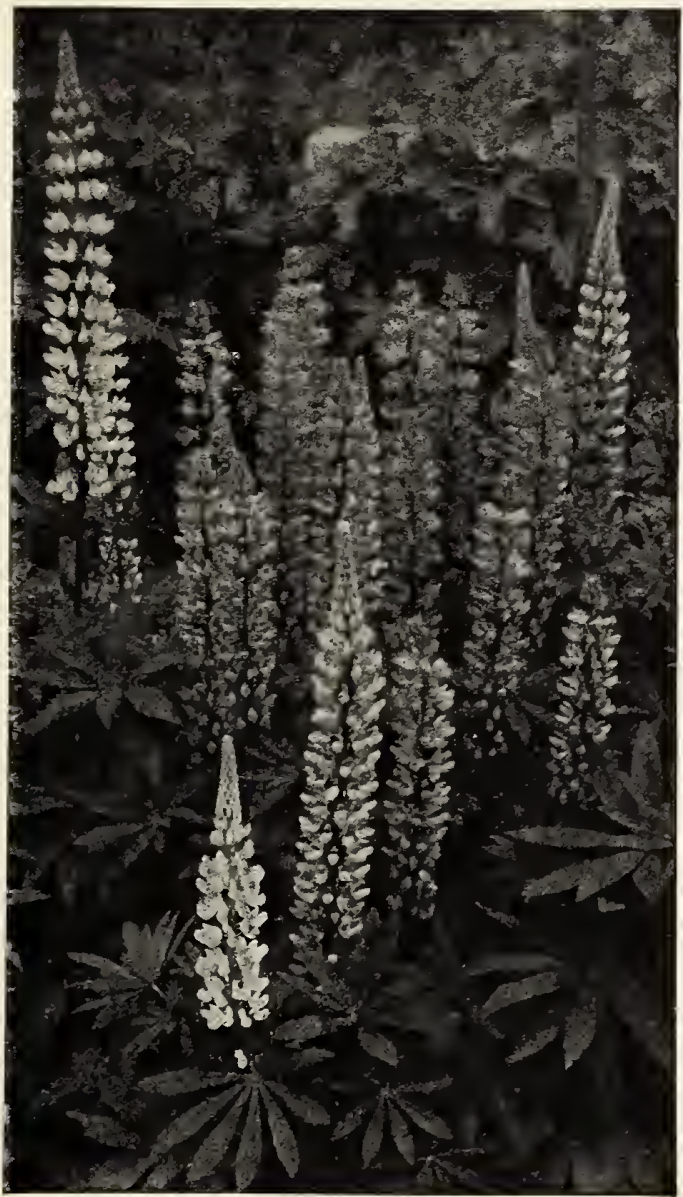

Lupinus

\section{Dwarf French Marigolds}

Few annuals are as effective as the French Marigold, or bloom for as long a period. They form compact bushes I foot high, and are unequaled for borders or beds.

Golden Ball. Double, pure golden yellow.

Legion of Honor (Little Brownie). A charming single-flowering Marigold forming dense, compact bushes about 9 inches high. They begin to bloom in June and continue until frost. The flowers are golden yellow marked with a large blotch of velvety crimson at the base of each petal.

Each, pkt. 25 cts., $1 / 402$. $\$ 1$

Mixed. Pkt. $25 \mathrm{cts} ., 1 / 4 \mathrm{OZ} \$ I$.

\section{MATTHIOLA \\ Evening-scented Stock}

Bicornis. This old-fashioned annual has no beauty to recominend it, the flowers being a dull purplish lilac, but it is well worth growing for the entrancing fragrance which it emits during the evening. I ft. Pkt. Io cts., $1 / 4 \mathrm{Oz}$. $50 \mathrm{cts}$.

\section{MOMORDICA}

\section{Balsam Apple; Balsam Pear}

Luxuriant annual climbers, with large leaves, making dense shade. The flowers are followed by ornamental, large fruits of orange or copper color, which burst and expose an interior of red, which is highly effective. I5 to 20 feet.

Balsamina (Balsam Apple), Orange fruits. Pkt. Io cts., oz. $75 \mathrm{cts}$. Charantia (Balsam Pear). Coppery scarlet fruits. Pkt. Io cts., oz. 75 cts.

\section{LUPINUS}

\section{Lupine}

This very interesting class of plants is of easy culture and produces beautiful Thes and pea-shaped flowers. It should be more generally cultivated. The following annual varieties may be sown out in the open in May and as plants grow, thin out, leaving about I foot between the plants.

White
Rich Blue $\quad$ Each, pkt. $10 \mathrm{cts}$., $0 z .50 \mathrm{cts}$.

Rose

Each, pkt. 10 cts., oz. 50 cts.

. \& W. Co.'s Finest Mixture. A splendid mixture of the Annual Lupines for cutting. Pkt. Io cts., oz. 50 cts.

\section{MARIGOLD}

The African and French Marigolds are old favorite free-flowering annuals of Thy culture; both are extremely effective. The former have uniformly large, borders; the latter are dwarfer in growth, with beautifully striped flowers, and are better suited for bedding purposes and for pot culture. They succeed best in a

\section{Tall Double African Marigolds}

emon Quilled. Deep double lemon flowers daintily quilled. Pkt. Io cts.,

Giant Show Mixture. Pkt. 25 cts., $1 / 40 z . \$ I$.

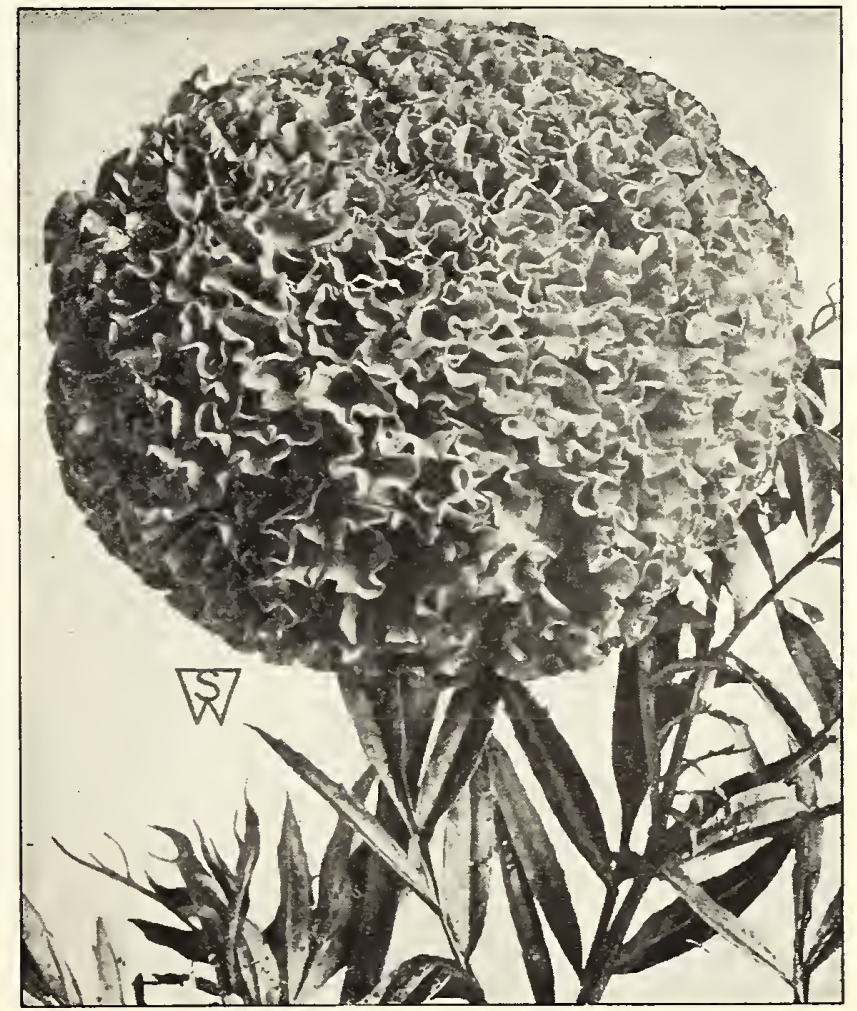

African Marigold 


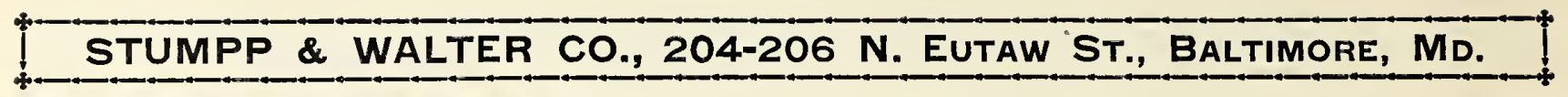

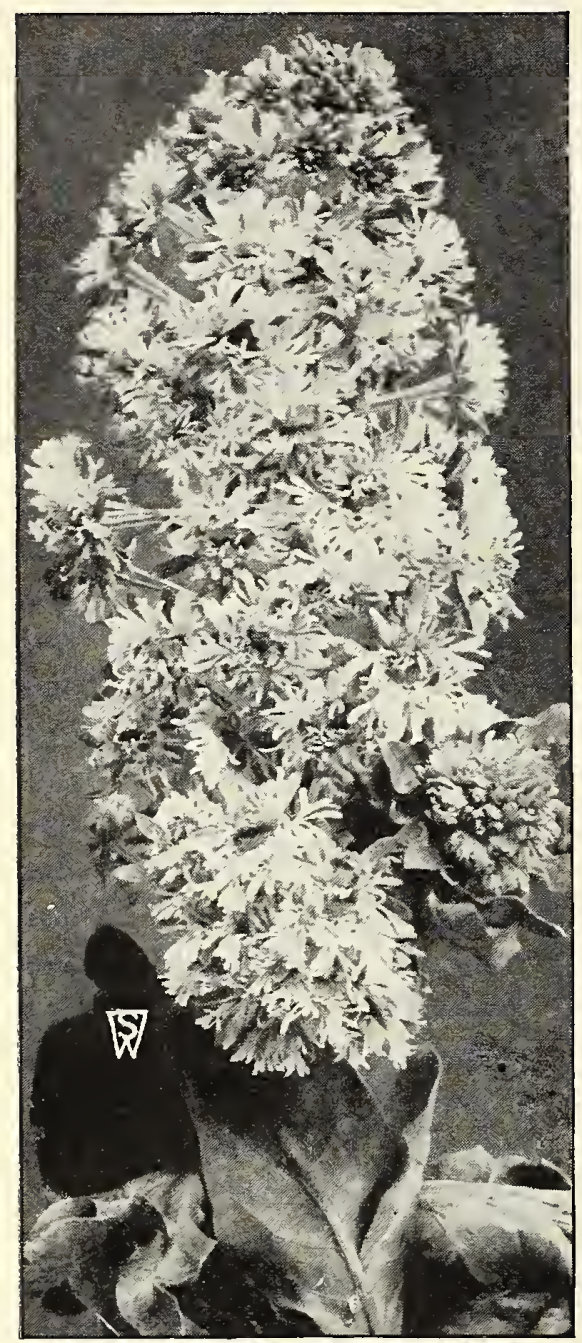

Mignonette

\section{MIGNONETTE}

\section{Reseda}

Well-known little hardy annual plants, with sweet-scented flowers, at home everywhere, either in the greenhouse, garden or sitting-room.

Allen's Defiance. This gorgeous Mignonette has qualities heretofore unknown in largeflowering varieties, being deliciously fragrant. When grown under favorable conditions and with proper care, its spikes will be from $\mathrm{I}_{2}$ to $\mathrm{r} 5$ inches long. The indivídual florets are of remarkable size and stand out boldly, forming a graceful as well as compact spike. Its remarkable strength is accompanied by extraordinary keeping qualities; the spikes have been kept in a vase three weeks after cutting, retaining their grace and fragrance untíl every bud opened Pkt Io cts, $1 / 40 z .50 \mathrm{cts}$.

Improved Large-flowering. Pkt, ro cts, $1 / 4 \mathrm{OZ} 25 \mathrm{cts}$

Machet. A dwarf French variety. with broad spikes of very fragrant red flowers; one of the best varieties for either garden or pot culture. Pkt, Iocts, $1 / 4 \mathrm{Oz} .50 \mathrm{cts}$

\section{NEMOPHILA}

Splendid annuals for garden decoration, bright-colored flowers, in shades of blue, white, and violet. I foot.

Finest Mixed. Pkt. ro cts

\section{NICOTIANA}

Affinis. An annual with sweetscented, pure white, star-shaped flowers, 3 inches across, blooming continually. 2 to 3 feet Pkt. ro cts., $1 / 402.25$ cts.

\section{NIGELLA}

Damascen a, Double Mixed (Love-in-a-Mist), Pretty garden annuals with feathery green foliage, in which large, double. charming blue or white flowers are set. I to 2 feet. Pkt. IOC $\mathrm{I} / 4 \mathrm{Oz} 3 \mathrm{O} \mathrm{cts}$.

Miss Jekyll. A lovely variety with cornflower-blue blossoms, splendid for cutting Hardy annuals. About 2 feet. Pkt to cts., $1 / 40 z$. 50 cts.

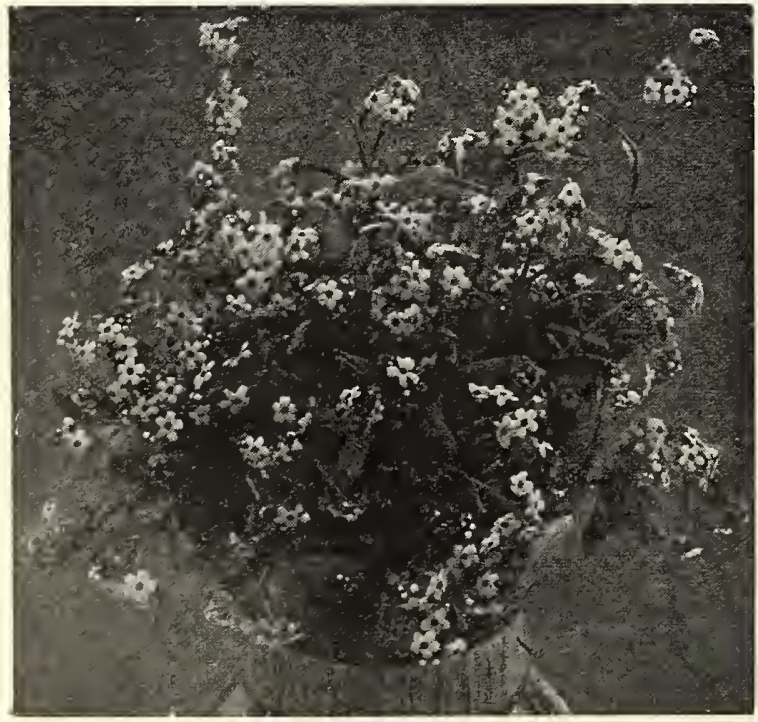

Forget-me-nots

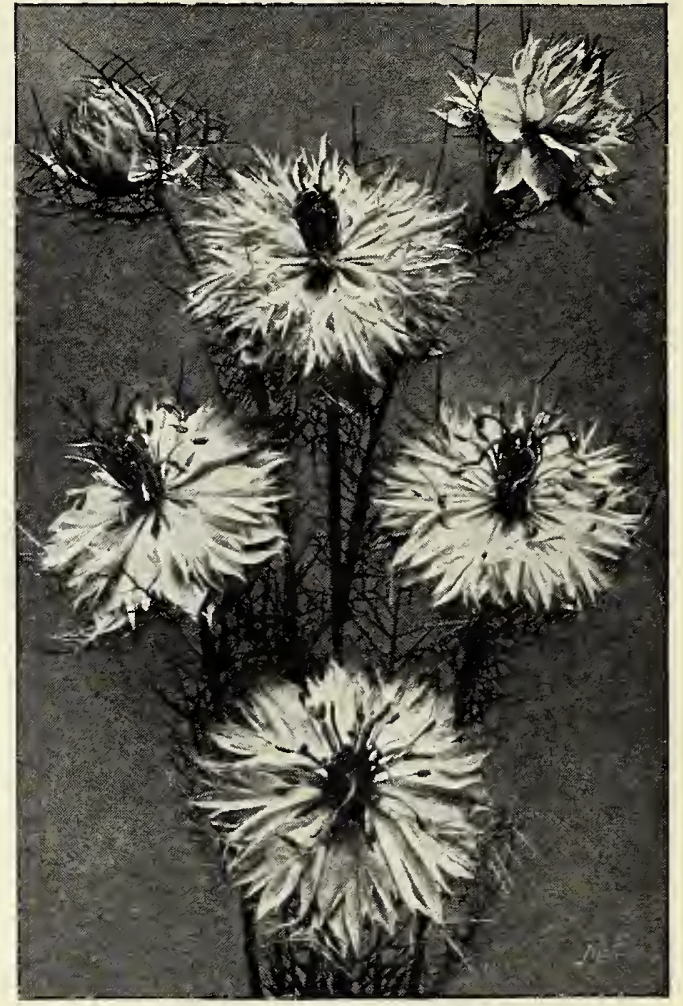

Nígella, Miss Jekyll

\section{MYOSOTIS}

\section{Forget-me-not}

Few spring flowers are more admired than the lovely Forget-me-not which is especially effective for mass planting. It is perennial and hardy if given slight protection through the winter. Seed may be sown any time from spring until mid-summer. The Alpestris varieties and Dissitiflora come into bloom in April, with the spring-flowering bulbs, etc. The Palustris sorts do not bloom till May, but continue till fall.

Alpestris, Royal Blue. Rich indígo-blue flowers. The finest Pkt. $\quad 1 / 40 z$. and most effective ciark blue variety, grows about 9 inches

hígh. .........................................

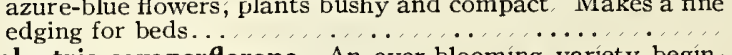

Palustris semperflorens. An ever-blooming variety beginning to flower in May and continuing until autumn. Large, clear blue flowers ín pretty sprays................ I5 2 oo

\section{NEMESIA}

We are pleased to offer a splendid strain of this beautiful half-hardy annual, principally the large-flowered varieties and one of the dwarf, compact sorts.

S. \& W. Co.'s Mixed. Rich mixture of all the lovely colors that come in this class of plants. Pkt. 25 cts., 5 pkts. \$1
Alpestris,Victoria. A favorite variety with fine heads of clear
azure-blue flowers, plants bushy and compact Makes a fine 


\section{Stumpp \& Walter Co.'s Superb Nasturtiums}

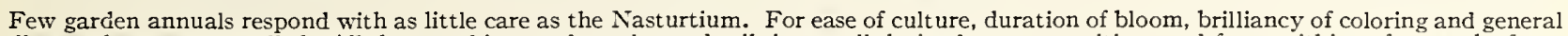

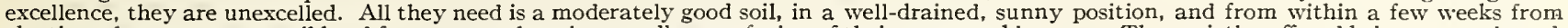

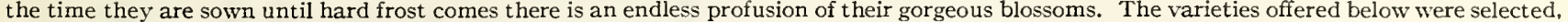
after exhaustive trials, from a very large number of sorts as being the best and most distinct.

\section{NEW LARGE -FLOWERING, TALL AND DWARF}

We have arranged with a grower, who has made growing Nasturtiums a specialty, to grow this Giant-flowering strain for us. The plants are strong and vigorous, with very large, bright green leaves, measuring from 5 to 8 inches across. The flowers, which are very numerous, measure 3 inches in diameter, and are borne on long stems well above the foliage. They are exquisitely formed, with overlapping, crinkled

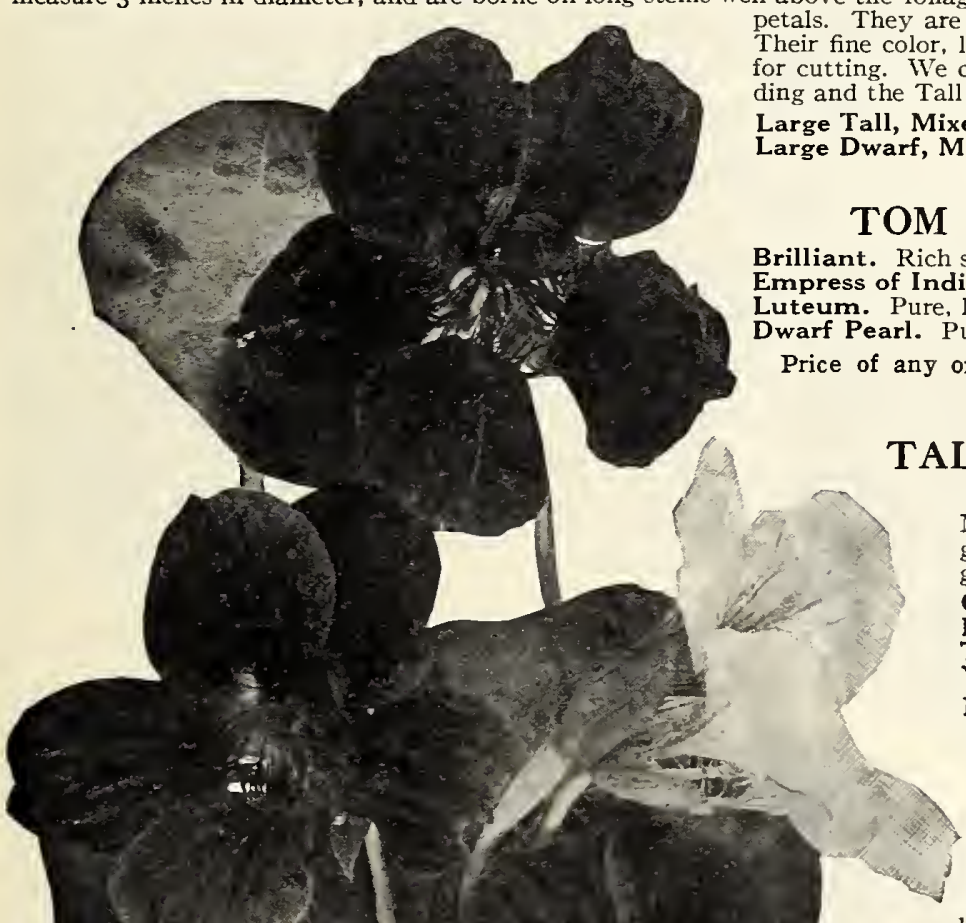
petals. They are produced in great numbers and have a most striking effect. (hem valuable ding and the Tall Climbing kinds.

Large Tall, Mixed. Pkt. I5 cts., oz. $25 \mathrm{cts}$., I/4lb. $75 \mathrm{cts} ., 1 \mathrm{lb} . \$ 2$.

Large Dwarf, Mixed. Pkt. I 5 cts., oz. $25 \mathrm{cts}$., 1/41b. $75 \mathrm{cts}$., 1b. $\$ 2$.

\section{TOM THUMB DWARF OR BEDDING}

Brilliant. Rich scarlet.

Empress of India. Brilliant crimson; dark foliage.

Luteum. Pure, light yellow.

Price of any of the above named Dwarf sorts, pkt. $10 \mathrm{cts.}$. $0 z .20$ cts., $1 / 4 \mathrm{lb} .60 \mathrm{cts}$.

\section{TALL OR CLIMBING VARIETIES}

Elegant and luxuriant climbers for verandas, trellises, etc. May be used to cover unsightly railings and to trail over rough ground with fine effect. The seed-pods can be gathered while green and tender for pickling; 6 to Io feet.

Crimson. Rich and velvety.

King Theodore. Deep crimson-maroon, dark foliage.

Tall Pearl. Creamy white.

Yellow. Pure yellow.

Price of any of the above named Tall sorts, pkt. 10 cts., oz. 20 cts., $1 / 4 \mathrm{lb}$. 60 cts.

\section{POPPIES}

Annual Poppies should be sown as early as possible in the spring where they are to remain, as they do not transplant readily. It is advisable to mix the seed with builders' sand, using about twenty-five times as much sand as seed, and then carefully broadcast seed on the surface of the ground and firm well. Plants should be thinned out to stand about 4 inches apart for best results. Seed may be sown in rows also and in succession up to the middle of May. It is advisable to pick flowers just as they are expanding as they last longer; removing the old blooms from plants will help lengthen the flowering season.

\section{Single Annual Varieties}

Shirley, Carmine Shades. A selection of all the shades of carmine.

Shirley, Rose Shades. A selection of rose-color shades.

Shirley, Salmon Shades. A selection of salmon shades.

Shirley, White Shades. A selection of white shades.

Shirley, Wild Rose. One of the finest of the Shirleys, the flowers of which are best described as a pure wild-rose-pink.

Shirley, Mixed. We have prepared a mixture of these above, as well as the deeper shades of scarlet to rich crimson.

Each, pkt. 10 cts., $1 / 4$ oz. 50 cts., oz. $\$ 1.50$

English Scarlet (Flanders). The common scarlet Field Poppy of Europe. Plt. Io cts., $1 / 40 z .25 \mathrm{cts}$.

\section{Double Annual Varieties}

The Double Annual Poppies require the same cultural treatment as the Shirley. They are excellent to grow for cutting. For best results plants should be thinned out to stand 8 inches apart. $\quad$ Pkt. $1 / 40 z$.

Carnation-flowered. Splendid double, fringed flowers.

S. \& W. Co.'s Large flowering Nasturtiums

Mixed colors.

Peony-flowered. Large, showy, double globular flowers, resembling a double Peony.

Mixed colors ...................... Io 
STUMPP \& WALTER CO., 204-206 N. EUTAW ST., BALTIMORE, MD.

\section{STUMPP \& WALTER GO.'S GIANT PANSIES}

This very popular annual needs little description. Good results may be obtained from sowing seed in April in a light, cool, but well-moistened soil, enriched with a slight amount of barnyard manure or fine ground bone. Sow seed in drills, covering them five

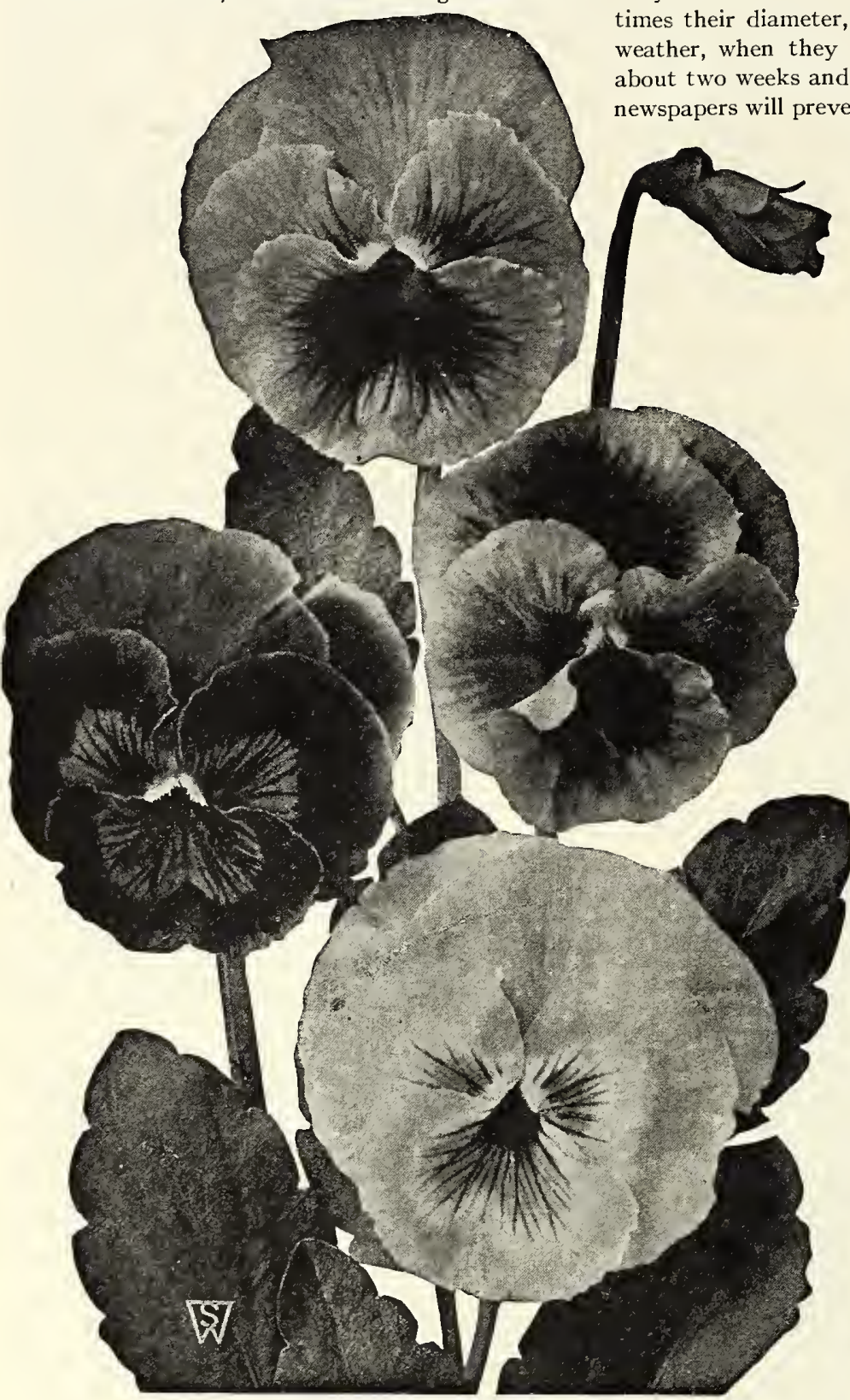

S. \& W. Co.'s Giant Pansies

PORTULACA (Sun Plant)

One of our finest annual plants, of easy culture, thriving best in a rather ricn, light loam or sandy soil, and luxuriating in an exposed sunny situation. The flowers are of the richest colors and are produced throughout the summer in great profusion. Fíne for massing in beds, edgings on rockwork, and frequently used to sow broadcast over sunny banks, etc. In any case, it is well to mix the seed with three or four times its bulk of dry sand or soil, which permits of even and easy distribution. 6 inches.

Grandiflora, Single, finest mixed. Pkt. Io cts., $1 / 40 z .40 \mathrm{cts}$. Grandiflora, Double, finest mixed. Pkt. Io cts., 1/40z. \$I.25. transplant to a distance of I foot apart. Where greenhouse and coidframe facilities are at hand, sow in July or August and protect plants during winter.

\section{Pansies in Mixture}

Our Pansy Mixtures are prepared in our Flower Seed Department by an expert who has a thorough knowledge of the finest sorts extant, and is done in a very careful manner. Our Pansies have been grown throughout the United States, by leading florists, many of whom have repeated their orders every year, thereby g.ving their unqualified indorsement to our famous strain.

\section{S. \& W. Co.'s Exhibition Strain}

This mixture of Giant Pansies has been prepared of the finest varieties grown; blooms of gigantic size, splendid texture; the plants of robust constitution hold their majestic blooms well above the foliage. Every conceivable color and combination of colors has been included. Pkt. 50 cts., I/40z. \$3.50, oz. \$10.

S. \& W. Co.'s Special Mixed. Pkt. Io cts., I/4oz. \$I, oz. $\$ 3 \cdot 50$.

\section{Giant Pansies in Separate Colors}

Giant Adonis. Soft lavender-blue. Pkt. I5 cts., I/4oz. $\$ \mathrm{I} .5 \mathrm{O}, \mathrm{Oz} . \$ 5$

Giant Dark Blue. Deep blue. Pkt. I5 cts., I/4oz. $\$$ I.5O, oz. \$5.

Giant Fire King. Mahogany and gold. Pkt. I 5 cts, $1 / 4 \mathrm{Oz} . \$ 1.25, \mathrm{Oz} . \$ 4$.

Giant King of the Blacks. Black. Pkt. I 5 cts., I $/ 4$ Oz. \$I. 50 , oz. $\$ 5$.

Giant Snow-White. Pkt. I 5 cts., I/4oz. $\$ 1.25$, oz. $\$ 4$.

Giant Pure Golden Yellow. Pkt. I5 cts., $1 / 4 \mathrm{oz}$. \$I. 5o, oz. \$5.

\section{PHYSALIS (Chinese Lantern Plant)}

Franchetii. Hardy perennial forming dense bushes about 2 feet hígh, producing bright orange-scarlet lantern-like fruits. May be had in flower first year from seed if sown early; the fruits are often displayed in florist shops and are very interesting, and of splendid decorative value. Pkt. 25 cts., 5 pkts. \$I.

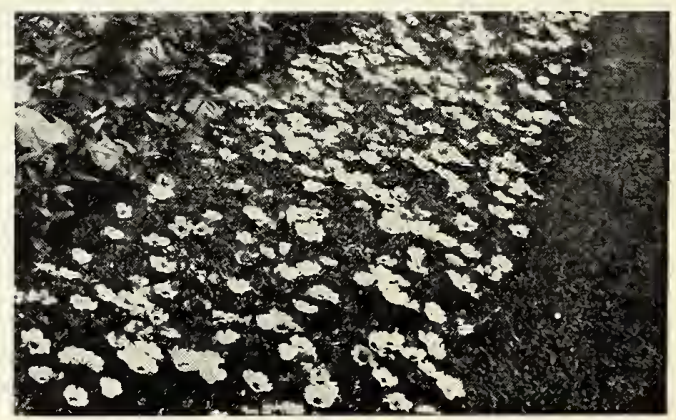

Portulaca 


STUMPP \& WALTER CO.'S SELECTED SEEDS

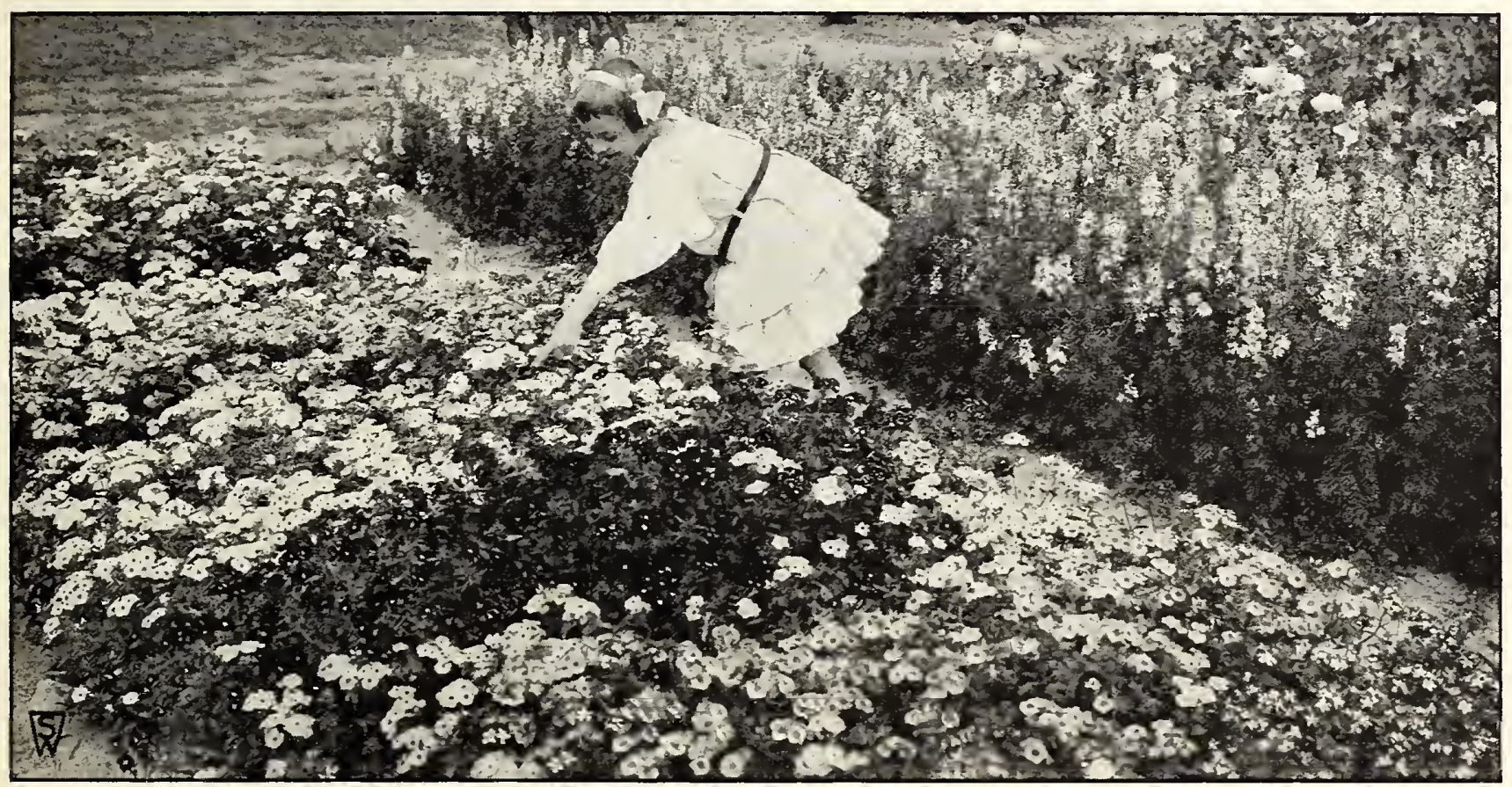

Phlox Drummondii in foreground

\section{PHLOX DRUMMONDII (Hardy Annual)}

One of our best annuals, flowering freely all the summer. For richness of color they cannot be surpassed. They are invaluable for beds and ribbon-gardening, therefore no garden should be without them. They should be sown outdoors in May, in a situation well open to the sun, and they will flower and be a mass of color in July and continue until late autumn. Seeds may be sown in a hotbed in March and flowers be had in June.

\section{Large-Flowering Tall Varieties}

This is the finest type, having the largest heads of bloom as well as the largest individual flowers; of strong, sturdy growth, attaining a height of about 15 inches.

Brilliant. Finest crimson.

Chamois-Rose. Shell-pink

Rosea. Enchantress-pink.

Scarlet. Rich scarlet....

White. Pure white

Isabellina.' Tea-rose yellow

Finest Tall Mixed

\begin{tabular}{|c|c|c|c|}
\hline $\begin{array}{l}\mathrm{Pk} \\
\text { So }\end{array}$ & & & \\
\hline & I 5 & I & $\mathrm{OO}$ \\
\hline & IO & & 75 \\
\hline & IO & & 75 \\
\hline & IO & & 75 \\
\hline & I 5 & I & 00 \\
\hline & ro & & \\
\hline
\end{tabular}

\section{Large-Flowering Dwarf Varieties}

This type resembles the tall sorts offered in size of blooms but the plants are dwarfer in habit.

Chamois-Rose. Shell-pink

Pkt. $1 / 40 z$.

Defiance. Brilliant crimson

Fireball. Scarlet

Purple

Snowball. Pure white

Surprise. Vermilion, white center

Finest Dwarf Mixed.

tar of Quedlinburg. -Dwarf; star-shaped flowers; a novel variety.

Mixed colors, pkt. Io cts., $1 / 402.75$ cts.

\section{PETUNIA}

The Petunias cannot be equaled by any other plants for outdoor decoration. Will flower the first season, even if sown in open ground, but usually not before June. These sown in the house or hotbed in April will bloom in June and be larger and finer plants. Half-hardy annual.

\section{GIANT-FLOWERING FRINGED PETUNIAS}

Under this heading we have listed the finest possible varieties of the now popular large-flowering Fringed Petunias. Whether desired for bedding, cutting or general display, the varieties listed are the best by test of the Fimbriata, or fringed large-flowering class.

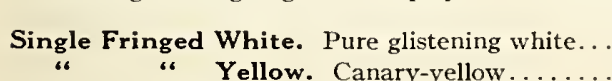

" " " " Rose. Brilliant rose...

“ Crimson. Dazzling crimson.
Pkt.

25

25

25

25

Single Fringed Mixed. A mixture of best fringed varieties including with the above many new colors and shades....... \$ 25

Double Fringed Mixed. A superb mixture of the finest double-

fringed varieties............................. 50

\section{SINGLE BEDDING VARIETIES}

Balcony Blue. A splendid free-flowering type, either for bed- Pkt. ding or window-boxes, vases, hanging-baskets, etc. Flowers

average 3 inches across and are of a rich indigo-blue......... so 25

Balcony Rose. Brilliant rose-pink................... 25

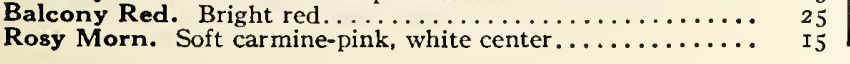

Snowball. An excellent, compact variety, producing pure Pkst. satiny white flowers throughout the entire season; very dwarf. \$o I5 Howard's Star. Rich crimson with distinct white star in the center. . E Ellesmere. Dark rose, with fine white throat.

Special Bedding, Mixed. Select, bright colors....1/40z. 40c. 
STUMPP \& WALTER CO., 204-206 N. EUTAW ST., BAL MMORE, MD.

\section{SALPIGLOSSIS (Painted Tongue)}

Few annual flowers contribute such a wealth of bioom from summer until cut down by frost. It is only of recent years that American gardeners have become better acquainted with this delightful annual. As a cut-flower it has become highly prized. The funnel-shaped flowers, facing upward, revealing their exquisite markings of either gold or silver veins running through the groundwork of the flowers, and their orchid-like appearance, make them instant favorites.

For best results sow seed in a hotbed or sunny window, and when all danger of frost is past, place in the garden, allowing $\delta$ inches between the plants.

\section{New Hybrids of Salpiglossis superbissima Orchid-flowering}

Brown and Gold

Crimson

Light Blue and Gold

Primrose

\section{Purple and Gold \\ Scarlet and Gold \\ Rose and Gold \\ Velvety Violet}

Each, pkt. 15 cts., $1 / 40 z .75$ cts., oz. $\$ 2.50$

COLLECTION: One pkt. each of above 8 colors, $\$ 1$

Finest Mixed. All shades-Scarlet, Pink, Yellow, and Violet, pkt. Io cts., $1 / 40 z .50$ cts., oz. $\$$ I. 75 .

\section{SALVIA}

One of our most handsome summer- and autumn-flowering plants growing into compact bushes about 3 feet high and literally ablaze with brilliant flowers; very effective for massing on the lawn and for garden decorations. Half-hardy perennial.

Splendens (Scarlet Sage). Beautiful bright scarlet; 3 feet. Pkt. Io cts., $1 / 40 z$. 60 cts.

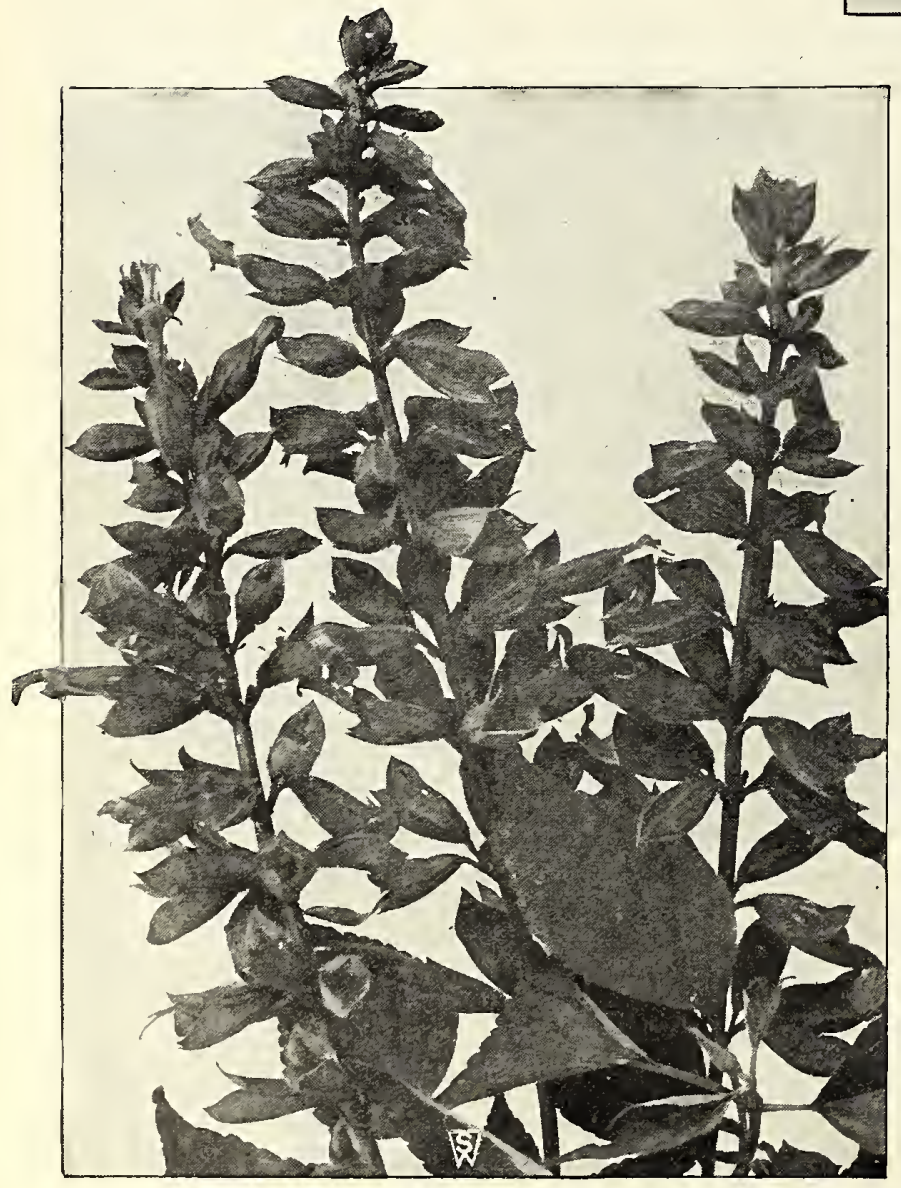

Salvia splendens (Scarlet Sage)

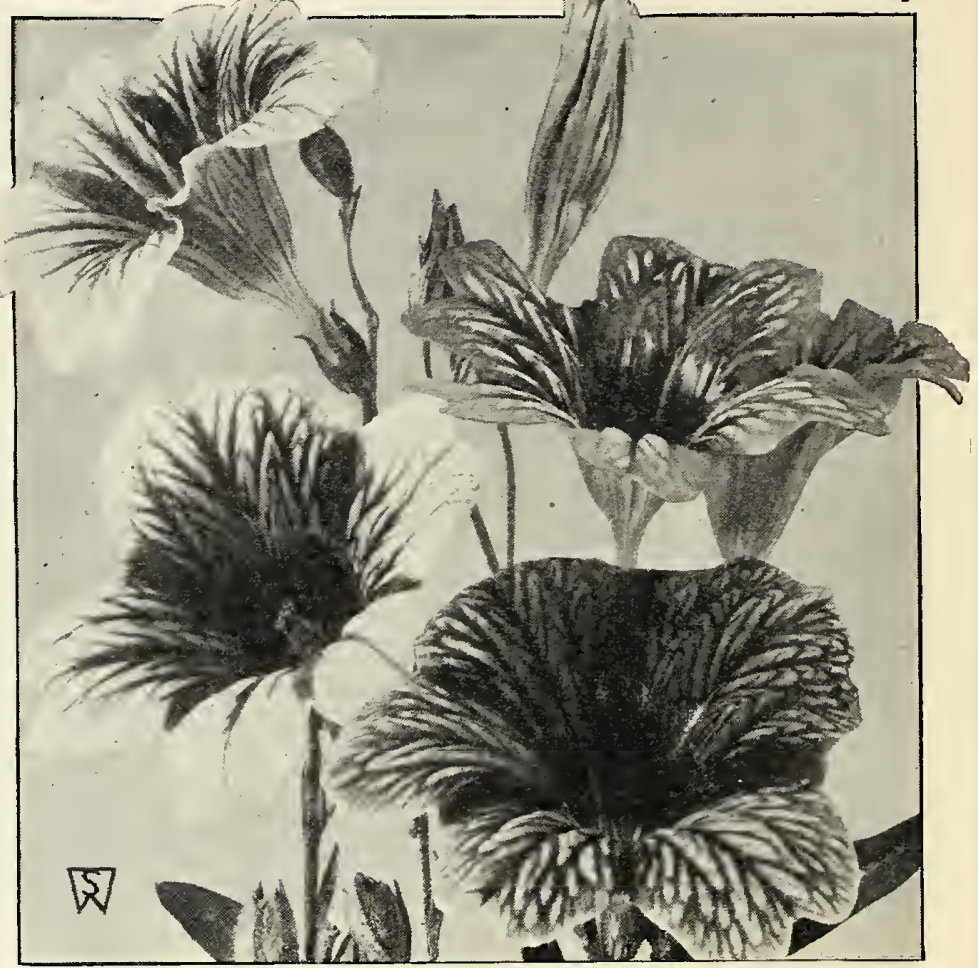

Salpiglossis superbissima (Orchid-flowering)

Bonfire. The plants grow into very compact oval bushes, about $21 / 2$ feet high and produce long spikes of brilliant scarlet flowers. Gorgeous effects can be produced with the Bonfire Salvia massed on the lawn or in the garden, or planted in rows along a sunny drive; where the brilliant scarlet is simply dazzling. Pkt. Io cts., $\mathrm{I} / \mathrm{OOZ}$. $\$ \mathrm{I} .5 \mathrm{O}, \mathrm{I} / 2 \mathrm{Oz}$. $\$ 2.5 \mathrm{O}$, oz. $\$ 5$

Ostrich-Plume. The Ostrich-Plume Salvia is the most beautiful of all Salvias of recent introduction. The habit of the bush resembles the Splendens type but, unlike Splendens, produces a plume. The bush is well covered with these plumes of the most intense, dazzling scarlet. As a cut-flower for vases one plume alone makes a delightful decoration. Comes 75 per cent true from seed, and is as hardy as the other Salvias. Pkt. 25 cts., 5 pkts. $\$ \mathrm{I}$.

Patens (Blue Sage). In color this is as blue as the "Scarlet Sage" is red; unlike the latter, however, it is not useful for bedding, but is a beautiful plant for the border or greenhouse; tender perennials. 2 feet. Pkt. 25 cts.

\section{SCABIOSA}

Mourning Bride; Pin-Cushion Flower; Sweet Scabious

These beautiful hardy annuals are in great demand. They grow about $21 / 2$ feet high and bloom from early in July without interruption until cut down by the frost. As a flower for cutting they are very popular. The various shades are extremely charming, but are equally well adapted for borders or beds, where they display themselves very effectively. Seeds should be sown any time in the spring

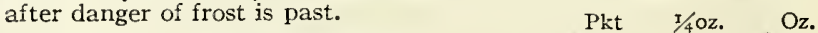
Azure Fairy. Clear lavender-blue..........\$0 Io \$o 50 \$I 50 Crimson. Brilliant and dazzling........... Io 50 I 50 King of the Blacks. Velvety purplish black.. to 50 I 50 Rose. Strong shade of pink............. Io 50 I 50 Shell-Pink. Delicate light tint............ Io 50 I 50 White. Pure white................... I0 50 I 50

COLLECTION: One pkt. each of above 6 varieties, $50 \mathrm{cts}$.

Tall Double Mixed ................... Io 30 I 00 Dwarf Double Mixed................... Io 30 I 00

\section{SCARLET RUNNER VINE}

This Bean produces a rapid-growing vine and makes clusters of showy scarlet flowers. Hardy annual. I5 feet high. Oz. Io cts. 

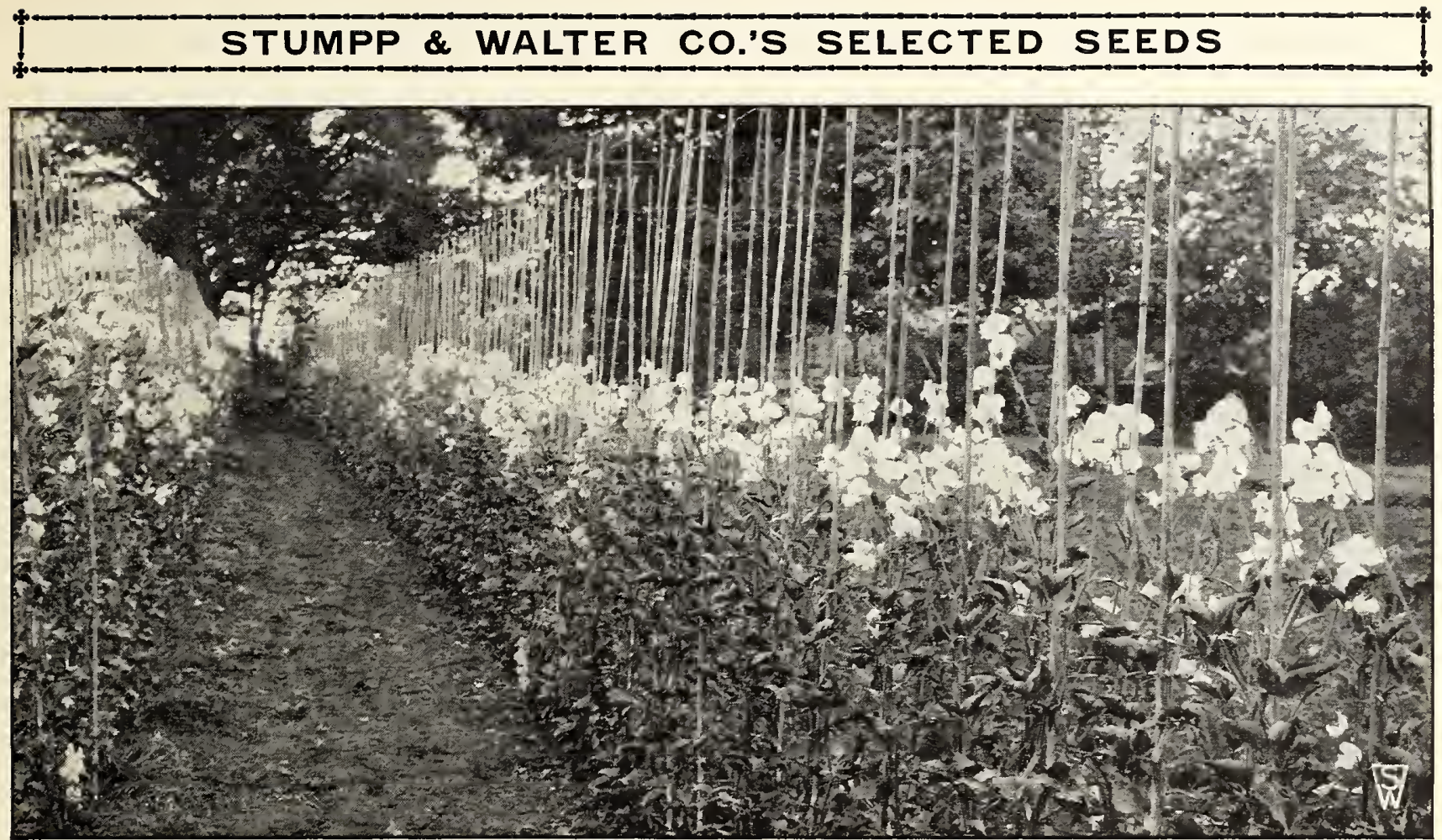

\section{Stumpp \& Walter Co.'s Sweet Peas SUMMER-FLOWERING SPENCER VARIETIES}

\section{Culture of Sweet Peas}

Sow seed as soon as the ground can be worked in the spring. Dig a trench about a foot wide and deep, and fill in with 6 inches of well-rotted stable manure; tread down firmly and replace the good garden soil. Draw a single straight line in the middle of the prepared surface, about 3/4inch deep; sow seed at even distances of about 3 inches and cover. When the plants grow about 3 to 5 inches high, thin out, leaving the plants 6 inches from each other. (Experts who raise for exhibition thin out to one foot.)

The cutworm is one of the greatest enemies of Sweet Peas, attacking the young shoots just as they come up. At the first appearance of this pest, a good sprinkling of lime over the row sometimes helps to exterminate it. As soon as the vines reach a lieight of about 8 inches, proper trellis or other supports should be provided.

The Sweet Pea is a moist ure-loving plant, and by the month of May the plants will require water. In order that the water may be retained by the soil and get to the roots, as well as to keep them cool, it is advisable to use a mulch of old stable manure and soak well with hose each or every other day, as needed.

Austin Frederick Improved. Fine, large, bright Pkt. lavender flowers, produced freely on long stems. An

Oz. Hebe. This mammoth Sweet Pea has immense, bright Pkt.

$\mathrm{Oz}$. excellent variety.

Avalanche. A very large flower, strong and heavy.

I 5 \$o 75 and of the purest white.

Blanche Ferry. Still a great bicolor variety and considered among the best. The standards are bright pink and the wings pure white - a lovely contrast. .

Charity. This is, without a doubt, the finest rich brilliant crimson which does not burn in the sun. A vigorous grower, the exquisitely waved flowers are usually produced in fours on long gracef ul stems.

Constance Hinton. Still considered the finest blackseeded white.....................

Fortune. The standard is violet and the wings are dark blue a lovely combination

Gold Crest. The flower is orange, and over all is a beautiful salmon sheen-truly an art color in a fine flower of great substance.

Hawlmark Lavender. Without a doubt the finest pure lavender as yet introduced. The flowers are of the largest size.

Hawlmark Salmon-Pink. The color is very "alive," bright and satisfactory in both daylight and artificial light. A most useful Sweet Pea

I5 75

$15 \quad 75$

\section{I 00}

IO 50

IO 50

Royal Purple. Without a doubt this is the finest rich

Io 50 royal purple. A large-flowering variety, with many

I5 75 four-flowered sprays.

Tangerine Improved. This variety has been appropriately named-a deep orange, almost approaching the colors of the tangerine orange. Flowers of great size and well waved

I5 75 Warrior. The finest dark maroon in our list. Hawl mark Maroon is the other fine variety of this shade but shows more red in the maroon, while Warrior shows more chocolate.

Youth. A large white flower, but on the edges of wings and standard is a blushing of delicate rose. .

I5 \$0 75

25 I 00

Mrs. Tom Jones. Until the introduction of this beauthere was no color like it in blues. The waved, and of a uniform bright delphinium-blue. A leader in its color at all Sweet Pea exhibitions. . .

50

I 00
GRAND PRIZE MIXTURE Giant Summer-flowering Sweet Peas
This is a combination of the best varieties of the Spencer Sweet Peas, and includes every described color and shade, good care being taken to have all the best varieties.

Packet .........
Ounce
Quarter-pound
Half-pound.....
Pound ..........

Packe

Pound.

$\begin{array}{rr}\$ 0 & 10 \\ 25 \\ 85 \\ 150 \\ 250\end{array}$




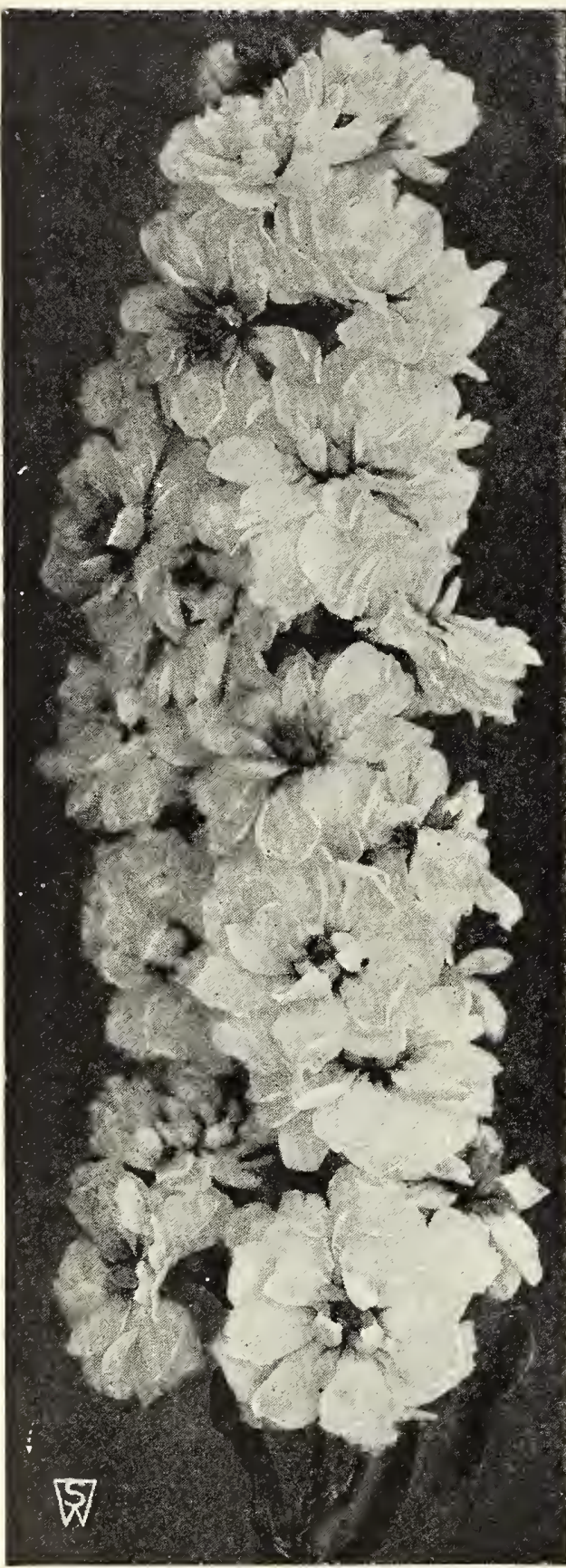

S. \& W. Co.'s Giant Perfection Stocks

\section{THUNBERGIA (Black-Eyed Susan)}

Beautiful, rapid-growing annual climbers, preferring a warm, sunny situation; used extensively for hanging-baskets, vases, low fences, etc. Very pretty flowers; buff, white, orange, etc. 4 feet.

Mixed Colors. Pkt. Io cts., 1/40z. 50 cts.

\section{TORENIA}

Fournieri. A very fine annual; splendid for vases, hanging-baskets, borders, etc. Sky-blue flowers, with bright yellow center. Pkt. Io cts.

\section{STOCKS}

These popular flowers are easily grown, and are so highly fragrant and of such great beauty, and have so many good qualities, that they deserve a place in every garden. They should be given good rich soil to grow in, and will amply reward good treatment with remarkably large pyramids of bloom. The flowers represent a great diversity of color. The Tall Perfection and Dwarf Bouquet Stocks are great improvements over the Gilliflowers of the olden times, the flowers being much larger and more densely double, and there is also a much larger variety of colors and shades than there used to be.

\section{S. \& W. Co.’s Improved Giant Perfection}

These are an improvement on the variety offered as 'Ten-Weeks' Stock. Of splendid, pyramidal growth, freely branching from the main stem, giving an abundance of large spikes of double flowers from early summer until fali, and are used largely for cutting. 2 feet. Pkt. $1 / 80 z$.

White......... \$0 25 \$ 00 Light Blue ............\$0 25 \$I 00

Chamois-Rose................ 25 I 25 I 00

Fiery Crimson.................. 25 is 25 I 00

Purple.............. 25 I 00 Mixed............... 25 I 00

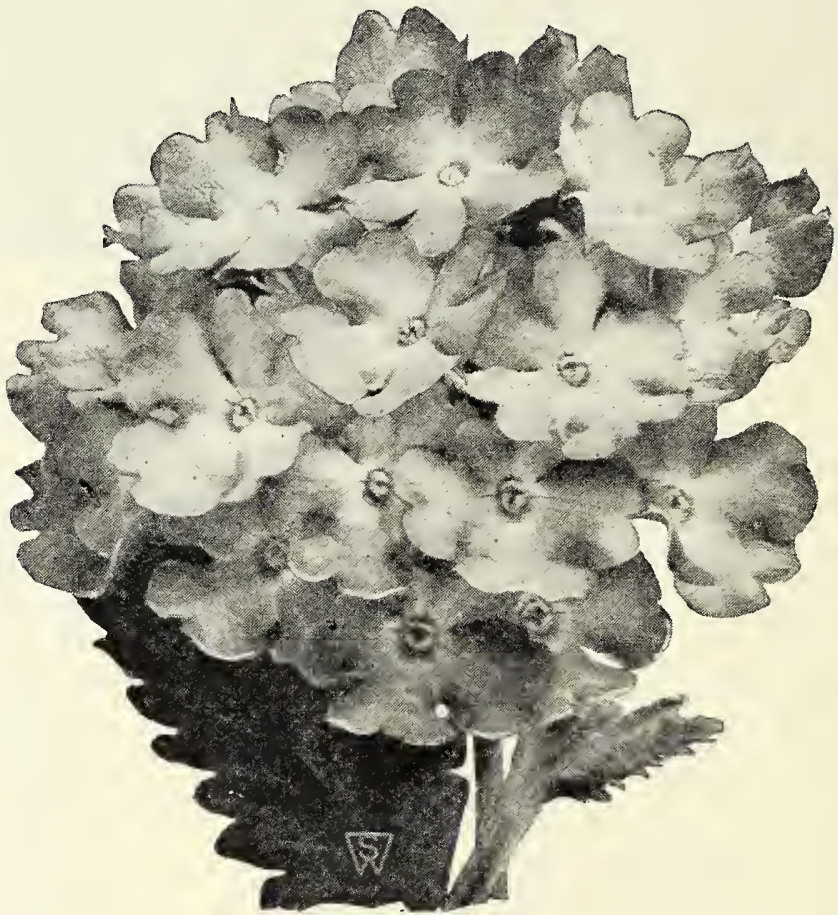

S. W. Co.'s

Mammoth Verbena

\section{MAMMO'TH VERBENAS}

The trusses and individual flowers are of the largest size, of brilliant colors, free bloming and of vigorous habit. For best and quickest results seed should be sown early in the house or hotbed, and transplanted to fiowering quarters in May. If sown outdoors in May, it blooms from the end of July on. Verbenas are better grown from seed than from cintings.

Pkt. Oz.

S. \& W. Co.'s Mammoth Defiance. Scarlet............. \$o io \$2 00

S. \& W. Co.'s Mammoth Blue. Deep blue................... Io 2 oo

S. \& W. Co.'s Mammoth Pink. Deep pink................... 10 2 oo

S. \& W. Co,"s Mammoth Yellow.

S. \& W. Co." Mammoth White. Pure white $\ldots \ldots$ Io 200

S. \& W. Co.'s Mammoth Mixed. Finest colors.................. Io 2 oo

Lemon Verbena (Aloysia citriodora). Every garden should have a few plants of this fragrant favorite. Its pale green, delightfully scented foliage goes well with any flower. Plkt. Io cts. 


\section{ZINNIA}

Youth and Old Age

The seed may be sown in a hotbed or sunny window and transplanted, or sown later in the open ground. The plants come into flower early in the summer and keep on blooming until hard frost.

\section{New Double Dahlia-flowered}

We are pleased to say we have been able to secure this Zinnia in separate colors this year. The plants are of the same vigorous habit as our Giant Double-flowering varieties which are listed below. They attain the height of 3 feet, producing mammoth flowers averaging 6 inches across by 3 to 4 inches in depth, similar in shape to the decorative dahlia. We consider them a fitting companion to our strain of Giant Double-flowering Zinnias.

Buttercup. Very large flowers of deep creamy yellow.

Crimson Monarch. Immense flowers of flaming crimson. Dream. Deep lavender-blue - a remarkable shade.

Exquisite. Light rose, with deep rose center.

Oriole. A striking two-color flower-orange and gold. Scarlet Flame. Bright scarlet, blended with orange.

Each, pkt. $25 \mathrm{cts}$., $1 / 4 \mathrm{oz} . \$ 1.50$, oz. $\$ 5$

COLLECTION : One pkt. each of above 6 colors, $\$ 1$

Mixed Dahlia-flowered Zinnias. Pkt. 25 cts., $1 / 40 z$. $\$ 1.50,0 z . \$ 5$.

\section{Giant Double-flowering}

Trials of this Zinnia sown in the open ground in April produced flowers 6 inches in diameter on plants 3 feet high. If sown in the open ground in April, thin out as soon as the plants are well up, leaving at least $I^{1} / 2$ feet each way, as they are robust growers, and require a large a mount of space to attain maximum size. The colors listed below a re pure in tone.
Flesh-Pink
Buttercup
*Salmon
*Rose
* Scarlet
*Yellow
* Crimson
Purple
*White

Each, pkt. 25 cts., oz. $\$ 2$

COLLECTION : One packet each of colors marked $* \$ 1 ; 1 / 40 z$. each of these, $\$ 3$

S. \& W. Co.'s Giant Double-flowering Mixed. We offer a well-prepared mixt ure of this greatly improved Zinnia and where our patrons are not desirous of growing them in separate colors, we suggest this mixture. Pkt. 25 cts., oz. \$2.

\section{Dwarf Double-flowering}

This type of Zinnia, while not so tall as our Giant Double-flowering varieties offered above, is a very satisfactory type for borders or cutting. Grows about $I^{1 / 2}$ feet high; flowers perfect.
Crimson

Lemon-Yellow

White

\section{Purple \\ Salmon-Rose}

Each, pkt. 15 cts., oz. $\$ 1.50$
Golden

Scarlet Mixed

\section{Tall Double-flowering Mixed}

This Zinnia is similar in height and form of plant to our Giant Double-flowering except the flowers which are about two-thirds the size. Pkt. Io cts., oz. \$I.

\section{Various Zinnias}

We offer below a selection of the various types of Zinnias, all of which, on account of the odd formation of the flowers, should be more generally cultivated.

Curled and Crested. The petals of this strain are curled and crested into the most fantastic and graceful forms. Our mixture includes all the brilliant shades. Pkt. Io cts., $1 / 4 \mathrm{Oz}, 50 \mathrm{C}$.

Picotee. The flowers of this new type are picoteed at the edge of the petals, with a color distinct from the body of the flower. Plants attain the height of $I^{1} / 2$ feet and bear prof usely. We offer them in a mixture of color. Pkt. $25 \mathrm{cts}$., 5 pkts. $\$ \mathrm{I}$.

Victory Quilled. This type of Zinnia has petals similar in form to the cactus-flowered Dahlia. The petals have a rather refined looking appearance and are very gracef ul. We offer them in a good mixture of color. Pkt. 25 cts., 5 pkts. $\$ \mathrm{I}$.

\section{Zinnia, Lilliput}

This variety forms a bush about I foot high, and is covered with small, very double flowers in profusion.

Finest Mixed. Pkt. Io cts., $1 / 40 z .50 \mathrm{cts}$.

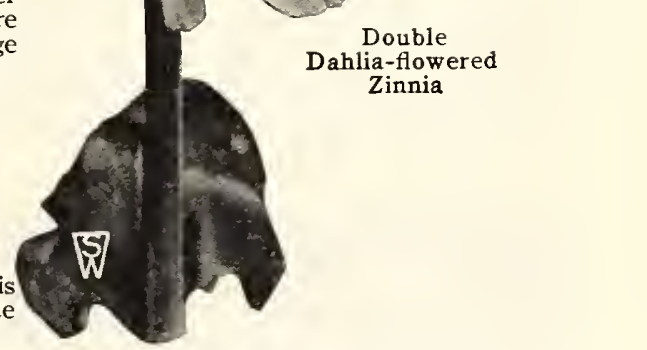

WALLFLOWER

These half-hardy perennial and annual Wallflowers are grown for early spring bedding and their delightful fragrance. Perennial sorts should be sown in autumn and carried over in coldframe; annual sorts may be sown indoors in March and will flower the first year from seed.

Early Parisian Annual. Golden, shaded orange-red. Pkt. Io cts.

\section{VIRGINIAN STOCKS}

Sown early, these pretty annuals are gay in the period between the spring and summer flowers, their fresh, bright colors in lines and beds producing a charming effect. May be sown like sweet alyssum; excellent for the border. White, Rose, or Mixed, pkt. Io cts., oz. 60 cts.

\section{Hardy Perennial Flowers}

A select list of the finest and newest varieties of Hardy Perennial Flower Seeds will be found on the three following pages. 


\section{Hardy Perennial Flower Seeds}

Perennials supply us with some of the most beautiful and interesting plants available for out-of-door culture. By judicious selection a succession of bloom may be obtained from spring until frost, with a wonderful range of color.

\section{NOTICE. About June 1 we will mail you a complete list of perennial seeds}

\section{ACHILLEA}

Ptarmica, The Pearl (Sneezewort). Hardy perennial. One of the best; bears a profusion of small, double, white flowers during the entire season. Fine for cutting. Height $2 \frac{1}{2}$ feet. Pkt. 25 cts., I $/ 80 z$. \$2.

\section{ACONITUM (Monkshood, or Wolfsbane)}

Napellus. A hardy perennial, growing in any good garden soil, producing long spikes of curiously shaped blue flowers. Well adapted for planting among shrubbery. Height 3 to 5 feet. Pkt. I5 cts., I/4OZ. $\$$ I.

Finest Mixed. All colors. Pkt. ro cts., 1/4oz. $\$$ r.

\section{ALYSSUM}

Saxatile compactum. Hardy perennial. Excellent rock or border plant, bearing bright yellow flowers from April to June. Height 9 inches. Pkt. I5 cts., oz. $\$ 2$.

\section{AQUILEGIA (Columbine)}

The Aquilegias are fine, free-flowering, hardy border plants. Seed may be planted in the open ground early in the spring, and will, in the case of single varieties, bloom the same season. Best results are obtained by planting in August, when they will come up early in the spring, making vigorous plants, blooming during late spring and early summer.

Giant Long-spurred, Mixed. A very excellent mixture of Columbines, comprising new and pleasing shades and combinations, effective and striking in the individual flowers, in many shades of lavender, blue, mauve, white, yellow, orange, scarlet, and bright rose-pink. Pkt. 25 cts., 5 pkts. $\$ 1$.

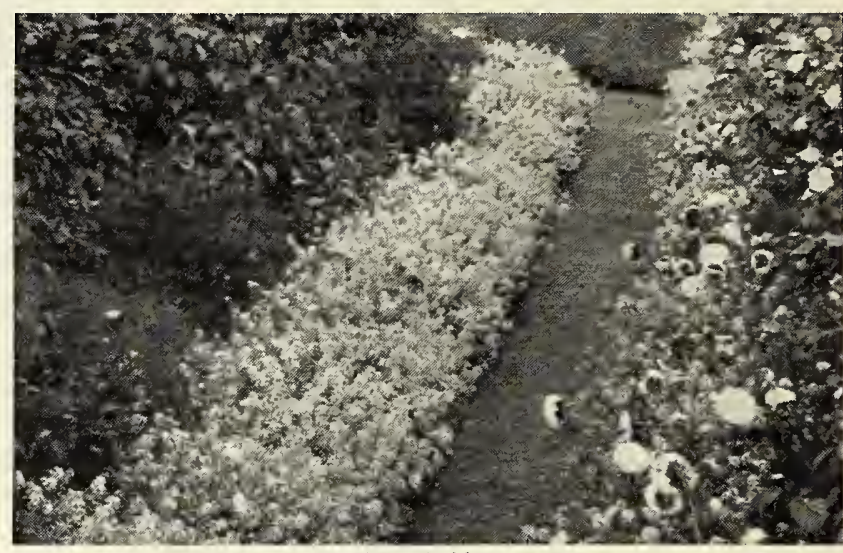

Border of Alyssum

\section{BELLIS (English Daisy)}

A favorite perennial, which will stand the winter if given the protection of a little litter. In bloom from early spring until well on in the summer. Easily raised from seed, which may be sown any time from spring until August. For best results, new plants should be raised from seed each year. The following are the finest doubleflowering kinds, selected after careful test. Pkt. Giant-fiowering White...................... 25

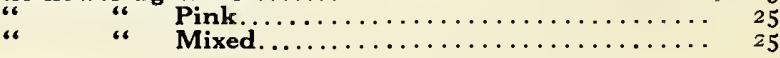

\section{COREOPSIS}

The Perennial Calliopsis is usually sown in June and transplanted I I/2 to 2 feet apart. Give slight winter covering. May be had in flower the first year if sown under glass in January.

Grandiflora. Deep golden yellow, cup-shaped flowers, on fine stems for cutting. Height 2 feet. All summer. Pkt. Io cts., 1/40z. $40 \mathrm{cts}$.

\section{CAMPANULA OR BLUEBELLS}

These are among our best-known hardy perennials. The tall varieties are fine for cutting, while the dwarf sorts make excellent border plants. All have dainty bell-shaped flowers. Some of the varieties offered will flower the first season from seed if sown early. Pyramidalis (Chimney Bellflower). Spikes 3 to 4 feet tall; erect, pyramidal Pkt. I/40z. flowers, large and of beautiful blue. Splendid for both garden and pot

culture.............................................. I

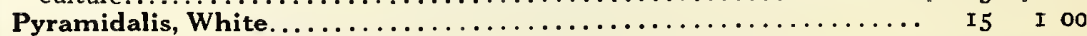

\section{CAMPANULA MEDIUM (Canterbury Bells)}

These are strictly biennials, and require to be sown from June I to September $I$; when strong enough, transplant to a distance of 6 inches apart; after frost has set in, protect with leaves and straw. They flower the following June, after which they die. Their colors are so pure that gorgeous effects can be achieved with them.

Double Mixed. Pkt. I5 cts., I/40z. $\$ \mathrm{I}$.

Single Mixed. Plkt. ro cts., $1 / 40 z$. 50 cts.

\section{GAMPANULA GAL YGANTHEMA (Cup-and-Saucer)}

These produce beautiful, large, single flowers resembling a cup and saucer; they require the same treatment as Campanula Medium. Pkt. $1 / 40 z$. quire the same treatment as Campanula Medium. Blue ............... \$o I5 \$I oo Striped............... I5 I oo

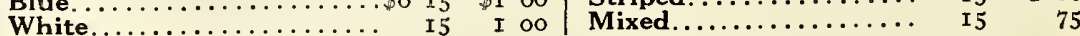

\section{PERENNIAL CANDYTUFT}

A very early-flowering variety, largely used in the hardy border. Foliage exceedingly pleasing in color and very decorative.

Gibraltarica. White, shaded pink. Pkt. I5 cts., oz. $\$ 3$. 

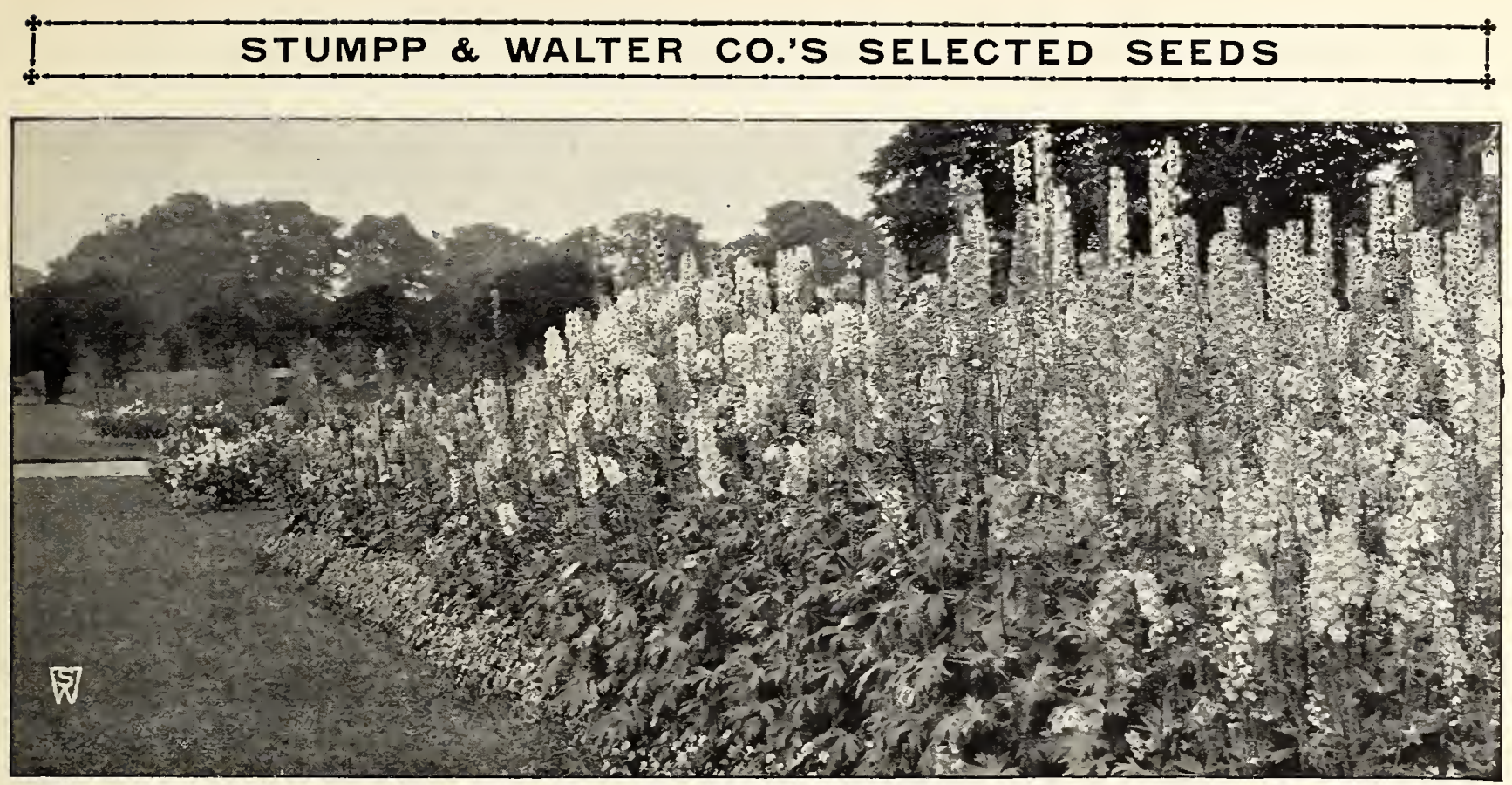

Delphinium (Gold Medal Hybrids)

\section{DELPHINIUM (Perennial Larkspur)}

There is, perhaps, no better known hardy plant than the Delphinium. The beautiful flowers, borne on tall, stately spikes, are a gorgeous sight and a charm to the garden. Sow seeds in early spring in shallow boxes indoors or in a hotbed. When seedlings are about $I$ inch high, transplant to flats 3 to 4 inches apart each way. About a week before planting out, remove to the open, taking care to protect them on cold days and nights; set out 6 inches apart in the garden. Plants treated thus usually flower the first season, during August. In the fall they may be lifted and set out in groups of colors, three or four plants at a distance of 3 feet a part, in the rear of hardy perennials, where they make a fitting background.

Gold Medal Hybrids. This splendid strain is of strong, vigorous habit, with immense spikes from 2 to 3 feet long, of large flowers mostly in fine shades of light blue. We doubt very much if this wonderful strain can be surpassed, and recommend that all our patrons desirous of obtaining some choice plants grow these hybrids. Pkt. 25 cts., 5 pkts. \$I, 1/80z. \$2.

Belladonna (Everblooming Hardy Larkspur). One of the finest and most continuous-blooming hardy Larkspurs. Clear turquoiseblue flowers, unequaled for delicacy and beauty. Pkt. 25 cts., 5 pkts. \$I, I/4OZ. \$I.5O.

Formosum. Large; tich dark blue, white center; borne on spikes 2 to 3 feet tall; one of the most popular varieties. Pkt. 25c., 1/80z. \$I.

\section{HARDY GARDEN PINKS}

These form low, bushy, tufted plants, above which are produced, on long stems, the beautiful fringed and fragrant flowers so valued in "old-fashioned" gardens. For permanent beds and borders these Pinks are unrivaled.

Plumarius, Double Mixed. Fringed, fragrant flowers of white, crimson, or purple shades, spotted and variegated.

Height, I foot.

Plumarius, Single Mixed. Large, fragrant flowers of beautiful colors and finely fringed.

Scotch, or Florists' Pinks. Excellent perennial garden plants, about I foot high when in bloom. They are vigorous, very hardy, and flower prof usely during spring and early summer. The flowers are very large, very double, beautifully fringed, and emit a grateful clover-like perfume. Mixed colors........

\section{GYPSOPHILA (Baby's Breath)}

Pretty, free-flowering, elegant plants, succeeding in any garden soil. Their misty white panicles of bloom are largely used for mixing with other cut-flowers.

Paniculata. White flowers; fine for bouquets; one of the favorite hardy perennials; blooms first year if sown early. 2 feet. Pkt. Io cts., $1 / 4 \mathrm{oz}$. $30 \mathrm{cts}$., Oz. $\$ \mathrm{I}$.

Paniculata f.-pl. The new double-flowering Baby's Breath, and one of the finest hardy plants for cutting. Pkt. $25 \mathrm{cts}$. I/80z. \$I.

\section{DIGITALIS (Foxglove)}

This ornamental hardy plant is used extensively for naturalizing in shrubbery borders and along the edges of woods. It grows well under almost all conditions, giving a wealth of bloom during June and July.

Gloxiniæflora. This is an improved strain of the ordinary Foxglove, $D$. purpurea, with handsome spotted Gloxinia-like flowers on Iong spikes.

Alba. White ground. Rosea. Rose ground. Mixed. Purpurea. Purple ground. Lutea. Yellow ground. Each, pkt. $10 \mathrm{cts}$., 1/40z. $50 \mathrm{cts}$.

Monstrosa (Mammoth Foxglove). Long spikes surmounted by one enormous flower; all colors mixed. Pkt. I5 cts., I/40z. \$I.

\section{GAILLARDIA (Blanket Flower)}

The perennial varieties of this family are grown in most hardy borders. They thrive in any position or soil, require little or no protection, and take care of themselves. If sown early, they begin flow-
ering in July, and continue to be a mass of bloom until cut down by frost; fine for cutting. Height, 2 feet.

S. \& W. Co.'s Hybrids. This strain of Hybrid Gaillardia has been obtained from a specialist who has developed a splendid type, covering only the best varieties. The flowers are as large as sunflowers. Pkt. 25 cts., I/80z. 75 cts.

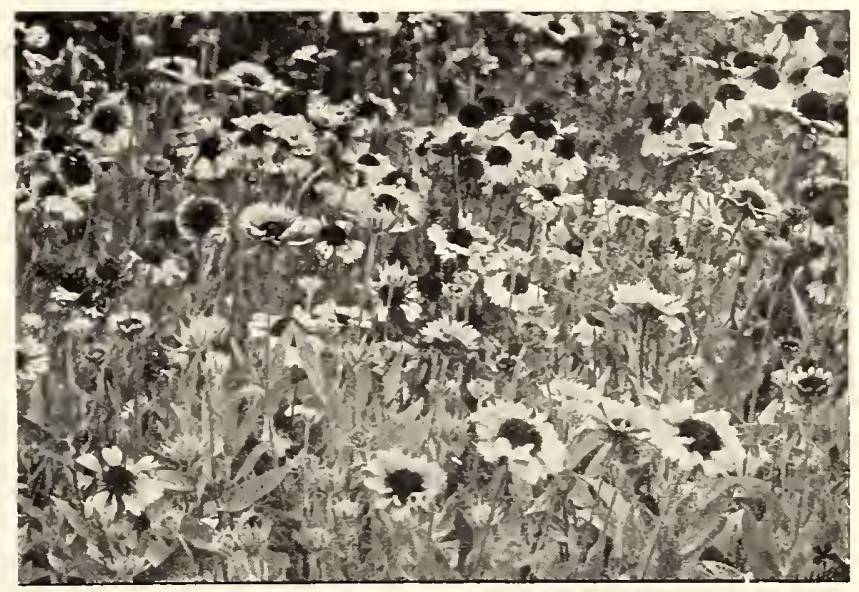

Gaillardia (S. \& W. Co.'s Hybrids) 


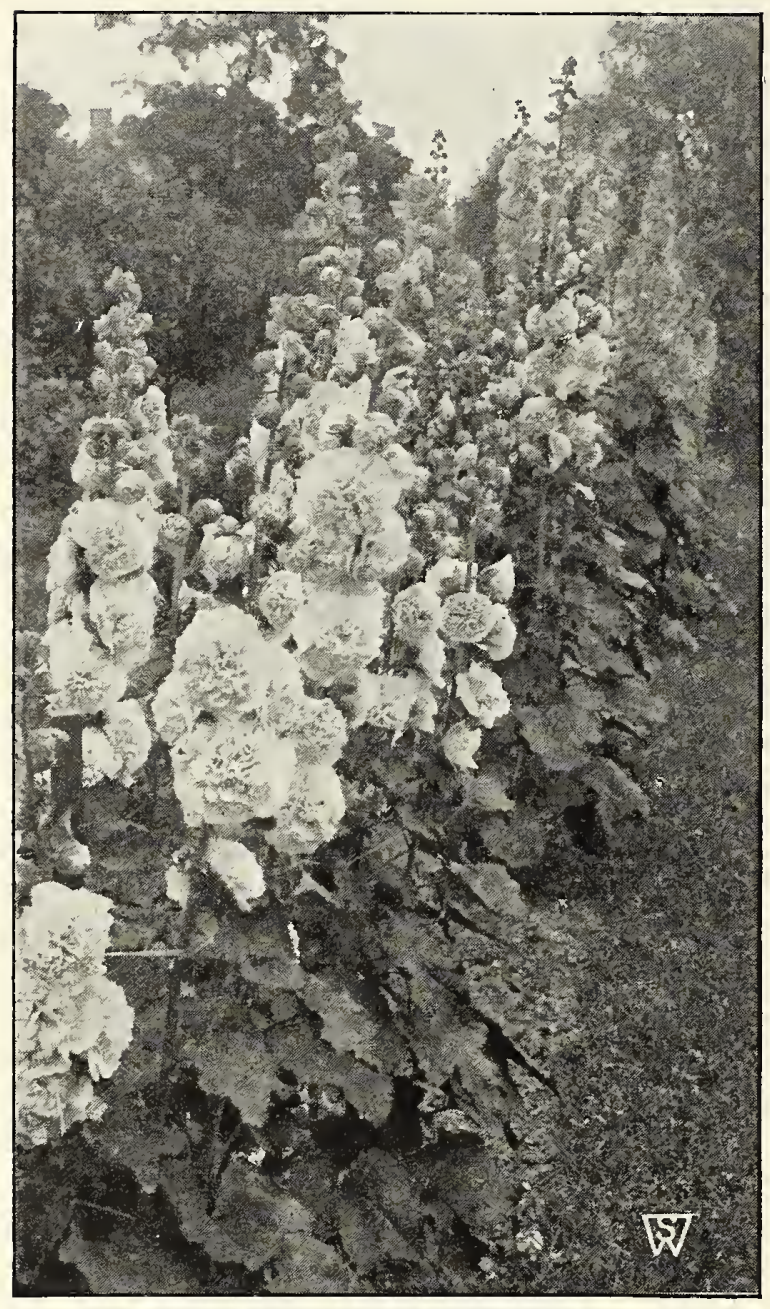

Chater's Superb Double Hollyhocks

\section{LATHYRUS}

Everlasting, or Hardy Sweet Pea

Hardy climbers, growing 6 to 8 feet high when trained on a trellis. The flowers are borne in large clusters. They are peculiarly adapted to rough places, to scramble over rocks and bushes; splendid cut-flower.

White. Pkt. Io cts.

Pkt. ro cts.

Mixed Colors. Pkt. Io cts.

\section{LUPINUS (Lupine)}

Polyphyllus, White

Polyphyllus, Blue

Polyphyllus, Mixed

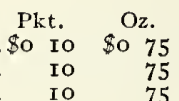

MYOSOTIS (Forget-me-not) See page 34

GIANT PANSIES. See page 36 HARDY PHLOX

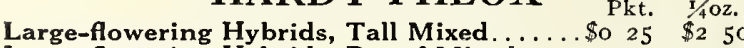
Large-flowering Hybrids, Dwarf Mixed......

\section{HOLLYHOCKS}

One of the most popular of hardy garden plants. The beautiful color effects produced by the planting of these flowers, combined with their dignified and stately appearance, render them indispensable for either the old-fashioned garden or the well-planned herbaceous border. As a background for other flowers or planting among shrubbery, they are without an equal. As the plants are affected with rust occasionally, we recommend frequent spraying in springtime with bordeaux mixture.

\section{Chater's Superb Double}

\begin{tabular}{|c|c|}
\hline $\begin{array}{l}\text { Chamois } \\
\text { Deep Rose } \\
\text { Maroon }\end{array}$ & $\begin{array}{l}\text { Newport Pink } \\
\text { Pure White } \\
\text { Salmon-Rose }\end{array}$ \\
\hline
\end{tabular}

S. \& W. CO.'S DOUBLE MIXED. This is an excellent strain. The selection has been made with great care from the strongest plants and brightest colors. Pkt. I 5 cts., 1/80z. 75 cts.

S. \& W. Co.'s Single Mixed. Pkt. Io cts., I/80z. 50 cts.

\section{HIBISCUS}

\section{Marshmallow}

Showy, ornamental plants, for mixed beds or shrubbery borders. Hardy perennial, but will bloom first year from seed if sown early.

Moscheutos. Light rosy red, with dark center. Pkt. Io cts.

Crimson Eye. Fine for borders and groups; color white, with crimson center; flowers very large. Pkt. Io cts.

Golden Bowl. Giant yellow, cup-shaped flowers, from 6 to 9 inches in diameter; of rich cream, with velvety maroon center. The plants commence to bloom early and continue until cut down by frost. Pkt. Io cts.

\section{PERENNIAL POPPIES}

Like the annual Poppies, these should be sown as early in the spring as the ground can be worked. The plants disappear during July and August, appearing again when the weather becomes cool. When this fall growth starts they should be transplanted to their permanent flowering quarters. It is well to mark the places they are planted, to insure the roots against disturbance during their annual resting period.

Orientale, Finest Mixed. Pkt. Io cts., 1/80z. \$I. Iceland, Finest Mixed. Pkt. I 5 cts., $1 / 4 \mathrm{Oz} .75 \mathrm{cts}$.

\section{HARDY PRIMROSES}

These are among the best of the early spring-blooming plants. With a slight protection they will stand the winter, but will do better if protected by a coldframe.

Vulgaris (English Primrose). Canary-yellow; fragrant. Pkt. I5 cts.

\section{PYRETHRUM}

S. \& W. Co.'s Single Hybrids. Our strain of this beautiful hardy perennial has been grown specially in England for us by a specialist of this flower. The cosmos-like flowers range in color from the palest pinks to deep red, the bright yellow centers forming a splendid contrast. Blooming as they do during May and June and again in the fall, and on account of their longlasting quality and utility as a cut-flower, we recommend them highly to our patrons. Pkt. 25 cts., 5 pkts. \$I.

S. \& W. Co.'s Double Hybrids. Colors and character of plants similar to the above, except that centers are tufted, somewhat resembling a double China aster. Pkt. 25 cts., 5 pkts. $\$$ I.

\section{SWEET WILLIAM Dianthus barbatus}

A weil-known, attractive biennial which flowers the second season from seed. Sow outdoors in May, and transplant in August.

Double Finest Mixed. Pkt. Io cts., 1/4Oz. \$I.

Single Finest Mixed. Pkt. Io cts., $1 / 40 \mathrm{oz}, 50 \mathrm{cts}$

Newport Pink. A distinct new color which originated in one of the farfamed gardens at Newport, R. I. In color it is what florists call watermelon-pink or salmon-rose; strikingly brilliant and beautiful. The flowers are borne in massive heads, on stems 18 inches high. For midseason mass bedding it has no equal. It is also very effective for cutting. Pkt. I $5 \mathrm{cts}$., 2 pkts. $25 \mathrm{cts}$. 


\section{NEW AND RARE EXHIBITION DAHLIAS}

We have listed below our selection of a choice list of varieties of garden Dahlias, some of which were listed under our new and rare varieties of previous years and which on account of larger stocks may be obtained at more moderate prices.

Ambassador. (Hybrid Cactus.) Its color is, perhaps, best described as a soft yellow at the center, with salmon, amber, and pink shadings, gradually deepening toward the tips. The flowers are of largest size and are set just right on perfect stems. A strong grower and free bloomer. \$I each, \$Io per doz.

Ellinor Vanderveer. (Decorative.) A splendid exhibition Dahlia with large, satiny rose-pink blooms of great depth and substance on fine long, strong stems. \$I.50 each, \$ I5 per doz.

Jersey's Beacon. (Decorative.) Very large blooms of Chinese scarlet, paler on the reverse, giving a twotoned effect. A great favorite and a real "beacon of the garden." Free bloomer and vigorous grower. \$I.5O each, \$I 5 per doz.

Jersey's Beauty. (Decorative.) This is, without doubt, the finest true pink Decorative Dahlia yet introduced. Owing to a good supply of tubers, we are able to offer this fine Dahlia at a reasonable price this year. $75 \mathrm{cts}$. each, $\$ 7.50$ per doz.

Mrs. John T. Scheepers. (Decorative.) Very large flower, standing well above the foliage on long, upright stems. The color is best described as a canary-yellow, shading to delicate pink on outer petals. Strong, vigorous, free-blooming variety. $75 \mathrm{cts}$. each, $\$ 7.50$ per doz.

Oyster Bay Beauty. (Decorative.) Large, dark glowing velvety red blooms of lovely shape on very fine stems, admired by all. Profuse bloomer. Fine in combination with autumn shades. $\$ 2.50$ each, $\$ 25$ per doz.

Robert Treat. (Decorative.) Flowers 9 to i I inches across and 4 inches deep, of a pleasing American Beauty rose-color, unlike any existing variety. Strong. healthy grower and free bloomer. A sensational Dahlia. \$I each, \$ro per doz.

Sagamore. (Decorative.) Exceptionally fine cutflower of light apricot-buff, shaded orange toward center. Fine strong stems; excellent keeper. \$I.5O each, \$I 5 per doz.

Trentonian. (Decorative.) Very large blooms of an exceptionally appealing shade - a fine blending of oldgold, amber, and coppery bronze, the whole forming a flower of great brilliancy, with a reddish bronze center. Long, strong stems. \$I each, \$Io per doz.

Viola Phillips. (Hybrid Cactus.) Salmon suffused with mauve; very lovely combination; admired by all. Giant flowers on strong stems. This splendid Dahlia should be in every garden. $75 \mathrm{cts}$. each, $\$ 7.50$ per doz.

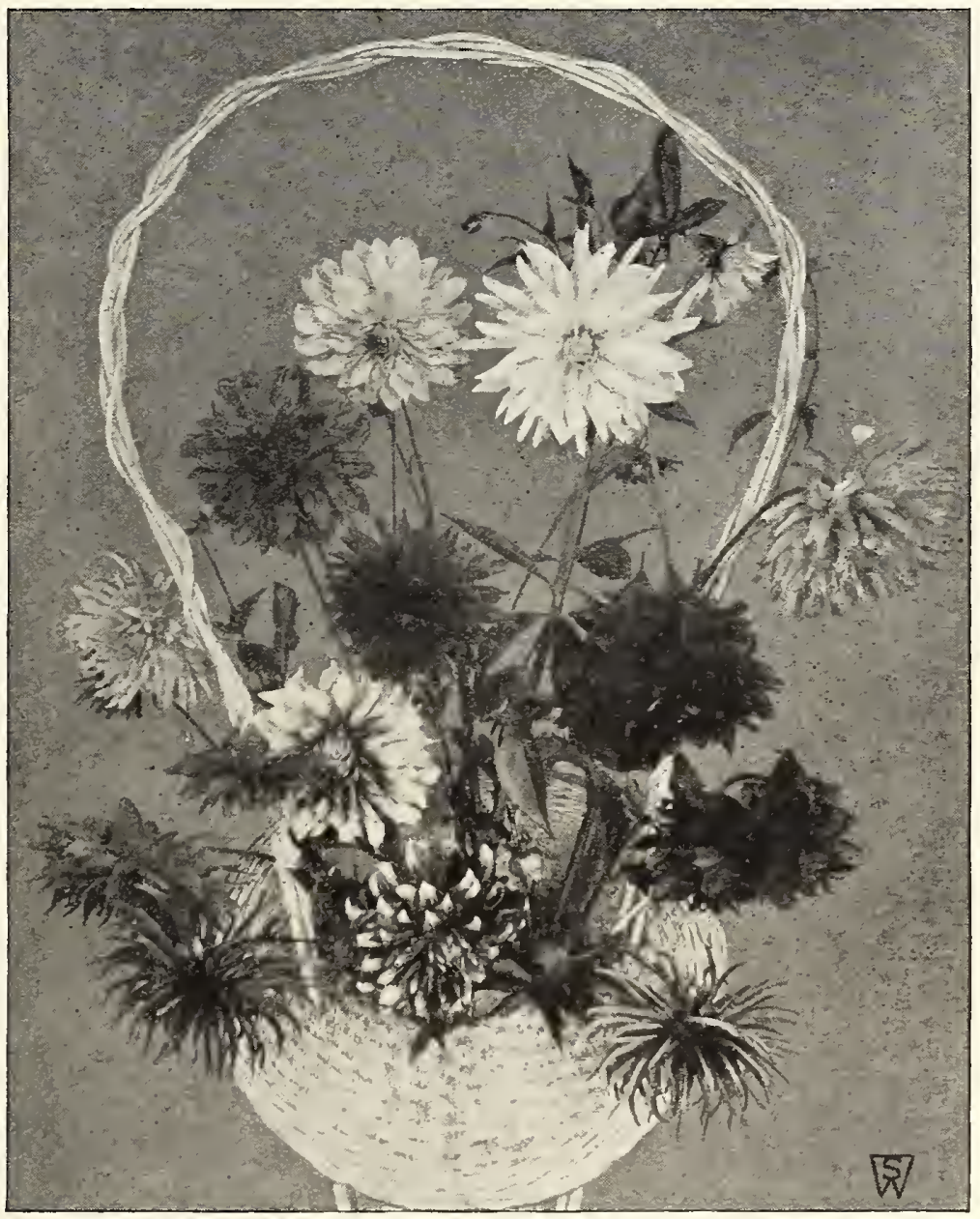

Splendid decorative effects can be obtained by using various types of Dahlias as illustrated above

\section{PEONY-FLOWERED}

This splendid type of Dahlias, which originated in Holland, is now quite popular. The artistic flowers are very large and are perhaps best compared in form to the semi-double peonies. They all flower very freely and are borne on long, strong stems, making excellent material for cutting as well as for garden decoration. We offer a select list of standard varieties.

Diermant van Bijstein. A variety imported from Holland, and one we can highly recommend. It is a very distinct and new shadelilac-blue throughout. The plants are tall and sturdy growers, holding the blooms well above the foliage. $50 \mathrm{cts}$. each, \$5 per doz.

Louise Schwartz. Very large, beautiful creamy salmon bloom shading to delicate pink, borne on strong stems. Free bloomer. 50 cts. each, \$5 per doz.

Radin Kartini. A very free-blooming variety with large salmon flowers shaded with lilac and mauve. Strong stems. 50 cts. each, $\$ 5$ per doz.

\section{STANDARD DECORATIVE}

The following varieties are a very select list of good Decorative Dahlias for garden culture. They are all free bloomers and excellent for cutting.

Amun Ra. Flat blooms with rounded petals of unusual color, coppery bronze shading to gold and amber, carried royally on long, sturdy stems. 5o cts. each, $\$ 5$ per doz.

Patrick O'Mara. A good keeping Dahlia of an unusually soft and pleasing shade of orange-buff, slightly tinged Paul Neyron-rose. 50 cts. each, $\$ 5$ per doz.

Pride of California. (Giant Decorative.) The flowers are of large size, perfect in form, and of a glowing cardinal-red. The finest of the dark rich crimson decorative Dahlias for all purposes. 50 cts., each, $\$ 5$ per doz.

Snowdrift. One of the finest white Decorative Dahlias. Enormous flowers of perfect form, with broad, waxy white petals, borne on long, stiff stems, held erect. 5o cts. each, \$5 per doz. for large exhibition looms. Price \$r.5o. 


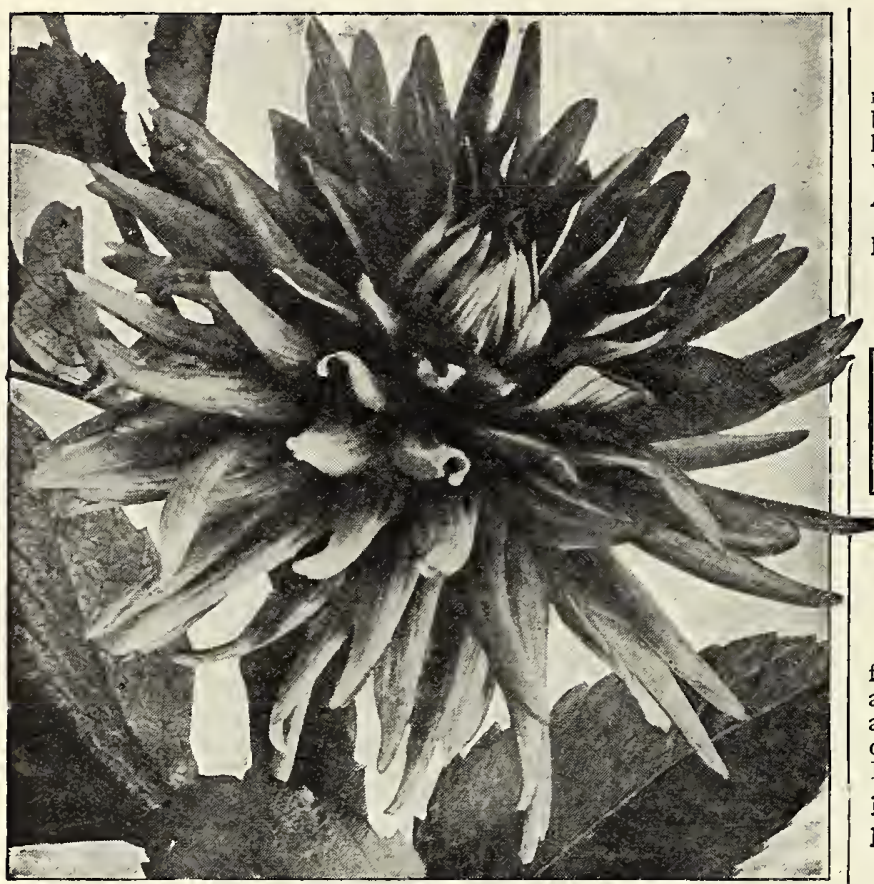

Cactus Dahlia, Countess of Lonsdale

\section{SELECT CACTUS DAHLIAS}

This is a selection made with a view to supplying the amateur with an assortment of Cactus Dahlias which may be depended upon for an early and continuous display in the garden and at the same time an abundance of flowers for cutting. We offer strong tubers of the following:

Countess of Lonsdale. If only one Cactus Dahlia could be had, ninety-nine people out of a hundred would select this one. A deep salmon-red in color. $35 \mathrm{cts}$. each, $\$ 3.5^{\circ}$ per doz.

F. W. Fellowes. The flowers are of unusual size for the long, narrowpetaled type, of which this is one of the finest examples. In color it is an intense coral-red with deeper suffusion toward the center. A leader in this type at all Dahlia exhibitions or for the garden. Excellent as a cut-flower. $75 \mathrm{cts}$. each, $\$ 7.50$ per doz.

Kalif. This is a truly majestic flower, frequently measuring over 9 inches in diameter. The flower is of perfect Hybrid Cactus form, and in color a beautiful pure deep glowing scarlet. $50 \mathrm{cts}$. each. $\$ 5$ per doz.

\section{POMPON DAHLIAS}

We offer below a select list of these beautiful Pompon Dahlias, a miniature form of the Show Dahlias, having the same ball-like form. but much smaller in size. The plants are also smaller, of branching habit, and produce an endless profusion of flowers, which are invaluable for table decoration and boutonnieres.

Amber Queen. Rich amber, Hedwig Pollwig. Maroon with shaded apricot.

Bobby. Plum-color.

white blotches.

Kleine Domitea. Bronze.

Price, any of the abpve, $30 \mathrm{cts}$. each, $\$ 3$ per doz.

\section{DAHLIAS UNDER COLOR Pink Red}

25 cts. each, $\$ 2.50$ per doz.

\section{CALADIUM ESCULENTUM \\ Elephant's Ear}

One of the most effective plants in cultivation for beds, borders, or for planting out upon the lawn. Very frequently used as border plants about surburban residences, where their large, rich green leaves afford an excellent embellishment when contrasted with the colors of the dwellings. Leaves often measure 3 to 4 feet long and $21 / 2$ feet wide. Bulbs do best if planted outdoors in this latitude about June $I$.

First-size Bulbs. I5 cts. each, $\$$ I.50 per doz., $\$$ Io per Ioo.

Mammoth-size Bulbs. 20 cts. each, $\$ 2$ per doz., $\$ I_{5}$ per Ioo.

\section{MADEIRA VINE \\ Climbing Mignonette}

A beautiful and popular vine, covering a large space in a short time. Fleshy heart-shaped leaves of a light green, and numerous racemes of feathery flowers of delightful fragrance. Protect with litter in this latitude. I5 cts. each, \$I.50 per doz., \$Io per IOO; by mail, I5 cts. per doz. extra.

\section{CINNAMON VINE \\ Dioscorea Batatas}

A beautiful, rapid-growing summer climber, with bright green, glossy foliage, and spikes of deliciously cinnamon-scented, white flowers. It is perfectly hardy, the stem dying down in winter, but growing with great rapidity in the spring, so as to cover any trellís or arbor very early in the season. Large, select roots, I $5 \mathrm{cts}$. each, $\$$ I.25 per doz., \$9 per Ioo. Mammoth roots, 25 cts. each, \$2.50 per doz., \$I5 per Ioo.

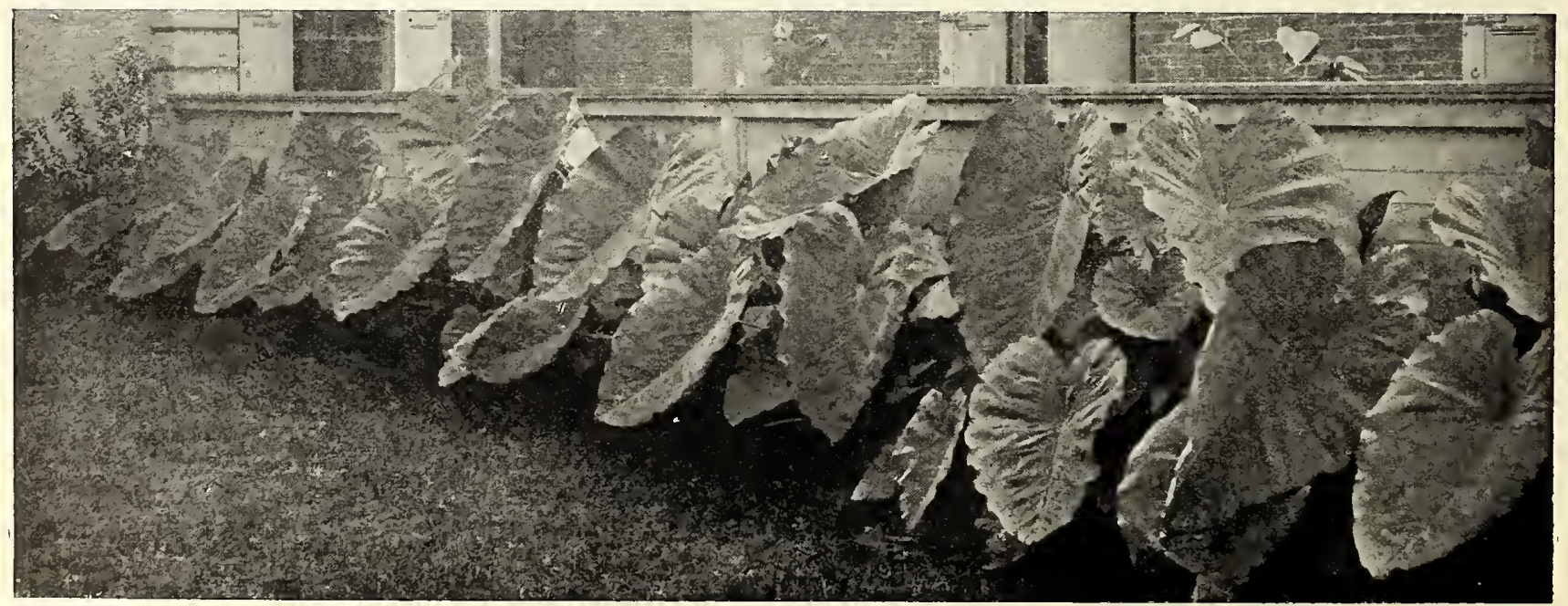




\section{Everybody's Flowers Because Everybody Can Grow Them}

Culture.-Any good garden soil will grow Gladiolus well, provided they are planted in a sunny location. Bulbs should be planted 4 inches deep and at least 6 inches apart; frequent cultivation with a hoe or weeder, around the base of the plant, to prevent the soil from becoming hard or cakey, is advisable. Where desired for garden decoration or exhibition, we advise plants being staked after attaining the height of I foot. (We offer light green dyed bamboo canes, which are excellent for this purpose.) Water copiously, and as the flowerbuds begin to form, apply liquid manure for the best results.

America. Delicate lavender-pink flowers of large size, borne on strong stems, and well placed; splendid habit. Very popular cut-flower variety. Io cts. each, $75 \mathrm{cts}$. per doz., $\$ 5$ per Ioo.

Anna Eberius. Dark velvety purple, throat deeper shade; very large flowers on tall, fine spikes. A very fine variety in an unusual color. I5 cts. each, \$I.25 per doz., \$8 per Ioo.

Crimson Glow. Deep, brilliant crimson, overlaid with darker shades; lower petals blotched with deep velvety crimson. The flowers are immense and plentifully spread on the tall, graceful stem. A very striking variety with a very vigorous constitution. I5 cts. each, \$1.25 per doz., \$8 per Ioo.

Gretchen Zang. A beautiful rose tone of pink, blending toward scarlet on the lower petals. A variety of great merit on account of its splendid substance and size. I5 cts. each, \$1.25 per doz., \$8 per Ioo.

Halley. A variety that is largely grown on account of its earliness. The flowers are large in size, of beautiful salmon-pink, with creamy white blotch in throat. One of the earliest-blooming varieties in our list. Io cts. each, 75 cts. per doz., $\$ 5$ per Ioo.

Herada. Blooms of immense size on tall, straight spikes. The large blooms are pure mauve, glistening and clean, with deeper markings in the throat. I5 cts. each, \$I.5O per doz., \$Io per Ioo.

Mary Fennel. A beautiful shade of deep lavender, with petals penciled primrose. Flowers are large in size, borne on spikes medium in height. An excellent variety for contrasting with pale pink and primrose sorts. $20 \mathrm{cts}$. each, \$2 per doz., \$I 5 per Ioo.

Mary Pickford. An extraordinary flower and spike of a most delicate creamy white. Throat finest soft sulphur-yellow; stem and calyx also white. I5 cts. each, \$I.50 per doz., \$Io per Ioo.

Mrs. Francis King. Brilliant flamingo-pink, blazed with vermilionred. Popular variety on account of its attractive color. Splendid for mass effects. Flowers are large in size, well placed on strong, tall spikes. Io cts. each, 75 cts. per doz., $\$ 5$ per Ioo.

Mrs. Frank Pendleton. Salmon-pink which extends to reverse side of the petals as well as in the center, with a rich, deep maroon blotch on the three lower petals. Flowers are wide open and well placed on strong spikes. A variety that has become very popular since its introduction some years ago and now can be obtained at a more moderate price. Io cts. each, 75 cts. per doz., $\$ 5$ per Ioo.

Mrs. Dr. Norton. Delicate cream and pink, deepening towards the edges; sulphur-yellow center. Flowers widely expanded. A very beautiful variety and much admired at Gladiolus exhibitions. I 5 cts. each, \$I.50 per doz., \$Io per Ioo.

Niagara. Soft primrose, faint lines of lilac in the throat, with purple stamens and pale carmine stigmas which add to the attractiveness of the variety. Flowers are large in size, borne on tall spikes. I5 cts. each, \$I.25 per doz., \$8 per Ioo.

Orange Glory. This beautiful new ruffled Glory has all the refined qualities of the original variety, Glory. The color is a splendid shade of rosy orange. The flowers are exquisitely ruffled and are well placed on strong stiff stems. I5 cts. each, \$I.5O per doz., \$IO per IOO.

Panama. Similar in type to America, but of a deeper shade of pure rosepink. The flowers are large in size and well placed on tall, strong spikes. Io cts. each, 75 cts. per doz., $\$ 5$ per Ioo.

Peace. Few varieties have become as popular as Peace. The general effect of the flower is white, with a pale lilac feathering on the interior petals. They are large in size, well placed, and are borne on tall, strong spikes. Io cts. each, 75 cts. per doz., $\$ 5$ per Ioo.

Schwaben. Pure canary-yellow, with a carmine blotch deep in the throat which aids in detracting from its uniformity in color. Flowers are wide open, large in size and well placed on strong spikes of medium height. Io cts. each, \$I per doz., \$6 per Ioo.

War. (Originator's stock.) The finest of its color yet introduced. Flowers often measure 7 inches across, of a deep ox-blood-red, shaded crimson-black. The flowers are well placed on spikes frequently attaining a height of 5 to 6 feet. The foliage is broad, deep green, almost as heavy as an iris leaf. A wonderful variety that can now be had at a reasonable price. I5 cts. each, \$I.50 per doz., \$Io per Ioo. 


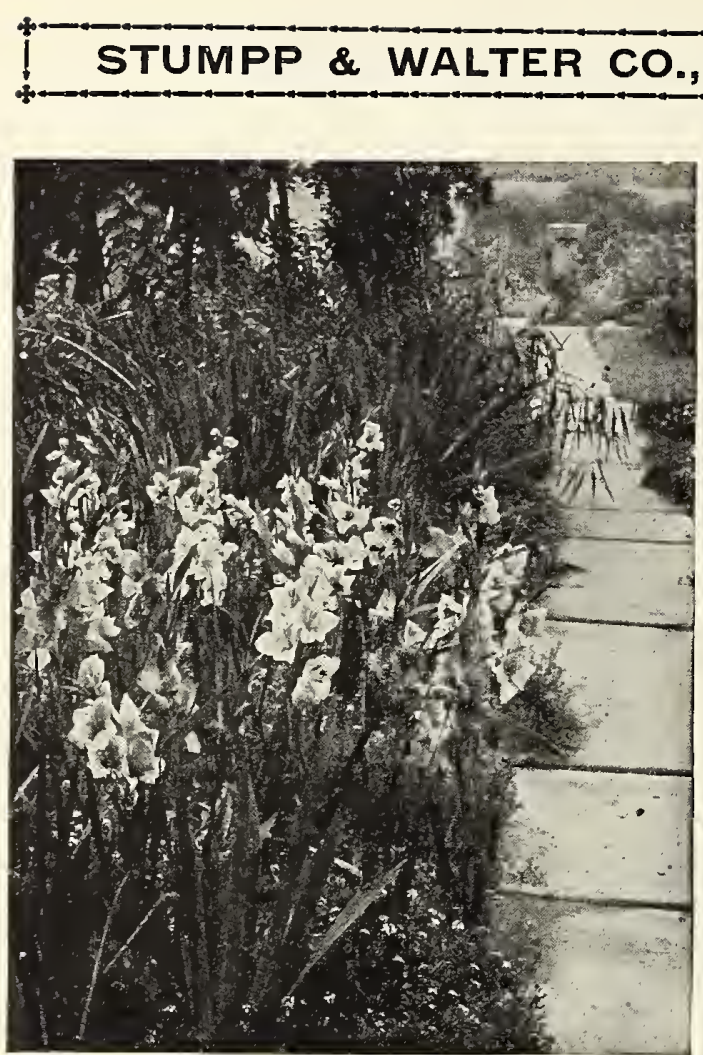

Gladioli are excellent for the garden border

\section{S. \& W. Co.'s Famous Gladioli in Mixtures}

\section{S. \& W. CO.'S MIXTURE OF AMERICAN HYBRIDS}

In preparing this mixture of Gladioli, some surplus named sorts, we have endeavored to cover all the conceivable colors that can be obtained in this beautiful family of flowers. The mixture is prepared from the finest named as well as seedling sorts, and has with it a popular price so as to encourage the liberal planting of them. The varieties used in the mixture are varieties of matured good growers and are excellent for cut-flower purposes or for planting in mixed borders, and we offer them at $60 \mathrm{c}$. per doz., $\$ 4$ per I00, $\$ 38$ per I, 000 .

\section{S. \& W. CO.'S NEW PRIMULINUS HYBRIDS}

When the original Primulinus was first grown in this country, many Gladiolus-growers were impressed with the graceful habit of the plant and flowers. They were small and somewhat hooded. The original species, as they were first introduced from South Africa, created interest among these growers mainly for their habit and the beautiful colorings of the flowers. They proceeded to cross them with the finest of the large-flowering Gladioli and the resultant crosses brought forth a really beautiful acquisition. The flowers were larger, more open, retaining their graceful placement on the spikes and also their beautiful range of artistic colors. Our hybrids range in color from pale sulphur-yellow-apricot to the deepest chrome-yellow and excellent shades of orange as well. We are pleased to offer this splendid mixture and suggest that our patrons try some, as for artistic decorations these flowers borne on long slender spikes are wonderful. $75 \mathrm{cts}$. per doz., $\$ 5$ per IO0, $\$ 45$ per I, 000 .

\section{CHOICE GANNAS ( $\left(\begin{array}{c}\text { DORMANT } \\ \text { ROOTS }\end{array}\right)$}

The wonderful size of flowers, depth of coloring, and graceful habit of plants in the modern Canna have greatly increased its usefulness to the garden-lover. It is much to be regretted that we occasionally observe mass plantings at railroad terminals and at some of our public institutions of the old Indian Shot. The modern Cannas we offer on this page are so far superior in every way that we feel certain that in a few years they will not only be used extensively for mass planting in beds, but will also be used in hardy borders, particularly for their foliage and color effect.

Dormant roots of Cannas should be potted in 4- or 5 -inch pots or planted in shallow boxes in March or April, and kept in a warm place to start them into growth. The started plants may be planted out about May Io to June I in the vicinity of Baltimore; earlier in the South and later in the North. They should be set about 2 feet apart.

\section{Six Good Standard Varieties}

Eureka. Canna hybridizers have worked patiently ever since the time of the introduction of the modern Canna, which bears such little relation as regards beauty of foliage and size of flowers to the old Indian Shot of bygone days, to produce a pure white. In offering Eureka we feel that our patrons will be using the best allround white variety for general mass planting or bedding. Height 4 feet.

Louisiana. An orchid-flowering variety of vivid scarlet. The long, silky flowers are borne well above the foliage. The beautiful bronze foliage contrasts well with the vivid color of the flower. Height 6 feet.

Hungaria. The ideal pink bedder. Flowers large, in good trusses; color not unlike that of Paul Neyron rose. One of the best of the newer introductions and without a doubt one of the finest pink bedding Cannas as yet introduced. Height $3 \frac{1}{2}$ feet.

King Humbert. Of superlative beauty and by far the finest of all bronze-leaved Cannas. The enormous trusses are made up of flowers that measure 6 inches across, and are a rich salmon-scarlet, distinctly and numerously flecked with deep crimson markings. It is a free bloomer, and with its rich, coppery bronze, massive

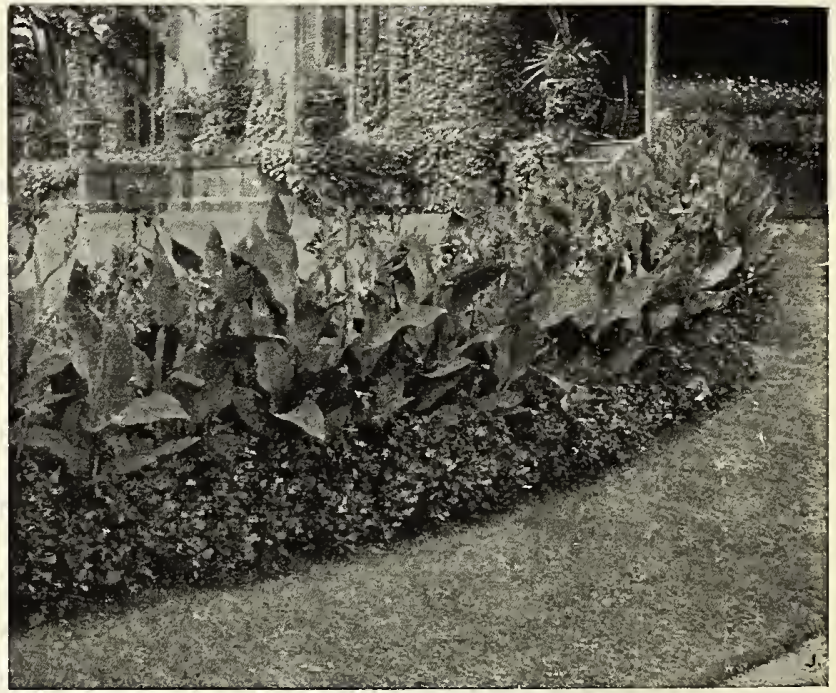

Border of Cannas foliage, it produces an effect both bold and striking. Height 5 feet.

Richard Wallace. While this variety is not new, it still remains among the best of the canary-yellow sorts. The habit of the plant is excellent. The flowers are very large and are borne gracefully above the foliage. Height $41 / 2$ feet.

Yellow King Humbert. A sport of that most popular of all Cannas, King Humbert, producing large and most beautiful shades of yellow, lightly spotted red, with green foliage, five or six clusters of flowers at a time. Height 5 feet.

Choice Roots of any of the above varieties, $20 \mathrm{cts}$. each, $\$ 2$ per doz.

COLLECTION: One each of the 6 varieties, $\$ 1$ 


\section{Lilium auratum}

\section{Golden-rayed Lily of Japan}

The flowers are pure white, thickly studded with crimson spots, while through the center of each petal runs a clear golden band. Fully expanded, the flowers measure nearly a foot across, are produced abundantly from July to September, and possess a most delicious fragrance. 3 to 5 feet. 9-in. to I I-in. bulbs........ Each $45 \quad \begin{array}{llll}\text { Doz. } & \text { I0o } \\ \$ 40 & \$ 35 \text { oo }\end{array}$

\section{Lilium speciosum magnificum}

\section{Oriental Orchids}

Words cannot describe the beauty of this variety. Frosted white, spotted, clouded and bordered with deep pinkish crimson. A much superior variety to the Roseum, Rubrum or Melpomene of the Speciosum type. For the border, among hardy plants or naturalized among rhododendrons, this is an equal favorite with the handsome Lilium auratum offered above. Splendid for pot culture as well. Blooms outside during August. Each Doz. 100 9-in. to II-in. bulbs........ \$o 45 $\$ 450 \quad \$ 35$ oo

\section{Lilium speciosum album}

The White Speciosum, which is usually grown with Magnificum and Lilium auralum, is a very dainty Lily. It flowers outside in the border or among rhododendrons at the same time as Auratum and Magnificum, and is one of the most extensively cultivated varieties.

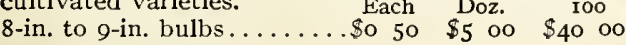

\section{Lilium Krameri}

This beautiful funnel-shaped Lily bears blooms 6 inches or more in length and frequently 5 inches across, and is a beautiful clear pink, shaded blush. The flowers are carried on strong stems 3 to 4 feet high. As this Lily roots from the stem as well as

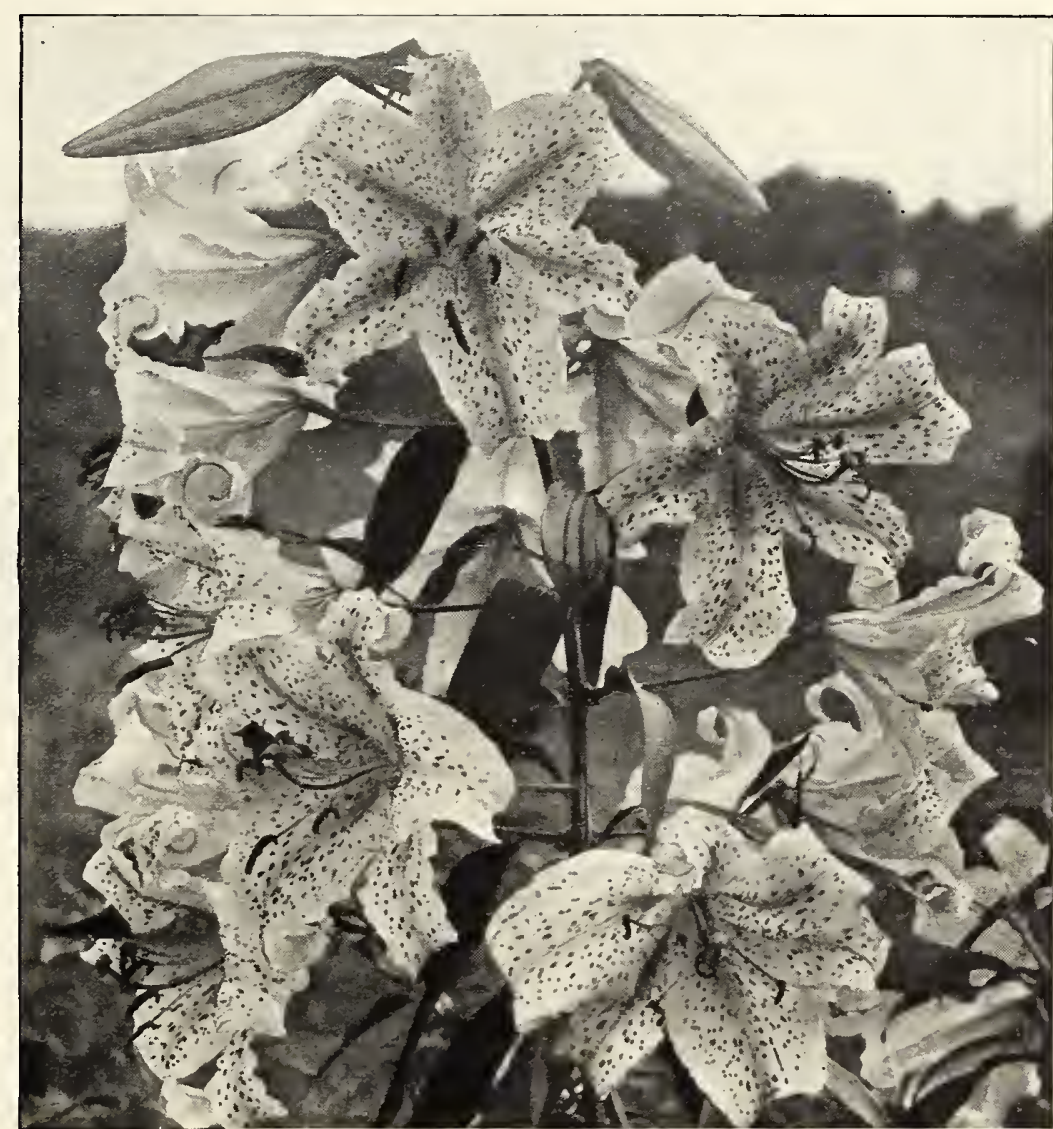

Lilium auratum (Golden-rayed Lily of Japan)

from the base of the bulb, it is advisable to cover it at least 6 inches. Best results are obtained by planting this Lily in early spring. Its blooming period is late June and early July. $50 \mathrm{cts}$. each, $\$ 5$ per doz., $\$ 40$ per roo.

\section{TUBEROSES}

One of the most delightfully fragrant and beautiful of the summerflowering bulbs. By skillful management a succession of flowers may be obtained all the year round. For early flowers they can be started in February or March in the greenhouse or hotbed; and for a succession they can be planted at intervals as late as July. For flowering in the open border, plant about the middle of May, or as soon as the ground becomes warm. We accept orders to be booked for fall delivery from our patrons who wish to grow bulbs in their greenhouses during the winter months.

Excelsior Double Pearl. We offer two sizes of this popular bulbous plant. First Size Selected Bulbs, Io cts. each, \$I per doz., $\$ 6$ per I oo; Jumbo Bulbs, $20 \mathrm{cts}$. each, $\$ 2$ per doz., $\$ 15$ per Ioo.

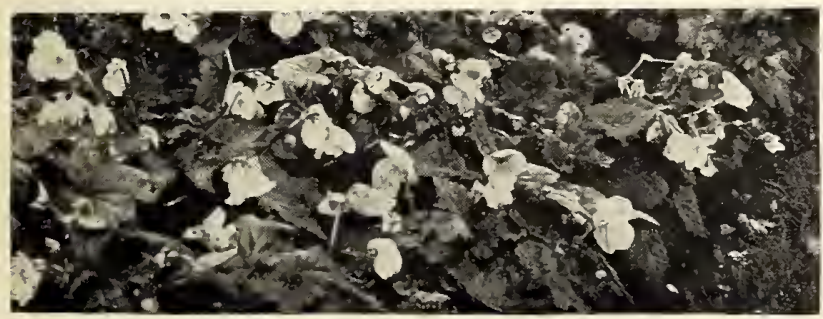

Tuberous-rooted Begonias

\section{BEGONIAS TUBEROUS-ROOTED}

A popular method of culture adopted by most amateurs is to provide a pan or box, and cover bottom surface to the depth of say one inch or two with sphagnum moss, placing the bulb immediately on top and then covering with still another layer of sphagnum moss. They should be kept moist and moderately warm. Plant in pots in a light but finely sifted soil, about one inch below the surface, and water cautiously until plant has shown considerable growth, then increase the amount. Good drainage is essential. A finely developed plant might consist of three bulbs planted in a 7 -inch pot.

\section{Single-Flowering Varieties}

White Yellow Pink Scarlet

30 cts. each, $\$ 3$ per doz., $\$ 20$ per 100 . Select mixture of all sorts, equal proportions, $25 \mathrm{cts}$. each, $\$ 2.50$ per doz., $\$ 17.50$ per 100

\section{Double-Flowering Varieties}

White Yellow Pink Scarlet

$30 \mathrm{cts}$. each, $\$ 3$ per doz., $\$ 20$ per 100 . Select mixture of all sorts, equal proportions, 25 cts. each, $\$ 2.50$ per doz., $\$ 17.50$ per 100 


\section{HYBRID TEA ROSES}

Our Roses are all American-grown, two-year-old stock. They are budded or grafted, and while some planters prefer stock grown on their own roots on account of the liability of budded plants to throw up suckers, this will rarely occur if deep plantings are made, and if a wild shoot should appear, it is readily distinguished by the most casual observer, and should be removed close to the root. Budded plants are more vigorous, produce finer blooms, come to bearing sooner, and are equally as permanent and hardy as those on their own roots, and many of the choicest varieties do not succeed unless budded or grafted.

Culture and Hints on Growing. The best soil to grow Roses is good top soil with rotted cow manure added. Dig out the bed to a depth of 2 feet or more, and, if drainage is imperfect, it must be provided for. Fill in with a mixture of soil and manure as above. It is best to make beds, if possible, in advance of planting, so as to allow time for settling. Beds may be made any size, but it is best to have them about $3 \frac{1}{2}$ by 5 feet, which enables you to pick the blooms without stepping on the beds. The ideal time to plant is just after severe frost has passed. Hybrid Teas should be set I 8 inches apart; Hybrid Perpetuals 2 feet apart, and both 8 inches from the edge of the beds. They should be planted with the roots well spread out and placed about 9 inches below the surface of the ground, the soil made firm about them and liberally watered. Throughout the summer the surface soil should be cultivated weekly. If good cultivation, like the above, is given, watering will rarely be necessary. The most serious insect pest that attacks Roses is the rose-bug.

Winter Protection. In this latitude the most satisfactory form of protection is to draw up a mound of soil from 8 to to inches high around the base of the plant, then cover the entire bed after the ground begins to freeze with any loose material, such as strawy manure, evergreen boughs, or corn stalks.

\section{POT-GROWN PLANTS}

COLUMBIA. This beautiful Rose has not only become one of the most popular greenhouse blooming varieties, but has proved itself one of the best bedding and garden sorts. It is of strong, vigorous habit and exceptionally free-blooming. In color it is a most pleasing shade of rose-pink and delightfully fragrant.

DUCHESS OF WELLINGTON. Fairly full flowers with petals of great substance. As they develop they change from saffron-yellow to deep coppery saffron-yellow. Very free-flowering and fragrant.

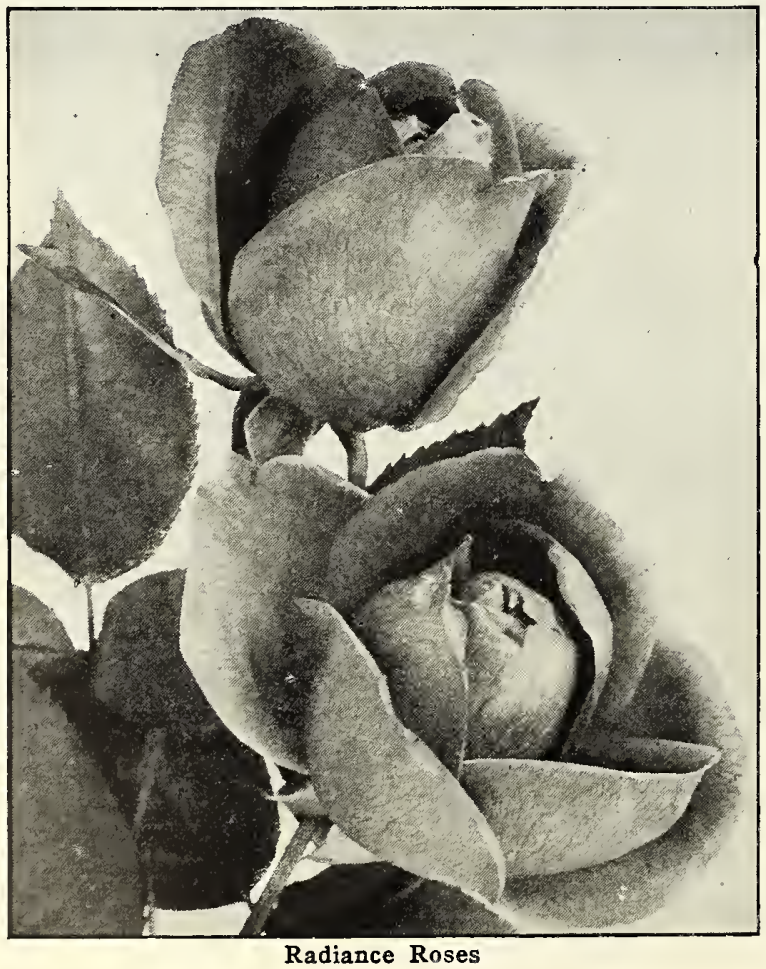

GRUSS AN TEPLITZ. Of a rich scarlet, shading to a velvety crimson. A very free grower and in bloom all the time; succeeds well under the most ordinary conditions.

HADLEY. Considered by many as being one of the best garden varieties of its color - a rich crimson, varying to deep velvety crimson. The flowers are well formed and very fragrant.

KAISERIN AUGUSTE VIKTORIA. A soft pearly white, faintly tinted lemon in the center. Very fragrant, beautifully formed flowers on long, graceful stems.

I.OS ANGELES. We give the originator's description, and heartily endorse it: "One of the finest Roses ever introduced. The growth is very vigorous and produces a continuous succession of longstemmed flowers of luminous flame-pink, toned with coral and shaded with translucent gold at the base of the petals. In richness of fragrance it equals in intensity the finest Marechal Niel. The buds are long and pointed, and expand into a large flower; the color is maintained from the bud until the last petal drops."

MISS LOLITA ARMOUR. One of the newer Roses with large flowers of deep, coral-red with a golden coppery red suffusion, the base rich golden yellow with coppery red sheen.

MME. CAROLINE TESTOUT. Large, globular flowers of bright satiny rose, with deeper center. Very free and fragrant, and one of the most popular and valuable bedding varieties.

MME EDOUARD HERRIOT. The buds are coral-red in color, shaded with yellow at the base; the medium-sized open flowers, medium double, are coral-red, shaded yellow and bright rosy scarlet, passing to shrimp-red.

MRS. AARON WARD. Full, double flowers of lovely form, equally attractive in bud and bloom. They are a distinct Indian yellow shading lighter toward the edges, and under certain weather conditions the entire flower will sometimes come a yellow tinted white, but it is always beautiful.

OPHELIA. The flowers are erect on long, stiff stems, of perfect form, large size, and of a most pleasing delicate tint of salmon-flesh, shaded rose.

RADIANCE. A brilliant carmine-pink, with salmon-pink and yellow shadings at the base of the petals. A Rose that will withstand the most unfavorable hot summer weather.

RED RADIANCE. A counterpart of Radiance, except in color which is a clear cerise-red. A most valuable addition to our list of Roses.

SOUVENIR DE CLAUDIUS PERNET. This new yellow Rose promises to become what has long been wanted-a hardy, everblooming real yellow.

The above 14 varieties are strong pot-grown plants. We offer same in 6-inch pots, at $\$ 1$ each, $\$ 11$ per doz. 

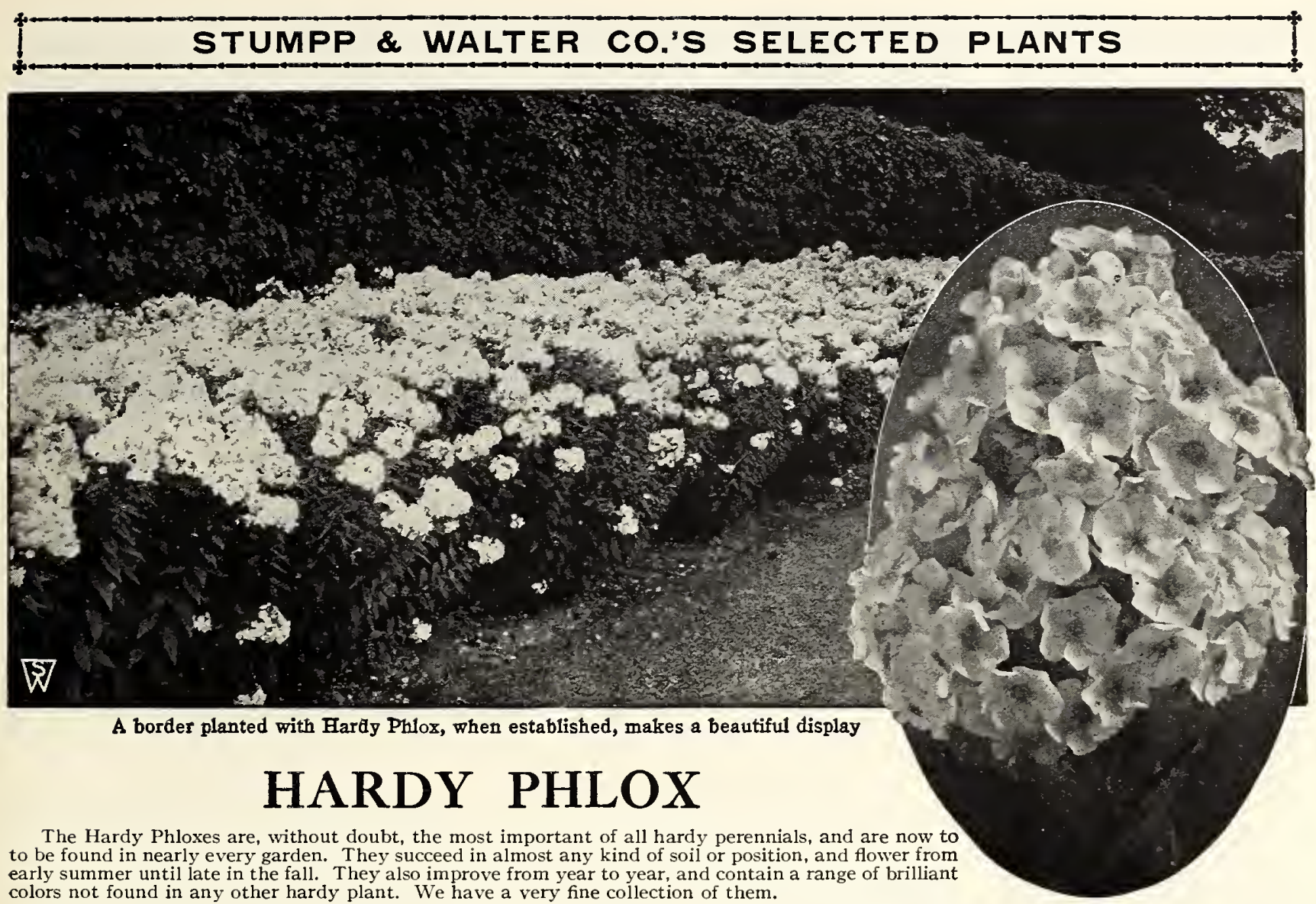
early summer until late in the fall. They also improve from year to year, and contain a range of brilliant colors not found in any other hardy plant. We have a very fine collection of them.

Culture.- Hardy Phlox may be planted in spring or fall; a mulch of old manure thrown around the roots will be of benefit to the plants. Phlox should be set out I 8 inches apart, and if kept well watered will produce both individual blossoms and heads of bloom far larger than otherwise, and amply repay the extra trouble. To procure best effects, plants should be massed in from six to twelve clumps of each variety.

AUSTRALIA. Immense crimson-purple florets.

BRIDESMAID. Pure white with large crimson center.

ELIZABETH CAMPBELL. Large, soft pink. $40 \mathrm{cts}$. each, $\$ 4$ per

doz., $\$ 30$ per IOO.

OBERGARTNER REICHENAU. Extra-large flowers of bright rose. RYNSTROM. Dark salmon-rose-the finest of its color.

COMMANDER. Crimson-red with darker eye.

WIDA. Two-toned lavender rayed with white.

Price, any of the above varieties, $30 \mathrm{cts}$. each, $\$ 3$ per doz., $\$ 20$ per 100

\section{Early-Flowering Hardy Phlox Phlox suffruticosa}

MISS LINGARD. A grand variety, which begins flowering after the middle of June and continues throughout the season. Extensively used for cut-flowers.

\section{HERBACEOUS PEONIES}

Peonies rank among the most beautiful of all hardy perennials, and no garden is complete without their charming influence. The popular interest in many parts of the world has brought a very gratifying improvement in the Peony. In the newer sorts gigantic flowers have been produced, reaching, in many instances, the large size of 7 to 9 inches in diameter and 5 to 6 inches in depth, with strong, stiff stems $21 / 2$ to 3 feet long. The permanency of Peonies should especially recommend them to your favor; for, once planted in suitable soil, they will continue to grow better and larger each year. A situation well open to the sun suits them best but they thrive in partial shade also.

Culture.-The culture of Peonies is quite simple. They require a good, deep, rich soil and an abundant supply of water during the growing season. When enriching the ground, the use of too much fresh manure near the roots should be avoided. The main point to observe is, while the ground should be well spaded and cultivated, not to plant the roots too deep. The roots should be planted so that the eyes are barely covered (about $I$ to 2 inches). Too deep planting is the cause of shy flowering.

Size of Roots.- The roots we offer have been grown two years from root divisions. If planted during April or May these roots should become well established and give some flowers the following year.

COMTE DE DIESBACH. Medium size; rich dark red; splendid grower; free bloomer; early. 50 cts. each, $\$ 5$ per doz.

DUKE OF WELLINGTON. (Calot I859.) Large; bomb type, with white guards and sulphur center. Medium tall; vigorous grower; free bloomer. Late. $75 \mathrm{cts}$. each, $\$ 7.50$ per doz.

EDULIS SUPERBA. (Lemoine I824.) Large; loose, flat crown; bright mauve-pink collar mixed with narrow lilac. Early. Strong, upright; free bloomer. One of the best commercial pinks for Decoration Day. 50 cts. each, $\$ 5$ per doz.

FELIX CROUSSE. (Crousse I 88I.) Large; globular; typical bomb; brilliant red. Strong, vigorous grower; medium height; free bloomer. One of the best reds, 75 cts. each, $\$ 7.50$ per doz.
FESTIVA MAXIMA. (Miellez I85I.) Very large; globular, rose type; pure white center, prominently flecked crimson, outer petals sometimes faint lilac-white on first opening. Very tail, strong, vigorous grower. Early. The most popular white variety for cutflowers. 6o cts. each, $\$ 6$ per doz.

LOUIS VAN HOUTTE. (Calot I867.) Medium size; semi-rose type; deep carmine-rose, tipped silver, with fiery reflex-very brilliant coloring; fragrant. Medium height and habit. Late. 60 cts. each. \$6 per doz.

RICHARDSON'S DORCHESTER. (I870.) Large, compact, rose type; pale hydrangea-pink. Fragrant. Medium dwarf; upright; free bloomer. \$I each, \$Io per doz. 


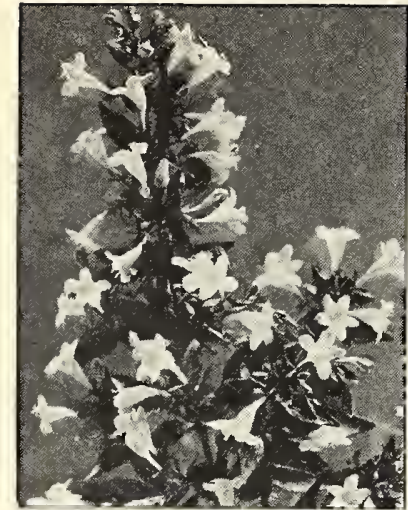

Abelia grandiflora

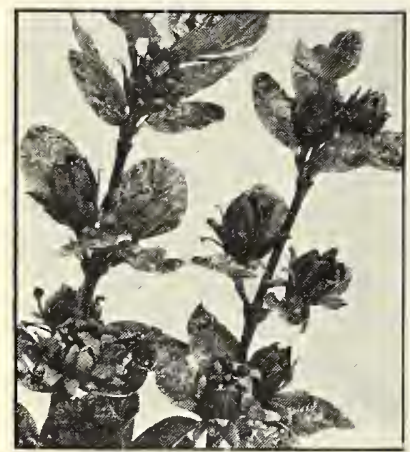

Calycanthus floridus

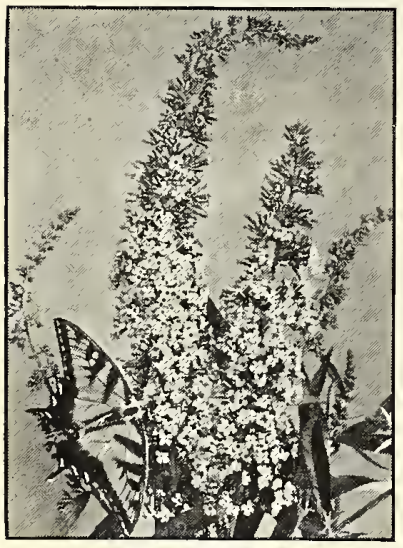

Buddleia

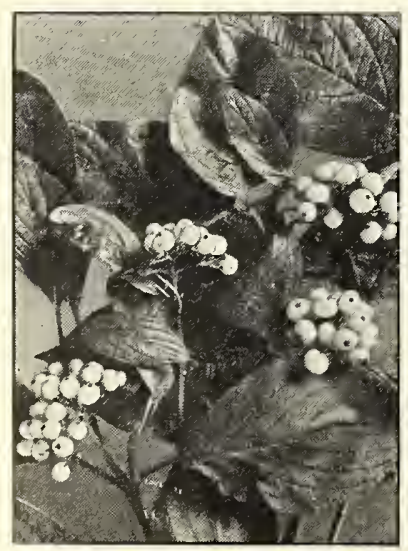

Berries of Cornus sibirica

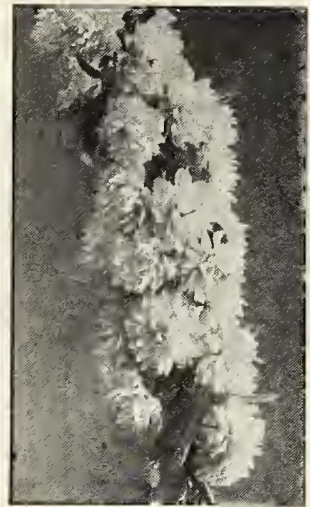

Flowering Almond

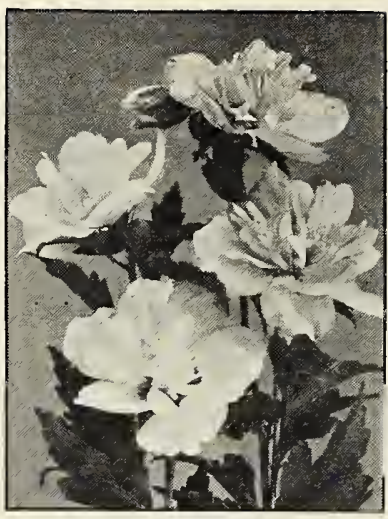

Althea

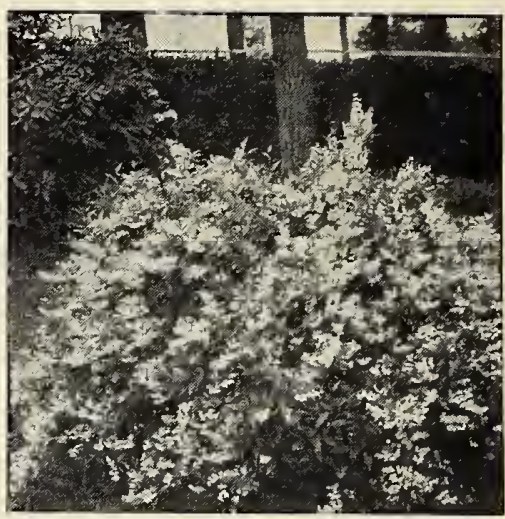

Deutzia gracilis

\section{Hardy Flowering Shrubs}

Shrubs are of great importance for the ornamentation of home-grounds. They have many uses; some are valuable as cut-flowers, while others are as decorative as any ornamental foliage plant. They may be used as a dividing-line between the flower and vegetable-garden, or between the lawn and the uncultivated land beyond, as a background for the flower border, and for hiding an unsightly building, fence or foundation. Soil where they are to be planted should be well spaded and enriched with bone-meal. Unless a very immediate effect is required, sufficient space should be allowed between them to permit of full development3 feet for dwarf varieties and 5 feet for the taller ones. As a general rule, shrubs should be thinned or pruned just after they have finished flowering, and then only slightly, just enough to keep them in nice, symmetrical shape.

NOTICE. The best time to plant is from early spring, when ground can be worked, until about May 15, the earlier the better.

\section{Abelia grandiflora}

This, to our minds, is one of the finest of all the shrubs, and should be in every foundation planting The habit and foliage is distinctly ornamental, and it blooms almost continuously from early summer until frost. The flowers are white, tinted lilac, and are produced so freely as to almost entirely cover the plants. Strong plants, $75 \mathrm{cts}$. each, $\$ 7.50$ per doz., \$6o per Ioo.

\section{Almond, Flowering Amygdalus}

This beautiful shrub is one of the loveliest. The flowers are borne on its slender branches during May, and are very fragrant.

Pink. Double-flowering; pink.

White. Double-flowering; white.

Strong plants, 2 to 3 feet, $\$ 1$ each, $\$ 10$ per doz.

\section{Althea (Rose of Sharon)}

The Altheas are among the most valuable of our tall, hardy shrubs on account of their late season of blooming, which is from August to October, a period when few shrubs are in flower. They are extensively used as hedge plants, for which they are admirably adapted. We offer in four distínct colors. Red, Pink, White, and Purple. Strong plants, 2 to 3 feet, 75 cts. each, $\$ 7,50$ per doz.

\section{Buddleia variabilis Veitchiana \\ Butterfly Shrub, Summer Lilac}

One of the most desirable of summer-flowering shrubs, beginning to bloom in July and continuing until cut down by severe frost. The flowers are of a pleasing shade of violet-mauve, and are borne in dense, cylindrical spikes from I2 to I5 inches in length by 3 inches in diameter. It succeeds everywhere, and flowers the first season it is planted. The plant dies down in winter, coming up the following spring. Strong plants, 75 cts. each, $\$ 7.50$ per doz.

\section{Calycanthus}

Floridus (Sweet or Strawberry Shrub). A very pretty shrub flowering during May. The flowers are double, chocolate-colored, and strawberry scented. Strong plants, 2 to 3 feet, 75 cts. each, $\$ 7.50$ per doz.

\section{Deutzias}

Well-known, prof use-flowering shrubs blooming in early summer. They succeed well in any sunny position.

Gracilis. A great favorite, dwarf,covered with spikes of pure white flowers in early summer. Strong plants, II $1 / 2$ to 2 feet, $75 \mathrm{c}$. each, $\$ 7.50$ per doz.

Pride of Rochester. A fine, tall-growing, double, white-flowering variety. Strong plants, 2 to 3 feet, 75 cts. each, $\$ 7.50$ per doz.

\section{Dogwood (Cornus)}

This is a very well-known shrub. The flowers appear in May, before the foliage. In autumn it takes on a rich crimson shade.

Sibirica (Siberian Dogwood). A strong-growing variety with white flowers. The branches are crimson colored in winter. Strong plants, 2 to 3 feet, 75 cts. each, $\$ 7.50$ per doz.

\section{Forsythia}

Viridissima (Golden Bells). A tall, erect shrub covered with golden yellow bells in early spring before the foliage ap pears. Strong plants, 2 to 3 feet, $75 \mathrm{cts}$. each, $\$ 7.50$ per doz.

\section{Hydrangea}

We offer two varieties of this, perhaps the most popular of flowering shrubs.

Arborescens grandiflora (Snowball Hydrangea). This magnificent, perfectly hardy American shrub has snow-white blossoms of largest size. One of its most valuable characteristics is its coming into bloom just after the passing of all the early spring-blooming shrubs, flowering from early June to late July. Strong plants, 75 cts. each, \$7.50 per doz.

Paniculata grandiflora. Considered the most popular summer-flowering shrub. The flowers, which are borne in dense, pyramidal panicles a foot long, in greatest profusion, are white when they first open but gradually change to rose color, and remain in good condition for weeks. Strong plants, 75 cts. each, $\$ 7.50$ per doz. 


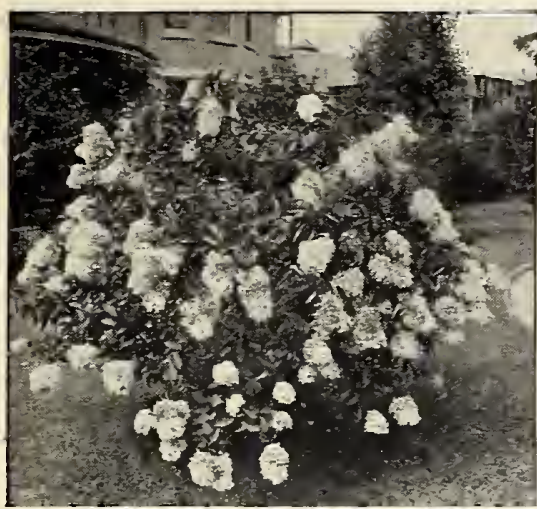

Hydrangea paniculata grandiflora

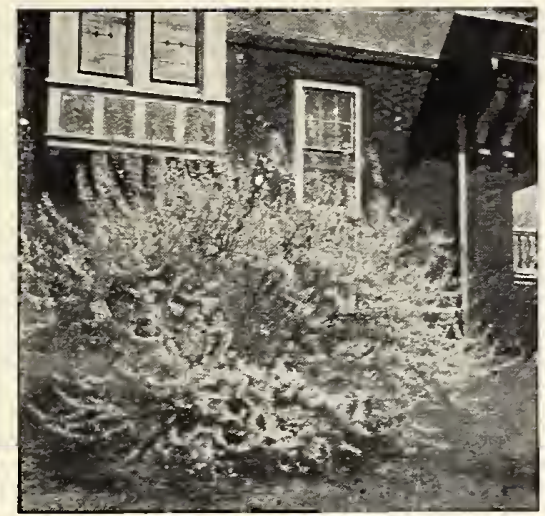

Forsythia viridissima

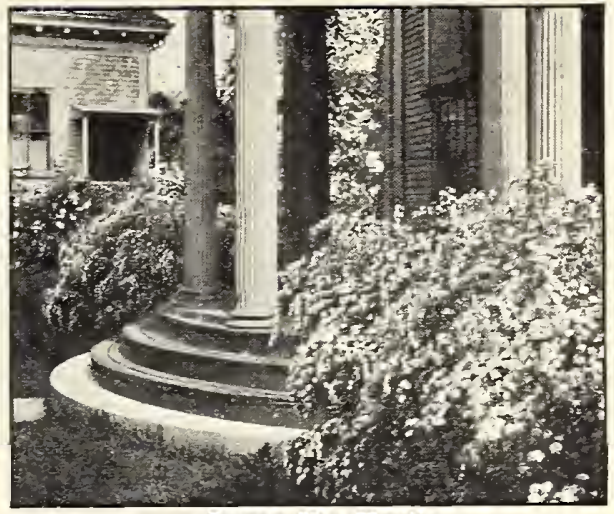

Spiræa Van Houttei

\section{Kerria (Corchorus)}

One of the most graceful and beautiful of the lower-growing shrubs for the front of a shrubbery border, or in a mixed planting of low shrubs around porches.

Japonica. Attractive golden yellow flowers are borne continuously from June to October. Strong plants, \$I each, \$Io-per doz.

\section{Philadelphus (Mock Orange)}

This old-fashioned sweet-scented shrub has long been a close rival of the lilac in popularity. Coronarius (Garland Mock Orange). This is a popular tall variety, refined and beautiful; large white flowers. Strong plants, $75 \mathrm{cts}$. each, $\$ 7.50$ per doz.

\section{Pyrus japonicus} Japan Quince

A very showy and popular shrub of medium height, which blooms profusely in early spring; flowers dazzling scarlet. Makes an excellent hedge-plant. Strong plants, \$I each, \$Io per doz.

\section{Prunus}

We offer two varieties of the Flowering Plum. Pissardii (Purple-leaved Plum). A dwarf shrub covered with single white flowers in spring. When they first appear the leaves are a lustrous crimson, changing to rich purple.

Triloba (Double-flowering Plum). An interesting shrub, of medium height, bearing in early spring semi-double, delicate pink flowers over an inch in diameter.

Either of the above, strong plants, $\$ 1$ each, $\$ 10$ per doz.

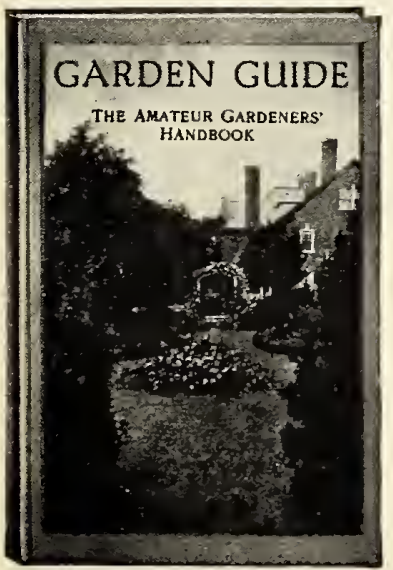
removed.

\section{Symphoricarpos}

Racemosus (Snowberry). A well-known dwarf shrub with pink flowers and white berries that hang on the greater part of the winter. Strong plants, $75 \mathrm{cts}$. each, $\$ 7.50$ per doz.

Vulgaris (Red-fruited or Indian Currant). Similar to the above, but with bright red fruit. Strong plants, $75 \mathrm{cts}$. each, $\$ 7.50$ per doz.

\section{Syringa, or Lilac}

We offer two of the common varieties of Lilac, but will be pleased to correspond with our customers who are desirous of growing the better named varieties.

Common Purple (Syringa vulgaris). Purple. Common White ( $S$. vulgaris alba). White.

Either of the above, strong plants, $75 \mathrm{cts}$. each, $\$ 7.50$ per doz.

\section{Viburnum}

Plicatum (Japan Snowball). One of the choice hardy shrubs, with healthy dark green foliage. The perfect balls of pure white flowers are borne in great profusion in May. Strong plants, \$I each, \$Io per doz.

Opulus (High-Bush Cranberry). The white flowers in June are followed in autumn by bright scarlet berries, which are very attractive until late in winter. Strong plants, 75 cts. each, $\$ 7.5^{\circ}$ per doz.

\section{Weigelas}

These easily take rank among the most popular flowering shrubs, covered, as they are, in May and early June by their large, trumpetshaped flowers.

Eva Rathke. Considered the finest Weigela in cultivation. The flowers are a rich rubycarmine. Strong plants, $75 \mathrm{cts}$. each, $\$ 7.50$ per doz.

\section{Spiræa}

Anthony Waterer. A valuable variety. Color bright crimson. It is of dwarf, dense growth, never exceeding 30 inches in height and blooms the entire summer and fall, if the old flower-heads are

Van Houttei (Bridal Wreath). The grandest of all the white Spireas. It is of compact habit and a beautiful ornament for the lawn at any season, but when in flower is a very beautiful sight, the white blooms almost entirely covering the foliage.

Either of the above, strong plants, $75 \mathrm{cts}$. each, $\$ 7.50$ per doz.

\section{Garden Guide}

A complete handbook for the amateur gardener. Has wonderful chapters devoted to the Vegetable, Flower, and FruitGarden, with practical planting plans. It tells you how to prepare and fertilize your ground, how to deal with insect pests, how to prune, propagate, spray; in fact, covers every step from spading to preserving the harvest. 384 pages. $\$ 1$, mailed free.

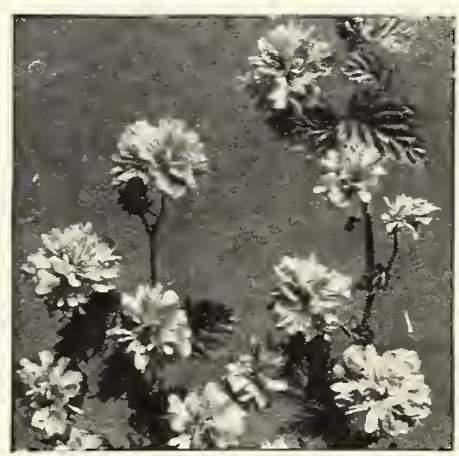

Kerria japonica

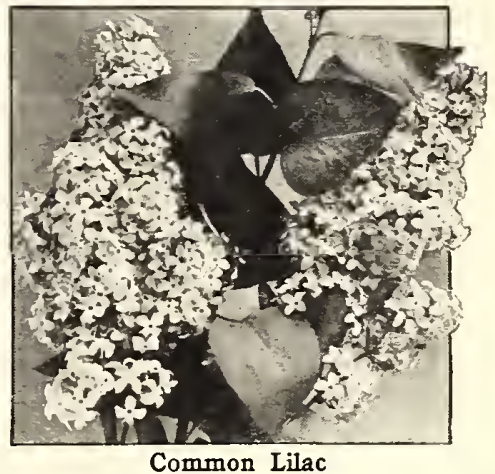

Common Lilac

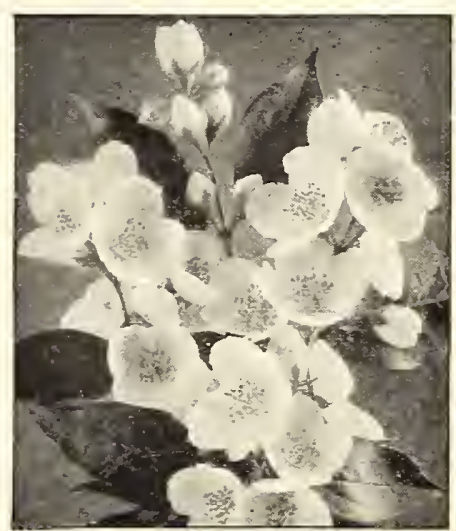

Philadelphus coronarius 


\section{HARDY CLIMBING PLANTS}

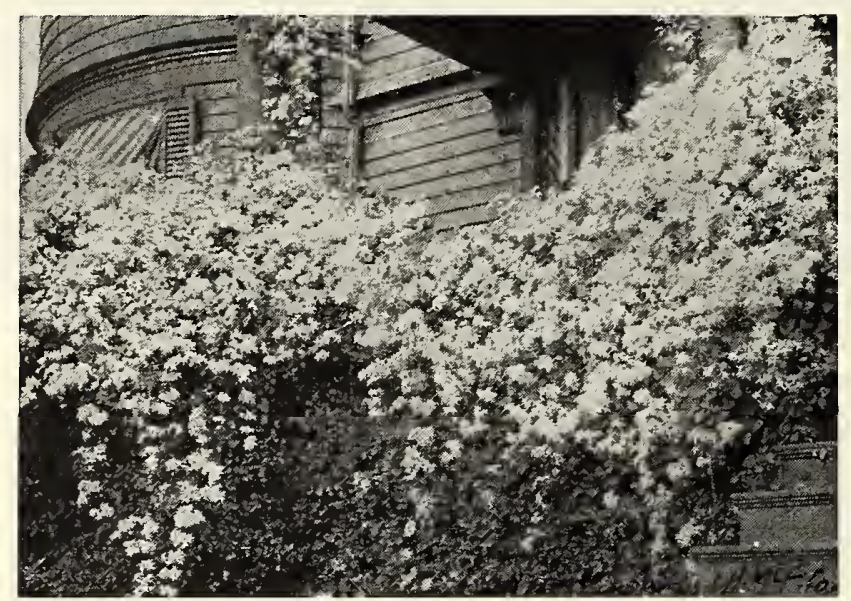

Clematis paniculata

AMPELOPSIS

(Sometimes called Boston Ivy and Japan Ivy)

VEITCHII. This is the most deservedly popular of all climbing plants, being entirely hardy in the most exposed places and attaining a height of 30 feet in two or three years; clings to stones, brick or woodwork with the greatest tenacity. During the summer the leaves are a rich shade of green and lap over each other with great regularity, like a coat of mail or like slates on a roof. But it is in the fall that it shows its exquisite beauty. The leaves then change to the brightest tints of scarlet, crimson and orange, so dazzling as to be seen at a great distance. Extra strong, field-grown plants, 50 cts. each, $\$ 5$ per doz., $\$ 40$ per Ioo.

\section{CLEMATIS}

The Clematis we offer this season are exceptionally fine, strong 2year-old plants. We have reduced the number of varieties to such sorts as, from experience, we know to succeed best in our climate. Many failures in the growing of Clematis are the result of too shallow planting. The crown of the roots should be set at least 3 inches below the surface of the soil.

PANICULATA (Japanese Virgin's Bower). Small-flowering type This is one of the choicest and most satisfactory climbing flowering plants we know. The plant is of strong, rapid growth, with small, dense, cheerful green foliage, giving it a grace and elegance possessed by no other hardy climber. The flowers appear in the greatest profusion during August, and continue until late in the fall, are white in color and most deliciously fragrant. The plant succeeds in almost any position; not only is it well adapted to run up all kinds of supports, but is just as useful for planting among rockwork, sloping banks, covering graves, or, in fact, in any position where a graceful vine is desired. Strong, field-grown plants. 50 cts. each, \$5 per doz., \$40 per roo.

JACKMANII. The best-known large purple-flowering variety. $\$ I$ each, \$10 per doz., \$75 per 100.

\section{HONEYSUCKLE (Lonicera)}

HALLIANA (Hall's Japan Honeysuckle). A strong, vigorous, almost evergreen sort; white flowers changing to yellow; very fragrant; flowering from July to December; holds its leaves nearly all winter. Extra-selected plants, $50 \mathrm{cts}$. each, $\$ 5$ per doz., $\$ 40$ per Ioo.

\section{WISTARIA}

SINENSIS (Chinese Wistaria). A most beautiful climber of rapid growth. When well established it makes a growth of I5 to 20 feet in a season. Flowers pale blue. Extra-strong plants, \$I each, \$1o per doz., \$75 per Ioo.

\section{HEDGE PLANTS}

We offer two of the principal shrubs that are extensively used for Hedge Plants

\section{BERBERIS THUNBERGII}

\section{Japan Barberry}

Where a dwarf, deciduous hedge is wanted, nothing equals this beautiful Barberry. It requires but little pruning to keep it in shape. The leaves are small, light green, and towards fall assume rich, brilliant colors, the fruit or berries becoming scarlet. It is used extensively throughout the country and is perfectly hardy. Extra-strong, I $1 / 2$ to 2 feet, 4 to 6 branches, packed in bundles of Io or 25 , at $\$ 4$ for Io, $\$ 7.50$ for $25, \$ 25$ per IOo.

\section{CALIFORNIA PRIVET Ligustrum ovalifolium}

This is, perhaps, the most popular of all the hedge plants. Being absolutely hardy, it increases in beauty with each successive year. To get best results, plants should be set I foot apart in double rows in zigzag fashion, so that the plants are diagonally opposite each other. This practically places them 6 inches apart, which is desirable to get quick, dense growth. May be planted from March ${ }_{5}$ to May I 5, or from October to frost. Extra-strong, $2 \mathrm{ft}$., $\$ 1.50$ for $25, \$ 5$ per I00, \$45 per I,00o.

\section{FRUIT TREES}

Extra-selected 3-year-old stock of the leading varieties of Apples (\$1.50 each); Pears (\$2.50 each); Cherries (\$4 each); Plums (\$2.50 each); Peaches ( 75 cts. each).

SMALL FRUITS Prices on application

$\begin{array}{lll}\text { Blackberries } & \text { Currants } & \text { Gooseberries } \\ \text { Grape-Vines } & \text { Raspberries } & \text { Strawberries }\end{array}$

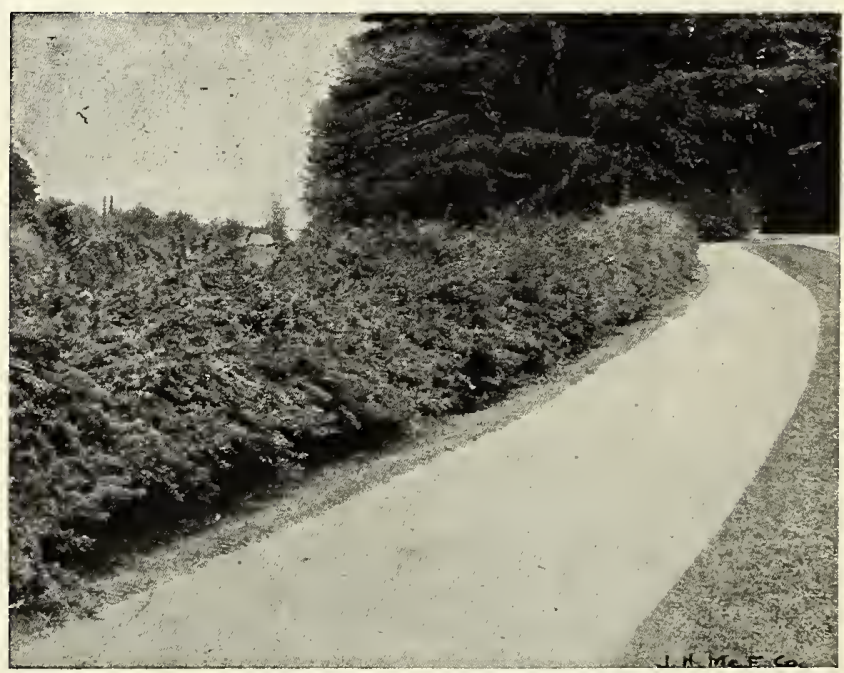

Hedge of Berberis Thunbergii

No Bedding Plants, Vegetable Plants, or Nursery Stock delivered C. O.D. All plants shipped at owner's risk 


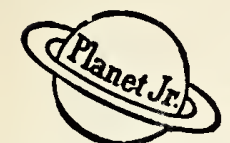

\section{Planet Jr.Farm and Garden Tools}

72-page Planet Jr. catalogue free. Describes 70 tools, including Seeders, Wheel Hoes, Horse Hoes, Harrows, Cultivators. Write postal for it

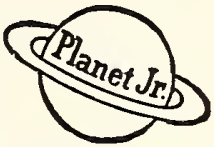

They cut down work and boost your crops. These scientific tools do the work of three to six men, give bigger yield, and save their cost in a single season. Invented and made by a practical farmer and manufacturer, with half a century's experience. Planet Jrs. are strong and lasting. Every tool fully guaranteed. Come and let us convince you of their economy. THE FOLIOWING PRICES ON PLANET JR. ARE SUBJECT TO CHANGE WITHOUT NOTICE.

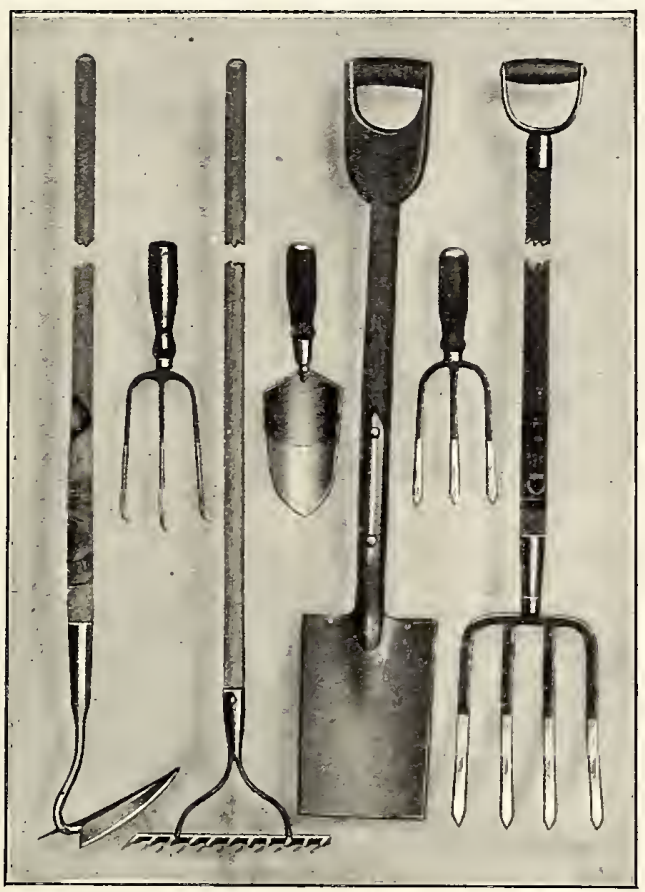

\section{S. \& W. Co.'s Garden Tool Sets}

The S. \& W. Co.'s Garden Tool Sets are selections of the most useful tools of the size and kind used in the garden. They are light but strong and consist of I Spade, I Digging Fork, I Rake, I Hoe, I Trowel, I Hand Fork, and I Hand Weeder. Every tool is of good quality, weIl made, and will give good service. Price, $\$ 7$. Ladies' and Children's Set, I Shovel, I Hoe, I Rake, and I Spading Fork, \$3.50.

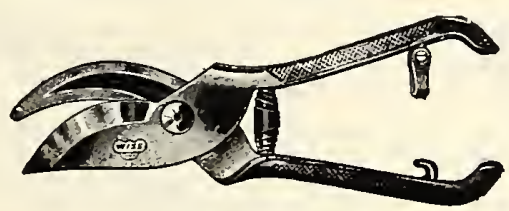

\section{Sawco Shears}

For pruning. Especially recommended for florists' use, nurserymen and large estates, where the low price would warrant the purchase of the Shears in half-dozen and dozen lots. American made, of the finest steel; sharp cutting and long wearing. Each, $\$ 1.50$, doz. $\$ 17$.

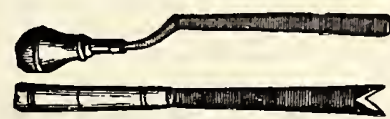

\section{Asparagus Knives}

American.

Straight Edge. $50 \mathrm{cts}$. each, $\$ 5.50$ per doz.

$\nabla$-Shape. $50 \mathrm{cts}$. each, $\$ 5.50$ per doz.

\section{No. 11 Planet Jr. Double Wheel}

Hoe, Cultivator and Plow

A Single- and Double-Wheel Hoe

in one. Straddles crops till 20

inches high, then works between.

Has steel frames and 14 -inch steel wheels. The greatest hand-cul-

tivating tool in the world.

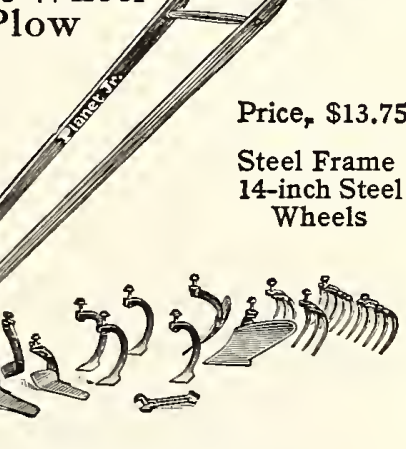

\section{Combined Seeder and Cultivator} SINGLE WHEEL

Will sow seeds in rows or in hills; will plow open furrows and cover them, cultivate and hoe. The seeding mechanism holds $2{ }^{1} / 2$ quarts of seed, and in addition the outfit consists of I pair of 6-inch Hoes, 3 Cultivator Teeth, I Plow, I Leaf Guard, and I adjustable Marker. Price, \$21.50.

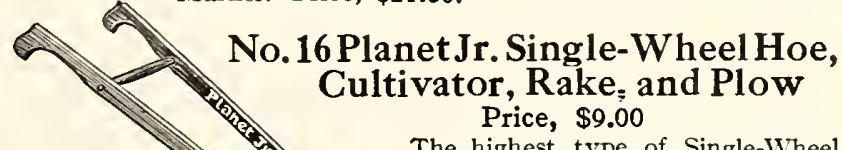

The highest type of Single-Wheel Hoe made. Light, but strong, and can be used by man, woman, or boy. Will do

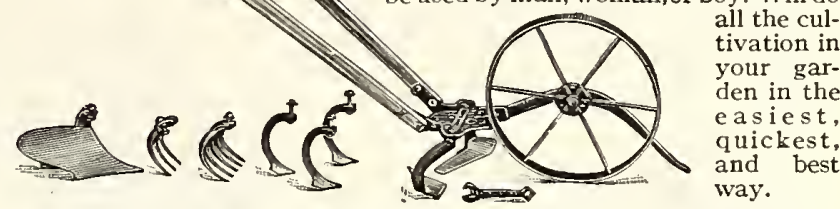

No. 17 Planet Jr. Single-Wheel Hoe. Price, $\$ 7.75$

Has a pair of 6 -in. hoes, a plow, and a set of cultivator teeth; sufficient for roost garden work.

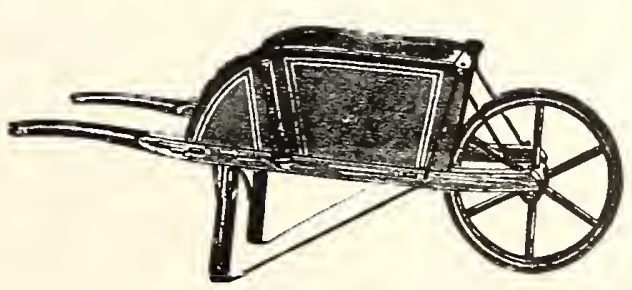

\section{S. \& W. Co.'s Garden Barrow}

One of the most useful articles on the list of garden and lawn tools. Materials are selected oak, mortised and bolted together, strengthened with six iron braces. Made substantial, light and for long service. Wheels with 3 -inch tread, except boys' size.

\begin{tabular}{|c|c|c|c|c|c|c|c|}
\hline \multirow{2}{*}{ SIZE } & \multirow{2}{*}{$\begin{array}{l}\text { Front } \\
\text { Width }\end{array}$} & \multicolumn{2}{|c|}{ SIZE OF BOX } & \multirow{2}{*}{$\begin{array}{c}\text { Rear } \\
\text { Width }\end{array}$} & \multicolumn{3}{|c|}{ SIZE OF WHEEL } \\
\hline & & Depth & Length & & Diam. & Tread & Price \\
\hline $\begin{array}{l}\text { Medium . . . . . . } \\
\text { Regular . . . . . . } \\
\text { Boys' ........ }\end{array}$ & $\begin{array}{l}18 \mathrm{~T} / 2 \mathrm{in} . \\
20 \text { in. } \\
15 \mathrm{r} / 2 \text { in. }\end{array}$ & $\begin{aligned} & 2 \text { in. } \\
12 & \text { in. } \\
9 & \text { in. }\end{aligned}$ & $\begin{array}{l}26 \mathrm{I} / 2 \mathrm{in} . \\
28 \mathrm{in} . \\
2 \mathrm{I} \text { in. }\end{array}$ & $\begin{array}{l}23 \text { in. } \\
24 \text { in. } \\
\text { I } 8 \text { in. }\end{array}$ & $\begin{array}{l}20 \text { in. } \\
22 \text { in. } \\
16 \mathrm{in.}\end{array}$ & $\begin{array}{l}3 \text { in. } \\
3 \text { in. } \\
1 / 2 \text { in. }\end{array}$ & $\begin{array}{r}\$ 8.50 \\
9.50 \\
6.75\end{array}$ \\
\hline
\end{tabular}




\section{Garden and Lawn Tools}

\section{Forks}

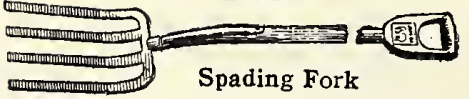

Spading Forks. Best grade; tines spearpointed with diamond-shaped backs; handle strapped both sides. Of superior quality and very strong. Each 4-tine, D Handle ............ \$2 25 5-tine, $\mathrm{D}$ Handle $\ldots \ldots \ldots 275$ Long-Handle Forks, same price. $\rightarrow 00$

Manure Forks. Best grade; strong oval tines. 4-tine, D Handle .............. \$2 oo 5 -tine, D Handle.................. 2 6-tine, D Handle................. 2 50

Long-Handle Forks, same price.

Hay Forks.

Best grade; strong oval tines, made only with long handles. Each 3-tine, Long Handle.......... \$I 65 4 -tine, Long Handle.............. I 75 Boys' Spading Forks.

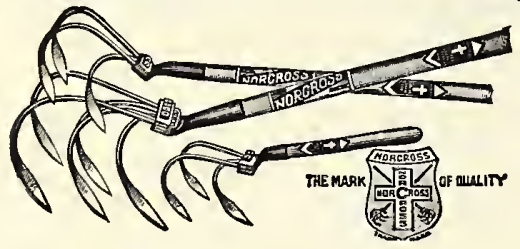

\section{Norcross Cultivator Hoe and Weeder}

Wherever vegetables, plants and flowers are grown, these modern tools are rapidly replacing the ordinary Hoe. They are made in three sizes, and can be used in wide or narrow rows. Will also cultivate both sides of a row at one operation, when the middle prongs are removed. The three-prong Weeder is the women's size. They destroy weeds, leave the soil level, loose and untrampled. 5-prong, $\$ \mathrm{I} .4 \mathrm{O} ; 3$-prong, $\$ \mathrm{I}$; Midget, $65 \mathrm{cts}$.

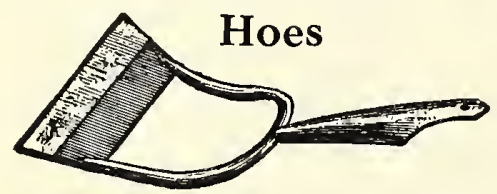

English Scuffle Hoe. Imported. Positively the best. The quality of material used and finish is superior to all others.

Size Each Size Each 4 -in........ \$I oo 8 -in.......... \$ I 40 5 -in........ I 10 9 -in.......... I 50 6 -in........ I 20 10-in......... I 70 7 -in......... I 30

Extra-strong handles, $4 \frac{1}{2} \quad \mathrm{ft} ., 50 \mathrm{cts}$; $6 \mathrm{ft}$., $80 \mathrm{cts}$. each.

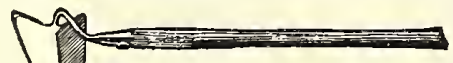

Warren, or Heart-Shaped. The best Hoe for making drills, covering, hoeing, and weeding.

Small size

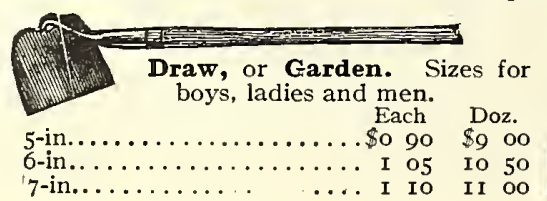

HOES, continued

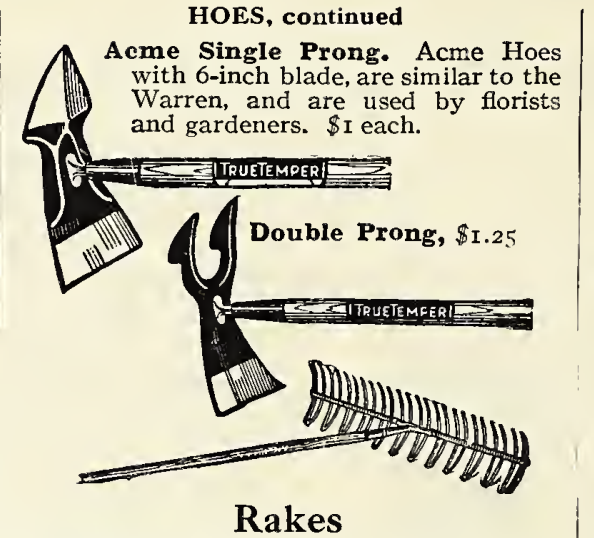

Reversible Steel. Suitable for lawn and garden. Has 24 teeth. $90 \mathrm{cts}$. each.

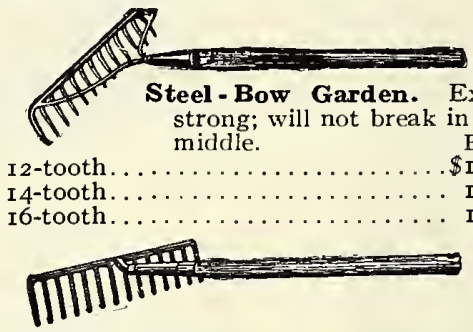

Steel Garden. Cut from one piece of steel; strong and durable.

Each
Io-tooth....\$I oo
I4-tooth...... EI 20 I 2 -tooth..... I I 10 I6-tooth....... I 30 Steel Gravel. Like the Garden Rake. Made
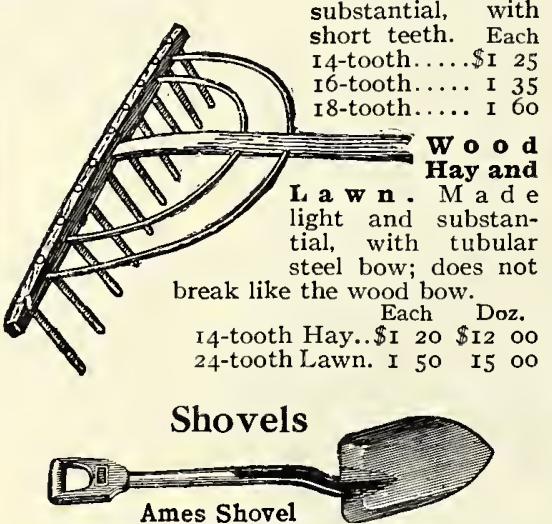

Ames Shovels are the best manufactured give best service.

Square Point, D Handle. ............ 8275

Round Point, D Handle......... 275

Long-Handle Shovels, same price.

S. \& W. Co.'s Shovels.

Square Point, D Handle.......... I 75

Round Point, D Handle........... I 75

Long-Handíe Shovels, same price.

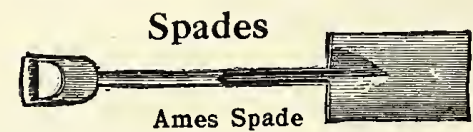

Ames Spades are the same grade as the Ames Shovels. Each D Handle and Long Handle...... \$2 75 S. \& W. Co.'s Spades are the same grade as S. \& W. Co.'s Shovels. Each

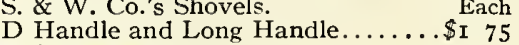
Boys' Spades................... I 75

\section{Dibbles or Dibbers}

Just the tool for transolanting tomatoes. cabbage, celery, etc.

B $\mathbf{r}$ a $s$

poi n t

a $n$ d

Brass Dibber

wood handle. The best Dibber.

Polishes quickly; does not rust.

$\$ 1.25$ each, \$12 per doz.

Steel point and wood handle. Regular size, 93/4 in., \$I each, \$10 per doz. Small size, 8 in., 90 cts. each, $\$ 9$ per doz.

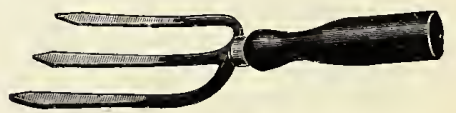

\section{Gem Hand Fork}

Has three steel prongs and finished handle. Is a handy Fork for transplanting strawberries, loosening the soil, etc. $60 \mathrm{cts}$. each.

\section{Grass Hooks}

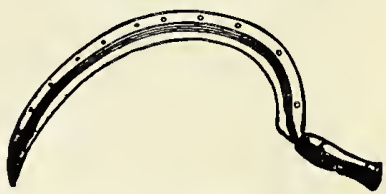

Imported English. With heavy riveted back, thin cutting blade, easy to sharpen; forged from the best-grade steel. Medium, $\$$ I; Large, \$I.I5.

\section{Grass and Lawn Scythes}

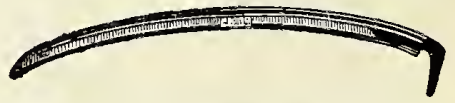

Domestic. Cutlery steel, natural oil finish, cutting edge, web and back polished.

32 -in......\$2 $35 \mid 36$-in........\$2 60

Scythe Snath or Handle. The very best, with patent socket. $\$ 2.50$.

\section{Trowels}

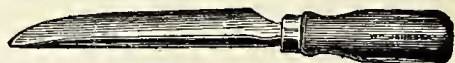

Slim Jim. Excellent for setting bulbs or transplanting. 5 -inch size, 20 cts.; 7 -in. size, $30 \mathrm{cts}$. each.

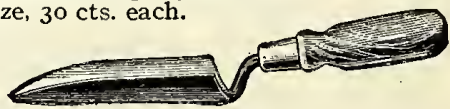

Forged Steel. This Trowel is second to the Stumpwall Trowel in quality and finish. The blade and shank are one piece, forged out of the best of steel. Made in three sizes. 5 -in., 65 cts.; 6-in., 75 cts.; 7 -in., 85 cts.

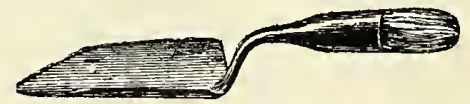

Stumpwall is the best made Trowel. The ferrule and shank, as well as the blade, are forged in one piece. Only the very best material used. 6-in., \$I each.

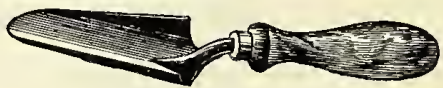

Florists' Steel Trowel

This Trowel is made in one piece of heavy sheet steel. One size only, 6-in., $50 \mathrm{cts}$. each. 


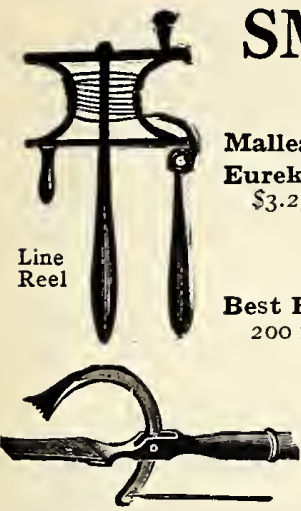

SMALL GARDEN

\section{Garden Line Reel}

Malleable Iron. Holds Ioo feet. \$1.25.

reka. Galvanized steel. Single, 500-foot size, 3.25. Double, I,000-foot size, \$4.

\section{Garden Line}

est Braided Linen. I oo feet, one length, $\$ 1.75$, 00 feet, one length, $\$ 3 \cdot 50$.

TOOLS, FLOWER POTS

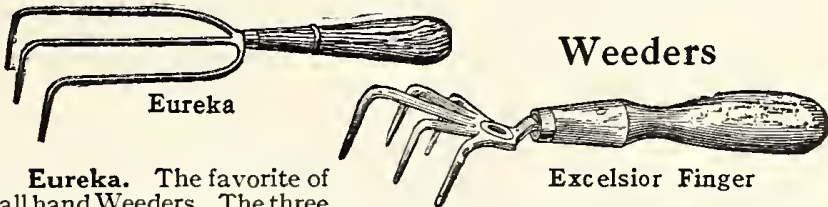
Ell hand Weeders. The three

solid steel prongs are set $I I / 2$ inches apart to allow cultivation between two or more plants at once. Short handle, $60 \mathrm{cts}$. each. Larger size, 24-inch handle, $70 \mathrm{cts}$. each.

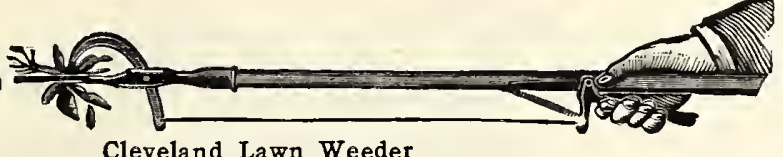

Excelsior Finger. This five-short-prong Weeder is excellent for loosening the soil in small flowerbeds, etc. $35 \mathrm{cts}$. each, $\$ 3.50$ per doz.

Cleveland Lawn. Is simple to operate; it not only saves the back, but is actually a pleasure to use. The cut is a good illustration, showing how to work it. \$I.50 each, \$I5 per doz.

\section{Tubs}

Plant Tubs, New York Cedar. Made of the choicest seasoned cedar, highly finished with black hoops: will last twice as long as cypress.

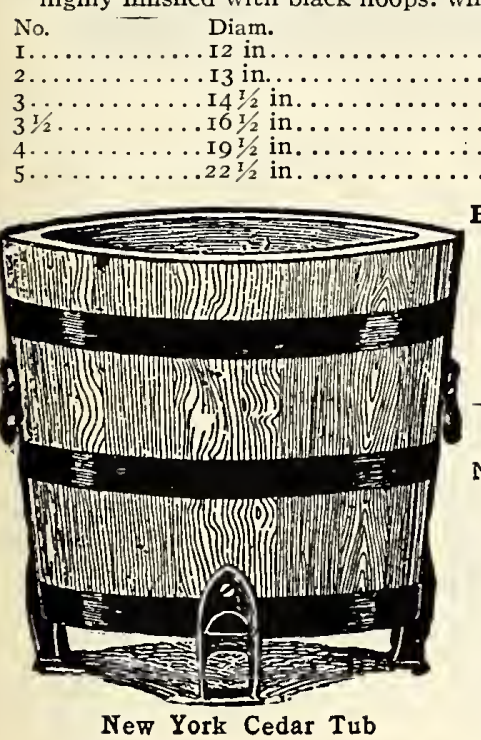
Height Price I0 $1 / 2$ in...........\$2 50 I 3 in............. 350 I 5 in $\ldots \cdots \cdots \cdots+425$ 17 in .........6 6 oo

Barclay Tree Tubs. Made of seasoned, selected Virginia White Cedar; bound with electric-welded wire hoops (galvanized), three hoops to each, except the smallest two tubs which have two.

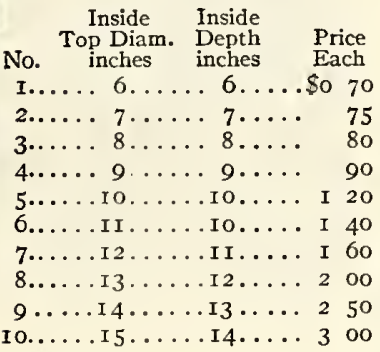

\section{Plant Stakes and Supports}

Bean Poles. Excellent for staking Pole Lima Beans. $30 \mathrm{cts}$. each, $\$ 3.50$ per doz., \$25 per 100.

Plant, Tapering, GreenI $1 / 2$ feet.

$2 \mathrm{feet}$

3 feet.

4. feet.

5 feet. :

Dahlia Poles, Tapering. 3 feet.

Doz. $\quad 100$

.\$o $35 \$ 225$

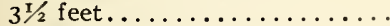

4 feet.

5 feet.

Chinese Tonkin Cane. These are Chinese canes, very strong heavy. 2,3 , and 4 -ft., $1 / 4$ to $1 / 2$-in. diam.; 5,6 , and 7 -ft., $3 / 4$-in. diam.

2 feet.

Soz.

3 feet

4 feet...............

5 feet.

7 feet.
IOO $I, 000$

\$I 50 \$IO OO

2 o0 17 o0

5 50 4500

$650 \quad 5500$

$750 \quad 65$ o0 $\begin{array}{llll}3 & 75 & 33 & 00\end{array}$

Flower Pots, Standard

EARTHENWARE. Best on the market Diam. Each Doz. I00 I,000 2 in........ \$o 25 \$I 50 \$I 200 $2 \mathrm{I} / 2$ in...... $30 \quad$ I 75 I5 3 in....... $\quad 40 \quad 250 \quad 2000$ 4 in....... $60 \quad 400 \quad 3000$ 5 in....... So Io I Io $700 \quad 5500$ $6 \mathrm{in} . . . \ldots$ I... I5 I 60 I0 $00 \quad 8200$ 7 in........ $25 \quad 260$ I6 $00 \quad 13000$ 8 in....... $35 \quad 3202000$ I 8000 On orders of 50 pots or more we make shipment direct from factory to customer.

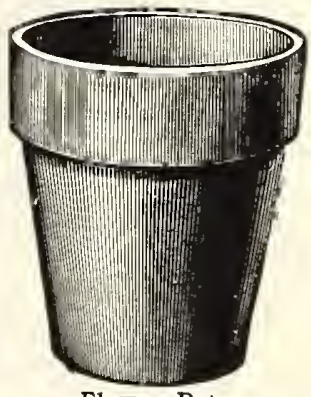

Flower Pot

Saucers of same material, to fit Pots, furnished extra

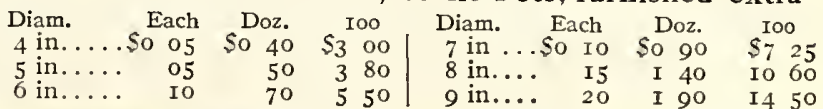

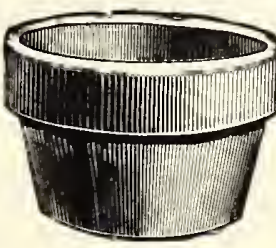

Bulb Pan

\section{Bulb Diam. \\ 6 in. \\ 7 in. \\ 9 in. \\ I2 in.}

b Pans.

\begin{tabular}{|c|c|c|}
\hline \multicolumn{3}{|c|}{ EARTHENWARE } \\
\hline $\begin{array}{l}\text { Each } \\
\text { So I } 5\end{array}$ & $\begin{array}{l}\text { Doz. } \\
\text { \$I } 50\end{array}$ & $\begin{array}{l}100 \\
\text { SIO }\end{array}$ \\
\hline 25 & 250 & I5 $\mathrm{O}$ \\
\hline 30 & 300 & 2200 \\
\hline 50 & 500 & 4000 \\
\hline 70 & 700 & 5000 \\
\hline I 25 & I2 50 & 900 \\
\hline
\end{tabular}

Paper Flower Pots, Neponset

Very economical; waterproof; can be nested closely for shipping.

Diam.

$21 / 4$ in

$21 / 2$ in.

3 in 3 in

4 in....

5 in...

6 in....
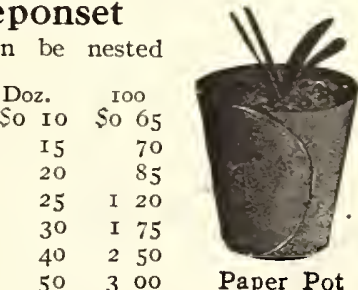

Paper Pot

\section{Pot or Garden Labels}

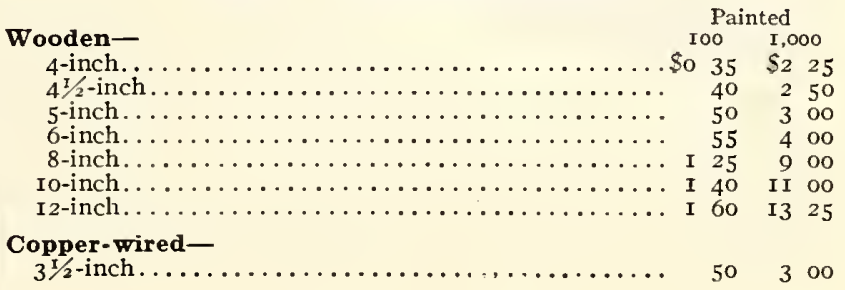




\section{Welf- Watering Hanging-Baskets and Boxes, Lawn Rollers, Etc. PRICES SUBJECT TO MARKET CHANGES}

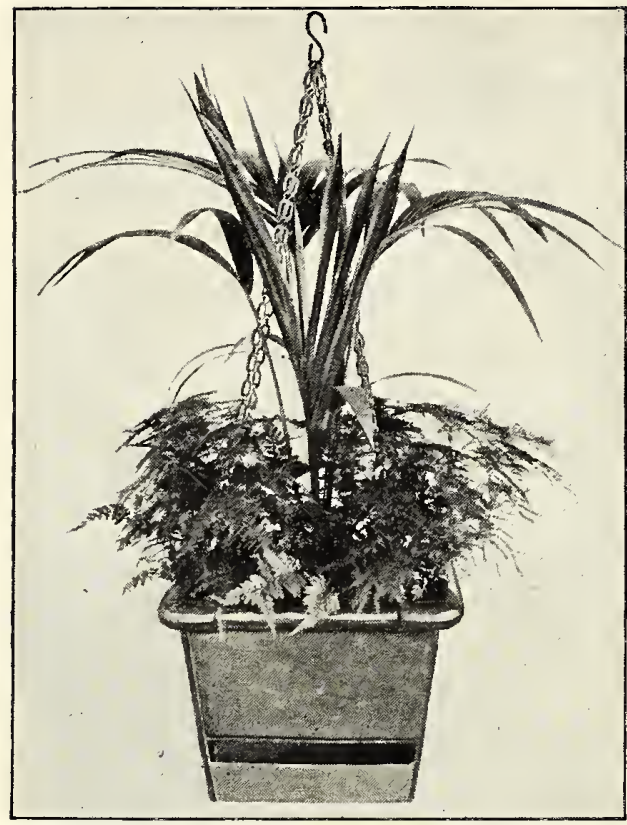

The S. \& W. Co.'s Irrigating Hanging-Baskets
The S. \& W. Co.'s Irrigating Hanging-Baskets

The S.\&W. Co.'s Irrigating Basket is a strongly made, water-tight, galvanized square steel box, attractively finished with a baked-on enamel in dark green. Its neat design harmonizes with any surrounding. The top edges have a pleasing roll finish and the boxes are made entirely suitable for all locations. Four chains are furnished with which the basket may be suspended anywhere--indoors or out.

There is a water-pocket at the bottom, and, leading from it into the box, are tubes to convey water to the soil. Watering is made easy, the air circulation is perfect, and the soil is kept sweet and healthy. What is more important, the plants get the water at the roots, right where it does the most good.

Io inches square...........\$2 $35 \mid$ I 6 inches square...........\$4 00 I 2 inches square $\ldots \ldots \ldots \ldots \ldots \ldots \ldots \ldots \ldots \ldots \ldots$ 14 inches square............ 325

\section{The S. \& W. Co.'s Irrigating Flower-Boxes}

You can put the S. \& W. Co.'s Flower-Boxes anywhere-on the piazza rail, at the edge of the piazza floor, the window-sill, and in many other places on the outside or inside of y o u $r$ home. When cold weather comes, take the boxes and plants inside and have the all-winter cheer of growing flowers.

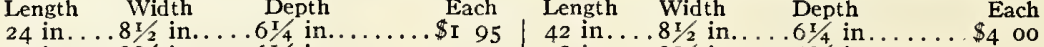

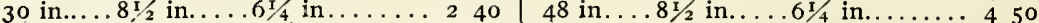
$36 \mathrm{in} \ldots 8 \mathrm{~s} / 2$ in.... $6 \mathrm{r} / 4 \mathrm{in} \ldots \ldots . .325$

\section{All-Iron Hose Reel}

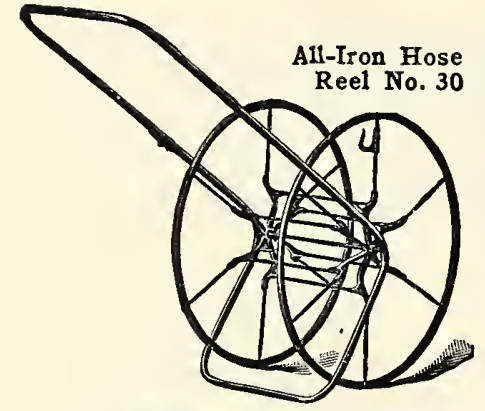

The All-Iron Hose Reels are constructed entirely of iron, and are indestructible. They are light in weight, frictionless. and the wheels being high, they are easily manipulated. These Reels cannot tip over when unreeling and there is no weight on the handle.

The use of a Reel lengthens the life of your rubber hose.

No. ro, 2 I-in. wheel, holds roo feet $3 / 4$-in. hose, $\$ 5$ each.

No. 20, 24-in. wheel, holds I 50 feet $3 / 4$-in. hose, $\$ 5.50$ each. No. 30, 30-in. wheel, holds 500 feet $3 / 4$-in. hose, $\$ 9.25$ each.

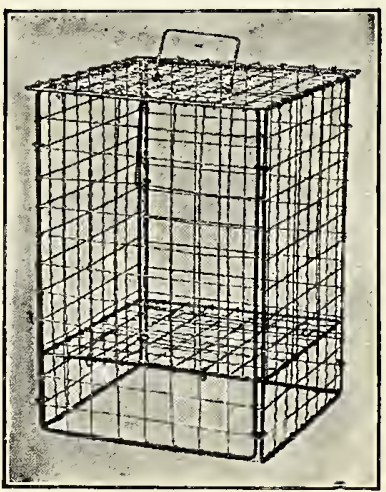

Burners for Leaves, Paper and Rubbish

The best receptacle used for burning leaves, papers, and all kinds of rubbish. This handy knock-down Burner is a safeguard against many fires that have their origin in the burning of rubbish in the open. The Burner is extra strong, manufactured of heavy galvanized steel wire, reënforced with iron supports. Made to givelifelong satisfaction. A trash-burner makes possible a tidy garden. We supply this Burner in two sizes.

No. $\mathrm{I} . . \mathrm{x}_{5}$ in. $\mathrm{x} \mathrm{I}_{5}$ in. $\mathrm{x} 22$ in.... $\$ 3$ oo $2 . .17$ in. $x 17$ in. $x 29$ in.... 400

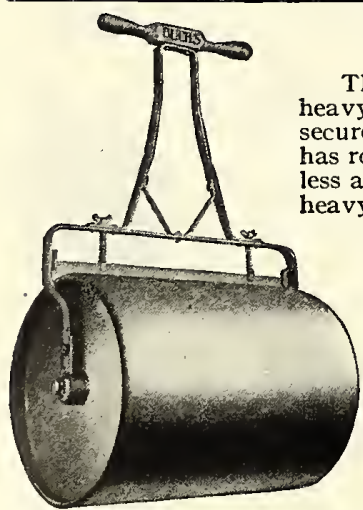

Fill it with Water or Sand

\section{Stumpp \& Walter Co.'s "Water-Ballast" Lawn Roller}

The Stumpp \& Walter Co.'s Water-Ballast Roller is a most satisfactory Roller. The construction consists of three heavy steel plates, pressed together and electric-welded, forming one solid steel drum with no leaky joints; handles are securely attached as shown in the illustration. A scraper keeps the Roller clean. It is easy to pull. The drum rounded edges to avoid tearing the turf. The Roller is filled with either water or sand, and by using more or a weight is obtained which is most suitable for the conditions-light for moist lawns, medium for dry lawns, heavy for paths. The weight of each Roller empty and filled is given with the diameter and length below.

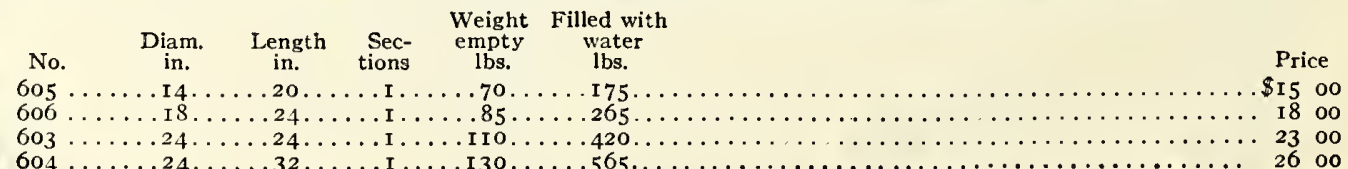

\section{Cast-Iron Hand Lawn Rollers}

Made in one, two, and three sections. The face of each Roller is made smooth, with outer edges rounded to avoid cutting the lawn or garden. The Rollers of two or more sections are preferable, as they will not injure the grass when turning. The best one-man Rollers are those averaging from $300 \mathrm{lbs}$. to $45^{\circ} \mathrm{lbs}$.

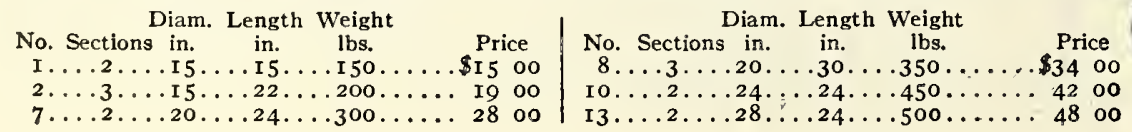

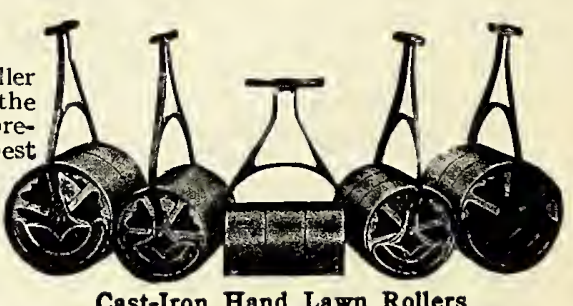

Cast-Iron Hand Lawn Rollers 


\section{Pruning Tools, Orchard Supplies, Rubber Hose, Etc. PRICES SUBJECT TO MARKET CHANGES}

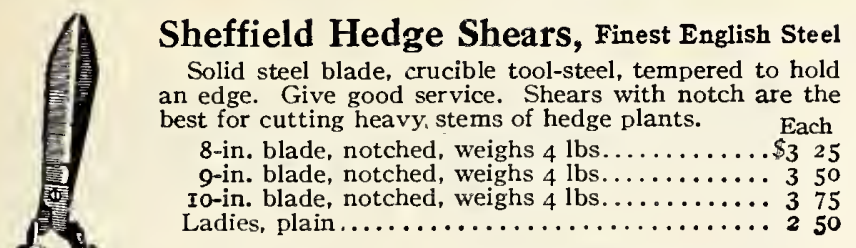

\section{S. \& W. Co.'s Grass Shears}

A very simple but practical locking device holds the Shears together. Made of the b e s t cruc'ble tool steel; polish finish. Hedge

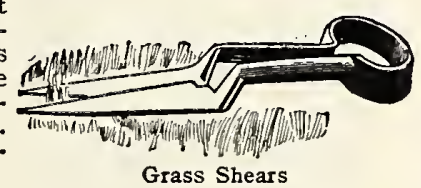

Western Grass Shears. Made of good-quality tool-steel. A onepiece Shears. Plain finish, 6-in. blade, \$1.50.

\section{Pruning Shears}

S. \& W. Co.'s Solid Steel. Crucible tool-steel. Blade and handle are one piece of polished steel; a ratchet nut keeps the Shears properly tightened; will not break; excellent finish. Made in three sizes. 8 -in. $\$ 3.25 ; 9$-in. $\$ 3.50$; I0-in. $\$ 3.75$.

Sawco. Made of high quality steel. A very good Shears for grapevines and shrubbery. \$1.50.

Ladies' Nickel-plated. Light, practical, handy to use on roses and shrubbery. $61 / 2$-in. $\$ 2.50$.

\section{Hose Couplings}

Regular. $1 / 2$-inch, 15 cts., $3 / 4$-inch, 20 cts. ea.

\section{Hose Menders}

Cooper's Brass. $1 / 2$ and $3 / 4$-inch, ro cts

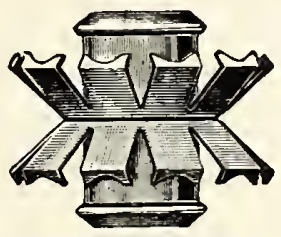
each, \$I per doz.; I-in., I5 cts. each, Perfect Clincher Mender $\$$ I.5O per doz.

Perfect Clincher. $1 / 2$ or $3 / 4$-inch, I5 cts. each, $\$ 1.50$ per doz.

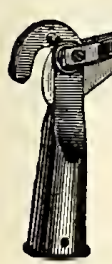

Telegraph Pole

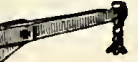

\section{Telegraph Pole Pruner}

Facilitates the pruning of tall trees, eliminating the danger incident to using a ladder. It is very strong and durable. Plain, \$1.75; with handle, \$2. Extra knives, $40 \mathrm{cts}$. each; extra springs, $40 \mathrm{cts}$. each.

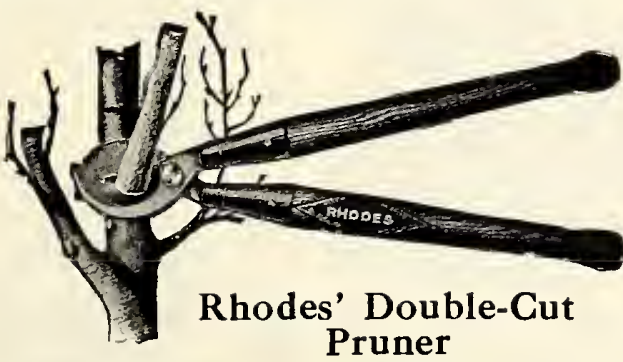

A good and powerful Pruner. Cuts from both sides of the limb, and does not bruise the bark. Long ferrules; handles do not pull out; blades are of the best forged steel. 30 -inch, $\$ 5 ; 36$-inch, $\$ 5.25$.

\section{Asbestos Torch}

Attach the Torch to the end of a pole; saturate with kerosene oil, light and hold under the caterpillars' nests, and pass quickly along the branches and around the trunk of the tree. The heat instantly destroys the insects and will in no way injure the trees. Without pole, 60 cts.

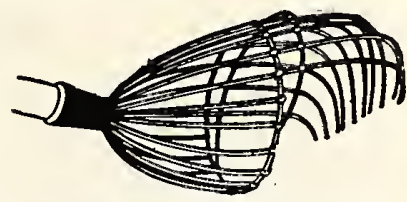

Perfect Fruit-Picker

Made of steel wire, heavily galvanized; can be attached to any pole. $60 \mathrm{cts}$. each.

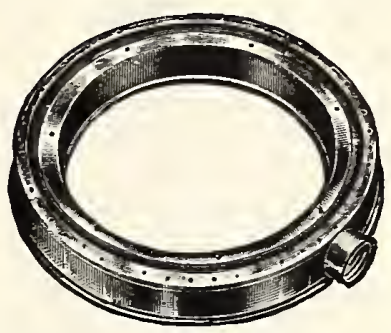

\section{Ring Lawn Sprinkler}

The S. \& W. Co.'s Ring Sprinkler is not to be compared with the cheaper Ring Sprinklers. It is made of brass, firmly constructed, and guaranteed to stand the water-pressure of any municipal waterworks in the United States. 9o cts.

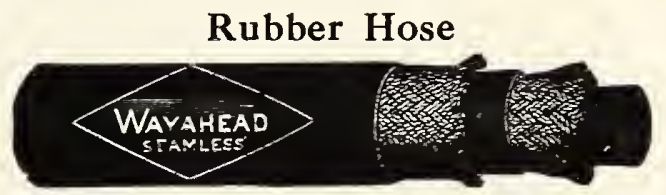

S. \& W. Co.'s Special Brand (Wayahead). Surpasses all the cheaper grades of Hose. Its durability is not excelled by much of the higher-priced Hose. It is three-ply, seamless, and non-kinkable Standard lengths, $3 / 4$-inch bore, $25 \mathrm{ft}$., $\$ 4.50 ; 50 \mathrm{ft}$., $\$ 8$; Ioo ft. $\$$ I5.

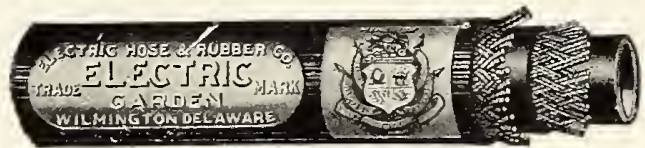

Electric. Three-ply, non-kinkable, molded Hose. The strength and durability of this Hose place it with the very best grades of Hose manufactured.

Standard lengths, $3 / 4$-inch bore, $25 \mathrm{ft}$., \$6.25; $50 \mathrm{ft}$., \$I2. Standard lengths, $1 / 2$-inch bore, $25 \mathrm{ft}$., $\$ 5.75 ; 50 \mathrm{ft}$., \$10.50.

5 lengths or more of 50 feet, $3 / 4$-inch bore, 23 cts. per $\mathrm{ft}$.

5 lengths or more of 50 feet, $1 / 2$-inch bore, $20 \mathrm{cts}$. per $\mathrm{ft}$.

Justrite Spray Nozzle. A very popular adjustable Nozzle. It gives a copious spray or a well-defined full stream. Has a positive shut-off, by turning the barrel of the nozzle. $60 \mathrm{cts}$.
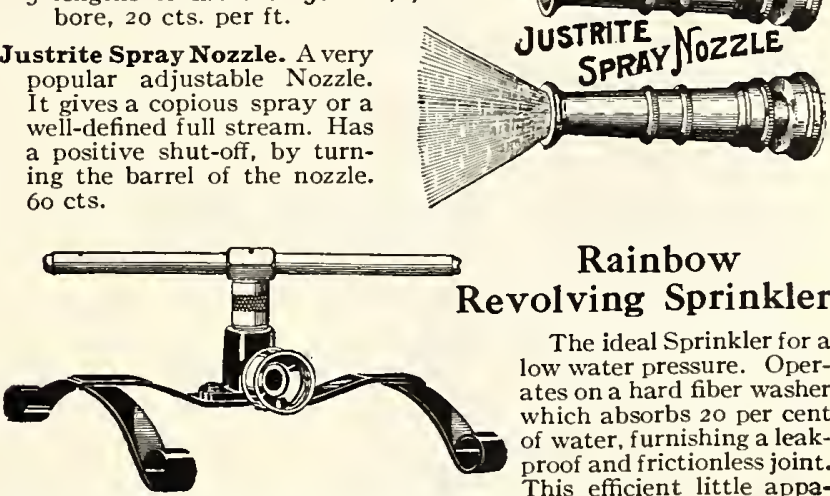

\section{Rainbow} Revolving Sprinkler

The ideal Sprinkler for a low water pressure. Operates on a hard fiber washer which absorbs 20 per cent of water, furnishing a leakproof and frictionless joint. This efficient little apparatus has proven through actual tests to deliver the maximum amount of spray on a low pressure; no wear and tear. Will water a circle of 40 to 50 feet in diameter. Price $\$ 2.50$.

\section{Mole Traps}

Schroeder Improved No. 1. It has a rest on top for a weight, also eight sharp prongs and a strong spiral spring. \$2.50 each, \$25 per doz.

The Rittenhouse. The simplest, safest, and surest mole trap ever invented. Self-setting. No danger of its going off unless the trigger is touched. Made of all steel and tinned. Six in a crate. The spears are spring steel, therefore not so long as soft steel. \$I.IO each, \$I I per doz.

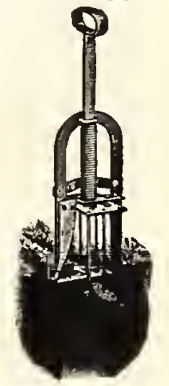

Rittenhouse 


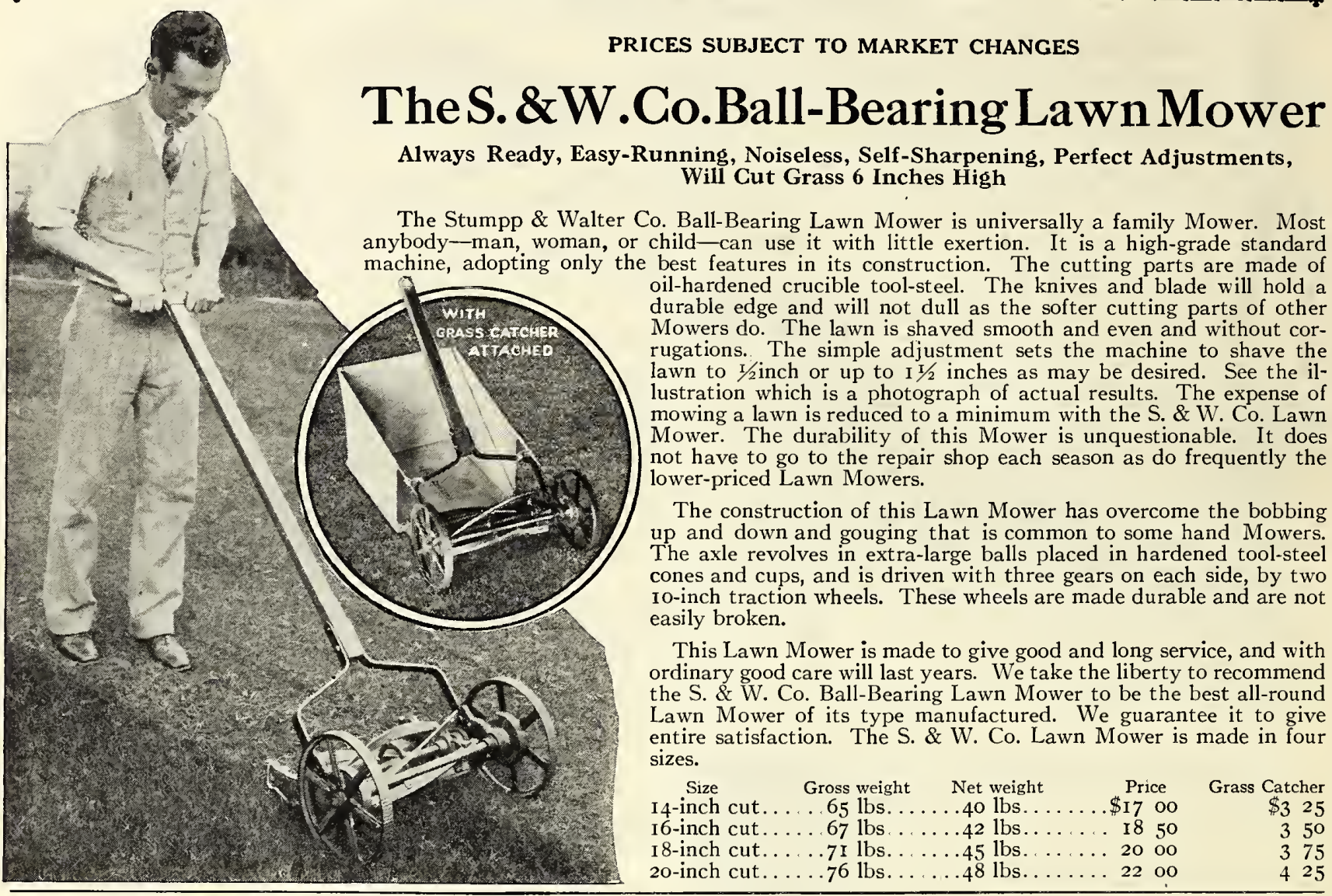

\section{Four-Acre Heavy Duty Power Lawn Mower}

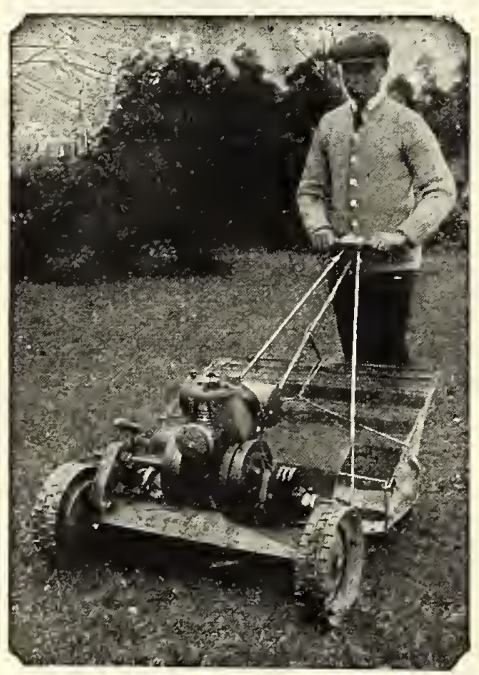

Four-Acre Heavy Duty Lawn Mower 24-inch Cut

\section{THE PINNACLE OF PERFECTION IN HEAVY DUTY POWER MOWERS}

THE FOUR-ACRE HEAVY DUTY MOWER is a powerful grass-cutter, sturdy as a tractor-the handiest and most economical Power Mower on the market. Performance is the standard by which Power Mowers are judged, and in this respect the Four-Acre Heavy Duty is in a class of its own. THE MOTOR is specially designed, air-cooled, has forced-draft and throttle control; starts easily, is powerful and reliable.

INDEPENDENT CONTROL of power on cutting unit and traction allows it to travel over stony roadways, up and down curbings, etc., without revolving cutting unit. In case any sticks or stones become caught in the cutter blades, the reel clutch will slip, leaving knives uninjured.

Price $\$ 295$, f. o. b. Baltimore. Grass Box, $\$ 6$ extra

\section{Heavy Duty Sulky}

With the use of this attachment the driver is able to cover 6 to 7 acres per day instead of 4 . Sulky only, \$45 extra. Mower, with Sulky, $\$ 340$.

\section{Two-Acre Junior Lawn Mower (19-INCH CUT)}

Designed especially for moderate-sized lawns and lawns broken up with numerous obstructions. Cuts 2 acres a day on less than I gallon of gasoline at a speed which may be varied from 2 to $2 \frac{1}{2}$ miles per hour. Has a four-cycle $3 / 4-h$. p. motor. The cutter has five blades, is 19 inches in length. and may be adiusted to cut the grass from $1 / 2$ to $I / 2$ inches. Durable and efficient, fully guaranteed. Mower with traction clutch only, $\$ 210$, f.o.b. Baltimore. Grass Box, $\$ 5$ extra.

\section{Townsend Flyer Mower}

The best low-priced Mower made with ball-bearings. Four revolving blades, flexible bottom knife, self-sharpening. Made of best materials. A very easy-running and light Mower for ladies and children to operate Price Grass Catcher

I 2 -inch cut........... \$10 oo

I4-inch cut.

II 00

$\$ 3$ o0

I6-inch cut.
I 8 -inch cut.
Price

\$I 200

I3 00
$\$ 350$ 375

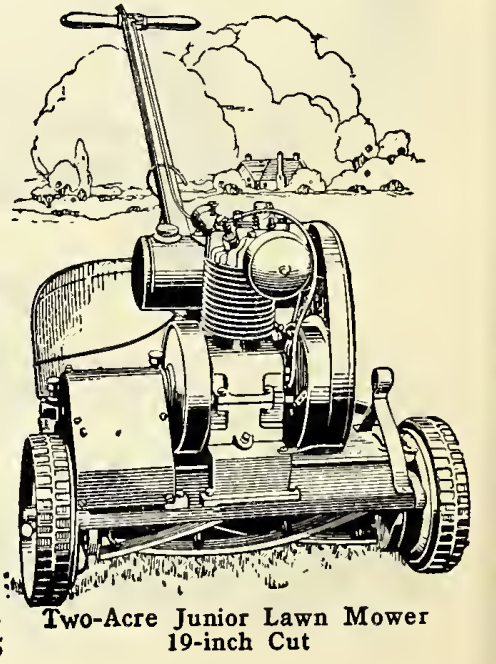




\section{Little Books of Great Value at Popular Prices}

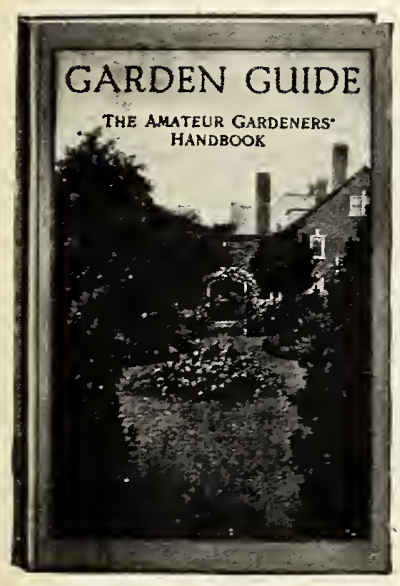

The Gem of Gardening Literature. 384 pages. Size $71 / 4 \times 5$ inches. Illustrated. $\$ 1$.

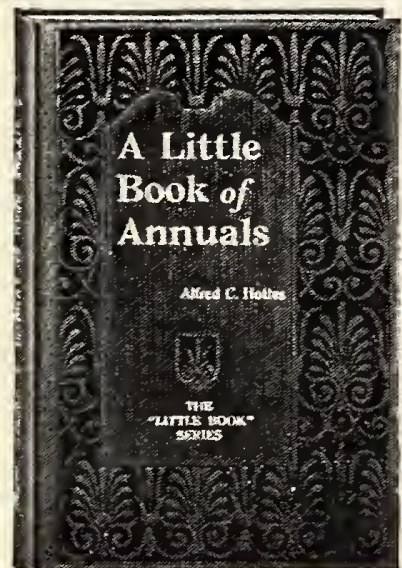

One hundred species are described with full directions for their culture. $\$ \mathbf{1 . 5 0}$

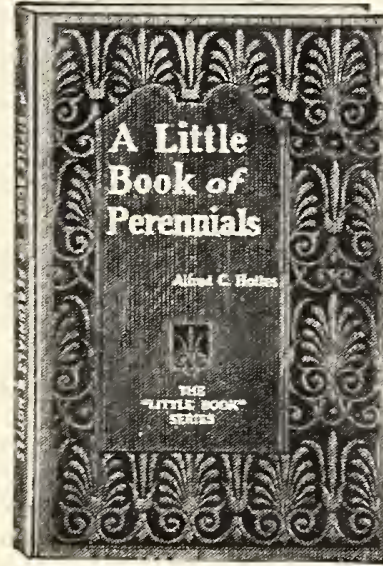

Devoted to the general principles of propagating perennials. \$1.

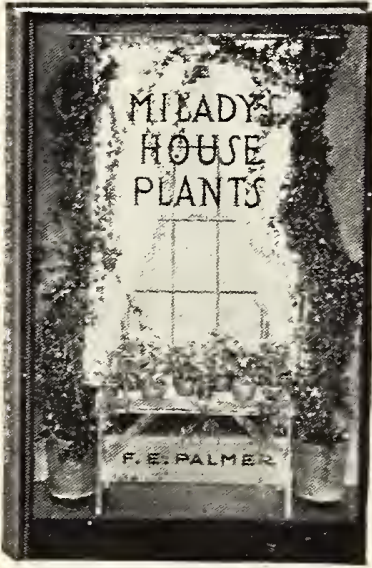

Tells of the plants any woman can successfully grow indoors. $\$ 1.25$

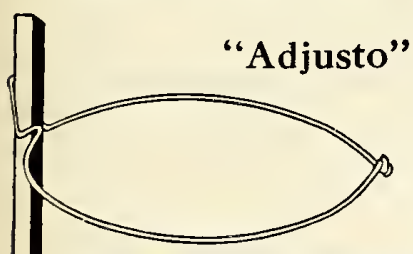

\section{Watering Pots}

We offer a special line of strongly made pots in heavy gauge galvanized iron. Note the solid spout; this, with the dome top, makes these pots the strongest made. The nose is attached firmly to the spout with a screw joint, and the cap is removable to permit of cleaning. These compete in price with the cheaper pots now on the market. 6-qt. \$I.Io; Io-qt. \$1.50; I6-qt. \$2.

air and sun, and from the ground. Enables you to tivate close to the plant. "Adjusto" supported tomatoes ripen to perfection. "Adjusto" supports bring out the full beauty of dahlias, chrysanthemums, and all the slender, tall-growing varieties.

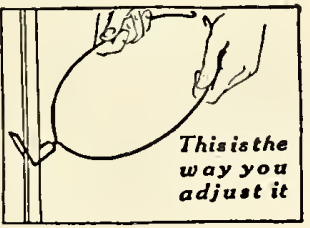

\section{Bird-Houses}

Encourage the birds; they are your friends. They have a keen appetite for grasshoppers, grubs, beetles, flies, and other pests. It is said that if all birds were suddenly to perish there would not be a leaf, a blade of grass, or any green thing left upon the earth within a few years

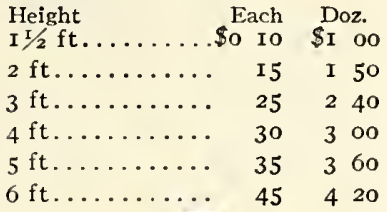

-it would be uninhabitable. The presence of birds in the garden should indeed be welcome. You can easily find places for bird houses on your fences and trees and we can offer same as follows:

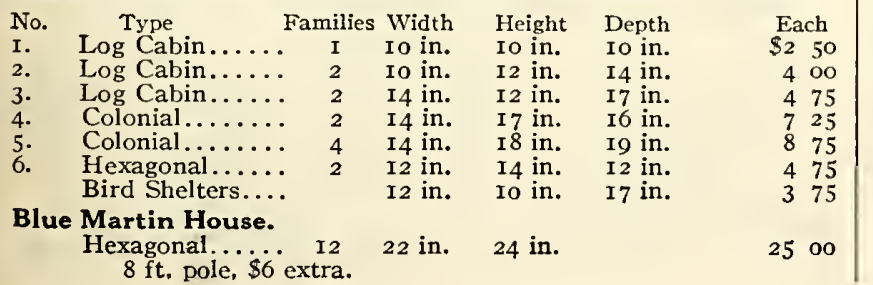

\section{Haw's Pattern.}

No. o, 2-quart

No. I, 3-quart

No. 2, 4-quart

No. 3, 6-quart

No. 4,8 -quart ....... 8 oo
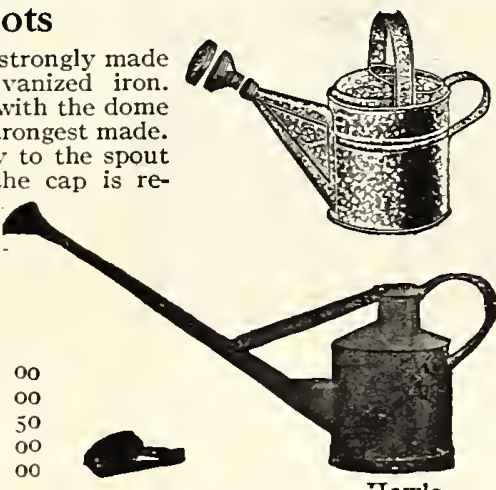

\section{S. \& W. Co.'s Double-Barrel Dust Gun}

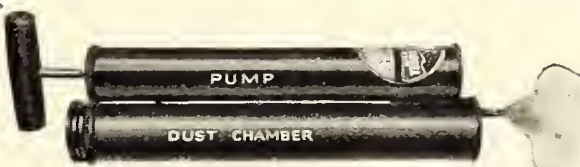

A simple device for applying dry powder insecticides and fungicides without waste and with the least possible effort. It blows the powder onto the plants. Insecticides which may be applied economically with this Dust Gun include hortex, tobacco dust, bug death, hellebore, Paris green, arsenate of lead, etc.; fungicides which may be used with it are Semesan, bordeaux powder, grape dust, powdered sulphur, etc. 'rice go cts.

\section{TRELLISES}

Made of wood and rattan painted green. The most durable and ornamental trellis on the market.

If crating is required for express or freight shipments, same will be charged at cost.

\section{Veranda Trellises}

Ornamental and substantial. Especially adapted to outdoor use for high climbing plants. Each Doz. Each Doz. $16 \times 1 / 2 \mathrm{ft} \ldots \$ 3$ oo $\$ 33$ oo $2 \mathrm{ft} . \ldots .$. \$I IO \$I 2 oo $8 \times$ I I I 2 ft. 4 oo 44 oo $3 \mathrm{ft} . \ldots . .$. I 50 16 oo $10 \mathrm{x}_{12} 2 / 3 \mathrm{ft} . .5$ oo 55 oo $\begin{array}{lllllllll}4 \mathrm{ft} . \ldots \ldots & \text { I } 85 & 20 & \text { oo } & \text { I } 2 \times 2 \mathrm{ft} . \ldots .6 & 60 & 66 & 00\end{array}$

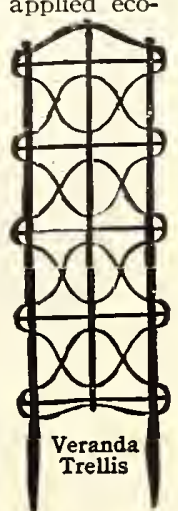




\section{Sprayers for Applying Insecticides and Fungicides}

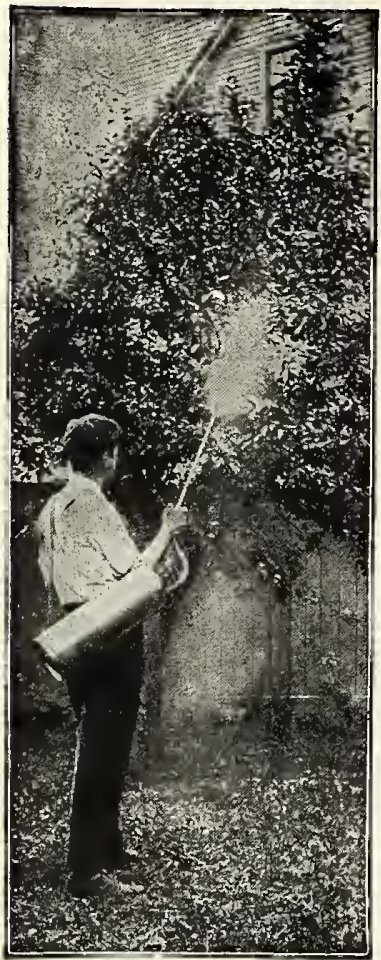

\section{Super Auto Spray}

No. Ioo Auto-Spray is made of extra-heavy metal to hold up under a pressure of roo pounds, the pump is of small bore, so that this pressure can be pumped with little exertion. Handles and collar are very heavy brass, and the strap is adjustable and of the best of material. It is double riveted and specially soldered and tested carefully. The large capacity, extra-high pressure, extra strength, and beautiful appearance make it a super auto spray, and, as the name implies, is 100 per cent.

Tank made of galvanized steel or brass. High-grade hose. Castings for handle, etc., all malleable. No continuous pumping as in the case of the Knapsack Sprayer, nor continuous pumping or slopping as in the case of the bucket pump. A few strokes of plunger compresses enough air to cover a quarter acre of potatoes or similar crop. Extension pipes useful for spraying tall trees. Detailed descriptive circular on request.

Auto-Spray No. IooB. Brass Tank, with "Auto-Pop" and one

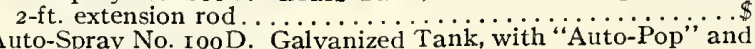
one 2 -it extension rod.................... 725

Two-row Attachment for spraying two rows at one passing.... I 50 2-foot Brass Extension Pipe..

18-1n. Brass Extension Rod-45-degree

Brass Elbows for spraying unoer vines.

Torch .

Brass Strainer for straining solution.

Auto-Spray Nozzle. .

\section{S. \& W. Co.'s Fruitall Spray Pump}

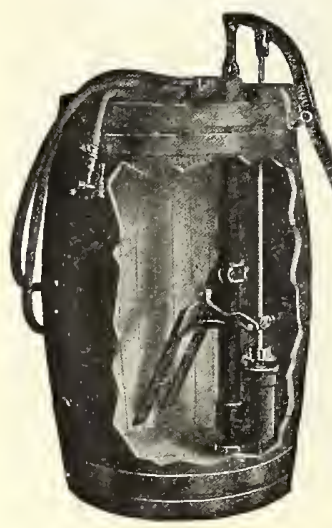

The "Fruitall" illustrated herewith has been designed especially to meet the demand for a low-priced Sprayer combining the necessary durability, efficiency, and strength.

Outfit C. Sprayer with agitator and one lead of 15 feet $1 / 2$-inch discharge hose, with "Mistry Jr." spray nozzle. Price, without barrel, $\$ 21.50$

Outfit D. Sprayer with agitator and two leads, I5 feet each, $1 / 2$-inch discharge hose, with "Mistry Jr." spray nozzle. Price, without barrel, $\$ 28.50$

We supply barrel, and mount sprayer on it, for $\$ 7.50$ extra, but the barrel is not furnished unless speci. ally ordered.

\section{A Reliable Thermometer}

Coppered tin case; distance reading. Black oxidized brass scale, white figures. (Spirit.) Scale range, r20 degrees above to 40 degrees below zero. 8 -inch, 85 cts.

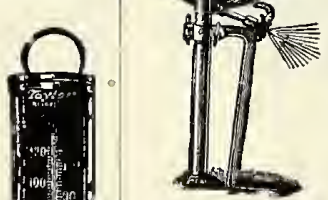

\section{Double-Acting Pump Sprayer and Knapsack Tank \\ THE SAME SPRAY WITH HALF THE LABOR}

Pump.-This Pump is the ideal all-purpose sprayer. Its field is practically unlimited, as it may be used for spraying trees, vines, garden truck, potatoes, and any field crops. Made entirely of brass, doing away with all danger of corrosion. This Pump is double-acting, which gives a continuous spray, a distinct advantage over single-acting Pumps in that the pump works on both the up and the down stroke. The Pump cylinder is small in diam.

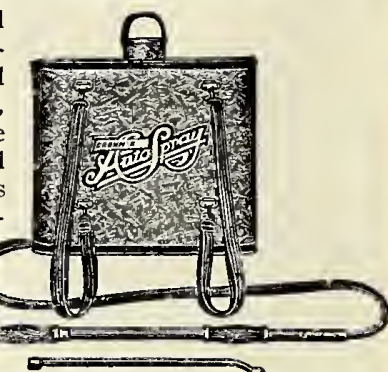
eter, and in a test a pressure of 180 pounds to the square inch was raised with very little labor.

Knapsack Tank.-Where a portable tank for field or garden work is needed, we recommend our patrons purchasing the Knapsack Tank as well as the Pump.

\section{OUTFITS AND EQUIPMENT}

Double-acting pump, with $21 / 2$ feet of $1 / 2$-inch suction hose, nozzle, and strainer, complete.................... $\$ 5$ oo Knapsack galvanized-iron tank, for field or garden work..... 350 Extension rod, curved, brass.

Two-row attachment of solid brass, for spraying two rows at a time............................ I 50

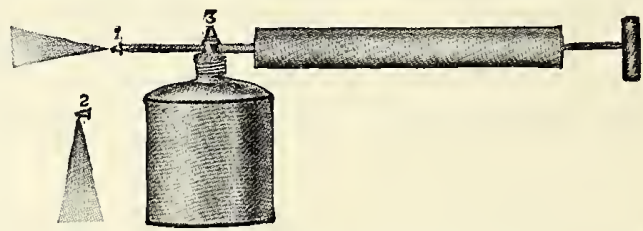

\section{S. \& W. Co.'s Compressed Air Sprayer}

Will handle all solutions, insecticides, and disinfectants. Used in the greenhouse, kitchen-garden, window-garden, for rose bushes, and in the poultry-house. Two spray caps-one straight, the other at an angle for reaching under leaves or spraying directly down. Construction of tank permits the Sprayer to be operated at any angle,

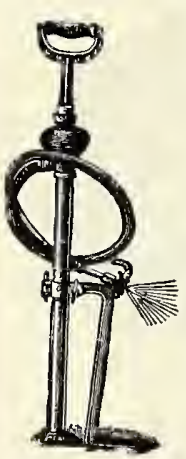
and it will not tip over when filling. All tin, $85 \mathrm{cts}$; tiı pump, galvanized tank, $\$ 1.25$; all brass, $\$ 2.25$. Weight, 2 lbs.

\section{S. \& W. Bucket Spray Pump}

The S. \& W. Spray Pump is a saving in the cost of small hand Sprayers. It is a quality Sprayer. This Pump is made of heavy seamless brass tubing, with a large brass air-chamber; it has brass ball valves, is double-acting and will produce a continuous spray or stream. A bordeaux nozzle, with 3 feet of $1 / 2$-inch spray hose is furnished. The nozzle can be regulated to throw a very fine, medium or coarse spray. We recommend this Sprayer as the best cheap hand Sprayer for applying whitewash, coldwater paint and disinfectants. When ordering Sprayer to be sent by parcel post, allow for Io lbs., the packed weight of Sprayer. $\$ 6.50$

Bellows, Woodason's Powder, small size........\$3 50 " large size........ 475 Liquid, small size......... 4 25 large size....... 475

Double-Cone Powder Bellows. For dusting plant with dry powders for insects and fungus. $\$ 7.25$.

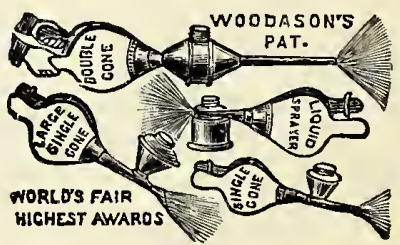




\section{REMEDIES FOR INSEGTS AND FUNGUS}

NOTE.-Insecticides marked * can be sent by Parcel Post at purchaser's expense. Consult your local post office for rate from Baltimore, Md.

\section{ALL PRICES SUBJECT TO MARKET CHANGES}

Antrol. A complete Ant-Control System consisting of special vatented glass containers and Antrol Syrup, U. S. Government Formula. Cottage Set contains nine receptacles and six-ounce bottle of syrup, sufficient to fill them the first time and control ants around a five or six-room house. Cottage Set \$I.9o. Extra Syrup, pt. bottle \$I, gal. can $\$ 4$.

Arsenate of Lead, Powdered. A strong poison for killing bugs on fruits and vegetables. Especially fine, light, and fluffy. Use either as a dust or liquid spray. $1 / 2-\mathrm{lb}$. carton $25 \mathrm{cts}$., I-lb. carton $50 \mathrm{cts}$., 5 -lb. bag $\$ 2.00,25$-lb. bag $\$ 8$, I00-1b. drum $\$ 24$.

Black-Leaf 40. A concentrated solution of nicotine sulphate; an excellent spray for black aphides and sucking insects of all kinds. Dilutes one part to 900 or $\mathrm{I}, 000$ parts of water, according to treatment. Full directions on each package. I-Oz. bottle $35 \mathrm{cts}$. $1 / 2-1 b$. tin $\$ 1.25,2$ lbs. $\$ 3.25$, Io lbs. $\$ 11.85$.

Bordeaux Mixture, Dry Powder. Used when only a fungicide is required to control blights, rusts, and rots on vegetables and small fruits. It carries no poison for bugs or worms. $1 / 2 \mathrm{lb} .25 \mathrm{cts}$. I-lb. pkg. 40 cts., 5-lb. bag $\$$ I. $50,25-1 b$. bag $\$ 5.75$.

*Climax Lawn Sand. A combination of carefully dried and finely ground chemicals. Destroys weeds. $31 / 2$-lb. can 65 c., 7 -lb. can $\$ 1.25$ I 4 -lb. can $\$ 2,28-\mathrm{lb}$. pkg. $\$ 3.75,56-\mathrm{lb}$. pkg. $\$ 7.25$.

Fish-Oil Soap. For mild forms of scale; is an excellent summer spray, when something stronger cannot be used, where the San Josê scale exists. It is good for washing off lemon trees, oleanders and almost anything that would be infested with a soft-shelled or in fact almost any kind of insect. Lb. 25 cts., 5 lbs. \$I.IO, Io Ibs. $\$ 2,25$ lbs. \$4, I oo lbs. \$I 3 .

* Grape Dust. For mold, mildew, or rust-mites, either in the greenhouses or open air. 5 lbs. 85 cts., Io lbs. $\$ 1.60,25$ lbs. $\$ 3.75$.

Hellebore, Powdered. Good for exterminating currant worms. $1 / 2$ lb. 30 cts., lb. 55 cts., 5 lbs. $\$ 2.50$.

Kayso. A combined casein spreader and adhesive. Its use keeps spray from washing off and reduces arsenical injury. Kayso makes all spray solutions more effective. Use I tablespoonful Kayso to 5 gallons of solution or $\mathrm{I}^{1 / 2}$ pounds to 200 gallons. $8-\mathrm{oz}$. can $30 \mathrm{cts}$. 2 lbs. 80 cts., Ioo lbs. $\$ 30$.

Kerosene Miscible Oil. For plant lice and other soft-bodied insects, especially woolly aphis; also for rose bugs, cabbage worms, scale, and melon louse. Contains 80 per cent kerosene. Dilutes I part to 25 parts of water. Pt. 50 cts., qt. $90 \mathrm{cts}$., gal. \$2, 5 gals. \$9.

Lemon Oil. Odorlcss and poisonless; i to 30 to 40 parts of water. Destroys mealy bug, scale, thrips, red spider, black and green fly, caterpillar, etc. 1/2pt. 45 cts., pt. 75 cts., qt. $\$ 1.25,1 / 2$ gal. $\$ 2.25$. gal. $\$ 3.75$.

Liquid Weed Killer, Herbicide. There is nothing more annoying to the well-kept home grounds than weeds constantly coming up in the roadways, paths and gutters. The Weed Killer may be applied by means of a sprinkling apparatus of any kind from the small sprinkling can to the large street-sprinkling wagon. It is harmless to stone, woodwork, or shoes and is perfectly odorless. One thorough application will kill all weeds as well as the roots of the same. Qt. 70 cts.. 1/2gal. \$r.20, gal. \$2, 5-gal. keg \$8, I0-gal. keg $\$_{15}, 30$-gal. cask $\$ 33,50$-gal. bbl. $\$ 50$.

Lime-Sulphur, Bowker's Concentrated. Destroys San José scale. Manufactured under the direct personal supervision of skilled graduate chemists who have devoted years to manufacturing spraying materials. I-qt. can $50 \mathrm{cts}$., I-gal, can $\$ 1.25,5$-gal. can $\$ 4,1 / 2$ bbl. (about 25 gals.) \$10.50, bbl. (about 50 gals.) \$1 5 .
Mag-o-Tite. Insures a good crop of radishes, kale, cabbage, onions turnips, cauliflower, etc. You can now sow any of these crops and be certain of protection against the destructive root maggot, earthworm and other pests. 2 -lb. pkg. $40 \mathrm{cts}$., 4 -lb. pkg. $70 \mathrm{cts}$., $8+1 \mathrm{~b}$, pkg. \$1.25.

Nico-Fume Liquid. This preparation is a free nicotine preparation, and is used by many of the leading growers. $1 / 4-\mathrm{lb}$. can $75 \mathrm{cts}$., lo. can $\$ 2,4$-lb. can (1/2-gal.) $\$ 6.25,8$ lbs. (gal.) \$II.50.

*Nico-Fume Paper. This is a paper treated with nicotine, giving off dense fumes of strong nicotine when ignited. It is also used for tying near blooms of chrysanthemums in early fall to keep down insects. Preferred by many who do not wish to spray or vaporize. Box of 24 sheets, \$I.25, box of I 44 sheets $\$ 5$, box of 288 sheets $\$ 8.75$.

Para-Dichlorobenzene. Highly recommended for destroying the peach borer in trees four years and older. During September a ring of the crystals is placed on the soil around the trunk and covered by mounding the earth against the tree. One ounce is sufficient for each tree. Lb. 75 cts., 5 lbs. $\$ 2.75$, Io lbs. $\$ 5$.

Paris Green. I/4lb. I 5 c., $1 / 2 \mathrm{lb}$. 30c., lb. $55 \mathrm{c}$., 5 lbs. $\$ 2.50$, I 4 lbs. $\$ 5$.

Pyrox (Bowker's). The one best and safest all-round spray which kills all leaf-eating insects and prevents blights and all fungous troubles, without injury, on fruit trees, grape-vines, currant bushes, potatoes, cantaloupes, cucumbers, and other garden vegetables. also on rose bushes, shrubbery, etc. It is a creamy paste which looks like paint and "sticks like paint." It needs only to be mixed with cold water and it is ready to apply. Once tried, alway's used. Lb. 50 cts., 5 lbs. \$I.75, Io lbs. \$3-I 5, 25 lbs. \$6.50, 50 lbs. \$ I I.25, Ioo lbs. \$I 8,300 lbs. \$.5

Semesan is a seed disinfectant. Dusting the seed with it protects against fungus and disease. 2 ozs. 50 cts., $1 / 2 \mathrm{lb}$. $\$$ I. $60,1 \mathrm{~b} . \$ 2.75$, 5 Ibs. \$I3.

Slug-Shot. The standard remedy for currant worms, rose slugs, cabbage worms, and almost any soft-shelled insects that infest the garden. Lb. 25 cts., 5 lbs. 75 cts., Io lbs. \$I.20, I $25^{-1 b}$. keg \$I 2.50 ,

Snarol. For the control of cutworms, snails, slugs, etc. Noninjurious to vegetation and very economical because of its insolubility in water, thereby rendering it effective for one to three weeks. Lb. 50 cts., 3 lbs. \$I, I5 lbs. $\$ 3.75$

*Sulphur. Used principally in greenhouse for checking mildew. Lb. 25 cts., 5 lbs. \$I, Io lbs. \$I.60, I0o lbs. \$I 2 .

Tobacco Dust (Kilmdead). The best of the Tobacco Dusts for dusting or fumigating. Lb. 25 cts., 5 lbs. 75 cts., 25 lbs. $\$ 2$ 50 lbs. $\$ 3.50$, I 00 lbs. $\$ 6$.

Tree Tanglefoot. A paste preparation for painting around the trunks of trees, in the form of a band. Caterpillars and other crawling pests cannot gct over it. Lb. 60 cts., 5-Ib. can $\$ 2.75$, Io-lb. can $\$ 5.25,25$ lbs. SI I.

Tree Wound Paint. Prevents decay. A residuum, penetrating, antiseptic paint that is not affected by heat, cold or moisture. Does not peel, crack or get brittle. Stops tree bleeding. Pt. 60 cts., qt. SI, gal. \$3, 5 gals. \$I 2

Volck. A spray for scale insects, mealy bugs, white flies, red spiders rust mites, and similar insects. $1 / 2$ pt. $50 \mathrm{cts}$., pt. $75 \mathrm{cts}$., qt. $\$ \mathrm{I}$, gal. $\$_{3}, 5$ gals. $\$_{12} .50$, I 4 gals. $\$ 25,28$ gals. $\$ 40$.

Wilson's O. K. Plant Spray. For roses, chrysanthemums, evergreens, and plants affected with scale or insects under glass or out side. Recommended for Rose Bugs. One part is mixed with from Io to 20 parts of water. I/2pt. $40 \mathrm{cts}$., qt. $S_{\mathrm{I}}$, gal. $\$ 3,5$ gals, \$ 12, 25-gal. bbl. \$50, 50-gal. bbl. \$9o.

\section{Crops Recommended for Green-Manuring (Cover Crops)}

Seeds broadcast thickly and the crop plowed under the land, there to decay and add humic material and fertilizing elements to it.

For early spring seeding before frosts are entirely over. Spring Vetch.........

Canada Field-Peas.

Spring Rye.

For seeding after settled warm weather has commenced. Frost kills these varieties.

Soy Beans, Mammoth Yellow

Cowpeas, New Era...

Cowpeas, Whippoorwill.

Japanese Buckwheat

For seeding during the summer and fall. These stand frost; they are sown to remain until the spring, to be plowed under then.

Winter Rye. .

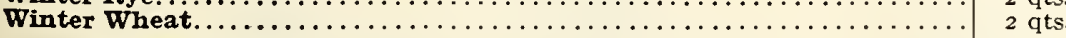

Winter or Hairy Vetch.

\begin{tabular}{|c|c|c|c|c|c|}
\hline \multicolumn{2}{|c|}{ Quantity sown } & \multicolumn{4}{|c|}{ Price, subject to market change } \\
\hline $\begin{array}{l}\text { Per Ioo } \\
\text { square yds. }\end{array}$ & Per acre & & Lb & Io lbs. & I0o lbs. \\
\hline 3 lbs. & Ioo 11 & Ot. & $\begin{array}{c}\text { So } 20 \\
\mathrm{Pk} .\end{array}$ & $\begin{array}{c}S_{\text {S } 25} \\
\text { Bus. }\end{array}$ & $\begin{array}{l}\text { Sio oo. } \\
\text { Io bus. }\end{array}$ \\
\hline $\begin{array}{l}3 \mathrm{qts} . \\
2 \mathrm{qts} .\end{array}$ & $\begin{array}{l}3 \text { bus. } \\
2 \text { bus. }\end{array}$ & So 30 & $\begin{array}{rr}\text { SI } & 50 \\
\text { I } & 25\end{array}$ & $\begin{array}{rr}S_{5} & 25 \\
3 & 75\end{array}$ & $\begin{array}{r}\$ 50 \\
3500 \\
35\end{array}$ \\
\hline $2 \mathrm{gts}$. & 2 bus. & 25 & I 35 & 400 & 3750 \\
\hline 2 qts. & 2 bus. & $3 c$ & I 50 & 450 & 4250 \\
\hline $2 \mathrm{qt}$ & 2 bus. & 30 & I 50 & $45^{\circ}$ & 4250 \\
\hline 2 qts. & 2 bus. & 20 & $9^{\circ}$ & 3 oo & 2750 \\
\hline 2 qts. & 2 bus & 25 & I oo & 325 & 3000 \\
\hline $2 \mathrm{qt}$ & 2 bus & 25 & I 35 & 425 & 4000 \\
\hline 3 lbs. & Ioo lbs. & & So 35 & $\$ 3$ oo & $\$ 2500$ \\
\hline
\end{tabular}


Adco. Artificial manure is made with straw or other vegetable waste mixed with Adco the bacterial food. Is clean and repels flies. Turn your garden waste into real manure. $25-\mathrm{lb}$. bag $\$ 2.25$, I 50-1b. bag \$10.50.

Blood, Dried. Excellent for indoor culture of flowering plants, such as carnations, roses, etc. Its chief element is nitrogen. 5 lbs. 75 cts., ro lbs. $\$ 1.25,25$ lbs. $\$ 2.25$, 50 lbs. $\$ 3.75$, roo lbs. $\$ 6,500$ lbs. $\$ 27.50$, ton $\$$ I0o.

No. 2 Bone Dust for General Use. A bone dust about pinhead size, with a fair percentage of bone flour. Excellent for top-dressing lawns as well as good for mixing with soll. Sold largely to carnation and rose-growers for top-dressing and for mixing with soil. 5 lbs. $35 \mathrm{cts}$., Io lbs. $50 \mathrm{cts}$., 25 lbs. $\$$ I. $25,50 \mathrm{lbs}$. $\$ 2$, IOO lbs. $\$ 3.50$, 500 Ibs. $\$ 15$, ton $\$ 55$.

SAWCO Emerald Grass Fertilizer. A clean, portable, and convenient lawn dressing, which we have found to be never-failing in inducing a rapid and rich green growth. It should be sown broadcast in the spring or fall. It is in every way more desirable than manure. The use of Emerald Grass Fertilizer entirely does away with the old practice of top-dressing lawns with stable manure. Quantity required: A I0-lb. package is sufficient to go over an area of 300 square feet, or for forming a new lawn, from I,000 to I,500 lbs. to the acre, or a smaller quantity for renovating an old one. It is best to apply during dull weather and, if applied during warm weather, soak down with a hose after applying. 5 lbs. 50 cts. Io lbs. 90 cts., 25 lbs. $\$$ I. 75,50 lbs. $\$ 3.25$, I00 lbs. $\$ 5.50,500$ lbs. $\$ 22$, ton $(2,000$ lbs. $), \$ 75$.

SAWCO General Garden Fertilizer. This Fertilizer is for general garden work for vegetables, flowers and fruits. Io lbs. sufficient for space $15 \times$ I 5 ; 500 lbs. to the acre. 5 lbs. $50 \mathrm{cts}$., Io lbs. $90 \mathrm{cts} ., 25$ lbs. $\$$ I.75, 50 lbs. $\$ 3.25$, I0o lbs. $\$ 5.50,500$ lbs. $\$ 22$, ton $\$ 75$.

Humus. Nature's product for enriching lawns, soil for all kinds of gardening, and for stimulating potted plants. Used in making fine lawns, especially where soil is poor. 50 lbs. $\$ 2$, I0o-lb. box $\$ 3.50,5$ boxes $(500$ lbs.) $\$ 15,20$ boxes $(2,000$ lbs.) $\$ 45$.
Lime, Agricultural, Hydrated. This lime is specially prepared for use on the soil and is a combination of calcium-hydrate and calcium-carbonate, finely pulverized. Quantity required: Heavy soils, 2,000 to 6,000 lbs. to the acre; light, sandy soils, $\mathrm{I}, 000$ to $3,000 \mathrm{lbs}$. to the acre, according to their apparent need. 5 lbs. 35 cts., Io lbs. $60 \mathrm{cts}$., 25 lbs. $\$ 1.25$. I oo-lb. bag $\$ 2.75,500$ lbs. $\$ 9.50$, ton $\$ 30$. Price, delivered in carload lots to your station, upon request.

Nitrate of Soda. Quantity required: Being extremely soluble, it is usually applied after the plants are above ground, roo to 500 lbs. to the acre. I-lb. tin $25 \mathrm{cts}$., 5-lb. pkg. 75 cts., Io-lb. pkg. \$I. 25 $25-1 \mathrm{~b}$. bag $\$ 2,50-1 \mathrm{~b}$. bag $\$ 3.75$, I0o lbs. $\$ 6,500$ lbs. $\$ 25$, ton $\$ 8 \mathrm{c}$.

Sheep Manure, Pure Pulverized. A pure, natural, nutritious manure. Immediate and lasting in effect. Excellent for mixing with the soil for greenhouse plants. In the vegetable-garden it promotes a rapid, steady growth until maturity. It makes a rich liquid manure. Quantity required: For garden and field-crops, one or two tons to the acre; one-half before plowing, the balance before harrowing. For top-dressing grass, one ton to the acre, applied in fall or early spring. $5 \mathrm{lbs}$. $40 \mathrm{cts}$., 10 $\mathrm{lbs}$. $60 \mathrm{cts} ., 25 \mathrm{lbs}$. $\$ 1.25,50$ lbs. $\$ 2$, I00 lbs. $\$ 3.50,500$ lbs. $\$ 15$, ton $\$ 50$.

\section{Plantabbs}

Guaranteed to contain I I per cent nitrogen (ammonia), I 5 per cent phosphoric acid and 20 per cent potash. The ideal food for all potted plants, outdoor flowers, and vegetable gardening.

Include in your next order. Price:

Box, 30 tablets ................\$o 25

Box, 65 tablets $\ldots \ldots \ldots \ldots \ldots \ldots \ldots \ldots \ldots \ldots$ I ${ }^{50}$ Can, I,0oo tablets

\section{INDEX}

\begin{tabular}{|c|c|c|}
\hline AGE & PAGE & PAGE \\
\hline EEDS & FARM SEEDS & Euphorbia... \\
\hline sparagus.. & Alfalfa........... 8 & Four o'Clock.......... 30 \\
\hline$\ldots \ldots 2,3$ & Beans, Soy............ 7 & Gaillardia ......... 30, 43 \\
\hline$\cdots 2,3$ & Clover.: & Globe Amaranth . . . . . . 30 \\
\hline Is Sprouts. . & Corn, Fiel & $\begin{array}{l}\text { Godetia......... } \\
\text { Gourds. }\end{array}$ \\
\hline age......... & $\begin{array}{l}\text { Cowpeas. } \\
\text { Grass See }\end{array}$ & Gypsophila.......... \\
\hline$\ldots \ldots \ldots, s$ & $\begin{array}{l}\text { Grass seed . 2d co } \\
\text { Lucerne ...... }\end{array}$ & Helianthus. . . . . . . . . \\
\hline$\cdots 5$ & Mangel-Wurzei: & Helichrysum....... \\
\hline$\ldots 5$ & Millet....... & Heliotrope.......... \\
\hline$\cdots 5$ & Oats.... & biscus . . . . . . . .44 \\
\hline ( & Peas, Field. & $\begin{array}{l}\text { Hollyhock. } \ldots \ldots \ldots \ldots \ldots \ldots 44 \\
\text { Humulus. } \ldots \ldots \ldots \ldots \ldots \ldots \ldots 31\end{array}$ \\
\hline$\cdots \cdots \cdots \cdots 6_{6}$ & & Hunnemannia........32 \\
\hline $\begin{array}{ll}\cdots \cdots \\
\ldots \cdots 6\end{array}$ & FLOWER SEEI & cea........25, 26, 32 \\
\hline$\ldots 0$ & Achillea........... . 42 & chia..............32 \\
\hline .. 7 & $\cdots \cdot 42$ & \\
\hline$\ldots \ldots 6$ & $\ldots 23,42$ & ninese...30 \\
\hline$\ldots \ldots 7$ & $\begin{array}{l}\cdots 23,43 \\
\ldots .23\end{array}$ & $\cdots \cdots 3^{2}, 43$ \\
\hline$\ldots \ldots 7$ & legia...... & (a................. \\
\hline ..... I0 & $\ldots 23$ & $\ldots \ldots \ldots \ldots 33,44$ \\
\hline$\ldots \ldots$ I6 & $\ldots \ldots \ldots \ldots 24$ & $\ldots \ldots \ldots 25.33$ \\
\hline ․ 7 & $\ldots \ldots \ldots \ldots 25$ & $\ldots \ldots \ldots .33$ \\
\hline . 7 & $\cdots 42$ & .34 \\
\hline$\cdots$ & $\ldots 25$ & rdica..... \\
\hline$\ldots \ldots, 8$ & $\ldots 25$ & $\ldots \ldots 34$ \\
\hline$\ldots \ldots 8$ & $\ldots .25$ & $\ldots .35$ \\
\hline 1......... & $\cdots \cdot 4^{2}$ & .34 \\
\hline $\operatorname{tard} .$. & 26,42 & .34 \\
\hline$\ldots \ldots$ 10 & inal Climber........25 & $\ldots \ldots 34$ \\
\hline$\ldots \ldots$ Io & $\ldots \ldots 25$ & $\ldots \ldots 34$ \\
\hline . II I & $\ldots 26$ & $\ldots .36$ \\
\hline .... 10 & .26 & $\ldots 37$ \\
\hline & $\ldots \ldots 27$ & $\ldots 37,44$ \\
\hline$\ldots \ldots 12$ & $\ldots \ldots 27$ & $\ldots .36$ \\
\hline$\ldots \ldots$ I 2 & $\ldots 26$ & $\ldots .29,43$ \\
\hline$\ldots \ldots 12$ & .27 & $\cdots 30,32,35,44$ \\
\hline$\ldots \ldots 13$ & comb. . & $\ldots \ldots 36$ \\
\hline$\ldots \ldots 13$ & $\ldots 26$ & $\ldots \ldots 44$ \\
\hline & $\ldots 26$ & \\
\hline$\ldots$ I3, I 4 & & $\ldots 38$ \\
\hline$\ldots \ldots I 3$ & v., 27 & \\
\hline & & \\
\hline$\ldots \ldots \ldots$ is & $\cdots 32$ & t Runner Vine .....38 \\
\hline wedes or $\mathrm{Rl}$ & $\ldots 26$ & $\ldots \ldots 33,40,4 \mathrm{I}$ \\
\hline weet Corn.. & $\ldots 43$ & $\ldots 39,44$ \\
\hline viss Chard ..... & $\ldots \ldots 29,44$ & .....44 \\
\hline mato...... & $\ldots \ldots 29$ & bergia.. \\
\hline nip.... & $\cdots \ldots 43$ & $\cdots \cdots \cdot 4^{\circ}$ \\
\hline Vegetable Plants.. & & $\cdots \cdots \cdots 40$ \\
\hline Watermelon......... & scholtzia & innia \\
\hline
\end{tabular}

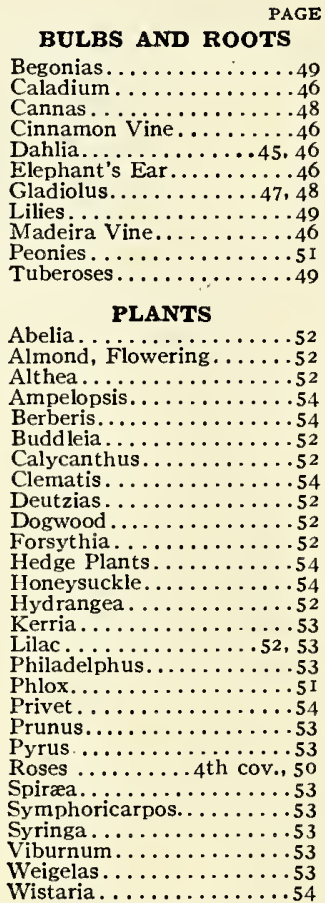

IMPLEMENTS AND MISCELLANEOUS

Barrow.

Bellows.................6. 62

Bird-Houses.

Books.............45, 53,6

Reaves and

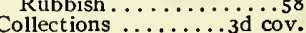

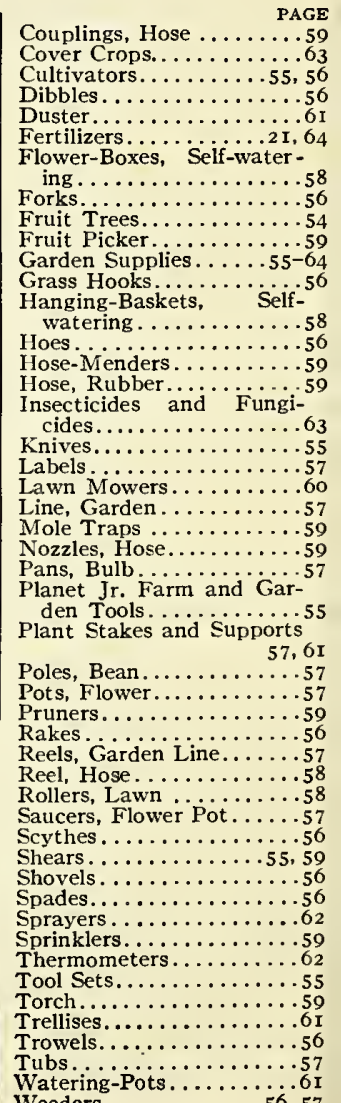




\section{ORDER SHEET}

\section{Seeds, Bulbs, Plants, Etc.}

Seed Annual, 1929

We, Stumpp \& Walter Co., give no warranty, express or implied, as to description, quality, productiveness, or any other matter of any seeds, bulbs, or plants we send out, and will not be responsible for the crop.

STUMPP \& WALTER CO. 204-206 North Eutaw Street, BALTIMORE, MD.

\section{Name \\ P. O. Box, Streel \\ or Rural Delivery}

Posl Office

Slalion or Express Office

Send by

Only if different from Post Office

Dale___ 1929

AMOUNT ENCLOSED

$\$$

SPECIAL FREE DELIVERY

See page I for conditions under

which - a I for condions under

We Prepay Transportation
Refer to the pages on which we

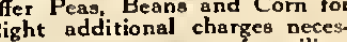
ary to cover cost of mailing.

cides, Plants and Potatoes are

shipped at purchaser's expense.

\section{Superintendenl or Gardener_}

State if wanted by Mail, Express, or Freight

That we may enter for Catalogues

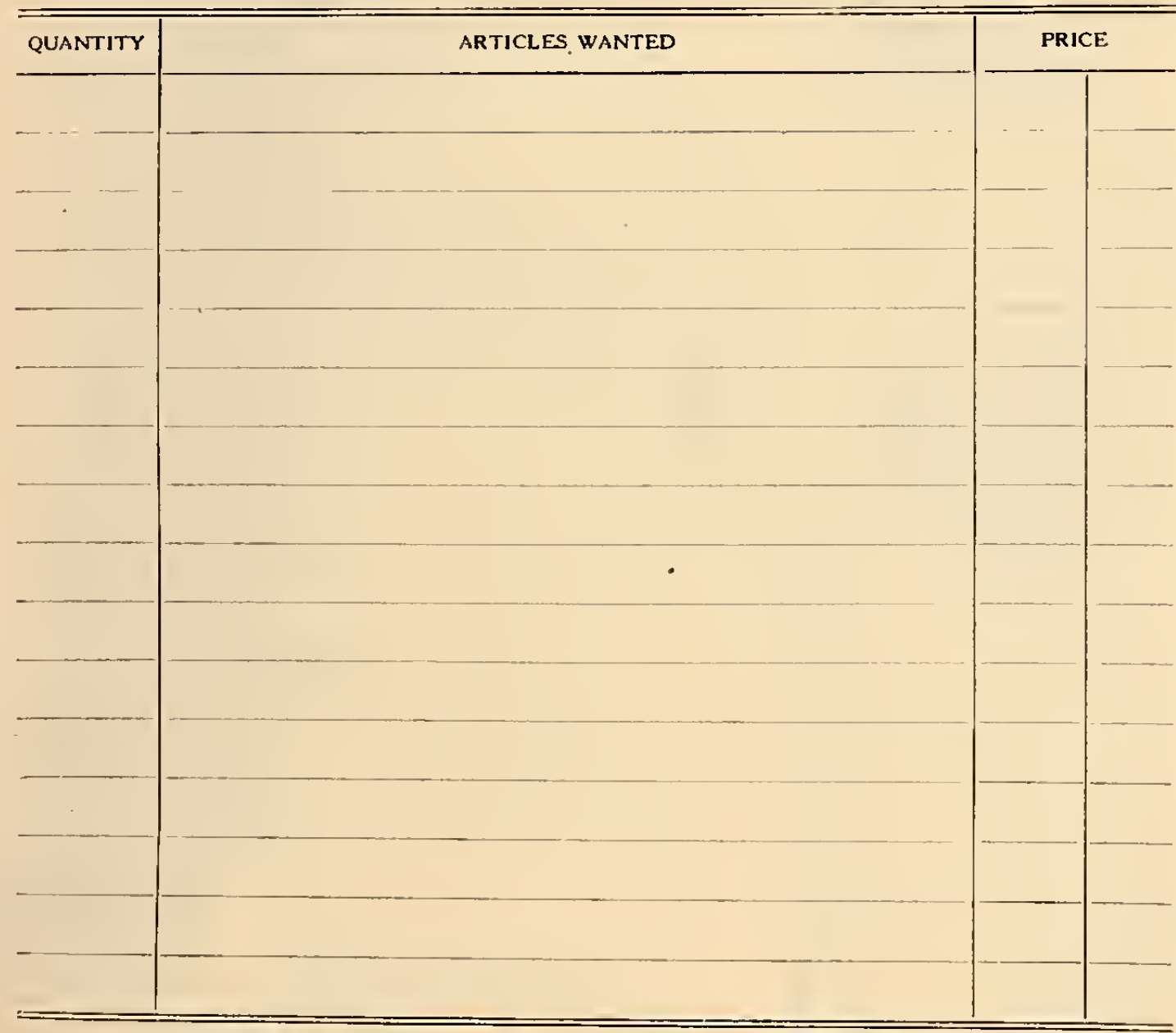

PLEASE BE SURE TO FILL IN YOUR NAME AND ADDRESS ABOVE

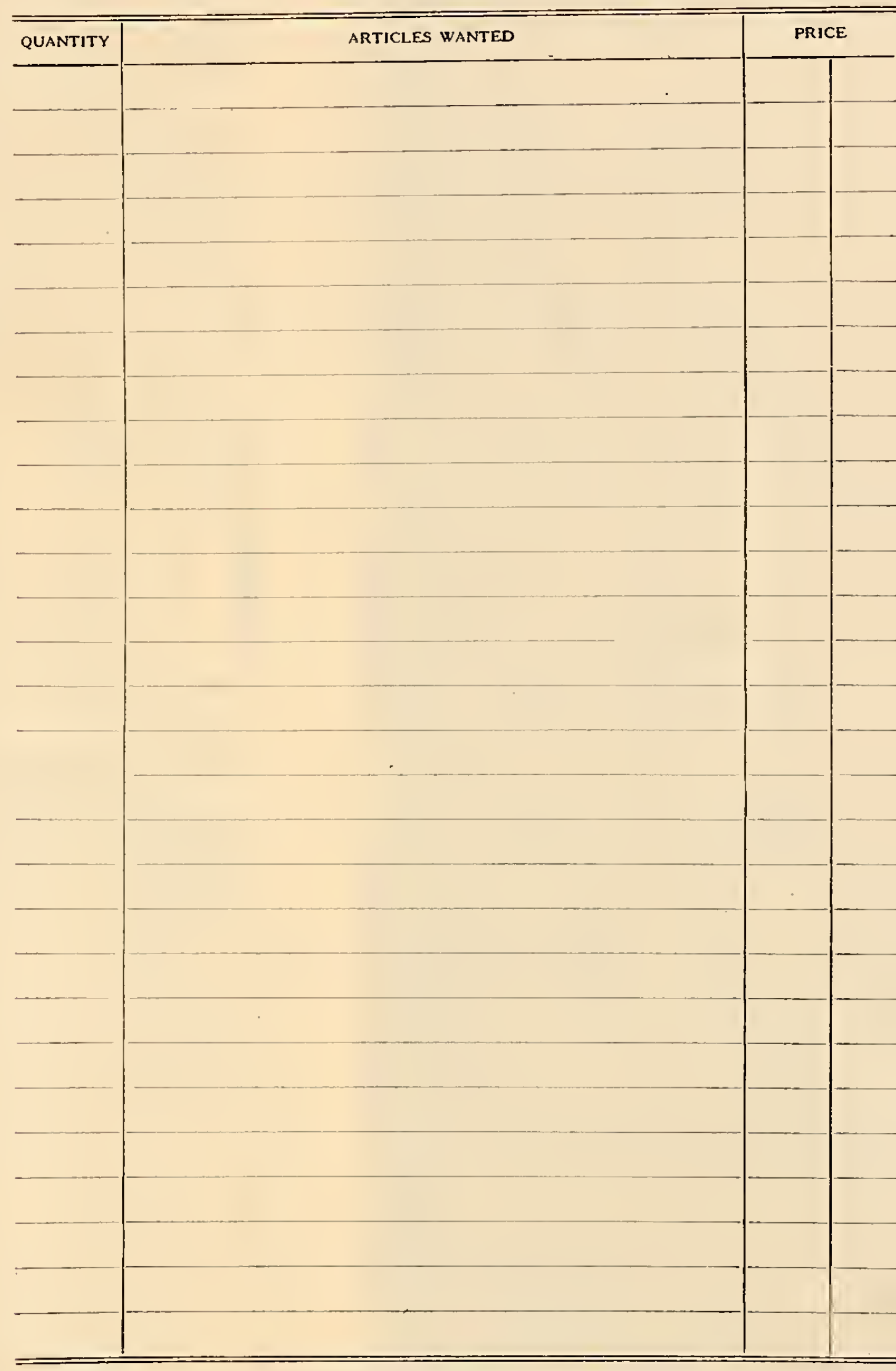


ORDER SHEET. STUMPP \& WALTER CO. 204-206 North Eutaw Street, BALTIMORE, MARYLAND
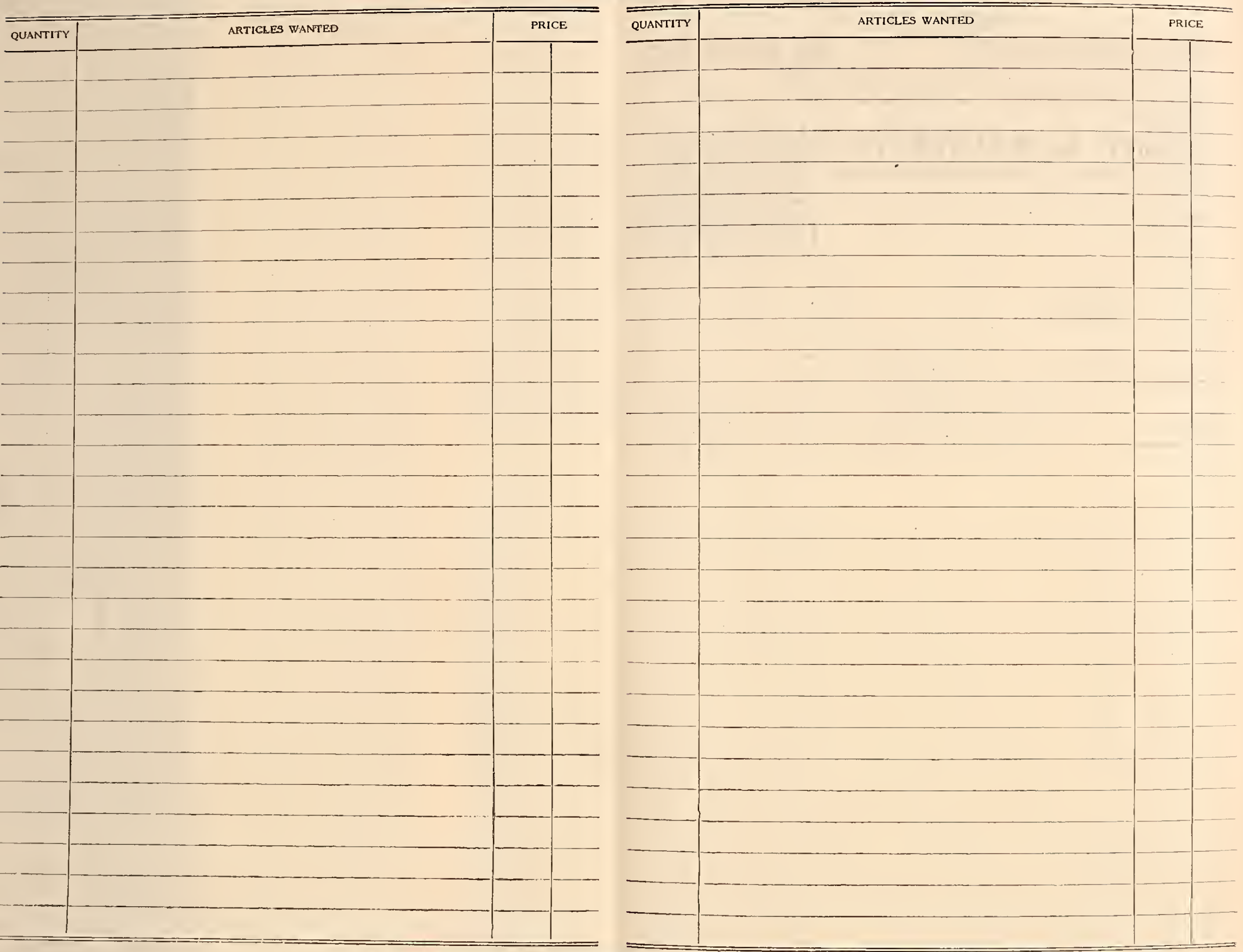


\section{Famous "Garden Full" Collections}
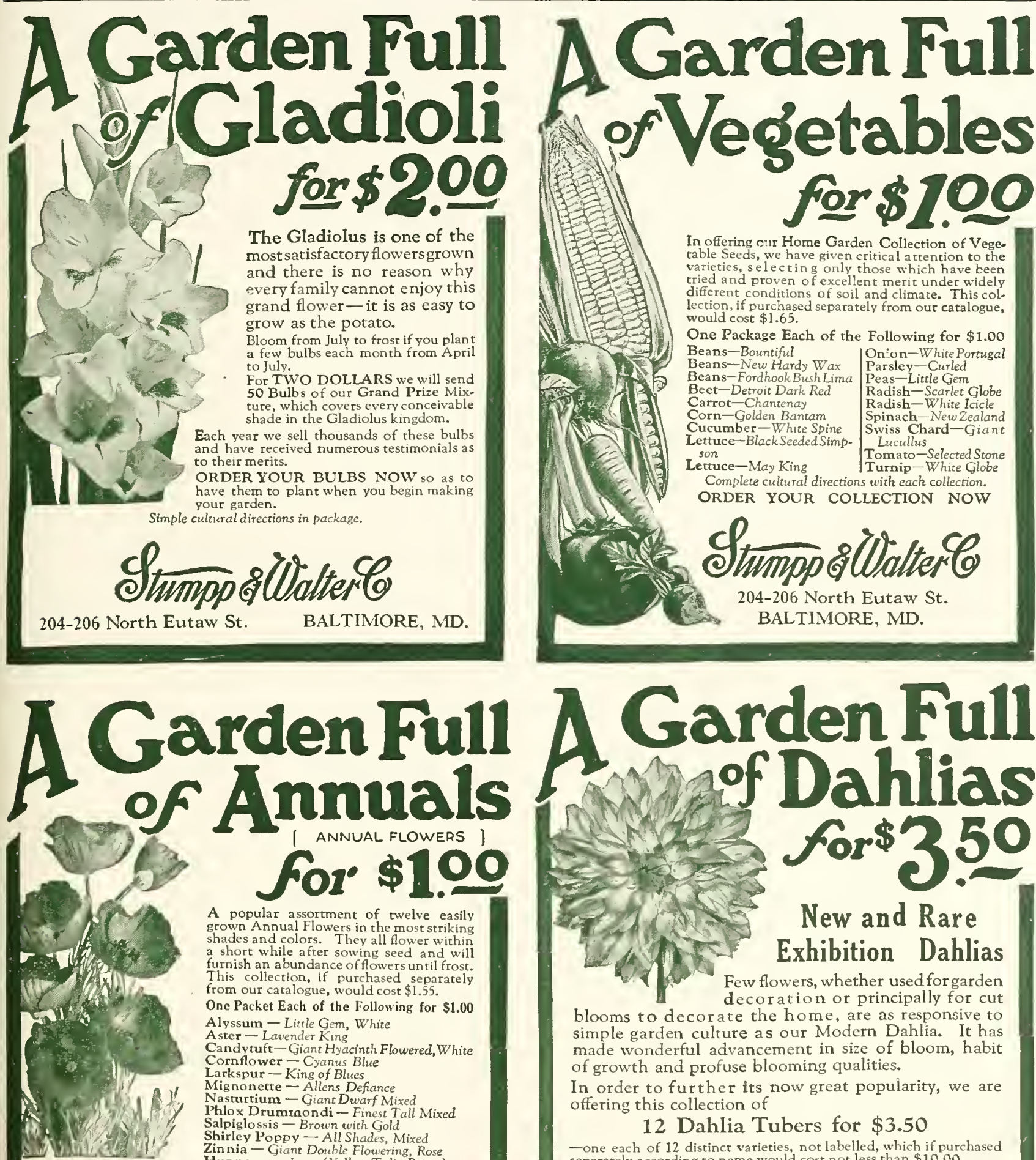

A popular assortment of twelve easily grown Annual Flowers in the most striking shades and colors. They all flower within a short while after sowing seed and will furnish an abundance of flowers until frost. This collection, if purchased separatel our catalogue, would cost $\$ 1.55$.

One Packet Each of the Following for $\$ 1.00$ Alyssum - Little Gem, White

Aster - Lavender King

Condytuft-Giant Hyacinth Cornflower - Cyanus Blue

Mignonette - Allens Defiance

Nasturtium - Giant Dwarf Mixe

Phlox Drumnondi - Finest Tall Mixed

Salpiglossis - Brown with Gold

Shirley Poppy - All Shades, Mixed

Zinnia - Giant Double Flowering, Rose

Simple Hunnemannia - (Yellow Tulip Poppy)

ORDER YOUR COLLECTION NOW

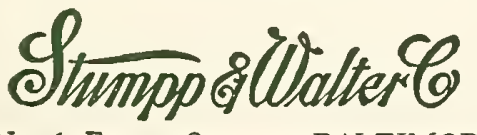

204-206 North Eutaw St.

BALTIMORE, MD.

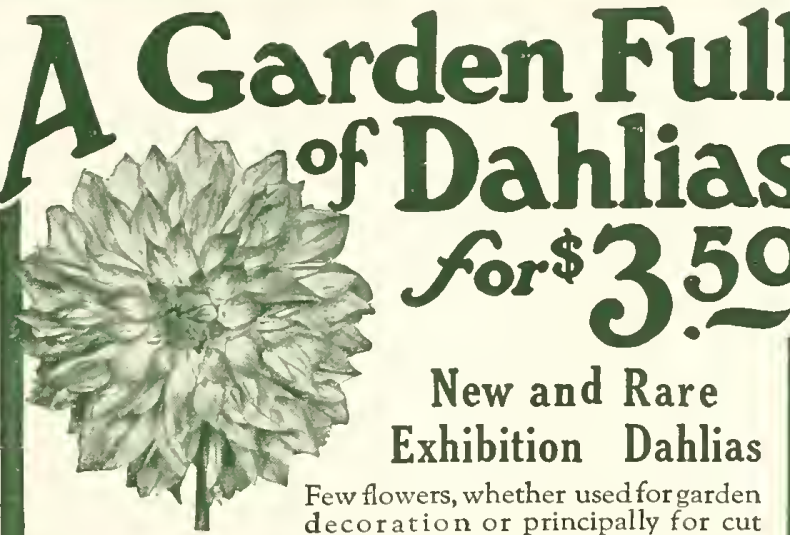
blooms to decorate the home, are as responsive to simple garden culture as our Modern Dahlia. It has made wonderful advancement in size of bloom, habit of growth and profuse blooming qualities.

In order to further its now great popularity, we are offering this collection of

12 Dahlia Tubers for $\$ 3.50$

-one each of 12 distinct varieties, not labelled, which if purchased separately according to name would cost not less than $\$ 10.00$.

Order Your Tubers Now so as to have them ready to plant any time after the tenth of May or when all danger of frost is past.

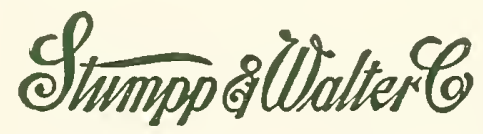

204-206 North Eutaw St.

BALTIMORE, MD. 


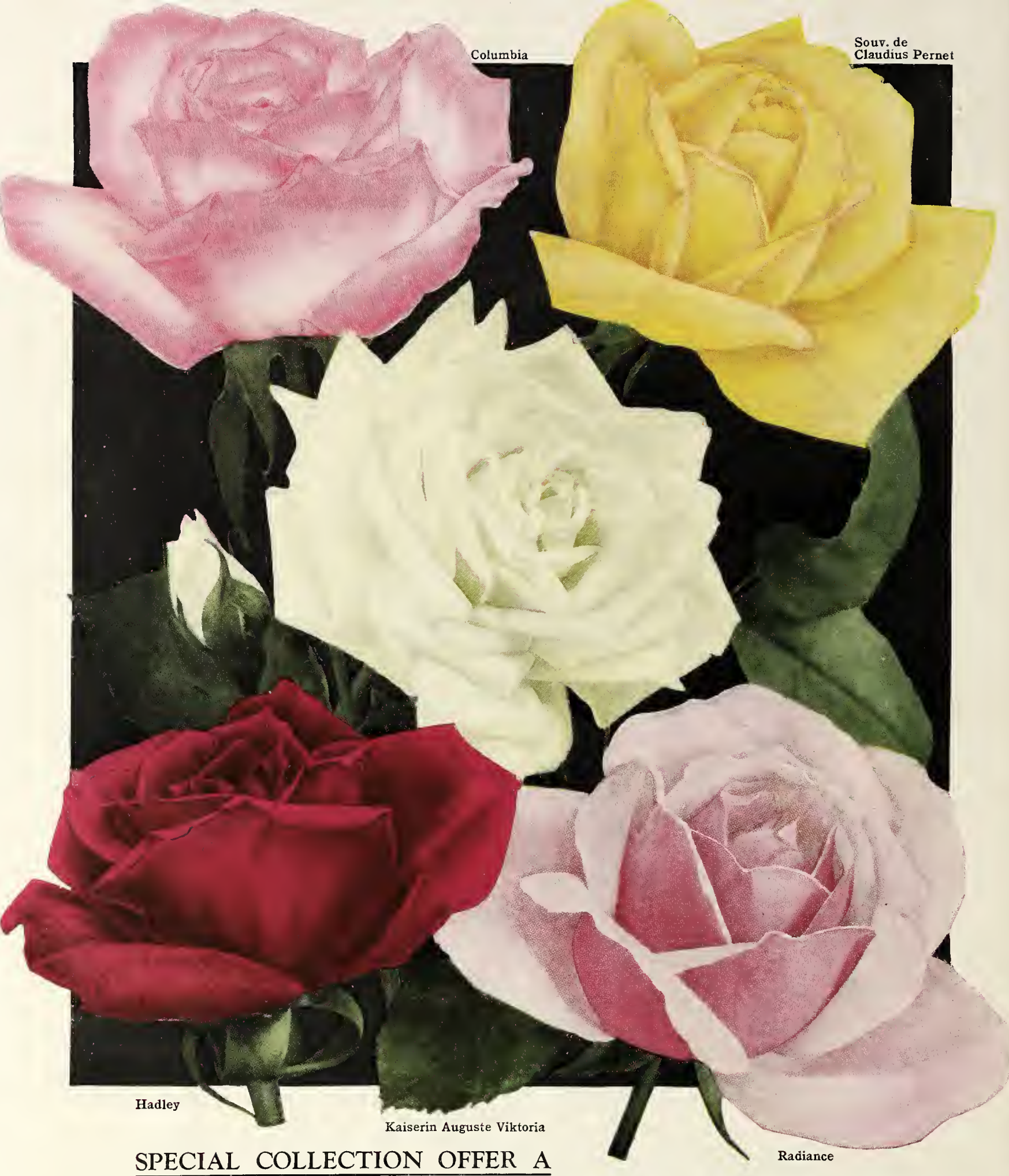

Five Fine Everblooming Rose Bushes. Plants from 6-inch pots at $\$ 1$ each, $\$ 11$ per dozen Souv. de Claudius Pernet Radiance Kaiserin Auguste Viktoria Columbia Hadley

\section{STUMPP \& WALTER CO.}

204-206 North Eutaw Street $\sim$ BALTIMORE, MARYLAND 